\title{
Taxonomic revision and paleoecology of Middle Devonian (Eifelian) fishes of the Onondaga, Columbus and Delaware limestones of the eastern United States
}

\author{
Robert Lewis Martin \\ West Virginia University
}

Follow this and additional works at: https://researchrepository.wvu.edu/etd

\author{
Recommended Citation \\ Martin, Robert Lewis, "Taxonomic revision and paleoecology of Middle Devonian (Eifelian) fishes of the \\ Onondaga, Columbus and Delaware limestones of the eastern United States" (2002). Graduate Theses, \\ Dissertations, and Problem Reports. 1678. \\ https://researchrepository.wvu.edu/etd/1678
}

This Dissertation is protected by copyright and/or related rights. It has been brought to you by the The Research Repository @ WVU with permission from the rights-holder(s). You are free to use this Dissertation in any way that is permitted by the copyright and related rights legislation that applies to your use. For other uses you must obtain permission from the rights-holder(s) directly, unless additional rights are indicated by a Creative Commons license in the record and/ or on the work itself. This Dissertation has been accepted for inclusion in WVU Graduate Theses, Dissertations, and Problem Reports collection by an authorized administrator of The Research Repository @ WVU. For more information, please contact researchrepository@mail.wvu.edu. 
Taxonomic Revision and Paleoecology of Middle Devonian (Eifelian) Fishes

of the Onondaga, Columbus and Delaware Limestones of the eastern United States.

\author{
Robert L. Martin \\ Dissertation submitted to the \\ College of Arts and Sciences \\ at West Virginia University \\ in partial fulfillment of the requirements \\ for the degree of \\ Doctor of Philosophy \\ in Geology \\ Thomas Kammer, Ph.D. Chair \\ Robert Behling, Ph.D. \\ Robert Carr, Ph.D., Ohio University \\ Steven Kite, Ph.D. \\ Richard Smosna, Ph.D. \\ Department of Geology
}

Morgantown, West Virginia

2002

Keywords: Eifelian, fishes, ptyctodont, Deinodus, Onondaga 


\begin{abstract}
Taxonomic Revision and Paleoecology of Middle Devonian (Eifelian) Fishes of the Onondaga, Columbus and Delaware Limestones of the eastern United States.
\end{abstract}

\title{
Robert L Martin
}

The Eifelian stage of eastern North America has produced the remains of a substantial number of fish taxa, mostly from the Onondaga Limestone of New York and the Columbus and Delaware limestones of Ohio. Fish specimens in rock matrix from the Buffalo Science Museum and the Cleveland Museum of Natural History were compared to rock samples taken from quarries in Cheektowaga, New York and Warrensburg, Ohio, in order to determine the units from which the fish specimens originally came. This method allowed reasonable inference into the provenance of the museum specimens.

The stratigraphy indicates that the seas of New York and Ohio were deepening throughout the Eifelian, terminating in the dark shale beds of the Givetian stage. The rock units of both areas are characterized by a series of aggradations and inundation events.

Of the 41 taxa of fish originally found in the two museums, only nine are considered valid as a result of this study. Macropetalichthys sullivanti was a benthic dweller found in the deeper units of the upper Moorehouse and Seneca members of the Onondaga Formation and the Delaware Limestone as well as the shallower units of the upper Columbus. $M$. rapheidolabis is considered a junior synonym of $M$. sullivanti.

Palaeomylus and Ptyctodus were both durophagous fishes that probably stayed near the bottom of the sea. Ptyctodus was found only in the upper Moorehouse, but Palaeomylus was found in the upper Columbus, Delaware and the upper Moorehouse. Rhynchodus was found in the same units, but was a predator with shearing dentition.

Deinodus bennetti was a common element of the upper Moorehouse and was a ptyctodont. It is likely, based on dental elements in the Buffalo Museum of Science, that $D$. bennetti was durophagous. Deinodus ohioensis, n. sp., a shallow water fish very similar to $D$. bennetti is formally described. Little can be theorized about its feeding strategy because most of the dental elements studied were imbedded in matrix.

Onychodus and Machaeracanthus were large, mobile predators that moved in and out of deeper waters, perhaps into shallow waters to feed. Both possess large tooth whorls and elongate jaws. Machaeracanthus is formally placed in the family, Ischnacanthidae, based on these whorls and Machaeracanthus major is considered a junior synonym of M. peracutus. 


\section{ACKNOWLEDGEMENTS}

One must always begin acknowledgements by thanking their parents. Mine have been very supportive and never hesitated when I came to the conclusion that I would need still more schooling. I thank them for their understanding, interest and support..

No research project could be completed without assistance, and I certainly exploited mine. I would like to thank the following museum collection managers and quarry managers: Dr. Richard Laub of the Buffalo Museum of Science, Gary Jackson and Dr. Michael Williams of the Cleveland Museum of Natural History, Ron Hope of the Buffalo Crushed Stone Quarry in Cheektowaga, New York, Danny Workman of the Martin Marietta Quarry, the Martin Marietta office in Xenia, Ohio and Martin Jones of the Wagner Quarry in Sandusky, Ohio.

The completion of the dissertation went as smoothly as possible thanks to my wonderful committee. Dr. Thomas Kammer, my advisor, set the project in motion and helped me throughout the entire time with logistics, protocol and critique. Dr. Richard Smosna helped to hash out the sedimentological aspects of the work, a much stronger component of the dissertation that I had originally expected it to be. Dr. Robert Carr solidified the taxonomy and nomenclature of the fish sections. Dr. Steven Kite, editor extraordinaire, made certain that the tome flowed well and corrected innumerable grammatical mistakes. Dr. Robert Behling, who I think knows everything about everything, was invaluable in working out the methods for the project.

Without a supporting staff, no university department could progress. I would like to thank Donna Titus for her help in everything from registration to paychecks. Hope Stewart was always there for advise and help in departmental matters and kept the department running smoothly. Randy Crowe was constantly repairing my computer account and helping me with page set-ups, printer problems, etc. Without him, I would still be working on logging in.

Above all, I'd like to thank my wife, Nancy, who supported me (mentally, emotionally, and financially) from the onset of this degree to (thankfully) its completion. She certainly made the experience much more pleasant and worthwhile. 
Table of Contents

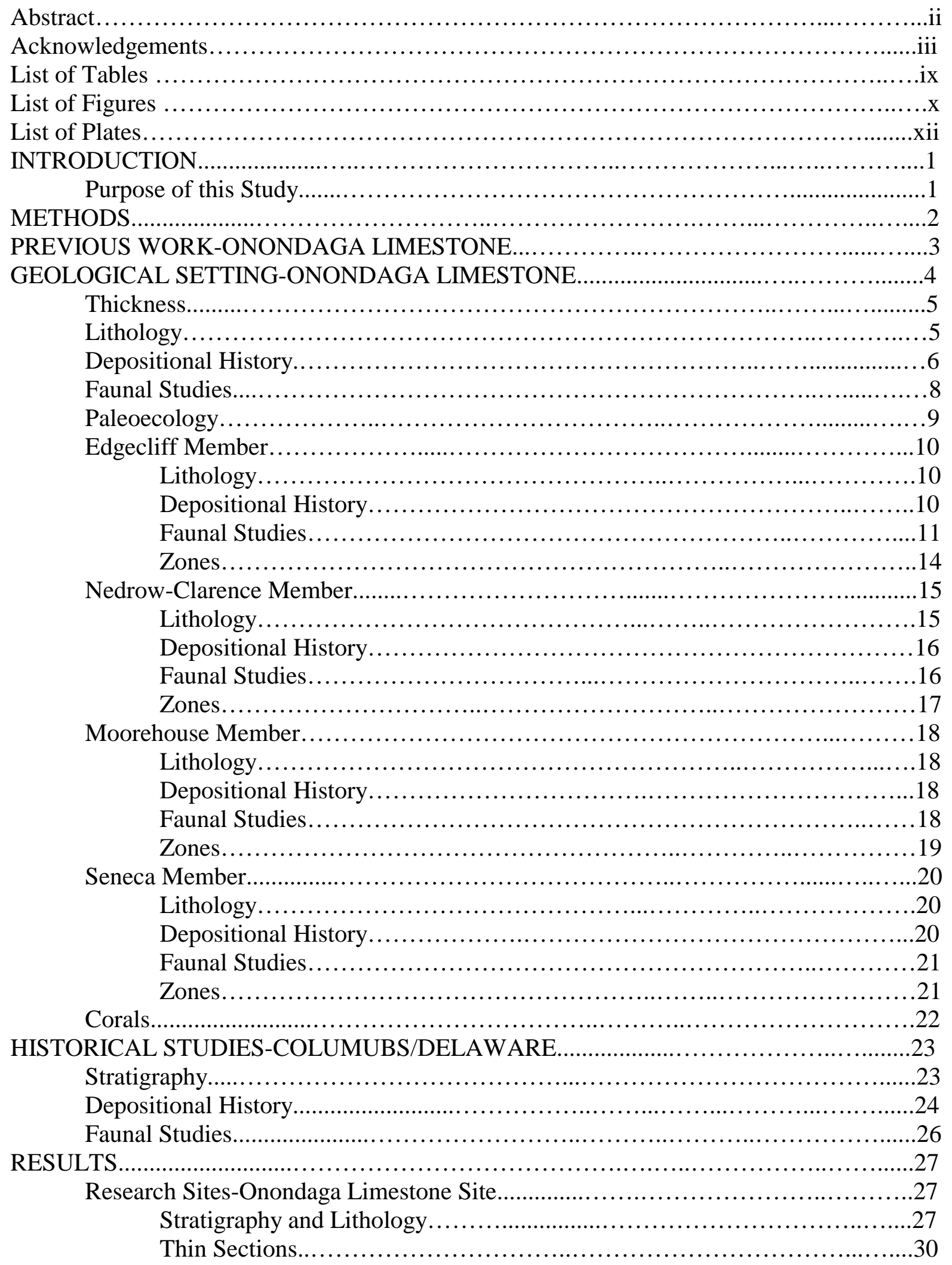


Research Sites-Columbus Limestone Site......................................... 31

Stratigraphy and Lithology............................................... 31

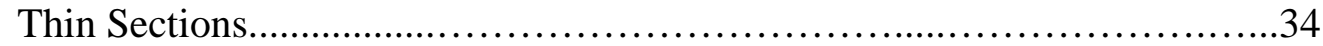

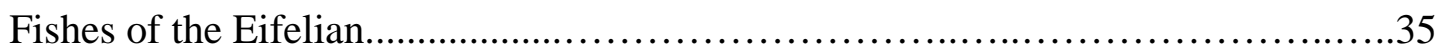

Classification of Eifelian Fishes.........................................36

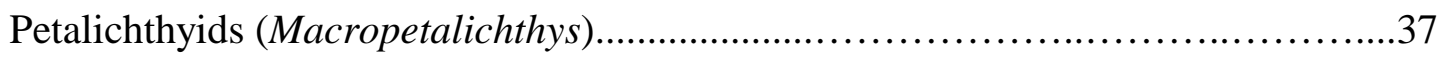

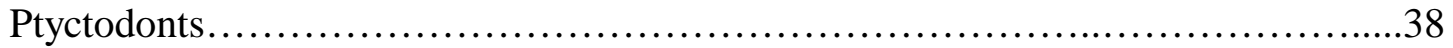

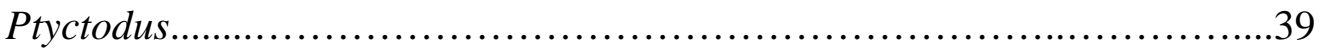

Palaeomylus .............................................................40

Rhynchodus.......................................................40

Deinodus............................................................. 42

Eczematolepis......................................................46

Asterosteus.............................................................47

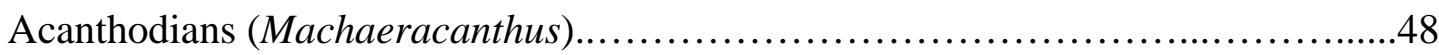

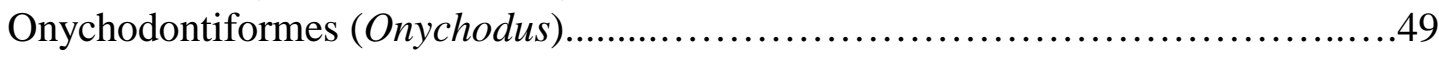

Improperly Identified or Unidentified Specimens.............................50

Valid genera assigned to incorrect specimens..........................50

Unknown genera..................................................... 51

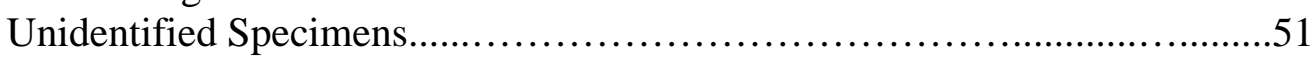

Formal description of Deinodus ohioensis..................................52

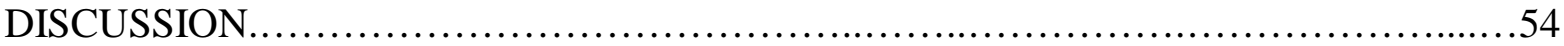

Columbus and Delaware Limestones............................................54

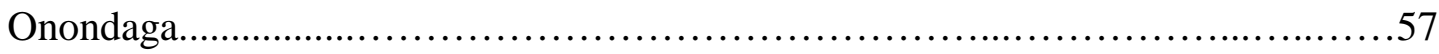

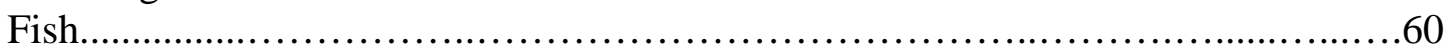

CONCLUSIONS............................................................61

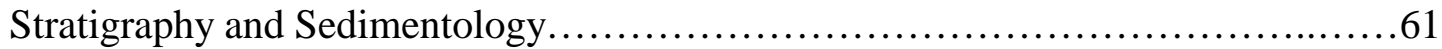

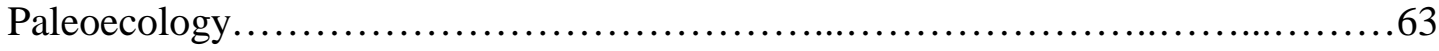

Inferences Based on Depositional Environments......................63

Functional Morphology...........................................64

Comparisons with other Fish Faunas.................................64

Taxonomic Revisions..............................................65

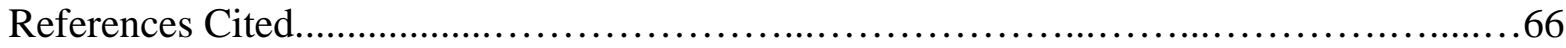

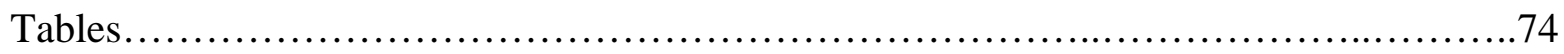

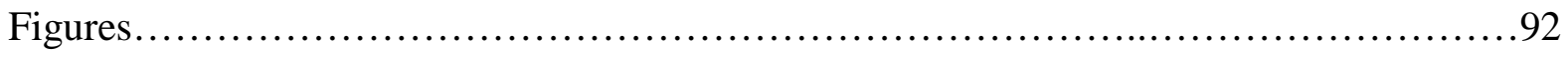

Plates........................................................................ 111

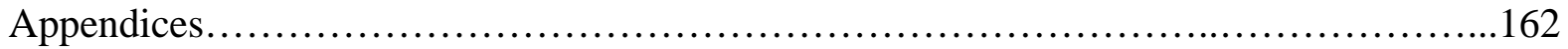


List of Tables

Table 1: Biozones of Oliver (1954) and Feldman (1985) in western New York germane to this study. ..........................................................74

Table 2: Thin sections taken from various locations through the Columbus and Onondaga limestones............................................................ 80

Table 3: Specimens of the Buffalo museum that have been assigned to the correct taxon or identified to function. ..............................................82

Table 4: Specimens of the Cleveland Museum of Natural History that have been assigned to the correct taxon or identified to function. .85

Table 5: The occurrence of fish taxa, and their trophic modes, within the members of the Onondaga, Columbus and Delaware limestones and a list of valid specimens, including those taxa that have been reclassified...........................89

Table 6: The occurrence of fish taxa and their trophic modes within the members of the Onondaga, Columbus and Delaware limestones..........................91 


\section{List of Figures}

Figure 1A: Outcrop belt of the Eifelian in New York and Ohio (Rickard, 1984).... . . .92 Figure 2: Stratigraphic section of the Onondaga Formation at the Cheektowaga Quarry near

Buffalo, New York.. . . . . . . . . . .......................................... .93

Figure 3A: Time divisions proposed for the Eifelian..............................94

Figure 4: Paleogeography of the Eifelian (Scotese, 2002) . . . . . . . . . . . . . . 95

Figure 5: Depositional environments of the Onondaga Formation, from eastern New York to the Buffalo area in western New York.........................................96

Figure 6: Stratigraphic sections of the Columbus and Delaware Limestones at the

Warrensburg Quarry near Delaware, Ohio, and the Martin Marietta Quarry in

Sandusky, Ohio.

Figure 7: Stratigraphic column of Oliver (1954; Figure 2, modified) and the biozones within

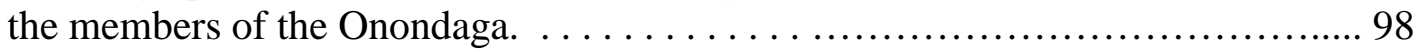

Figure 8A: Wells' (1947, Figure 1) identification of the location of bone beds within the

Columbus and Delaware Limestones in central Ohio.. . . . . ........... . . . . . 999

Figure 9A: Location of the Cheektowaga Quarry in the southwestern section of the USGS

Lancaster 7.5' Quadrangle south of the town of Cheektowaga, New York.... . . . . 100

Figure 10: Members of the Onondaga Formation exposed at the Cheektowaga Quarry... 101

Figure 11A: Terraces at the Cheektowaga Quarry approximate member boundaries.. . . . 102

Figure 12A Megaripples exposed on the floor bottom of the Cheektowaga Quarry. ...... 103

Figure 13: Calcareous algae found within the upper units of the Clarence Member.. . . . .104

Figure 14A-C: Coral bed within the lower Columbus Limestone at the Warrensburg

Quarry............................................................. 105

Figure 15: Stromatoporoids from the Warrensburg Quarry......................... 106

Figure 16: Stratigraphic section of Leonard (1996; Figure 5) from outcrops in southern

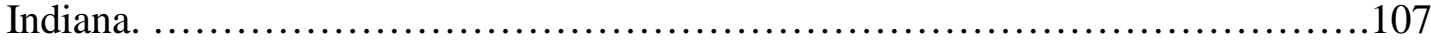

Figure 17: Thin sections of the units of the Columbus Limestone at the Warrensburg Quarry........................................................... 108

Figure 18: Recent cladogram showing the modern theory of placoderm interrelationships

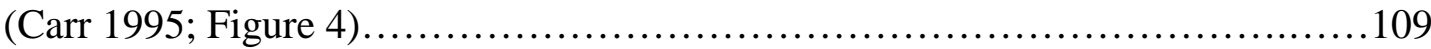

Figure 19: Dimensions of a ptyctodont dental element as described in the text............110 


\section{List of Plates}

Plate 1: Macropetalichthys sullivanti Norwood and Owen (1846). . . . . . . . . . . .112

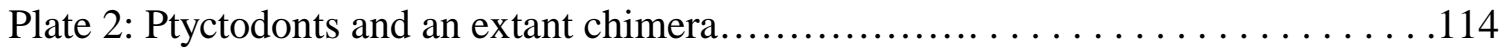

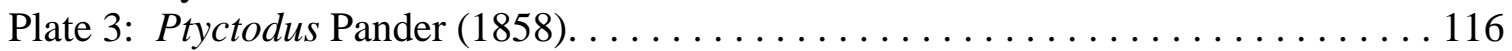

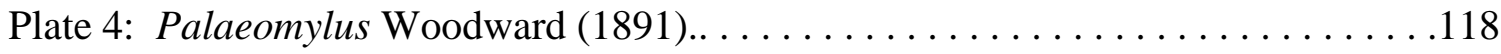

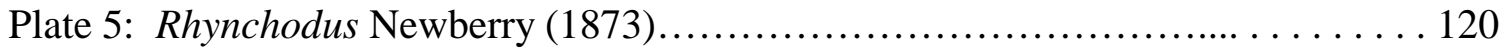

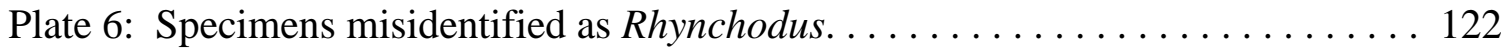

Plate 7: Deinodus bennetti Hussakof and Bryant (1919). . . . . . . . . . . . . . . 124

Plate 8: Deinodus bennetti Hussakof and Bryant (1919).. . . . . . . . . . . . . . . . 126

Plate 9: Deinodus bennetti Hussakof and Bryant (1919). . . . . . . . . . . . . . . . 128

Plate 10: Deinodus bennetti Hussakof and Bryant (1919).. . . . . . . . . . . . . . . . . 130

Plate 11: Deinodus bennetti Hussakof and Bryant (1919). . . . . . . . . . . . . . . 132

Plate 12: Deinodus bennetti Hussakof and Bryant (1919) cranium.. . . . . . . . . . . 134

Plate 13: Deinodus ohioensis Martin (n. sp.)............................. 136

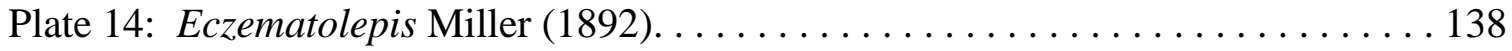

Plate 15: Specimens misidentified as Asterosteus Newberry (1875) . . . . . . . . . . . 140

Plate 16: Machaeracanthus Newberry (1857). . . . . . . . . . . . . . . . . . . 142

Plate 17: Onychodus sigmoides Newberry (1857). . . . . . . . . . . . . . . . . 144

Plate 18: Onychodus sigmoides Newberry (1857) . . . . . . . . . . . . . . . . . 146

Plate 19: Onychodus sigmoides Newberry (1857) . . . . . . . . . . . . . . . . . . . 148

Plate 20: Unknown or previously identified incorrect genera. . . . . . . . . . 150

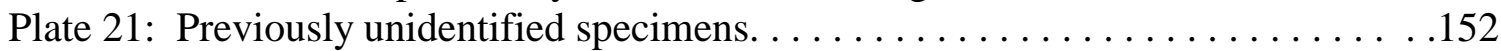

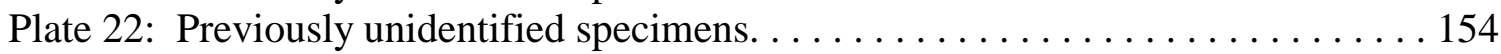

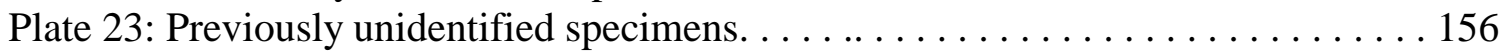

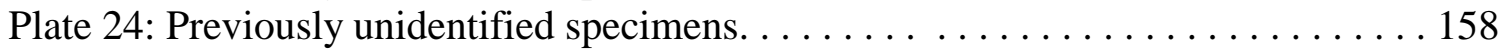

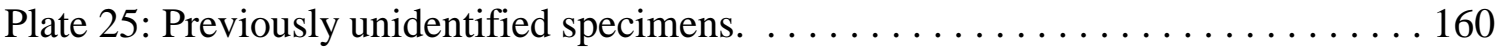




\section{INTRODUCTION}

The Onondaga Formation is a limestone of variable lithology of Eifelian (Middle Devonian) age that crops out from southeastern New York, north to Albany, and westward across the state and into Ontario (Figure 1A). It is visible in roadcuts, but better exposures exist in quarries. Much of the literature pertaining to the formation centers on the faunal components, particularly corals and brachiopods, both of which are numerous and characteristic of certain units (e.g. Oliver, 1954, 1956b; Feldman, 1980; Friedman, 1985).

The equivalent Columbus Limestone has less terriginous mud than the Onondaga Formation. It crops out just southwest of Columbus, Ohio, and extends northward to Sandusky, Ohio, and across Lake Erie into Ontario, Canada (Figure 1A). Due to the lack of significant relief in central Ohio, nearly all of the outcrops are found in quarries. The faunas of the Columbus Limestone are very similar to that of the Onondaga, though individual species may vary, and stromatoporoids are more common in the Columbus.

The Eifelian-age Delaware Limestone is a formation consisting of lime mud and terriginous clay that rests atop the Columbus. Its type section was inundated during the construction of a city park, and the formation is rarely completely exposed elsewhere. The unit is characterized by a sparse fauna, yet it is famous for its beds of fish bone.

The Onondaga, Columbus, and Delaware formations were deposited on a relatively shallow carbonate shelf. Units of the Onondaga may have been deposited in slightly deeper water as they were located closer to the center of the Appalachian basin (Oliver, 1954; Figure 1B). Vertebrate fossils are not usually considered to be good indicators of freshwater or marine conditions. It is known, however, that vertebrates were most common in the near shore environments of the Devonian and are found in association with typical marine faunas (Blieck et al., 1988).

The Eifelian was the first age in which jawed fishes, particularly the group that makes up the majority of the specimens observed during this study, the ptyctodonts, became common. Fishes descended from Silurian forms evolved rapidly in the Middle Devonian seas, and fish diversity was high. That level of fish diversity would not be reached again until the end of the Cretaceous (Thomson, 1977). The Middle Devonian was the time in which placoderms, particularly ptyctodonts, dominated, and they represent the majority of the vertebrate fauna in most units, worldwide. The placoderms displaced agnathans as the dominant fish group, though they, in turn, would be displaced by the sharks and osteichthyans at the end of the Devonian (Long, 1995). The high diversity is the reason that fishes from the Eifelian of eastern North America were chosen for the present study.

The fishes of the Eifelian of New York and Ohio were collected and described around the turn of the 20th century, but have not been extensively studied until now. Denison (1978, 1979) reviewed the descriptions, and, presumably, at least some of the museum specimens, for the Handbook of Paleoichthyology. He synonymized many of the earlier descriptions and questioned others. In later chapters, this work attempts to fill in some of the gaps left by Denison's reviews.

Purpose of this study

Though a large number of studies have been published on the Onondaga, Columbus and Delaware limestones, very little has been completed on the fish from these units. In 
addition, the Onondaga of western New York has long been ignored. To complicate matters, different stratigraphic studies conducted at a particular site and published during the same period of time may contradict each other (e.g. Gurney and Friedman, 1986; Brett and Ver Straeten, 1995). The lack of corroboration is probably due to the gradational lithology of the units and the high variability of the units from one location to the next. This work is an attempt to ascertain the depositional history of the formations and understand the paleoecology of the fishes that lived within the facies that form the units.

\section{METHODS}

Because large numbers of fossil fishes could not be expected to be collected specifically for this study, museum collections were used. Quarries were used to examine the rock units because a great deal of section is exposed and is easily accessed. Figure 1A shows where the primary quarries (blue arrows) and the museums (red arrows) are located.

The Buffalo Museum of Science has a large and well-maintained collection of Eifelian fishes, most collected by the authors of the type species. Consequently, numerous type specimens are housed there. This collection was used to identify and describe the Onondaga fishes of New York.

The Cleveland Museum of Natural History has an even larger collection of fossil fishes. Most of the specimens were collected from the areas around Marblehead, Sandusky, Delaware and Columbus, Ohio. Unfortunately, many are misidentified or unidentified. When possible, the errors were corrected and unidentified specimens were identified.

The rocks of the Onondaga Formation were examined at the Buffalo Crushed Stone Quarry in Cheektowaga, New York, just outside of Buffalo (Figure 1A). This site will be referred to as the Cheektowaga Quarry for the remainder of the paper. This quarry was chosen because it was the source of most of the Eifelian fossils in the Buffalo Museum of Science. Over 40 meters and all four members of the Onondaga are exposed there. A Garmin GPS III was used to determine the latitude and longitude of the site $\left(42^{\circ} 53\right.$ ' $45^{\prime} \mathrm{N}$, 784 '20” W).

Three quarries were used for examining the Columbus and Delaware limestones. Three sites were necessary because of the change in the lithology of the formations from south to north, and the scarcity of Delaware outcrops. The primary site, the Martin Marietta Delaware Quarry, is located in Warrensburg, just outside of Delaware, Ohio (Figure 1A), and exposes over 30 meters of the Columbus Limestone. This site will be referred to as the Warrensburg Quarry for the remainder of the paper. The secondary site, the Wagner Quarry near Sandusky, Ohio (Figure 1A), contains the Delaware, but a detailed analysis was impossible the quarry manager did not provide the necessary time. Information pertaining to the Delaware was supplemented by historical studies. The Martin Marietta Quarry on the south-side of Columbus, Ohio (Figure 1A), provided additional information, but could not be studied in detail because the work area was destroyed. A Garmin GPS III was used to determine the latitude and longitude of the sites $\left(40^{\circ} 18^{\prime} 00^{\prime} \mathrm{N}, 83^{\circ} 10^{\prime} 30^{\prime}\right.$ W).

At least three trips to each quarry were made to study the rocks in detail. Where there was a major change in the lithology, rock samples were taken for further analysis. Minor changes were examined more closely and some additional sampling occurred. Sedimentary structures were noted, gross morphologies, recorded, and trends in the fauna were observed. 
At least four trips to each of the two museums insured that all of the identifiable specimens were seen. The samples of rock collected in the field were brought to the museums so that the matrixes of the fossils could be compared. By determining the stratigraphic unit from which the fishes were collected, it was possible to reconstruct the benthic paleohabitat of the fishes. Trips to the Field Museum in Chicago, Illinois, and The Ohio State University Geology Collection provided very little additional information on the diversity of the Eifelian fishes of eastern North America.

The rock samples taken where there were major lithological changes were used for thin sections. The thin sections were not intended to provide a detailed study of the outcrops, but were used to accentuate the reconstruction of general trends inferred by macroscopic work.

Each fossil fish specimen was examined to make certain that the original taxonomic and anatomical identification was correct. Each tooth, plate or spine was evaluated in order to ascertain the life habits of the taxon. Specimens were compared to similar forms within the same collection, with specimens from the other museum's collection and with other taxa from Middle Devonian collections. Detailed descriptions of well-preserved, articulated Australian forms were used for comparison in order to identify the North American forms.

Denison's $(1978,1979)$ reviews of placoderms and acanthodians in the Handbook of Paleoichthyology were used as a template in determining which taxa are valid and which are spurious. Whenever possible, the works of the original authors were reviewed, as many of the specimens have not been studied since that time.

Whenever possible, invertebrate taxa associated with museum specimens were identified (see Appendixes 1-4 for invertebrate faunal lists of the units). These data were compared to historical reviews in order to place the specimens within the proper stratigraphic unit. The invertebrate fauna, and the depositional environment of the unit and the anatomy of the fossil fishes were used to understand the feeding strategies and habitat preference of the fishes. However, because faunal diversity remains nearly constant throughout the units, and because there is a scarcity of identifiable shells within the matrixes of the fish specimens, the use of invertebrate taxa to determine vertebrate paleoecology was limited.

\section{PREVIOUS WORK-ONONDAGA LIMESTONE}

The Onondaga Formation was first described by Hall in 1839 for cherty and partially dolomitized limestones in Onondaga County, New York (Dennison, 1961; Warters, 1972; Lindemann, 1989). Though the section was not complete, it did encompass units from the upper part of the Edgecliff Member to the middle of the Seneca Member (Oliver, 1954; Figure 2). In 1881, Boyd (in Dennison, 1961) recognized similar rocks in the central Appalachians and became the first to correlate the Onondaga of New York with rocks of other areas. Kindle (1912) described equivalent rocks in Virginia, West Virginia and Maryland, though that correlation was doubted by Reger in 1924 (1961).

Willard (1936) separated the Selinsgrove Limestone, 22 meters of shaly limestone, from the upper Onondaga in Pennsylvania. Willard (1939) concluded that the Selinsgrove graded laterally into the Needmore shale, a limey shale (Newton, 1979; Hasson and Dennison, 1988). Woodward (1943) divided the Onondaga into a shale unit, the Needmore shale, a chert unit, the Huntersville chert, and a limestone unit. He concluded that the limestone unit was not the Selinsgrove and called it the Onondaga. Early surveys of the New 
York Geological Survey (New York State Geological Society, 1931) referred to the cherty portion of the Onondaga as the Corniferous and the limestone portion as the Seneca.

The Onondaga was originally placed in the Helderberg Group (Lockhovian). Boyd (1881) referred to the rocks that he described as being the same age as the Corniferous Limestone of the Upper Helderberg Group. The term Corniferous, or Cornitiferous, refers to the Onondaga as described by Eaton (1828, in Oliver, 1954) and was still used extensively for some time after Hall's Onondaga was accepted (Dennison, 1961).

Cooper and others (1942) and Dutro (1981) placed the Onondaga at the top of the Onesquethaw Stage (Figure 3A) with the Esopus and Schoharie formations below. The Tioga Bentonite, a volcanic ash layer (Swain and Rogers, 1966), was used to separate the Onesquethaw from the overlying Hamilton Formation (Dennison, 1961). In contrast, Schuchert (1943) used the term Ulsterian to embrace the Esopus, Schoharie, and Onondaga formations.

Rickard (1981) divided the Erian Series into four stages. The Southwood Stage comprised the Onondaga up to the Tioga Bentonite. He had previously (1964, in Koch, 1981) placed the Emsian-age Schoharie and Esopus, and their equivalents, in the Sawkill Stage limiting the Southwood Stage to the Onondaga and its equivalents. The Correlation of Stratigraphic Units of North America (COSUNA) Project (Patchen et al., 1985) retains the Onondaga within the Southwoodian Stage of the Erian Series.

Today, the Onondaga is considered Eifelian in age (e.g., Oliver, 1976; Friedman, 1985; Feldman, 1994). Most of the older nomenclature has been abandoned in favor of the chronological divisions recognized by Oliver (1954a, see below). The Eifelian ranges from 380 million years ago to 391 million years ago (Geological Society of America, 1999).

\section{GEOLOGICAL SETTING - ONONDAGA LIMESTONE}

The depositional history of the Onondaga has been interpreted differently by several authors. Due to a lack of algae and stromatoporoids, some thought it was deposited in deep water (Wolosz, 1995a). Others thought it to be a shallowing sequence due to subaerial exposure evident on the tops of some bioherms (Wolosz, 1995). Others thought the erosion to be the end of a shallowing cycle and the beginning of a transgression (Oliver, 1956a). A reevaluation of depositional features may help to resolve many of these issues.

The first divisions of the Onondaga came prior to its formal description. Vanuxem (in Oliver, 1954) was among the first to divide the Onondaga into four sections. However, two years earlier, Conrad (in Oliver, 1954) identifies only two divisions. Such variance in interpretation was probably one of the reasons why there was so much variation in the naming and placement of the Onondaga and its members (Oliver, 1954).

In eastern New York, the formation can be consistently divided into members only based on paleontology (Wolosz and Paquette, 1988). Farther west, lithological differences are more distinct. The accepted division of the Onondaga into members began with Oliver (1954; Figure 2). The Edgecliff was named for a unit near Edge Park, just southwest of Syracuse. The Nedrow was described in a Native-American reservation quarry just south of the town that bears its name. In western New York, the Nedrow changes laterally into the Clarence (Koch, 1981). The name Moorehouse comes from a unit within the Jamesville Quarry known as the Moorehouse Flats. The Seneca was named by Vanuxem in 1839 for rocks found in Seneca County (Oliver, 1956a). 
Thickness

The Eifelian of the northeastern United States ranges in thickness from about 75 meters (Feldman, 1985) in the Allegheny province of New York to about 25 meters in the Ohio Valley (Prosser et al., 1913). The discrepancy is due to a rapid accumulation of terriginous sediments in the east. In central New York, it is about 20 meters in thickness, but thickens to about 75 meters in the eastern and western parts of the state (Rickard, 1981; Feldman, 1985; Wolosz and Paquette, 1988; Van Tyne, 1996). In the subsurface, the formation thins (New York State Geological Society, 1931) toward small pinnacle reefs in southeastern New York to a thickness of about 15 meters, though the reefs may be considerably thicker. Further to the southeast, into Pennsylvania, it again thickens (Mesolella, 1978).

The thicknesses of the individual members in eastern New York vary extensively with locations and the interpretations of various authors. In general, the Clarence-Nedrow, Moorehouse, and Seneca Members are thicker in the west, though the Edgecliff is thinner (Dennison, 1961, Wolosz and Paquette, 1988). However, different authors report very different thicknesses in the same area. Part of this discrepancy could be due to the fact that much of the data were collected in the eastern third of the state where the upper Onondaga is largely undifferentiated (Dennison, 1961). Some authors refer to the units in eastern New York as the Edgecliff and the middle and upper Onondaga (Oliver, 1954). Further confusion could have resulted from the fact that the similarities between the members led various authors to define member boundaries at different positions in the formation.

In eastern New York, Oliver (1956) observed about 8 meters of Edgecliff, 3-5 meters of Nedrow, 25 meters of Moorehouse and 7-8 meters of Seneca for a total of 43-46 meters. Wolosz and Paquette (1988) recorded 43 meters of Onondaga in the Buffalo area. A bit further east, Feldman (1994) reported about 5 meters of Edgecliff, 12 meters of Clarence, 12 meters of Nedrow, 11 meters of Moorehouse and about 4 meters of Seneca (total=44 meters). This report is one of the only reports estimating the thicknesses of the individual members in western New York.

Most authors report similar thicknesses for all four members in the central part of the state. The New York State Geological Society (1931) and Oliver (1956b) observed about 6 meters of Edgecliff, 5 meters of Nedrow, 8 meters of Moorehouse and 5 meters of Seneca (total=24 meters). Likewise, Oliver $(1954 ; 1956$ a) found 5 meters of Nedrow and 8 meters of Moorehouse, and reported a total section of 20 meters in the central area. At the Cheektowaga Quarry, the Clarence was 17.7 meters in thickness, the Moorehouse, 20 meters, and the Seneca, 3 meters. The Edgecliff formed the floor and could not be measured.

Lithology

The lithologies of the members of the Onondaga are not so disputed. Fine-grained calcite, 5-15 microns in size, dominates the rocks of the Onondaga where fossil material represents less than 50 percent of the rock. Though the term "calcisiltite" was often used to describe those units in prior studies, the rocks shall be referred to as wackestones in this study. The source of the carbonate silt is the disintegration of skeletal material, probably crinoids, corals, brachiopods and, especially, bryozoans (Lindholm, 1969b). Cavities, formed by dissolution or burrowing, may be filled with this fine material. Where there are 
greater concentrations of fossil material, sparry cement may be present. These units shall be referred to as packstones or grainstones rather than the antiquated "calcarenite". Crossbedding is visible in some of these units (Lindholm, 1969b).

Discrete burrows are most common in the outcrop belt of central New York, though similar features in the east and west were probably lost due to bioturbation. The burrows are small, a few millimeters in diameter, usually branching and are oriented parallel to bedding. Bioturbation may account for the scarcity of sedimentary structures in the Onondaga (Lindholm, 1969b). Burrows in the Buffalo area are infilled with chert.

Oliver (1954) identified three types of chert within the Onondaga of eastern New York, dark chert, light chert and a chert associated with faunal components. A dark chert containing gastropods is limited to the Moorehouse and Seneca of the central region. In the deeper areas of the central basin, gastropods flourished and these gastropods are associated with the chert. Numerous spicules and diatoms indicate that an influx of terrestrial silica resulted in a bloom of siliceous organisms. The other two types of chert, dark and light, are largely barren. The color of the chert is often linked to the color of the limestone (Oliver, 1956a).

Bruner and Smosna (2002) found sponge reefs in the subsurface Onondaga of Pennsylvania that closely resembled sponges of the Huntersville Chert, a unit of biogenic origin that is correlative with the Onondaga (Patchen et al., 1985). These reefs consisted of small sponges (appearing as nodules) bound together and containing spicules. Though no spicules were found during the present study, it seems likely that the original source of the chert was siliceous sponges.

\section{Depositional History}

During the Eifelian (391-380 mya), the New York area was located in an epeiric sea in the southern hemisphere, probably around 35 degrees south latitude (Kent and Opdyke, 1977; Kent, 1979; Scotese, 2002; Figure 4). The deposition of the Onondaga began to form after a major regression caused the widespread unconformity at the base of most of the formation (Wolosz and Paquette, 1988). The presence of rounded, green glauconite grains indicates a period of nondeposition, chemical deposition, and sediment reworking prior to the deposition of the Onondaga (Gurney and Friedman, 1986; Wolosz, 1992).

The subsequent transgression moved from eastern New York to western New York. This migration is marked by the Springvale Sandstone (Mesolella, 1966), a basal layer that may be over a meter in thickness (Oliver, 1954) and rests conformably on the Schoharie in eastern New York (Oliver, 1956a; Lindholm, 1969b; Lindemann, 1989). The sand is probably reworked Oriskany (Oliver, 1954) and contains clasts from subjacent units (Lindemann, 1989). Faunal constituents are the same as those found in the Onondaga (Oliver, 1954). A westward transgression is evidenced by the fact that Onondaga rocks rest on progressively older rocks westward (Friedman, 1985), a basal conglomerate occurs at certain locations (Kindle, 1913, in Dennison, 1961), and the shales overlying the Onondaga were likewise deposited earlier in the east than in the west (Oliver, 1954).

In the eastern and western areas of New York, the Tioga Bentonite separates the Moorehouse and Seneca Members. However, in the central area, the ash layer is actually in the Marcellus Shale (Koch, 1981). This indicates that the contact between the Marcellus and 
Onondaga is younger in the western and eastern regions (Oliver, 1956a).

Either during or shortly after the Onondaga transgression, the axis of the Appalachian Basin shifted from eastern New York westward (Lindholm, 1969b) so that it was located over central New York. The shift resulted in the deposition of thin sediments throughout the Eifelian of central New York, i.e., the basin center was starved of sediments (Wolosz and Paquette, 1988). The basin deepened further into Pennsylvania and West Virginia (Swain and Rogers, 1966).

The geographic distribution of the Onondaga fauna suggests that water depth, a product of the local rate of subsidence and isostacy, controlled faunal growth rates and patterns (Oliver, 1954). The basin was surrounded on the north, northeast and west by a broad carbonate shelf, and reefs formed on the edges of the shelf (Koch, 1981). Corals and crinoids were components of the shallow, well-agitated areas, and gastropods and brachiopods preferred the deeper, muddier areas (Oliver, 1954). Sediments are thicker in those areas where biological build-ups exist (Koch, 1981). Water depth controlled cycles of reef growth so that the western and eastern margins of the basin, where waters were shallower and turbulence was highest, developed thick sequences (Wolosz and Paquette, 1988). These areas were shallow shelf environments (Swartz and Swain, 1941) as evidenced by the abundance and diversity of fossils (Lindholm, 1969b). The shelf was wide and subjected to wave agitation, an ideal habitat for large numbers of sessile corals and crinoids to develop (Oliver, 1956a). The appearance of the reefs depended upon the prevailing current, bioerosion and the associated taxa (Williams, 1980).

Brett and Ver Straeten (1995) provided one of the most detailed and complex descriptions of the Onondaga depositional system. They observed two third-order depositional cycles within the Buttermilk Falls and Selinsgrove Formations in Pennsylvania. These two formations were deposited during a period of quiescence between the first two tectophases of the Acadian Orogeny and are coeval with the Onondaga. The transgressive systems tract (TST) of the first cycle is apparent in the Edgecliff and Nedrow of central New York. In addition, nine smaller-scale cycles can be recognized within the two members. Widespread black shales atop the Nedrow may represent the maximum flooding surface (MFS) of the first cycle. A series of eight-to-ten small scale cycles that shallow upward through the lower-middle sections of the Moorehouse represent the highstand systems tract of Cycle 1 (Brett and Ver Straeten, 1995). Small-scale cycles may explain the differences in opinion in previous literature pertaining to sea level changes in the Nedrow and Moorehouse.

The upper Moorehouse is marked by a coarse crinoidal grainstone to packstone resting atop a slightly irregular disconformity. The fining upwards trend that begins at the unconformity represents the lower part of the TST of Cycle 2. The TST continues throughout the upper Moorehouse and the Seneca before terminating at the thin, consolidated bone beds at the top of the Seneca. The hash layer represents the MFS of Cycle 2. The variable erosion on the unconformity and the specific facies patterns indicate that there was eustatic control over carbonate succession during the deposition of the Onondaga as a result of the Acadian Orogeny (Brett and Ver Straeten, 1995).

The conclusions of Brett and Ver Straeten (1995) were more consistent with the present study than those of Koch (1982) or Gurney and Friedman (1986). Coarse material atop the Edgecliff indicates a shallowing trend, and no evidence of lagoonal conditions was found in the Nedrow. Bone beds in the Seneca, coupled with a dearth of fossils upsection, are not consistent with a regression. Finer-grained material near the top of the Moorehouse 
indicates that it was transgressing, and this transgression continued into the Seneca and the overlying black shales. It seems unlikely, however, that these facies changes were significant enough to warrant the application of a sequence-stratigraphic model. Subtle and gradual changes occurred on a much smaller scale.

Prior evidence of a very shallow depositional system has become suspect. Lindholm (1969b) reanalyzed previous claims that intraclasts within the Nedrow indicated a shallow environment. These 'intraclasts', however, turned out to be infilled burrows. He thought that a diversified and abundant fauna, and the absence of characteristic structures eliminates the possibility of the Onondaga originating in a supra- or intertidal environment (Lindholm, 1969b).

Selleck (1985) attributed the repetition of fining-upwards beds to be the result of carbonate deposition in episodes, suggesting a subtidal zone in a storm-dominated shelf at a depth between normal and storm wave bases. Based on the presence of numerous storm deposits, it is likely that the shelf remained within storm wave base throughout the time of the Onondaga (Swartz and Swain, 1941).

It seems most reasonable to assume that a shallow epeiric sea within a few degrees of the equator during a time without polar ice caps would have been a tropical environment. The deposition of the Onondaga probably occurred in a subtidal zone, below wave base, but well within the photic zone, and exposed to open-ocean waters.

Faunal Studies

The faunas of the Onondaga are facies-related, not time-related. Each represents a specific environment and this is reflected in the lithology. Many of the Onondaga taxa were present in the underlying Schoharie/Esopus complex or reappeared later in the Hamilton Group (Oliver, 1954). Colonial rugose corals, however, are absent from the Esopus and Hamilton, but are very important in the Schoharie and Onondaga (Oliver, 1976).

The depositional history of the Onondaga directly influenced the faunal history. Because of continuous sedimentation in the eastern areas, conditions were favorable for crinoid, coral and bryozoan growth throughout the time of the Onondaga. Fossils are most abundant in the eastern and western regions of New York because the central region was basinal throughout much of the Eifelian. It should be noted, however, that the term "basinal" is relative. The basin was still relatively shallow, probably only deep shelf.

The central basinal region was the area of greatest subsidence, located in the vicinity of Syracuse and extending southward into Pennsylvania (Lindholm, 1969b). The faunas from this region, particularly within the Nedrow, are poorly developed because the waters were deeper than the eastern and western areas (Swartz and Swain, 1941). During the later part of the Onondaga, during Moorehouse and early Seneca deposition, benthic conditions were more favorable for the development of diverse and extensive faunas (Lindholm, 1969b) even in the central region.

The Onondaga contains a very rich and diversified fauna. Brachiopods occur in all members, facies and zones and often range through more than one stratigraphic unit. Corals, however, are the most important stratigraphic and paleoecological guides, and each member of the Onondaga is characterized by its coral fauna or lack thereof (Oliver, 1954). Members may be identified by their coral abundances rather than the species that are present (New York State Geological Society, 1931). Fossils tend to be more common in the lower section 
of each unit, and the eastern areas of New York are as fossiliferous as the Ohio beds (Lindholm, 1969a).

The fauna of the lower Eifelian is often considered the most diverse of the middle Devonian, probably due to high levels of provinciality (Koch, 1981; Boucot, 1988). Eastern North America was isolated by the Devonian Transcontinental Arch (Oliver, 1976) that extended from Minnesota to Arizona. The Appalachian Faunal Province, in place during the time of the highly provincial Edgecliff, was probably disrupted by the breakdown of barriers during the transgression of Moorehouse time, when cosmopolitan species flourished (Koch, 1981). The end of the Transcontinental Arch led to a decrease in endemism in the late Eifelian, because there was no longer a barrier to migration from the west (Oliver and Sorauf, 1983).

The highest diversity will, logically, develop in environments where there is a stable marine temperature, good circulation, adequate nutrients and normal salinity. Feldman (1980) maintains that an Atrypa-Coelospira-Nucleospira zone, found in the Moorehouse of eastern New York, was most favorable for brachiopods and represents the peak of Onondaga diversity. In general, abundance, particularly brachiopods, increased with depth, to a point, and single taxa dominated where diversity was low, such as in deeper waters.

Feldman (1980) made some generalizations about the brachiopods of the Onondaga. Where sediments are coarser, there is a greater amount of abrasion and, probably, postmortem transport. An Atrypa-Coelospira-Nucleospira community found in the Moorehouse, however, is associated with argillaceous sediments so that very rarely are the valves disarticulated or abraded. Platycerid gastropods with intact spines have also been collected from within this community.

Gurney and Friedman (1986) made the generalization that Middle Devonian corals, crinoids, and bryozoans most commonly occurred in open shelf environments, whereas brachiopods, trilobites and styliolinids were more basinal. This generalization is probably not true for brachiopods, as they occur in every unit of the Onondaga (Feldman, 1980). Where diversity is low for other taxa, brachiopods are often diverse. It should be noted here that the fossils of the Buffalo Museum of Science were regularly associated with corals, bryozoans and brachiopods. Tentaculites is not found with many specimens, but when it does occur, it is very common. Trilobites and styliolinids were not found with any fish fossil in the museum.

Other fossil groups are found in the Onondaga, but are less important to this study. Depending on location, trilobites may be common in all of the members except the Seneca, though they are usually unidentifiable. Crinoids and bryozoans are abundant in all members, though crinoids are rarely entire and very little systematic work has been done on the bryozoans. Ostracods are common but not easily extracted, and blastoids and pelecypods are both very rare. Sponge spicules are reported as being common in the central Moorehouse, but have not been searched for elsewhere (Oliver, 1956a). No spicules were observed in this study.

Paleoecology

Feldman (1980) cautioned that various factors may provide misleading information about the paleoecology of the Onondaga. Local, abrupt changes may alter the diversity, 
density and composition of a fauna. The matrix type, weathering rate and silicification of fauna control relative abundances.

Edgecliff Member

Lithology

Lithofacies are distinguished by the fine-grained matrix or sparry cement, and allochems (Lindholm, 1969a). In the east, the Edgecliff is a medium-to-thick, massive basal bed containing light-colored chert (Feldman, 1985). It is a wackestone to packstone containing large rugose coral reefs (Wolosz and Paquette, 1988; Figure 5), a tabulate coral biostrome (Oliver, 1956a), abundant crinoids and solitary corals (Mesolella, 1978; Rickard, 1981), though the unit may contain allochems to the point where it is considered a grainstone (Oliver, 1956a; Wolosz and Paquette, 1988; Wolosz, 1992). The lower half of the member tends to be darker, finer and thick-bedded with few solitary rugose corals, whereas the upper half is lighter, coarser, more massive and contains abundant solitary rugose and tabulate corals in a crinoidal matrix (Oliver, 1956b). Brachiopods are scarce throughout the Edgecliff (Feldman, 1985). In the central part of the state, only the upper half contains abundant chert (Oliver, 1956a).

In the western part of the state, the Edgecliff is darker, coarser and more homogenized, though there may be beds of greenish shale and disseminated bituminous matter. Crinoids and corals are abundant, though there are no bioherms (Buehler and Tesmer, 1963). Light chert may occur in the uppermost units (Oliver, 1954).

In eastern and southeastern New York, the Edgecliff is transitional with the underlying Emsian-age rocks of the Esopus-Schoharie complex (Kindle, 1913; Oliver, 1954). Underlying rocks get older westward where an unconformity developed (Rickard, 1981) so that the Onondaga overlies the Emsian-age Oriskany (Kindle, 1913) or the Lockhovian-age Helderberg (Oliver, 1954) in the central regions and Silurian rocks in the west. The COSUNA Project of AAPG correlates the base of the Edgecliff with the base of the Columbus (Patchen et al., 1985) (Figure 3B).

\section{Depositional History}

Koch (1982) thought the transgression that began at the base of the Onondaga continued through the upper units of the Edgecliff. This is supported by a basinal deposit, the Nedrow, above.

The near lack of stromatoporoids and algae in New York, usually characteristic of reef buildups in the Edgecliff-equivalent units of eastern Canada, was often used to suggest that the member was deposited in deep or cold water. Stromatoporoid abundance toward the paleoequator in the west (Wolosz, 1991) was thought to indicate a shallow, but cool water origin for the member in New York. Wolosz (Wolosz and Paquette, 1988; 1991) suggested that, even though it developed in shallow water, the ecology of the Edgecliff is analogous to the ecology of modern ahermatypic coral communities.

The breakage, overturning and erosion of fossils, observed by Wolosz (1991) indicate a shallow water environment exposed to open water less than $20 \mathrm{~m}$ in depth (Williams, 1980). Kent (1979) reported undisturbed bryozoans and branching corals, possibly representing lower, though still significant, energy levels. 
Wolosz (1995a) points out three lines of evidence used to show that the Edgecliff was deposited in moderately shallow, temperate waters, though he does not discuss them in detail. First, carbon and oxygen stable isotope analyses on brachiopod valves indicate that the Edgecliff was a relatively cool-water deposit. Second, stromatoporoids increase in size and abundance from eastern New York to western New York to Ontario, or, in other words, toward the paleoequator. Third, thin, dolomitized and bioturbated carbonate muds and solitary rugose and ridge-like bioherms are shallow-water facies and negate prior isotopic and paleontological data indicating that deposition occurred in deeper waters. A shallowwater origin for the bioherms is evident from the stratigraphic setting, faunal succession and lithofacies (Swartz and Swain, 1941). It should be noted that the use of modern carbonate models may be misleading in the interpretation of the Onondaga (Wolosz, 1995a).

\section{$\underline{\text { Faunal Studies }}$}

The Edgecliff contains tabulate corals, rugose corals, pelmatozoans, brachiopods, trilobites, and molluscs, though the latter two faunal groups are less common (Rickard, 1981). In the east, reef structures, however, are characteristic of this member. Though many of the Edgecliff reef-building species occur in western New York and later in the Moorehouse member, they do not form reefs in that region or within the younger member (Oliver, 1956a; Friedman, 1985). The term, "reef", should not be used to refer to carbonate structures of western New York nor of the Moorehouse because there is no framework structure. Masses of corals from those units are more appropriately referred to as bioherms.

Most Devonian reefs are formed by stromatoporoids. The Onondaga is unusual in that its biogenic mounds are formed by corals, followed by crinoids, brachiopods, molluscs, unrecognizable parts, and sponges (Freidman, 1995; Bruner and Smosna, 2002). In Ontario, five species of large stromatoporoid are present in the Edgecliff (St. Jean, 1983; 1986), but stromatoporoids are rare and small in western New York and absent in the east. Due to the lack of stromatoporoids and the subordinate role of tabulate corals, true framework reef structures are rare. Bioherms develop as the result of the spreading growth patterns of phaceloid morph colonial rugose corals. Phaceloid coral growth refers to corallites growing nearly parallel to each other and joined only by the occasional lateral process (Hill, 1956). The small and delicate nature of these corals did not allow for significant structure (Wolosz, 1982).

Where they occur, the Edgecliff reefs are usually built upon topographic highs and often extend into the overlying members. Where a true reef developed, overlying Onondaga members may be missing or will lap the sides of the reef complex (Van Tyne, 1996). Colonial rugose corals are the main builders, forming large reefs, though solitary rugose and tabulate corals (Oliver, 1954) particularly in the east, may form smaller reefs (Oliver, 1976).

Most Edgecliff reefs are composed of two paleocommunities, the first containing phaceloid rugosan mounds and thickets, the second, favositid and crinoidal sand banks (Wolosz, 1992; 1995b). The rugose mounds were typical of shallow water areas. Most other taxa were restricted by the growth of these corals (Wolosz, 1995b). Rugose mounds may be a few meters in diameter and a meter or so thick up to over 200 meters in diameter and 15 meters thick (Wolosz, 1991). Thickets were also features of shallow water, but occurred further offshore in deeper water. However, their position on a topographic high brought 
them into relatively shallow waters (Wolosz, 1995b). Shield shaped rugose thickets may be 240 meters in diameter and six meters thick (Wolosz, 1991).

Much further offshore, in deeper waters, large banks occurred (Wolosz, 1995b). Favositid corals dominate but never develop a framework mass, so other organisms are not restricted and diversity is quite a bit higher here. Crinoids are very common, though calyxes are never found. Solitary rugose corals and fenestrate bryozoans occur so that these facies resemble the flank facies of Lindemann (1989; see below). Delicate branching corals such as Cladopora and Syringopora are the rarest forms, usually restricted to mud mounds (Wolosz, 1995b). Pinnacle reefs can be 60 meters thick and extend for three kilometers before they start interfingering with the crinoid flank facies (Wolosz, 1991). Wolosz (1992) suggested that the appearance of the favositid and crinoidal banks atop the rugosan mounds marks a transition into deeper water where turbidity was not enough to support rugose reefs. Alternating layers may be the result of the effort of the reef to maintain a constant water depth during changes in relative sea level.

During Edgecliff-time, the eastern, central, and western areas were all characterized by well-agitated waters where corals thrived (Oliver, 1954). Shelf patch reefs of today might serve as a good analogy (Oliver, 1956a; Williams, 1980). Even though the fauna persisted throughout the rest of the Onondaga in eastern New York, conditions were not suitable for reef growth because the sea had become muddier (Oliver, 1954). The areas surrounding eastern New York underwent a faunal change at this time, but the turnover did not affect eastern New York (Oliver, 1956a).

Wolosz (1982) and Wolosz and Paquette (1988) reported a succession of coral taxa within the reefs of eastern New York. Colonization began with the delicately branched Acinophyllum (Synaptophyllum), was followed by the more robust Cylindrophyllum (Eridophyllum) and capped by the thicker corallites of Cyathocylindrium. Surrounding the reef core is a specious crinoidal packstone containing brachiopods, gastropods, bryozoans, ostracods, solitary rugose corals and trilobites, though the most obvious constituents are Emmonsia in the fore reef and Favosites in the back reef, both favositid corals. The tabulate corals are spaced far enough away from each other that there is no framework (Wolosz and Paquette, 1988). Eventually, Acinophyllum, then Cylindrophyllum and finally Cyathocylindrium colonized the crinoidal packstone, and the reef would continue to grow, both vertically and laterally (Wolosz, 1982). These species of coral extend, uninterrupted, into the Moorehouse in eastern New York (Oliver, 1956a), but they do not form reefs.

Lindemann (1989) published a detailed report on the stages of substrate colonization, upward growth and diversification and how they provide strong evidence that the Edgecliff was shallower than wave base. He was able to identify basal, core, flank and cap facies. The terminal cap was once thought to have been the result of growth into the wave base, but adjacent areas indicate that a sea level lowering was responsible for bringing the reefs into wave-dominated depths.

The cores of the bioherms in his study were lithified early, but the flank and cap remained unlithified for some time. Corals and brachiopods, crushed and broken after deposition, are also restricted to the cap and flank facies. The conchs of tentaculitoids are deformed (Lindemann, 1989, 1995), usually dorsoventrally compressed. These characteristics indicate that the flank and cap facies may have been more susceptible to deformation due to the lack of lithification. 
Lag deposits of rugose corals, redistributed by storm and/or tidal currents, provided the template necessary for tabulate coral reefs to develop during Edgecliff time. On the flanks, rugose corals and ostracods could exist in small numbers, but crinoids probably dominated. Once formed, these reefs baffled the current and provided a buffer so that rugose corals and ostracods could survive in the protected area behind the reef. Farther from the reef, reef talus accumulated (Williams, 1980).

Due to their size and the thin nature of the Nedrow, the Edgecliff reefs, though no longer living, remained above the level of sedimentation through the time of the early Moorehouse (Oliver, 1956a). The considerable thickness and purity and the lack of shaly partings within the limestones containing these bioherms indicate that constant, clear water conditions persisted throughout the time of reef growth during Edgecliff time (Oliver, 1954)

In western New York, the most significant biological build-up, the Leroy bioherm, is 150 meters in diameter and six meters in thickness. The Leroy bioherm is unique in that it is dominated by the tabulate coral, Cladopora, not rugose corals (Wolosz and Paquette, 1988). The bioherm formed on a carbonate shelf in moderately deep to shallow subtidal waters (Lindemann, 1989). Even though it is not a true framework structure, the four distinct facies typical of modern reefs are observed in the Leroy bioherm: basal, core, flank and cap. The bioherm began the same way that other Onondaga bioherms began, with the colonization of Acinophyllum corals. The infill of carbonate mud into the densely packed corallite framework comprises the basal facies (Lindemann, 1989).

The establishment of Cladopora forms the massive, medium gray bafflestone of the core facies. Carbonate mud and fossil debris comprise the matrix, and the encrusting bryozoan Fistulipora may be present (Lindemann, 1989).

Flank facies are limited to the western side of the bioherm, probably reflecting the direction of paleocurrents. Bedding is the result of the alternate layering of crinoidal packstones, wackestones and bafflestones of Acinophyllum, Cladopora and the solitary rugose coral, Heliophyllum. The flank dips away from the core at 8-12 degrees (Lindemann, 1989).

The cap of the Leroy bioherm is most apparent on the east side of the structure. It is comprised of wackestones surrounding Heliophyllum and Cladopora colonies and stromatoporoids and fossil debris may be locally common. It covers both the core and flank facies, though grain size does decrease away from the core (Lindemann, 1989).

The reefs of the Edgecliff are quite different from reefs of other ages. Models of reef development are usually based on long-lived reefs that undergo succession. However, most Onondaga reefs are short-lived and their succession is limited. Stromatoporoids are rare, algae is even rarer, and lateral development is limited so that only patches of reef-like structures develop. These reefs appear similar to modern reefs that are subjected to a great deal of storm perturbation (Lindemann, 1989).

Platycerid gastropods are associated with the biological structures in the Edgecliff of western and eastern New York. They are not found in the central region where build-ups are absent, though they do appear in the fine-grained rocks of other members (Oliver, 1956a). Generally, platycerids are thought of as constituents of the impoverished faunas of harsh environments (Rickard, 1981). The symbiotic relationship between platycerid gastropods and crinoids may explain the association of the snails and corals. Crinoids are often constituents of the reefs (Oliver, 1954), and given their established relationship with playcerid gastropods (Hess et al., 1999) are probably the true commensalistic partner of the 
snails. In addition, the high degree of overlap between units may cause taxa to be present in units in which they would not normally occur. A more comprehensive study on the individual species of the Eifelian gastropods may help to establish the importance of this group in paleoecological reconstructions.

The lower section of the Edgecliff in eastern New York contains a high percentage of argillaceous material because it was basinal at the time. This is a continuation of conditions present during the time of the deposition of the muddy and silty Schoharie Limestone (Oliver, 1956a). Below the Schoharie, and gently grading into it, is the Esopus, a sandy shale that rests on the Oriskany Sandstone (Schuchert, 1943). Faunal similarities between the Schoharie-Esopus complex, Emsian in age, and the Onondaga, particularly the brachiopods, Leptocoelia acutiplicata, Atrypa spinosa (Schuchert, 1943) and Anoplotheca acutiplicata, indicate that the transition between the Emsian and Eifelian in eastern New York was rather gradual (Kindle, 1913). Microfossils indicate an even less abrupt change than the benthic invertebrates (Liu et al., 1988).

\section{$\underline{\text { Zones }}$}

Oliver (1956a) divided the Edgecliff of central New York into two major zones (Table 1, Figure 7). The first, 'A', was the Springvale sandy horizon, the result of reworked Oriskany Sandstone. The second, ' $\mathrm{C}$ ', is the massive gray coralline limestone characteristic of the Edgecliff. It can be divided into two subunits, appropriately called, ' $\mathrm{C} 1$ ' and ' $\mathrm{C} 2$ '. The lower unit, ' $\mathrm{C} 1$ ', is finer-grained, darker and contains much less chert and fewer, though similar, fossils when compared to the 'typical' Edgecliff. The fauna is reminiscent of the underlying Schoharie and Esopus units, though the lithology is different (Wolosz and Paquette, 1988). Oliver (1956a) found phosphatic nodules and glauconite in this unit. Wolosz and Paquette (1988) suggested that energy levels might have been too high for rugose corals to survive, though dark, fine-grained rocks with few fossils are usually indicative of low-energy environments. The presence of glauconite, a product of reduction in a dysaerobic environment, also indicates a low-energy, deep-water environment. A high mud concentration and/or low temperatures were probably the factors that prohibited rugose coral survival. The unit was probably deposited in a relatively deep-water environment that followed the initial Onondaga transgression.

The transition from a phosphate nodule-bearing glauconitic limestone, to a gray shale and limestone to a black chert, and the fact that the unit underlies 'typical' Edgecliff led Oliver (1956a) to consider placing the unit within the Schoharie. However, the occurrence of the same platycerid gastropods that are found in the Nedrow, but not the Schoharie, and the position of the unit on the Emsian-age Carlisle Center Formation prevented the unit from being anything but lower Onondaga. The Carlisle Center Formation forms a sharp contact with the Onondaga in eastern New York (Leibe and Grasso, 1990).

The upper unit, 'C2', is the light-to-medium gray, coarse coral zone that is typical of the Edgecliff. Numerous solitary rugose and tabulate corals characterize the zone (Oliver, 1954), though closely packed tabulate coral colonies are not common (Oliver, 1956a). The abundance of corals is high, but diversity is not. Tabulate corals are usually found in an upright position, but solitary rugose corals show signs of postmortem wear. Crinoids are large and become the most common faunal constituent. Brachiopods are not common, though most Edgecliff horizons are represented by a few specimens. Fenestrate bryozoans 
are common but do not dominate. Other faunal elements such as gastropods and trilobites are rare (Oliver, 1954). Light gray chert is abundant, though highly variable (Oliver, 1956a). The ' $\mathrm{C}$ ' zones appear to indicate a shallowing upward trend.

In the Buffalo vicinity, Zone ' $A$ ' is recognized at most locations, though it thins and even disappears further to the west. Zone ' $\mathrm{C}$ ' is continuous across the area, though there is more light chert and some interfingering with the Nedrow. The fauna is similar to that of the central region, though in extreme western New York, there is at least one bioherm with a different fauna. Colonial rugose corals, stromatoporoids, and gastropods, with solitary rugose corals and brachiopods, occur on the fringe (Oliver, 1954).

An Atrypid-Megakozlowskiella brachiopod community occurs in the western Edgecliff, the Edgecliff, and lower Nedrow of the central region (Koch, 1981) and the finergrained parts of the eastern "Moorehouse" (Feldman, 1980). In the western part of the state, the habitat was probably a shelf environment; in the central part, it was probably on the slope. Diversity was not particularly high (Koch, 1981). The presence of Megakozlowskiella is the most significant aspect of this community because it is otherwise similar to the Atrypid-Levenea community of younger strata. This environment was probably close to shore and near wave base (Feldman, 1980).

Friedman (1985) noted that the members of the Onondaga in central New York were bathymetrically discernible, though he did not elaborate. He described the Edgecliff as a massive, light gray, coarsely crystalline biostrome characterized by crinoid columns over 2 $\mathrm{cm}$ in diameter, and becoming fine-grained, darker and less fossiliferous to the south.

He also recognized three biozones within the member. The first is dominated by brachiopods and becomes siliceous downsection. The second is a zone of discontinuous coral that is only found in western New York and Ontario. The third is the unit of rugose and tabulate corals usually associated with the member (Friedman, 1985).

Nedrow-Clarence

Lithology

In eastern and central New York, the Nedrow is a thin-bedded to shaly (Oliver, 1956b), argillaceous wackestone and calcareous shale that grades upward into a cleaner, chertier, coarser, more massive limestone (Mesolella, 1978; Rickard, 1981), particularly in the eastern and west-central regions of New York (Rickard, 1981; Feldman, 1985). The chert is blue-black, very abundant and is often bedded. Differential weathering gives the Nedrow a rough appearance (Buehler and Tesmer, 1963). In the central region, where it is more argillaceous, recessed weathering may occur (Feldman, 1980). The lower section is characterized by platycerid gastropods and brachiopods, and goniatites can be found in the upper section (Oliver, 1956b), but, except in the central region (Oliver, 1954), the unit is never very fossiliferous (Buehler and Tesmer, 1963). Near the top, widespread black shales reappear (Brett and Ver Straeten, 1995), and the unit grades into the massive, fine-grained Moorehouse (Oliver, 1956b).

In western New York, the Nedrow is replaced by the Clarence Member (Wolosz, 1992), though some authors (Brett and Ver Straeten, 1994) feel that the Clarence is a facies of the Edgecliff. Regardless, the Clarence is basically a chert containing lenses of crinoidal packstone. The light colored, nodular chert may comprise 75 percent of the rock volume 
(Selleck, 1985). Fossils are scarce (Wolosz, 1992), as exemplified by the presence of only a few trilobites and a few rugose corals in the beds of the Cheektowaga Quarry.

Most reports refer to outcrops as far east as Batavia and Leroy as "western New York", and very few indicate that the Buffalo vicinity was examined. From around Syracuse and west to the areas considered "western New York", the Nedrow has been interpreted as interfingering with the Clarence (Wolosz, 1992) or resting atop the Clarence, which interfingers with the Edgecliff (Brett and Ver Straeten, 1994). In the Buffalo area, the Clarence is very distinct and the Nedrow is completely missing, indicating that the Clarence has replaced the Nedrow. For this and other reasons to be explained later, the present study will retain the Clarence as a distinct member of the Onondaga.

\section{Depositional History}

Koch (1982) thought that the transgression of the Edgecliff was followed by a regression during the time of the Nedrow that formed a sharp contact with the underlying Edgecliff (Oliver, 1954). The reefs surrounding the basin formed barriers to circulation, and isolated lagoons appeared on the platform. Evidence for the regression may be the extensive evaporites of Michigan that formed during the time of the Nedrow (Koch, 1982). The regression may have isolated the Michigan Basin from circulation and lessened the water depth. This, coupled with a close proximity to the paleoequator, would have been favorable for the build up of evaporites (Koch, 1981).

The argument for a regression during Nedrow time stems from the idea that the argillaceous nature of the Nedrow may not have been the result of deeper-water environments. Changes in the Nedrow could have been the result of fluctuation in sediment rates, so that during periods when shalier units were deposited there were low levels of carbonate production (Koch, 1981; Gurney and Friedman, 1986). The relative absence of corals in the Nedrow is due to the influx of mud during the regression. As the member becomes more argillaceous, platycerid gastropods dominate and brachiopods diminish in number (Oliver, 1956a). The increase in clay production may have be the result of a pulse of Acadian orogeny that deepened the Appalachian Basin (Koch, 1981). The hypothesis of a Nedrow-age regression relies heavily on the correlation of the Nedrow with the Lucas Formation of the mid-west, thought to be highly correlable with the evaporites of Michigan (Koch, 1981). This correlation was not supported by subsurface gamma-ray logs (Rickard, 1984), and no evidence was found in western New York to support a shallow-water origin for the Clarence. The copious amount of chert associated with the Clarence is secondary and does not provide information pertaining to the depositional history.

\section{$\underline{\text { Faunal Studies }}$}

Finer-grained rocks are usually deposited in environments that are less than ideal for most organisms. This may explain why the Nedrow is dominated by platycerid gastropods (Rickard, 1981), a group that can be associated with harsh living conditions. The lack of other fossils certainly supports the idea that living conditions were not ideal for many species. The gastropod diversity is more impressive than their abundance, though many species may be ecotypes (Oliver, 1956a). Tentaculitoids, particularly Styliolina fissurella, 
are most common in the Nedrow and in the central regions of the state (Lindemann and Yochelson, 1984). Goniatites from the upper Nedrow represent some of the oldest goniatites in North America. Brachiopods are abundant, though the lack of corals and crinoids in all locations except the east is the most significant aspect of the fauna (Oliver, 1956a). The lithological similarity between the Nedrow and the Hamilton Group (Willard, 1936) may indicate that the Nedrow was deposited in similar offshore conditions (Lindemann and Yochelson, 1984). Faunal reports from the Clarence, the western equivalent of the Nedrow, are rare.

\section{$\underline{\text { Zones }}$}

Oliver's (1954) Zones ' $D$ ' and ' $E$ ' fall within the Nedrow. Zone ' $D$ ' is the lower, shaly portion of the Nedrow that grades upward into a fine-grained, massive limestone. Platycerid gastropods, abundant to the point where the zone can be referred to as a platycerid zone, diminish upwards and brachiopods become more abundant, though no brachiopod taxon ever dominates the unit (Oliver, 1956a). Gastropods are more diverse, and many are unique to the zone, but they are outnumbered by brachiopods. Heliophyllum halli and Amplexiphyllum hamiltonae are rugose corals that are rare in other units, but common in this zone. It seems that the conditions of Zone ' $\mathrm{D}$ ' were ideal for mud-tolerant species (Oliver, 1954). However, the lithology and paleontology indicate that the Nedrow began in deeper water and shallowed upwards.

Zone ' $\mathrm{E}$ ' is similar, though fossils and chert are less abundant. The transition from ' $E$ ' to ' $F$ ' is so gradual that differentiation is marked only by the disappearance of species, not lithology. (Oliver, 1954). Because of the shaly nature of the Nedrow, good exposures are rare and these zones are not as well known as the others (Oliver, 1956a).

Zones ' $D$ ' and ' $E$ ' of central New York are unrecognizable west of the Auburn quadrangle. Farther west, the beds of the Nedrow, and eventually the Clarence, contain the fewest fossils of any Onondaga horizon in New York (Oliver, 1954).

Friedman (1985) described the Nedrow as being a thinly-bedded limestone containing as much as 25 percent clay and Oliver's (1954) faunal zone 'D'. This zone is characterized by the presence of Heliophyllum halli, Amplexiphyllum hamiltonae, platycerid gastropods, and brachiopods, but few other corals. Higher upsection, the Nedrow becomes less argillaceous and Oliver's (1954) zone ' $\mathrm{E}$ ' is present. This zone is thicker and contains more brachiopods than zone ' $\mathrm{D}$ '. The dearth of faunal elements in the Nedrow is not only due to poor living conditions, but also poor preservation (Oliver, 1954). Lindemann and Yochelson (1984) suggested that the argillaceous nature of the Nedrow might reflect the offshore conditions of the overlying Givetian-age Hamilton Group.

An Atrypid-Megakozlowskiella community is found in the lower Nedrow of the central region (Koch, 1981). Based on the presence of several corals, the community probably lived in an area of higher energy, but close to the slope. An Atrypid-Levenea community, probably formed in a mid-neritic habitat, was found in the upper Nedrow by Koch (1981). 
Moorehouse

$\underline{\text { Lithology }}$

The Moorehouse comprises the largest section of the Onondaga in many locations in western New York. It tends to be dark-gray and very fine-grained, with black chert (Oliver, 1956b; Feldman, 1985) and shaly partings (Wolosz and Paquette, 1988), though it may be tan and/or coarse-grained in places (Buehler and Tesmer, 1963). The limestone is less argillaceous in the west, but chert is much more common than the units of the eastern region (Oliver, 1954). Corals and bryozoans are common throughout (Buehler and Tesmer, 1963). Gyroconic nautiloids are characteristic, but brachiopods dominate the lower Moorehouse (Oliver, 1956b). The upper portion is marked by a coarse crinoidal grainstone to packstone, but begins to fine upward above a slightly irregular unconformity (Brett and Ver Straeten, 1995). The dark-colored Moorehouse chert is nodular and commonly associated with dolomite. It is most common in the upper wackestones and bioclastic packstones and may represent the replacement of burrows. Coarser rocks possess no chert except for areas surrounding burrows (Selleck, 1985). It is hard to distinguish the Moorehouse from the Nedrow and Seneca in eastern New York (Oliver, 1956a). In western New York, the Moorehouse is gradational with the Clarence, but easily distinguished from the Seneca above.

The Moorehouse is overlain by the Tioga Bentonite (Mesolella, 1978), an ash layer that resulted from a volcanic eruption somewhere in Virginia (Rickard, 1981). The Tioga formed as an eolian deposit and contains some volcanic mica (Lindholm, 1969a). It is detectable in the subsurface by its sharp gamma-ray spike (Mesolella, 1978). In addition, there are two other less significant ash layers in New York outcrops at or near the Onondaga/Marcellus boundary (Rickard, 1984). The Tioga is now more appropriately called "The Onondaga Indian Nation (OIN) Bentonite" (Sparling, 1988), or Tioga B (Brett and Ver Straeten, 1994), but due to entrenched usage, it will be referred to simply as the Tioga throughout this work.

\section{$\underline{\text { Depositional History }}$}

Koch (1981) thought that a transgression during Moorehouse time terminated at the Tioga Bentonite (Koch, 1982). Just prior to the transgression, the deepening of the basin, thought to have prevented carbonate production in the Nedrow, ended and carbonate material in the central areas increased (Koch, 1981).

Gurney and Friedman (1986) thought that the lower Moorehouse represents a single regression, based on an increase in coarse-grained skeletal material and a decrease in finegrained material toward the upper portion of the unit. The coarsening upward sequence is followed by a transgression marked by an influx of fine-grained carbonate material in the upper unit. Bryozoan fragments result from the subsequent regression that signals the end of the Moorehouse transgression.

\section{$\underline{\text { Faunal Studies }}$}

In the central and eastern regions of New York, the Moorehouse is dominated by brachiopods, and there is a great deal of species overlap between the two regions (Oliver, 
1956a). Gyroconic cephalopods are characteristic of the central region, but become rare in the eastern units. Zaphrentid corals are common in the central area and darker rock units, whereas tabulate and large rugose corals only occur in the eastern areas and the lighter, coarser rocks. Platycerid gastropods occur in the fine-grained beds of the member, but disappear as the grain size increases, particularly in the east (Oliver, 1956a). Styliolina fissurella is common in parts of the Moorehouse (Oliver, 1954). In the units of southeastern New York, normal benthic fossils are absent, though trilobites are common. The presence of trilobites, not normal benthic fossils in southeastern New York, may indicate that these trilobites were semipelagic (Oliver, 1956a).

In western New York and in the undifferentiated units of eastern New York, solitary rugose and tabulate corals formed biostromes. Gastropods are absent, but otherwise, the fauna is similar to that of the central region (Oliver, 1954).

$\underline{\text { Zones }}$

The lower unit of the Moorehouse, Zone ' $\mathrm{F}$ ', is a zone of sparse chert and few fossils (Oliver, 1954; 1956a), though brachiopods may be common (Friedman, 1985). Feldman (1980) reported a silicified fauna dominated by gastropods and atrypid brachiopods. He suggested that poor circulation and low oxygen levels were responsible for the paucity of the fauna.

Zone ' $\mathrm{G}$ ', however, the upper unit of the Moorehouse, contains abundant black chert and the most species of any Onondagan zone, though it is gradational with Zone ' $F$ '. This faunal assemblage is unique and marks the first appearance of many Onondaga taxa (Oliver, 1954). Halloceras undulatum is characteristic of the zone, though there is a wide variety of brachiopods (Oliver, 1956a), gastropods, cephalopods, trilobites, and molluscs (Friedman, 1985). Zones ' $D$ ' and ' $G$ ' are similar in that they are characterized by gastropods, though gastropods are outnumbered by brachiopods, and they represent a return to better benthic conditions. They differ in lithology and the taxa of organisms. Zone ' $\mathrm{G}$ ' is similar to units of the Columbus Limestone where fish fossils have been collected (Oliver, 1954). Since the present study is the first to place larger plates and bones into a stratigraphic horizon, it is presumed that Oliver (1954) was referring to the units of the Columbus where bone beds are found.

The western Moorehouse around the Honeoye quadrangle exhibits little to no faunal or lithologic change; therefore zones ' $F$ ' and ' $G$ ' become indistinguishable. Further west, the Moorehouse is a coral facies that is lighter, purer and coarser than the central region. It is similar to the Edgecliff as it appears in eastern localities.

An Atrypid-Levenea community in the upper Nedrow and the entire Moorehouse was, like the underlying Atrypid-Megakozlowkiella community a shelf environment in western New York, but a slope environment in the central area. This depth range places the assemblage in the subtidal photic zone where Boucot's (1975) Assemblage 3 could survive. This assemblage was characterized by a medium to high diversity in a low energy environment and was probably in the subtidal zone of a shallow shelf (Koch, 1981).

An equivalent Atrypa-Coelospira-Nucleospira community, described by Feldman (1980) in the Moorehouse of eastern New York, was the most hospitable for brachiopods since diversity is greatest there. The presence of a diverse coral fauna indicates that this community may have existed in deeper offshore waters, though a high rate of disarticulation 
among brachiopods may indicate that the current was relatively strong and, perhaps, sufficient to prevent debris from inhibiting coral growth. Atrypa, Coelospira and Nucleospira are low-level suspension feeders that prefer a soft, muddy substrate and welloxygenated water.

Feldman (1980) speculated that the Atrypa-Coelospira-Nucleospira, AtrypidMegakozlowskiella, and Atrypid-Levenea communities were mid-neritic. He based this speculation on the argillaceous nature of the rocks, the high species diversity and the presence of ammonoids that are most common in deeper waters.

The Moorehouse marks a return to ideal benthic conditions, essentially the reverse of the Nedrow. The lighter, and coarsely crystalline sections and the crinoidal and coral elements are reminiscent of Edgecliff rocks. There are similarities between the undifferentiated upper parts of the Onondaga in the eastern part of the state and the western Moorehouse, but the faunas are much more distinguishable in the west. The lithology indicates that they were deposited in clear, agitated water (Oliver, 1954).

Seneca

Lithology

In eastern New York, the lithology of the Seneca is slightly different than that of the Moorehouse (Wolosz and Paquette, 1988). It is more argillaceous, lighter (Oliver, 1956b), the grains are finer (Mesolella, 1978; Rickard, 1981), there is very little chert (New York State Geological Society, 1931), and there is a difference in the faunas (Wolosz and Paquette, 1988). Thin, consolidated bone beds appear near the top (Brett and Ver Straeten, 1995), but the unit is generally massive (Oliver, 1956b). Toward the west, the two members are more lithologically and paleontologically similar (Wolosz and Paquette, 1988), though the Seneca may be a bit coarser-grained. Brachiopods dominate the impoverished fauna (Oliver, 1956b), and three meters above the Tioga Bentonite a chonetid brachiopod fauna is often used as a marker bed (Feldman, 1980; 1985). The faunal break near the base of the Seneca marks the transition to deeper waters that would culminate in the deposition of the overlying Marcellus Shale (Feldman, 1980).

The bone beds of the Seneca show that the unit was deepening. The bone beds are transgressional lag deposits indicating an inundation during the time of the upper Seneca. This event is similar to what occurred in earlier units of the Delaware and North Vernon Limestones (Leonard, 1996), both correlable with the Seneca (Patchen et al., 1985; Shaver, 1985), and discussed later.

\section{Depositional History}

Koch (1981) thought the transgression of the Moorehouse was followed by a regression throughout the Seneca. Feldman (1980) and Gurney and Friedman (1986) thought the Seneca was a deepening upward unit. The presence of bone beds and low faunal diversity near the top supports a transgression through the Seneca. 


\section{$\underline{\text { Faunal Studies }}$}

Diversity decreases upward throughout the Seneca (Table 1). The fauna of the basal units are similar to that of the upper Moorehouse, though there are fewer taxa and specimens. Near the center, a well-known Chonetes zone occurs (Oliver, 1954). The top is marked by taxa characteristic of impoverished faunas (Feldman, 1980).

\section{$\underline{\text { Zones }}$}

Oliver's (1954) Zone 'I' occurs in the lower section of the Seneca. This zone is lithologically similar to Zone ' $G$ ', but has fewer species and the first common occurrence of Chonetes lineatus. Zone ' $\mathrm{J}$ ' is often referred to as the "pink Chonetes zone" because the $C$. lineatus may be stained pink (Oliver, 1954). The pinkness is due to grains of ferrous oxide, though the origin of the grains is unknown (Zenger, 1967). Near the top of the zone is a chert bed containing Coleolus crenatocinctum and Loxonema sicula (Oliver, 1954).

Throughout the Onondaga, brachiopods tend to become more diverse and abundant as water depth increased, though the Chonetes zone, where diversity drops and a single taxon dominates, is an exception (Feldman, 1980).

Fossils increase throughout the middle units of the Seneca to an area near the top at which point fossils become scarce. In the upper part of the Seneca, the base of zone ' $K$ ' is marked by a bed of small Heterophrentis, a small zaphrentid coral that may be common in environments less than ideal for other taxa. The matrix of the bed is dark gray with little chert. This dearth of fossils is not often seen because, due to erosion, most exposures only contain the middle and lower sections. Because the contact between the Onondaga and Marcellus, where present in the east, is gradational (Oliver, 1976), the Seneca may mark the end of favorable conditions (Oliver, 1954) and a transition into deeper waters (Feldman, 1980). The lower units of the Marcellus are deepwater muds that become sandier upsection (Bailey, 1983). It appears that the Onondaga was generally deepening through the Moorehouse and Seneca and into the Marcellus.

Oliver (1954) found no Seneca west of Caledonia, though it was reported by Koch (1981) resting atop the Tioga, and was visited during the course of this study.

The Atrypid-Levenea community extends into the Seneca in western New York, but the central Seneca is dominated by the Chonetes community. This is clear evidence that the central region was in deeper and more turbid water (Koch, 1981), though the basin was probably not particularly deep.

The Chonetes community was much lower in diversity, probably because there was a great deal of suspended matter that interfered with nutrient intake and larval settlement of other organisms. Chonetes were more tolerant of a deeper shelf to basinal environment characteristic of Assemblage 4 (Koch, 1981).

Friedman (1985) describes the Seneca as being a dark, shaly unit containing abundant Chonetes lineatus, Dalmanites selenurus and large coiled cephalopods. He thought it might signal a return to Nedrow conditions. 
Corals

Corals require water movement to bring in nutrients and remove waste products. If the water is too turbid, feeding and respiratory apparatuses will become clogged (Prothero, 1998). If the currents are too slow, adequate food filtration may be impossible and the coral will starve.

Coral growth occurs in two forms, solitary and colonial. Solitary corals possess no real means of anchorage and prefer soft substrates. Soft substrates are usually associated with lower energy levels. Colonial corals embed themselves in the substrate without cementation, but their larger size and even base makes them more stable. Energy levels can be high, but not so high as to prevent initial larval settlement or break the delicate structures.

During the Eifelian, neither growth habit used cementation to anchor the individual rugose corals, so no large reefs were formed by them. The need for softer sediments and the lack of cohesion between individuals kept rugose corals out of areas of harder substrates and prevented them from becoming framework builders. The abundance of rugose corals decreases drastically shoreward and basinward (Clarkson, 1986). This distribution indicates that rugose corals could only exist in a narrow paleobathymetric range, depending on the conditions of the sea. They were probably limited by higher energy levels and harder substrates in shallower water and temperature, light penetration and turbidity in deeper waters.

Modern corals exhibit two life strategies. Hermatypic corals are generally restricted to less than 90 meters of water depth and temperatures between $25-29^{\circ} \mathrm{C}$ because they possess a mutualistic algae, zooxanthellae, in their tissues. Clear, well-luminated water is necessary for the algae to photosynthesize. With the constant and reliable nutrient supply provided by the algae, hermatypic corals can get quite large and survive in habitats with low nutrient levels. Their corallites tend to be small, though integration and coloniality are high. They most commonly occur in mounds, sheets or branches (Prothero, 1998).

Ahermatypic corals do not possess zooxanthellae. They can survive in colder or deeper environments, but their growth is much slower. Their corallites are large and there is very little integration among colonial forms (Prothero, 1998).

There is good evidence for the presence of intertissue zooxanthellae in the scleractinid corals of the Cretaceous. However, an algal relationship with the corals of the Paleozoic has only been speculated (Prothero, 1998). Colonial corals of this era exhibit little integration and corallite size is large (Clarkson, 1986), similar to the growth habits of ahermatypic corals.

One should use caution in attempting to equate Paleozoic forms to modern, postPaleozoic forms. A clear, well-luminated sea may not have been necessary for the survival of Paleozoic corals. In fact, modern ahermatypic corals may be used as an analog for Paleozoic bioherms (Wolosz and Paquette, 1988; Wolosz, 1991). Paleogeographic reconstructions indicate that the New York region was located around 35 degrees south latitude (Scotese, 2002). Modern corals cannot exist beyond about 25-30 degrees north and south latitude, though there are exceptions where warm water currents extend to higher latitudes (Wells, 1957). During the Eifelian, a lack of polar ice and the shallowness of the epeiric sea would have kept the waters warm and may have allowed hermatypic corals to exist outside of the tropical latitudes of modern seas. Large corallites with low levels of 
integration may have been the only form possible due to morphological or environmental restraints.

\section{HISTORICAL STUDIES-COLUMBUS/DELAWARE}

The Columbus Limestone was named by Mather in 1859 (Sparling, 1988), but the first full description came from Newberry in 1871 (Stauffer, 1957). Newberry was also the first to use the name 'Columbus Limestone' to describe the very light-colored limestone of north-central Ohio (Sparling, 1988). The six meters of blue rock above were designated as the 'Sandusky Limestone', later to be renamed 'Delaware Limestone' after it was officially described near Delaware, Ohio (Sparling, 1988). The Tioga Bentonite separates the two (Mesolella, 1978) at some locations. The Columbus and Delaware are considered part of the Onesquethaw Stage (Oliver, 1976; Figure 3A) beginning at the earliest Eifelian (Sparling, 1988).

The Columbus Limestone is micritic to sparitic (Taylor and Camp, 1986) with purity levels nearing 95 percent (Forsyth, 1988). The lower lithofacies may be dolomitized though the upper units are not. An abundant fauna includes rugose and tabulate corals, stromatoporoids, gastropods, chonetid, strophomenid and spiriferid brachiopods, and crinozoans (Taylor and Camp, 1986; Kindle, 1913; Schuchert, 1943). Like the Onondaga, a thin basal conglomerate may be present (Kindle, 1913), and probably represents a transgressive lag deposit. These beds are never fully described, but are presumed to be calcareous debris, since siliciclastic material is very rare in the units of the Columbus and the underlying units are also limestones.

\section{Stratigraphy}

Wells (1947) was the first to divide the formation into the most familiar members (Figure 6), though divisions are not often used in more current literature to describe the Columbus. The basal member is a brown, high magnesium limestone about 15 meters in thickness called the Bellepoint Member. A basal limestone conglomerate grades upsection to a zone of few fossils. During the early part of the Eifelian, prior to Columbus deposition, the seas became restricted so that salinities reached very high levels. It was around this time that the underlying Amherstburg and Lucas Dolomites were deposited (Sparling, 1988). True reefs are absent in the Columbus, but the upper section of the Bellepoint is marked by a zone of abundant corals and stromatoporoids (Stauffer, 1957; Sparling, 1988) and may be considered a biostrome (Wells, 1947).

Above the Bellepoint, there is a great deal of discrepancy in subdividing the Columbus. Wells (1947) described the Ebersole, a two-meter fossiliferous unit of alternating light chert and pure limestone, containing a bed with a number of large gastropods. $\mathrm{He}$ proposed that the chert originated from a syngenetic silica gel because it is so different from the secondary and concretionary cherts of the other units (Stauffer, 1957). It is most likely, however, that the chert was formed by the recrystallization of siliceous sponge spicules as in the Onondaga, as there appears to be no other source for the chert. 
Wells' (1947) top layer was the Delhi Member, a 20 meter thick, pure, highly sparitic, limestone with no chert, but a substantial fauna. Gastropods, common in the Delhi, are not found above or below this member, except for the bed within the Ebersole.

The upper two Columbus units of Swartz (1907, in Sparling, 1988) and Sparling (1983, 1988) are the gray-brown-to-tan Marblehead Member and the gray-blue Venice Member, though Sparling (1983) considers the Marblehead to be a subunit of the Bellepoint. The coral zone at the top of the Bellepoint marks the base of the Marblehead (Schuchert, 1943). The lower units of the Marblehead were deposited in a low energy, semirestricted subtidal lagoon, and there are few fossils. The upper portion, however, suggests that energy levels increased significantly in order for a fossiliferous grainstone to form in a medium-tohigh energy, well-aerated subtidal bank or shoal, probably just below wave base. The fossiliferous Venice was also deposited above the wave base, but in a more quiet setting. This interpretation is based on a higher mud content and the presence of pyrite. A bone bed has been reported at the base of the Venice (Sparling, 1988).

The units above the Bellepoint have also been referred to as the Klondike and the West Jefferson Members. Numerous combinations of all of these names have been used to describe the Columbus (Schuchert, 1943). This is the reason why the formation is rarely divided in more recent reports, and is often referred to as containing the "upper and lower Columbus".

Kindle (1913) and Stauffer (1957) reported that the Columbus is usually found unconformably atop Silurian rocks, except where it rests in the eastern parts of the state on the Onondaga. This led them to believe that there was no Onondaga equivalent in Ohio. However, later reports determined that the units beneath the Columbus were the Amherstburg and Lucas Dolomites (Schuchert, 1943; Sparling, 1988). This indicates that the Columbus and Onondaga may interfinger in the eastern parts of the state, but are still equivalent. It is not clear if sedimentation was continuous, but Onondaga taxa have been found near the top of the Sylvania Sandstone, the unit just below the Amherstburg. The fauna of the Amherstburg and the Lucas are older, but similar to the fauna of the Columbus. The Sylvania Sandstone does rest unconformably atop Silurian rocks (Schuchert, 1943). The age of the three units below the Columbus has been reported as Emsian (Sparling, 1983) and Eifelian (Cooper et al., 1942; Fagerstrom, 1966). Rickard (1984) places the question to rest by placing the Amherstburg, Lucas and Sylvania in the Eifelian.

The Columbus is thickest in central Ohio, where the Bellepoint is the only member used in descriptions (Sparling, 1988). The Columbus thins northward, however, to a point around Sandusky, Ohio, where the Bellepoint is only two meters in thickness. In nearby areas, it, along with the Delhi, may be absent (Stauffer, 1957). The Delaware may thicken, slightly, northward (Schuchert, 1943). However, the relative thickness of these units may be misleading since members are rarely distinguishable from one site to the next and the positioning of their contacts may often be arbitrary.

\section{Depositional History}

The Columbus depositional environment began as a clear, open sea, but the presence of ripples toward the top (Sparling, 1988) indicates that the sea was shallowing through time. It was long thought that during Delaware time, the seas of Ohio were very shallow, though 
no ripple marks had been reported (Westgate and Fischer, 1933). Recent studies from other regions, however, indicate that the environment of deposition was deepening.

Westgate and Fischer (1933) chose to ignore evidence for a deep-water origin of the Delaware Limestone. In addition to the lack of ripple marks, they reported bone beds devoid of anything but phosphatic material and eolian minerals, high concentrations of mud, pyrite, faunas dominated by a few species, and shaly partings. All of these characteristics are indicative of deeper waters.

The brown Delaware is a muddier unit than the Columbus (Sparling, 1988), only about 40-60 percent pure (Forsyth, 1988). The less favorable environment is reflected in the decrease in assemblage diversity. Within the formation, single species of several invertebrate groups, particularly pelecypods, brachiopods and tentaculitoids, may be common (Wells, 1947). The occurrence of bone beds, crinoidal sands, and shaly partings was thought to indicate a shallow-water deposition (Westgate and Fischer, 1933), though, as of this study, it is now known that the deposits are transgressional lags.

Sparling (1988) thought that the Columbus might have been deposited in conditions similar to that of the Onondaga, cooler waters of a broad, subtropical shelf. Stauffer (1957) and Taylor and Camp (1986) were in agreement, however, that the Eifelian waters of central Ohio were warm, shallow, gently agitated, normal and well-luminated, and were located on a carbonate shelf on the western side of the Appalachian Basin (Koch, 1981).

Taylor and Camp (1986) thought that the Columbus formed during a transgressive phase of sea level that reached well into the Michigan basin. Their evidence for a transgression comes from a decrease in dolomite upsection, the increased thickness of the upper units in the north and the northward expansion of a basal coral zone (Sparling, 1988). The coral zone is 11 meters above the base in northern Ohio. Sparling $(1983 ; 1988)$ suggests that the transgression terminates just below the first of a sequence of bone beds and an unconformity that mark the top of the Columbus. In order to accept the idea of a Columbus transgression, one would have to ignore ripple marks and tidalites that occur near the Columbus/Delaware boundary and the fact that no such structures have been reported from the Delaware. In addition, dolomite occurs throughout the formation, and the migration of the coral bed is the result of facies change, not a transgression. Sparling (1983) believed that the Sylvanian basal sandstone and the Amherstburg/Lucas complex were also transgressive, though in a southerly direction.

Stith (1998, personal communication) provided the Wagner Quarry Company with a report on the hydrocarbons present in some facies of the Columbus. Faint to pronounced hydrocarbon odors are not uncommon and are usually observed with no other sign of petroleum. The presence of the hydrocarbons is a natural occurrence and not the result of contamination. He gave, however, no explanation regarding the origin of this fluid. The author of this paper observed petroleum seeping from the upper units of the Columbus in the Wagner Quarry just outside of Sandusky, Ohio. These may have led Swartz (1907; in Sparling, 1988) to believe that coal was present since there have been no other reports of coal in the Columbus.

The proximity of the Columbus to the Cincinnati arch may have affected the depositional history of the formation. Sparling (1988) thought that subtle tectonic changes in the arch may have caused local transgressive-regressive episodes that he observed in the microfacies. He also reported that the arch was the source of clays and silica in the 
formation. However, most studies comment on the purity of the formation and the scarcity of chert.

Faunal Studies

One of the more prominent features of the Columbus Limestone is the distinct coral bed of the lower units that may be over a meter in thickness (Stewart, 1938). Stauffer (1909, in Oliver, 1976) divided the Columbus into eight zones. The first two were the basal conglomerate and a zone with very few megafossils. The third was the coral zone and contained colonial species that also occur in the Edgecliff Member of the Onondaga Formation. Wicander and Wright (1983) reported a high abundance and diversity of wellpreserved chitinozoans and organic-walled microfossils in this zone.

In the nonfossiliferous zone of the lower Marblehead, the fourth zone, the abundance of microphytoplankton continued unabated (Wicander and Wright, 1983). The fifth through eighth zones are minor assemblage zones, but the eighth is a zone containing Eridophyllum, a coral taxon also found in the Moorehouse, though the coral was more common and more diverse in Ohio. Because the only occurrence of Eridophyllum in the Onondaga is in the Moorehouse, it provides an excellent correlation of the two formations. No colonial rugose corals have been reported from the Delaware (Oliver, 1976).

The bone beds within the Columbus-Delaware complex have been subjects of many reports. Wells $(1944,1947)$ reported four or five beds, mostly within the Delaware (Figure 8 ). The second, at the top of the Columbus, is the only one that extends throughout Ohio. These deposits were interpreted as current lag deposits, the result of shallow wave reworking. At the unconformity atop the Columbus, the fragments are found only in erosional depressions (Westgate and Fischer, 1933).

Bentley (1988) reported no large fossil remains from the bed at the ColumbusDelaware contact. Indeed, most of his samples were comprised of small scales, plates and teeth that required an electron microscope to be properly examined. In addition, Onychodus was the only taxon in his report that is also represented as museum specimens.

Nearly all of the fish fragments collected by Westgate and Fischer (1933) were broken, worn and abraded, probably due to wave action. Brachiopods and corals also showed signs of rounding, and ripple marks were visible in the units just below the bone bed. They contradicted Newberry's (1889, in Westgate and Fischer, 1933) claim that organic material indicated a deep-water deposition and the rounding was due to mastication. However, Leonard (1996) found bone beds that were transgressional lag deposits, rather than the result of normal current reworking at the base of the North Vernon Limestone in Indiana, a unit correlable with the Delaware (Shaver, 1985). It is now clear that the bone beds of the Delaware also represent flooding surfaces rather than normal current hash or fecal consolidation.

Because of the lack of macrofossils, the poor condition of the fragments and the timecondensed nature of the deposit, these bone beds were not included in the paleontological section of this study. The reports of the beds, however, do provide some information about the depositional environment that may be useful. Hadrophyllum d'orbignyi is often the only other fossil associated with these beds and is most often found in the impoverished faunas. Pyrite may also be found (Wells, 1944). 
The thin basal coral bed at the base of the Columbus has been reported as Edgecliffcorrelative (Mesolella, 1978). Because the Tioga Bentonite separates the Columbus and Delaware as well as the Moorehouse and Seneca, the Delaware and Seneca are correlative (Oliver, 1976) and the Moorehouse, Nedrow and Edgecliff equate to the Columbus (Mesolella, 1978; Patchen et al., 1985).

Formations in Indiana, Illinois, and Michigan are correlative with the Columbus and the Onondaga (Oliver, 1981; Shaver, 1985). Thirty-five percent of the invertebrate fauna of the Jeffersonville Formation of Indiana and 49 percent of the Grand Tower Formation of Illinois and Michigan are found in the Columbus or Onondaga. Savage (1910) reported that the fish fauna of Ohio did not extend to those western regions. However, Rhynchodus secans?, Macropetalichthys sullivanti and Ohioaspis tumulosus have been collected in both the Jeffersonville and Columbus Limestones (Denison, 1978).

\section{RESULTS}

\section{Research Sites-Onondaga Limestone Site}

The Buffalo Crushed Stone Quarry was chosen as the primary site for the Onondaga Formation. It is located in the southwestern corner of the Lancaster, New York 7.5 minute quadrangle on Como Park Road, just east of the New York State Thruway (Interstate 90) and the junction of Como Park Road and Bennett Road (Figure 9A). It is in the town of Cheektowaga, a suburb southeast of the city of Buffalo. Global positioning data indicate a location of $42^{\circ} 53^{\prime} 45^{\prime \prime} \mathrm{N}$ latitude and $78^{\circ} 44^{\prime} 20^{\prime}$ ' W longitude. The quarry is presently divided into halves. The eastern half is where most of the current quarry activity occurs, but the western half is largely abandoned and provides an excellent view of the Onondaga (Figure $10)$.

According to the quarry manager, Ron Hope, the quarry has undergone several name changes as ownership has changed. These names include Bennett Quarry, Buffalo Cement Quarry and the Federal Crushed Stone Quarry (FCS Quarry). The change of ownership and name accounts

for most of the site localities attached to specimens at the Buffalo Museum. Quarrying began around the turn of the 20th Century.

Terraces were built in conjunction with switchbacks in order for quarry vehicles to work under stable conditions and are best developed on the south side of the quarry. The surfaces of each member made a perfect driving surface, so the terraces usually represent contacts (Figure 11). The switchbacks provide excellent exposure to the entire section, so the majority of study and sampling occurred on the south side of the quarry.

\section{Stratigraphy and Lithology}

The base of the quarry, the Edgecliff Member, consists of a coarse, medium-gray, fossiliferous rock. It is a packstone with a matrix of echinoderm plates. A report provided by the quarry indicated that it was a dolomite. However, the light color and well preserved rugose corals indicated that there was very little dolomitization. Megaripples are visible across the floor of the quarry indicating an environment of considerable energy. These 
sedimentary structures are uniform in shape and distribution and measure about 15 centimeters in height and 3 meters in width with a wavelength of 3-10 meters (Figure 12A).

The first unit above the Edgecliff is a very dark, very fine-grained, well-indurated mudstone about six meters in thickness (Figure 2). Where the surfaces of crystal grains were visible, they were very small. The chert is very dark, though a lighter rim may be seen in both weathered and fresh samples. The chert commonly fills the interiors of burrows (Figure 12B). The fact that these burrows are not collapsed may indicate the near syndeposition of the limestone and chert. There were no fossils other than a few, small, recrystallized rugose corals and two Phacops trilobites.

Above the dark, argillaceous unit is another fine-grained unit (Figure 2), but this unit is light gray in color and the chert is almost white. The chert appears to be more bedded than the unit below. Organic grains are common, but do not alter the light color. Fossils are rare. This unit and the unit below are considered the Clarence Member, based on the abundance of chert and the scarcity of fossils. The lower, darker subunit may reflect conditions of the Nedrow in central and western New York, whereas the lighter unit above indicates a change in the depositional environment that only occurred in the western part of New York.

After 3.3 meters, the unit light in color and with light colored chert gives way to a 2.7 meter bioherm of tabulate corals and a few colonial rugose corals surrounded by dark chert (Figures 2 and 12C). The rugose colonies may be 20-25 centimeters in diameter, but the tabulates may exceed 80 centimeters in diameter. This feature is traceable across the 175 meters wide quarry. The unit above the bioherm $(5.7 \mathrm{~m})$ marks a return to lighter chert, though the matrix is slightly darker and coarser than the unit below the reef. Fossils are common and are often overturned. Hummocky cross beds are present in the more massive sections. Stylolites are very common and many of the fossils have been recrystallized.

The light color of the limestone and the chert in the units surrounding the reef is indicative of the Clarence. The unit below the reef is most indicative of the Clarence due to its lack of fossils, though the rocks above the reef contain enough chert to warrant their placement within the member. This unit is transitional with the overlying Moorehouse.

At 17.7 meters above the floor of the quarry, the Moorehouse begins (Figure 2). It begins as a medium-dark gray, coarse, 3.3 meter limestone with light chert and ends in 16.7 meters of darker, finer limestone with dark chert, shaly partings, and pyrite nodules. The only difference between the rocks of the lower unit and those of the upper Clarence below is the larger grain size of the lower Moorehouse. The bottom-most rocks of the upper section are nearly identical to the rocks sampled on the floor of the quarry and represent a return to the conditions of the Edgecliff. Overall, the Moorehouse is fossiliferous throughout, although the fossils, mostly brachiopods and rugose corals, tend to be most common in certain levels. Coupled with overturned fauna, concentrations of fossils at certain levels may indicate storm deposits.

The north side of the quarry is the only place where the Seneca is exposed. The three meter section is separated from the Moorehouse Member by the Tioga Bentonite. The Seneca is a very light colored rock, though brown micrite may be present, and is very coarse. Crinoid columnals are small and seem to be limited to a 2-3 centimeter horizon half a meter above the bentonite. Fossils are usually broken and abraded. Chert is not common, but it is dark when it occurs. Laminae are visible a few centimeters above the crinoidal layer. The pink Chonetes zone was never observed during the course of this study. 
Brett and Ver Straeten (1994) considered the Clarence a facies of the Edgecliff, stating that it rested above the Edgecliff and interfingered with the Nedrow in the Leroy region. However, they did not observe rocks further west. They delineated the Edgecliff as the unit extending from the base of the Onondaga to the first shaly beds of the Nedrow. In the Cheektowaga area, however, there is no Nedrow, so the Edgecliff cannot be defined as they have done.

The Clarence of the Cheektowaga Quarry rests sharply above the Edgecliff below. The Edgecliff is very coarse, light colored and fossiliferous. The Clarence above, however, is very fine-grained, dark in color and not fossiliferous, very similar to the lithology of the Nedrow. Brett and Ver Straeten (1994) note the same lithologies in their description. They report of a $20 \mathrm{~cm}$ dark, barren limestone as the base of the Nedrow. This unit is very similar in character, though not as thick, as the lower unit of the Clarence at Cheektowaga.

The dark, barren limestone of Brett and Ver Straeten (1994) becomes a medium-gray wackestone with sparse fossils and dark chert that alternates with a light-gray packstone with dark chert. This description is also valid for the transitional units of the upper Clarence in the research site of the present study. In addition, they describe a $20-40 \mathrm{~cm}$ coral rich layer that gives rise to a $70 \mathrm{~cm}$ nonfossiliferous layer within the Nedrow. They include all of these lithologies within the Nedrow. The only difference in their description and in Figure 2 of this paper appears to be the presence of dark chert in the dark, barren unit of Cheektowaga and the thicker nature of the westernmost units. This contradicts Brett and Ver Straeten's (1994) hypothesize that the Clarence facies may thin in the Buffalo area.

In Cheektowaga, the Clarence grades slowly into the Moorehouse. The upper units of the Clarence are similar to the Moorehouse and the lower units of the Moorehouse are very Clarence-like. Considering the sharp contact of the Clarence with the Edgecliff below and the gradational nature of the Clarence with the Moorehouse, it seems more reasonable that the Clarence could be the basal facies of the Moorehouse rather than the terminal facies of the Edgecliff as suggested by Brett and Ver Straeten (1994).

Brett and Ver Straeten (1994) state that their Clarence facies is very similar to the shale beds of the upper Moorehouse that are traceable across the state. These beds are not observed in Cheektowaga, though the upper Moorehouse contains numerous, thin shaly partings. The conditions of the Clarence were not repeated in the highly fossiliferous upper Moorehouse, although there was a return to deeper waters. This could indicate that the dark unit of the Clarence was a barrier deposit that was overcome by a sea level rise during the time of the upper Clarence. However, no evidence of a barrier has ever been observed or reported. The Clarence of western and central New York are both marked by a major marine flooding surface and rest above shallower units of the Edgecliff, though Brett and Ver Straeten (1994) never propose an origin for the dark-colored, fine-grained Clarence facies.

Brett and Ver Straeten (1994) delineate the base of the Moorehouse as the sparsely fossiliferous unit above two shale beds near the top of the Nedrow. In Cheektowaga, there is a thin sparsely fossiliferous unit at the base of the Moorehouse, but it does not follow any shale beds. They report a shallowing in the lower Moorehouse followed by a deepening in the upper units. This shallowing is consistent with the findings of the present study.

However, Brett and Ver Straeten (1994) seem to contradict themselves when they state, "Chert is generally uncommon to rare in the dark shale facies (of the Nedrow) but is relatively more abundant in laterally equivalent, more carbonate-rich facies of the member." If the Clarence was the lateral equivalent of the Nedrow, this statement would hold true. If 
the Edgecliff is the lateral equivalent, however, this is contradictory, because the Edgecliff is reported as only locally cherty by Brett and Ver Straeten (1994) and not cherty in the west by Feldman (1994). Oliver (1954) reports that the Edgecliff is cherty and interfingers with the Nedrow in the east, but there is an abrupt change in the west where the Edgecliff is overlain by a unit consisting of mostly chert.

\section{$\underline{\text { Thin Sections }}$}

Thin sections (Table 2) were made in order to better describe and understand the units of the Onondaga and Columbus limestones. Figures 2 and 4 show the location of the thin section samples using the numbers assigned to each.

The floor of the Cheektowaga quarry is definitely not dolomitic as claimed by the quarry report (thin section 8). Not only did the sample not stain in a dolomite test, not a single dolomite rhombohedron was seen in thin section. In thin section, the Edgecliff Member rocks were grainstones, usually composed of small echinoderm bits. The preponderance of small skeletal fragments supports the idea that it was a high energy environment. Larger grains include trilobite body segments and spines, brachiopods, bryozoans and ostracods. There are many small crystals of chalcedony, and sparite has filled in some void space. Organic matter, probably pyritized, was common as well. Chert was not observed in outcrop, but only the very top of the unit was accessible and sampled.

As expected, the base of the quarry, the lowest unit of the Clarence Member, is very dark and very fine-grained, and microstylolites and organic matter are common (thin section 9). Very small chalcedony grains are common, and the chert is very dark. Sparry cement may fill void space. The only fossils are represented by bits of trilobites, echinoderms and bryozoans, most of which have been bored by postdepositional bioeroders. Higher in the basal unit, grain size increases and the rock becomes more fossiliferous (thin section 10). Dolomite rhombohedra appear as do brachiopods, lacy bryozoans, ostracods and the only occurrence of gastropods observed in this study of the Onondaga.

Just above the basal unit of the Clarence, the rock abruptly becomes light in color with light chert (thin section 11). In thin section, the matrix of this packstone consists of mud and chert with several small grains of chalcedony and organic material, though macroremains are not common. A few large brachiopods and crinoid columnals are visible and bits of bryozoans are common. Most of the fauna is broken into small pieces and the larger forms are often infilled with sparite. However, the most significant fossil component is calcareous algae, a relatively common and large component of this unit (Figure 13). The algae may be encrusting or free-living, and its taxonomy is unclear. Regardless, this find, and a report from the Edgecliff by Bruner and Smosna (2002), contradicts previous reports that algae are absent in Onondaga rocks. The presence of algae indicates that the Clarence, the deepest unit of the formation, was within the photic zone.

A few centimeters upsection, the character of the packstone remains the same, though trilobites and ostracods become more common and the first coral appears (thin section 12). This unit appears to have been an area high in energy, as were the units of the quarry floor.

Near the top of the Clarence, there is very little change in the texture of the rock in thin section and it is still a packstone (thin section 14). Only the presence of numerous dolomite rhombohedra and bored fossils differentiates this rock from those in the Clarence below the coral layer. 
A small fine-grained horizon with few fossils, but many ostracods marks the base of the Moorehouse (thin section 15), but two meters above the Clarence, within the Moorehouse, the rock becomes a grainstone. This grainstone is transitional between the Clarence and the Moorehouse. There are a few chalcedony grains, and echinoderm plates are very common and very large. Bryozoans, including lacy forms, brachiopods and trilobites are also large. Microstylolites are common and where there is mud, it is very dark. The high incidence of bored fossils, some to the brink of recognition, indicates that this may be a deposit that rested on the bottom for some time. Grainstones and muddy beds alternate as one might expect in a transitional zone.

Two-to-three meters below the Tioga Bentonite, the rock remains a grainstone (thin section 17), though the echinoderm debris is smaller. Trilobites and bryozoans, however, are still large. This unit marks the first presence of tentaculitoids in this study of the Onondaga. Chert was not observed in thin section due to random sampling, though dark chert was collected from this section.

A meter above the Tioga Bentonite, the Seneca is a grainstone (thin section 18), but there is much less organic material than in the upper Moorehouse rocks, below. Trilobites and bryozoans are large and the only phosphatic debris found in this thin section study, a spine, is found here. No chert is observed in thin section, but numerous chalcedony grains are visible.

\section{Research Site-Columbus Limestone Site}

The Martin Marietta Delaware Quarry just west of the town of Warrensburg, Ohio, was chosen as the primary study site for the Columbus Limestone. The quarry is named after the nearby town of Delaware, or Delaware County, but there is no Delaware limestone present in the quarry. It is located near the center of the Ostrander quadrangle on an unnumbered local road located halfway between the junctions of Highway 36 and State Road 257, and State Road 37 and State Road 257 (Figure 9B). Global positioning system data indicate a location of $40^{\circ} 18^{\prime} 00^{\prime} \mathrm{N}$ latitude and $83^{\circ} 10^{\prime} 30^{\prime}$ 'W longitude. Additional information on the Columbus and Delaware limestones came from the Wagner Quarry in Sandusky (Figure 6).

The exposures of the Warrensburg quarry are most accessible on the northern and southern sides where mining activity is at a minimum. The maximum exposure is on the northern side where $\mathrm{ca}$. 20 meters of the Columbus is exposed. Most of the study and sampling occurred on the northern side.

\section{Stratigraphy and Lithology}

The first seven or eight meters of the Warrensburg quarry are a gray brown, very finegrained limestone (Figure 6) most similar to descriptions of the Bellepoint Member. A small layer of corals four meters above the quarry floor and a $20 \mathrm{~cm}$ section of infilled burrows just below it, are the only accumulations of fossils in the unit. Above the coral layer, there are a few scattered rugose corals, but there is very little below. This unit extends below the floor of the quarry.

A meter-thick unit of colonial rugose corals, stromatoporoids, and solitary rugose 
corals rests atop the basal layer (Figures 6, 14, 13). Many of the rugose coral and stromatoporoid colonies are greater than 0.5 meters in diameter, some over one meter. This unit is traceable across the quarry, but was not observed in quarries in Columbus or Sandusky. Large forms are in growth position, but smaller ones are often on their sides. The numerous, large stromatoporoids that adorn a small garden outside of the quarry are presumed to have come from this layer (Figure 15).

Above the coral unit is another two meters of gray-brown limestone, largely devoid of fossils (Figure 6). This unit, however, is slightly coarser than the similar unit below the coral layer. The grains are composed of fossil debris, mostly echinoderm fragments.

Eleven meters above the floor of the quarry is a coarse, very fossiliferous unit about six meters thick and with numerous solitary rugose corals and abundant gastropods (Figure 6 ). The gray color is similar to that of pure limestones. The unit grades upwards into a finer, browner limestone, and brachiopods become more dominant than rugose corals. It does not fit the descriptions of the Marblehead or the Ebersole, the two units normally placed above the Bellepoint.

Above this unit is a coarse, very fossiliferous shell hash about 3 meters in thickness. Nearly all of the fossils are disarticulated crinoids columnals. This layer is more resistant to erosion than the unit below and forms a ledge protruding from the quarry wall.

On the south side, an additional two meters is exposed above the hash unit (Figure 6). This unit is a very coarse, fossiliferous limestone that looks very much like the rocks of the lower Moorehouse. It is lighter in color and slightly finer than that member, but several large crystal faces are visible. This unit represents a return to deeper waters.

Chert was never observed in place at Warrensburg, though light chert was found in talus below the outcrop. Stylolites were common in all units, and pyrite was found in the coral layer and where brachiopods dominate.

The units of the Columbus Limestone in Warrensburg do not resemble the classic alignment of the Bellepoint, Ebersole and Delhi members, though the bottom layer is certainly characteristic of the Bellepoint. The rock is much more homogenized, with a general trend to coarsen upward. At the top of the sequence in the Martin Marietta Quarry in Columbus, Ohio, the small laminae of tidalites were observed, indicating that the lower, finer, less fossiliferous layers were deposited in deeper waters and there was a gradual, consistent shallowing upwards. The tidalites rest above slightly finer rocks, probably deposited at the same time as the upper units in the Warrensburg Quarry.

In Sandusky, the classic members, sans the Bellepoint (Figure 6), are obvious, but further south, the lower unit, including the coral layer, should be considered the "lower Columbus", or the Bellepoint, and the fossiliferous, coarse units above, the "upper Columbus".

Leonard (1996) examined the sequence stratigraphy of the Jeffersonville Limestone in Indiana, a unit correlative with the Columbus (Shaver, 1985; Figure 16). The base consisted of a shallow-open or low-energy marine unit with biostromal tabulate, colonial rugose and solitary rugose corals, and stromatoporoids. It graded upwards into a higher energy boundstone. This unit, allo-unit 1 , was overlain by a lagoonal wackestone, allo-unit 2 , that contained brachiopods, gastropods, and rugose corals. The top of allo-unit 2 was interpreted as a major flooding surface, because the next unit reverted back to a shallow-open marine facies. In this unit, allo-unit 3 , rugose corals became less common upsection due to 
the presence of habitats more favorable for brachiopods. Near the top of the unit, the Tioga Bentonite was deposited. The next unit, the North Vernon Limestone, was a deeper open marine facies with scattered bone beds. These bone beds were interpreted to be the result of a reduction in carbonate accumulation due to the rise in sea level.

In the Columbus, the basal unit is also a low energy marine facies, though fossils are largely limited to a single biostromal unit. The unit above is very similar, only a bit coarser indicating a slight increase in energy. This unit is similar to Leonard's (1996) allo-unit 1, though the water depth of the Columbus unit may have been a bit deeper, i.e., the carbonate platform of the Columbus Sea may have been deeper in southern Ohio than the Wabash platform was in southern Indiana (Figure 1B). The basal unit of the Columbus is interpreted as being slightly deeper based on the near absence of fossils and the lack of evidence for an overlying lagoonal deposit.

Leonard's (1996) next unit, allo-unit 2, is lagoonal with rugose corals and gastropods. The next unit in the Columbus, however, is not very muddy and is very coarse, but does contain the only gastropods found in the section. Perhaps, a barrier formed in Indiana, leading to lagoonal conditions, while conditions remained more open, but still shallowing upwards, in Ohio.

Allo-unit 3 is the result of a flooding event that brought shallow-open marine facies back to the section. Within this unit, fossils grade from rugose corals to brachiopods upsection. The same thing occurs within the Columbus, though within the same lithofacies as the unit below. The change in dominance from rugose corals to brachiopods is a recognizable character of the facies change, as it has been reported in Indiana (Leonard, 1996), Ohio, and Poland (Sarnecka, 1988) within coeval units. The flooding event was probably not as pronounced in Ohio because the change in lithology was not as extreme as it was in Indiana, perhaps further evidence that the Columbus was deposited in deeper waters.

The next unit of the Columbus is the very coarse, very fossiliferous hash layer. It represents normal accumulation in a shallow, high-energy wash zone and indicates a continuing shallowing of the Eifelian Sea. This hash layer was not observed in Indiana. If the hash layer represents shoreline conditions, Indiana would have been exposed to subaerial exposure during this time. A tentative shoreline unconformity is reported by Leonard (1996) atop allo-unit 3 (Figure 16).

The North Vernon Limestone is the next unit above Leonard's (1996) allo-unit 3. It is very similar to the Delaware in that it possesses phosphatic bone beds and becomes more argillaceous upsection. There is no doubt that, like the North Vernon, the Delaware represents a series of flooding events that affected both Indiana and Ohio. Each of the bone beds represents a flooding surface. The bone beds atop the Columbus (Wells, 1944) indicate that minor flooding events were already occurring prior to the major event that marks the beginning of the Delaware.

The presence of the Tioga Bentonite is the best tool in the correlation of the Columbus/Delaware with the Onondaga. Koch (1981) considered the Delaware Limestone a basin to shelf equivalent of the Seneca Member of the Onondaga. They are now known to be coeval, and their depositional histories similar. However, within the Jeffersonville Limestone, the Tioga is too thin and too easily confused with other bentonites to be of use in correlating units (Leonard, 1996). Other reports, however, have supported the correlation of the North Vernon to the Delaware and both with the Seneca (Patchen et al., 1985; Shaver, 1985). 


\section{$\underline{\text { Thin Sections }}$}

In thin section (Figure 17), the basal unit (Figure 6) is very muddy and very fine grained (thin section 1). The largest grains observed, recrystallized calcite crystals, were only about $0.125 \mathrm{~mm}$ in length. However, distinguishable fossils were present. Several grains of chalcedony, and dolomite occurred throughout the section, especially in certain areas. Organic matter was common.

At the microscopic level, the matrix of the coral layer (thin section 2), the next unit upwards, proved to be mostly calcite crystals, usually around $0.025 \mathrm{~mm}$, but occasionally echinoderm plates as large as $0.5 \mathrm{~mm}$ were observed. The presence of an echinoid spine indicates that there were non-crinoid echinoderms present. In addition to the echinoderms and corals, both small and large, there were bits of trilobites and brachiopods and large pieces of bryozoans. Some of the corals were slightly silicified, but there were no chalcedony grains. Dolomite was rare.

Macroscopically, many of the corals, particularly the solitary rugose, were not in growth position. Smaller forms were commonly so bored that they blended into the matrix. Considering these aspects and its fossiliferous nature, the unit probably formed in a highenergy environment. Much of the non-coral fossil debris may have been brought in from surrounding areas by fairly substantial currents. Larger corals are in growth position, indicating that energy levels were not high enough to displace them.

Above the coral layer, the nonfossiliferous zone marks a return to less than ideal conditions, probably deeper waters (thin section 3). Like the basal layer, this unit is a mudstone with a few chalcedony grains and numerous dolomite rhombohedra. Echinoderm debris are the only fossils present.

The fossil zone above the second nonfossiliferous layer is a very coarse grainstone with a sparitic cement (thin section 4). It appears that the sparite has filled in space vacated by dissolved fossils. There are a few grains of chalcedony and numerous dolomite rhombohedra, though the dominant grains are fossils. Crinoid columnals can be as large as 1.0 and are often bored. Bryozoans are also large and common, with trilobites, brachiopods, and ostracods also present. Tentaculitids are very common and may be $0.75 \mathrm{~mm}$ in diameter. Two meters above, the rock is similar (thin section 5).

The lower section of the hash layer is very similar to the layer below (thin section 6). The matrix is mostly mud, with some sparry cement, and the rock is very fossiliferous. There are a few chalcedony grains, dolomite is common, and the fossils are highly bored. The presence of a single coral is the only difference in faunal diversity, though the number of fossils is considerably higher.

Three meters higher, however, the hash layer changes a bit (thin section 7). The matrix is nearly entirely whole fossils surrounded by a sparitic matrix. There are many grains of chalcedony, but very few dolomite rhombohedra. Echinoderms, brachiopods, bryozoans, and tentaculitids are numerous and large. At least one gastropod was observed. Microstylolites and organic grains are common. 
Fishes of the Eifelian

A total of 244 specimens were examined at the Cleveland Museum of Natural History, although 381 were counted by a volunteer prior to this study. The difference was fragments that were unidentifiable and deemed useless for this study. A total of 163 specimens were examined in the Buffalo Museum of Science, eight of which were type specimens. Specimens associated with the prefix, "BW-3" are from the Baldwin-Wallace Collection at the Cleveland Museum of Natural History. Those with the letter, 'E', are from the Buffalo Museum of Science.

Most of the fossils are well preserved, but represented by isolated plates/bones. They show some signs of wear and current abrasion, but they usually appear to be whole elements. However, rarely are two or more elements found articulated as they related in life. The lone exception to this is Macropetalichthys, in which full head shields and anterior ventrolateral plates with spines are the most common specimens of the taxon in the collections. Illustrations of fully articulated specimens from Australia were used for comparison, and helped in determining the identification of many specimens, especially those that were misidentified or were never identified.

Petalichthyids, Ptyctodus, dinichthyids, Astrolepis, ptyctodontids, Rhynchodus, acanthodians and Onychodus (Thomson, 1980), the major taxa of the Eifelian of North America, were strictly marine taxa, though Astrolepis has been collected in the Escuminac Formation of Quebec, a brackish lagoonal deposit (Long, 1995).

Both agnathans and gnathostomes were present in the Eifelian of North America, though no agnathans were found during the course of this study. The jawless fishes are usually reported from bone beds (Bentley, 1988), and will not be discussed further. The Devonian is often referred to as the Age of Fishes because it is the only period in which agnathans and the four groups of gnathostomes, the placoderms, the acanthodians, the osteichthyans (sarcopterygians and actinopterygians) and the chondrichthyans are all present in significant numbers. Chondrichthyan fishes were not found during this study and will not be discussed further. One species of sarcopterygian and one species of acanthodian are the only non-placoderm taxa present. Of the seven placoderm taxa, only one is not a ptyctodont. In North America, ptyctodonts first appeared in the Eifelian. They dominate that stage and are highly diverse in the Givetian and Frasnian. Arthrodires become the most diverse and abundant group of placoderms after the Eifelian.

About 61 species of fish are reported from the Eifelian, and 16 of these species are from North America (Carr, 1995). The overwhelming majority of Eifelian fishes found outside of the United States are arthrodires and only two are ptyctodonts. Ptyctodonts are the most common Eifelian fish fossils in eastern North America, whereas arthrodires are relatively rare.

Due to a lack of intermediate taxa, phylogenetic relationships of the Devonian fishes are highly speculative. It is unknown which of the four gnathostomes are most closely related or from which ancestral agnathan lineage they derived (Long, 1995). Therefore, no discussion of basal fish interrelationships will follow. However, the petalichthyids and the ptyctodonts are consistently placed as an outgroup of the phyllolepids + arthrodires within the placoderm clade (Figure 18). This relationship is crucial to understanding the Eifelian fishes of North America and will be discussed periodically throughout the remainder of this paper. 
Fishes will be discussed in phylogenetic order and the associated plates will follow the discussion. Within the ptyctodonts, however, individual species will be discussed in order of importance to this study. All taxa appearing in tables will be listed in alphabetic order for easier reference. Figure 19 illustrates the dimensions of dental plates as they are discussed in the text.

Classification of Eifelian Fishes found in the Collections of the Buffalo Science Museum and the Cleveland Museum of Natural History (names and phylogenetic order follows Denison, 1978; Denison, 1979; Nelson, 1994).

Subphylum Vertebrata (Craniata)

Superclass Agnatha; remains reported, but none observed in the field or in museums during the course of this study.

Superclass Gnathostomata

Grade Placodermiomorphi

Class Placodermi

Order Petalichthyiformes

Family Macropetalichthyidae

Macropetalichthys sullivanti Norwood and Owen (1846)

Order Ptyctodontiformes

Family Ptyctodontidae

Deinodus bennetti Hussakof and Bryant (1919)

Deinodus ohioensis n. sp. Martin (2002)

Palaeomylus frangens Woodward (1891)

Ptyctodus reimanni Pander (1858)

Rhynchodus secans Newberry (1873)

Eczematolepis fragilis Miller (1892)

The following placoderm taxa have been reported from the Eifelian of North America, but were not observed during this study.

Palaeomylus crassus Newberry (1873); not found in the museum collections, but is reported from the Columbus and Delaware (Denison, 1978).

Ptyctodus punctatus Eastman (1907); not found in the museum collections, but is reported from the Onondaga (Denison, 1978).

Asterosteus Newberry (1875); not found in the museum collections, though specimens are incorrectly labeled as Asterosteus.

Ohioaspis tumulosus Wells (1944); composed of small tesserae similar to that of Asterosteus and may be of the same genus (Denison, 1978). It is not likely that the tesserae could represent the small elements of an agnathan as thought by Bentley (1988). It was not observed in any of the museum collections.

Protitanichthys fossatus, Eastman (1907); not found in the museums, but has been reported from the Delaware (Denison, 1978).

Woodwardosteus (Liognathus) spatulatus, White and Moy-Thomas (1940); not found in the museums, but has been reported from the Delaware (Denison, 1978). 


\author{
Grade Teleostomi \\ Class Acanthodii \\ Order Ischnacanthiformes \\ Family Ischnacanthidae \\ Machaeracanthus peracutus Newberry (1857) \\ Class Sarcopterygii \\ Order Onychodontiformes \\ Family Onychodontidae \\ Onychodus sigmoides Newberry (1857)
}

Petalichthyids

The Petalichthyidae are a group of marine placoderms that are likely a sister taxon of the ptyctodonts (Carr, 1995). Macropetalichthys was first described by Norwood and Owen in 1846. Synonyms include Heintzaspis, Physichthys, Agassichthys, and Ohiodorulites (Denison, 1978; Tables 5, 6). Dermal plates and associated spines belonging to the species Acanthaspis armata are considered the ventral and lateral plates and pectoral spine of Macropetalichthys (Denison, 1978). The species of Macropetalichthys found in the Buffalo and Cleveland museums is M. rapheidolabis (A. armata on many of the museum specimen cards), though specimens labeled M. sullivanti also appears in the Cleveland collection (Denison, 1978). M. rapheidolabis is synonymized with M. sullivanti in this paper.

The original description of Macropetalichthys (Norwood and Owen, 1846) was based on large, articulated head plates (reconstructions on Plate 1A-B, D). The broad head, up to $25 \mathrm{~cm}$ in length, tapered gradually anteriorly to a broad snout. The head is dorsoventrally compressed and the eyes would have rested about one-half the way up the head and been oriented upward. The dermal bones may be slightly tubercled, and the tubercles are either concentrically or irregularly arranged (Denison, 1978; Plate 1C). The tubercles on the spines of Macropetalichthys, particularly toward the tip, are arranged in a series of striae and are much smaller in diameter than another tuberculated fish, Deinodus. The tubercles of Deinodus are important in its identification and will be discussed in further detail later.

Many of the Macropetalichthys in the museums are the dorsal aspect of complete or nearly complete crania. Spines, anterior ventrolateral plates and anterior lateral plates labeled as "Acanthaspis armata" comprise the remainder. However, no other post-cranial bones and no dental plates are cataloged. Petalichthyid gnathal elements have never been found anywhere in the world (Dineley and Loeffler, 1993), but it seems likely that some of the dental and dermal plates found in the same rocks, usually assigned to a ptyctodont form genus, belong to Macropetalichthys.

There are numerous dental plates in the museums that could have been derived from a petalichthyid with a $25 \mathrm{~cm}$ head, and most of the crania of the museums are less than $20 \mathrm{~cm}$ in length. Because ptyctodonts and petalichthyids are both usually an outgroup of the arthrodires (Figure 18), the ptyctodont jaw form may represent the plesiomorphic (ancestral) condition and be very similar to that of Macropetalichthys. Most Eifelian ptyctodonts are form genera based only on jaw plates, so any of the fossils of ptyctodonts known only from dental plates could represent the jaws of Macropetalichthys.

Specimen E17945 (Plate 3E) is labeled as Macropetalichthys, but it is not a cranial plate. The specimen card indicates that the collector thought this to be the dental plate of 
Macropetalichthys. However, closer examination reveals that the specimen is actually the jaw of Ptyctodus, a ptyctodont.

Based on the flattened nature of the head and the orientation of the eyes, it is likely that Macropetalichthys lived on or near the sea bottom. Dorsoventrally compressed skulls with dorsally positioned eyes are characteristics of benthic forms. These features allow them to detect prey or predators without wasting valuable energy by actively swimming above the sea floor (Denison, 1978).

Because no dentary plates are associated with any of the known petalichthyids (Dineley and Loeffler, 1993), its feeding strategies remain unknown. The most common unassigned dentary plates in the museums are elongated, narrow structures that could be capable of crushing, but seem best suited for shearing. If these elements belong to Macropetalichthys, the fish could have been an ambush predator that fed on other benthic fishes. Alternatively, Macropetalichthys could have been a filter or detrital feeder with very reduced dental plates. This would explain the absence of petalichthyid gnathal elements in the fossil record.

The Onondaga specimens of Macropetalichthys came from the units of the upper and lower Moorehouse and the Seneca, and the Columbus specimens from the upper Columbus and Delaware. The lower Moorehouse, the Seneca, and the upper Columbus are characterized by shoals, but are surrounded by deeper waters. The Delaware and upper Moorehouse are those deeper waters. Macropetalichthys occurs in many of the same horizons as Onychodus, a sarcopterygian discussed later, so it may have had a similar life habit. The presence of large numbers of Tentaculites and the coral Hadrophyllum in the matrix of several specimens supports the interpretation of a deeper water habitat.

Macropetalichthys sullivanti is considered a junior synonym of $M$. rapheidolabis. Denison (1978) places Newberry's (1857) Agassichthys sullivanti with M. rapheidolabis, but does not recognize Newberry's 1873 description of M. sullivanti. Newberry's specimen is very important. As he acknowledged (Newberry 1873), the M. rapheidolabis type specimen of Norwood and Owen was imperfect and poorly illustrated, and its description was vague and erroneous. In addition, the type specimen was lost sometime before 1873. An erroneous description and a missing type specimen make the description of Macropetalichthys rapheidolabis invalid.

In the absence of a type specimen and considering the inaccuracies of the original description, $M$. rapheidolabis should be considered a nomen nudum since there is no type specimen representative of the species. The specimens collected for the Cleveland and Buffalo museums should be referred to as M. sullivanti. "Macropetalichthys rapheidolabis" was probably assigned to a few specimens by early workers and perpetuated by later collectors. If it is a legitimate taxon, lectotypes from Indiana need to be located and compared to $M$. sullivanti.

Ptyctodonts

Ptyctodonts become significant faunal constituents in the Eifelian, a single specimen in the Praghian the only earlier form (Carr, 1995), and evolved into one of the most intriguing and unusual of the placoderm orders (Dineley and Loeffler, 1993). The 14 taxa of Eifelian ptyctodonts increase to 31 by the Frasnian, but they became extinct at the end of that stage (Carr, 1995). Because these Eifelian ptyctodonts are poorly known and are usually 
form genera, there may be a great deal of synonomizing if better specimens are found. Of the 14 ptyctodonts described, ten are identified to species, and of these ten, eight are found only in the units of eastern North America. Goniosteus and Rhynchodus major, both found in Germany, are the only Eifelian ptyctodonts reported from localities outside of North America (Denison, 1978).

Ptyctodonts are usually small, but some forms were among the largest fishes during the Eifelian of North America. They differ from other placoderms to the point that their relationship is suspect (reconstructions on Plate $2 \mathrm{~A}-\mathrm{B}, \mathrm{D})$ ). Their teeth are usually modified as crushing plates and, relative to the other placoderms, there is a reduction in dermal bone. Because of these characteristics, ptyctodonts superficially resembled modern chimeras (Plate $2 \mathrm{C}, 5 \mathrm{E})$. It is unclear if the reduction of armament is a derived or ancestral trait, though the order is usually considered one of the most basal within the placoderms (Denison, 1978).

The family Ptyctodontidae is the only family recognized within the order Ptyctodontiformes. Unfortunately, only scattered remains, usually dental plates, are typically all that are available for study. Many species are recognized solely by these plates, and, therefore, represent form taxa. Only the collection of a few articulated and undamaged specimens, most from Australia, provides any information about the group.

Placoderms exhibit a high level of endemism (Carr, 1995) and the Eifelian of North America was a time of provincialism. The Onondaga, Columbus and Delaware faunas were part of the distinct Eastern Americas Realm (Boucot, 1988). Therefore, comparison to Australian specimens and specimens from other Devonian ages can only provide a rough clue as to the function of any given plate.

\section{Ptyctodus}

Ptyctodus was first described by Pander in 1858. Synonyms include Rinodus and Aulacosteus (Denison, 1978; Tables 5, 6). The specimens of Ptyctodus in the Buffalo museum were never assigned a specific name, but a specimen of Paraptyctodus reimanni, represented by a very similar dental plate, was. Denison (1978) observed that the specimen of Paraptyctodus, described by Carter in 1942, was indistinguishable from Ptyctodus and he synonymized the two genera, retaining the species "reimanni" for Onondaga forms of Ptyctodus.

Like other ptyctodonts, Ptyctodus is only known from detached dental plates. The tritoral (occlusal) surface is long, broad, and flat and is quite distinct from other ptyctodont dental plates (Plate 3). A beak-like projection may or may not be present anteriorly (Denison, 1978), and the anterior dorsum of the lower dental plate may form a cutting edge (Hussakof and Bryant, 1918).

The broad and flat nature of the dentary bone of Ptyctodus indicates that the species was a durophage, though the sharpened anterior of a few individuals may have resulted in some shearing habits. They probably fed on hard-shelled invertebrates as do modern rays and skates with crushing dentition. Those with a sharpened anterior may have supplemented their diet with other fishes or soft-bodied invertebrates, either as predators or as scavengers.

The two specimens in the Buffalo museum were entombed in a very fine-grained, dark matrix most similar to the upper Moorehouse. This indicates that the fish preferred deeper waters or the water column that occurred over these deeper sediments. The Upper Moorehouse is known for its high diversity of brachiopods, potentially the dominant prey 
item for ptyctodonts. The specimen of Paraptyctodus had been excised from its matrix, so no paleoecological conclusions could be made. All three specimens came from the Cheektowaga Quarry.

\section{Palaeomylus}

Palaeomylus was described by Woodward in 1891, and, because it is so distinct, no synonymies have been reported. However, other forms may prove to be congeneric. Two species of Palaeomylus, P. crassus and P. frangens are known from the Eifelian of North America, but only P. frangens is found in the museum collections (Tables 5, 6). Denison (1978) notes that the species of Palaeomylus are poorly distinguished and need revision. Specimens in the Cleveland museum labeled as Rhynchodus frangens are actually Palaeomylus frangens.

Palaeomylus was also a durophage as indicated by a flat, broad dental surface. It was the largest of the ptyctodonts, its dental plates up to $15 \mathrm{~cm}$ in length. The dental plates are easily distinguished by the presence of three cusps and their deep, almost semicircular, appearance (Plate 4). Two of these tritors are visible in specimen E7765 (Plate 4A). A beak may or may not be present (Denison, 1978).

These plates are large, semicircular and resemble those of Rhynchodus. The plates of Palaeomylus are distinguished, however, by the presence of the small cusps near the center and the broad dorsal surface. More information on the non-dentary skeleton of both genera may prove that the two are part of the same genus, but belong to different species.

Palaeomylus was probably a bottom or near-bottom dweller that fed on benthic organisms since it was a durophage, and most ptyctodonts have been interpreted as living close to or on the bottom (Denison, 1978). Four of the seven Palaeomylus observed in the museum collections were from the Delaware Limestone. Three of the specimens were examined at the Field Museum of Natural History in Chicago, and another two were erroneously labeled as Rhynchodus secans, one of which was from the upper Columbus. The remaining two were from the upper Moorehouse. An eighth, from New York, was presumably misplaced because it could not be found at the Buffalo Museum of Science after the initial visit. Notes taken by the author on the specimen from the first visit state that the specimen was an indistinguishable plate, and the label indicated that the original collector was not sure if the plate was from Palaeomylus or from Dinichthys.

The Delaware and the upper Moorehouse are units marked by a rise in sea level, indicating that Palaeomylus may have been a predator of deeper offshore environments. The size of the dental plates and the lack of abrasion precludes the possibility that these plates were transported a great distance, such as from deeper waters.

\section{$\underline{\text { Rhynchodus }}$}

Rhynchodus was first described by Newberry in 1873 and synonyms include Ramphodus, Rhamphodus, Rhamphodontus, Rhychodontus, Rhychosteus, Rhynchognathus, and Ringinia (Denison, 1978; Tables 5, 6). Rhamphodopsis, often attributed to Rhynchodus plates, is a legitimate genus but of the Old Red Sandstone of Scotland (Denison, 1978). 
Rhynchodus is unique in that it is one of the few ptyctodonts to be represented by cranial and trunk plates as well as dental plates (Denison, 1978), although all of the specimens in the Buffalo and Cleveland museums are dental plates.

The dental plates of the upper jaw resemble those of Palaeomylus in that they are semicircular and may possess small cusps (Plate 5A-G). The upper dental plates of Rhynchodus, however, taper ventrally to form a shearing surface. The lower dental plates are not as deep, but possess the same shearing surface. The shearing margin of the upper plate is usually on the lingual (tongue) side while the margin of the lower plate is often on the labial (lip) side. The opposition of the two dental plates forms an ideal cutting organ. The dichotomy between the appearance of the two plates led to a great deal of confusion in the description of the genus due to misinterpretation (Denison, 1978).

None of the Buffalo Museum of Science specimens were originally assigned to a species. In the Cleveland Museum of Natural History collection, half were originally identified only to genus, though the other half belong to species not recognized by Denison (1978). These species include $R$. elegatus, $R$. longatus, $R$. minor, $R$. pygmaeus and $R$. tenius. None of the species names belong to any described ptyctodont except $R$. minor. Palaeomylus minor is found in the Frasnian of the Buffalo, New York, area and this may be the source of the misnomer. Only R. secans is valid within the Eifelian of the United States (Denison, 1978).

Specimen BW-3-106 (Plate 6A), Rhynchodus pygmaeus, possesses tubercles similar to Deinodus bennetti and may be a plate from that ptyctodont. Specimen BW-3-179 (Plate 6B), $R$. minor, is a partial plate that resembles the dental elements of "Conodus", described in this study as Deinodus ohioensis. Specimen BW-3-144 (Plate 6C), also R. minor, is probably an anterior lateral plate of some ptyctodont, though not necessarily Rhynchodus. Specimen BW-3-84 (Plate 6D), labeled as $R$. tenius, could be the lower dental plate of an unknown ptyctodont as it appears to possess a tritor. Specimen BW-3-195 (Plate 6E), labeled as $R$. longatus, may be a partial dental plate of Palaeomylus.

The Rhynchodus secans identified at the Cleveland Museum are from the Delaware, although many of the misidentified specimens are from the Columbus. Rhynchodus may have lived along side Palaeomylus since they both tend to come from the same units, though other taxa are also most common in these units. The two fish may belong to the same genus, but differences in jaw morphology and feeding habits prohibits the synonymy of species. The specimens of the Buffalo Museum are associated with the dark, laminated shales of the upper Moorehouse, which also suggests a deeper water habitat.

Specimen BW-3-155 (Plate 5A) illustrates the shape of the Rhynchodus lower dental very well. It uniqueness makes it seem hard to understand why so many Rhynchodus jaws ended up in the unidentified drawer at the Cleveland Museum. Specimens BW-3-418, BW3-504, BW-3-31, BW-3-364 and BW-3-466 (all Plate 5) are examples of Rhynchodus jaw plates that were never identified as such prior to this study. All were from the Delaware except for BW-3-418 and BW-3-504 which were from the upper Columbus

Specimen BW-3-210 (Plate 6F) was identified as a Rhynchodus clavicle. Ptyctodonts do not possess clavicles and BW-3-210 does not resemble an anterior lateral plate, the analogous bone in ptyctodonts. The specimen is, however, covered by tubercles reminiscent of Deinodus. The size of the specimen indicates that it could be part of the anterior ventrolateral plate, but the curved edge of the specimen is not seen on any of the anterior 
ventrolateral plates in the collections of either museum. The specimen most resembles a marginal plate, in which case, its size would indicate that the fish was very large.

\section{$\underline{\text { Deinodus }}$}

Deinodus bennetti was described in 1919 by Hussakof and Bryant, but its exact taxonomic affinity is unknown. Denison (1978) places the taxon in his "Placodermi incertae sedis" section and postulates that it may be an arthrodire, ptyctodont, or other placoderm. For the descriptions of the terms used in describing dimensions of plates, see Figure 19.

Determining the exact nature of Deinodus and its proper identification is very important to the understanding of the Onondaga units because the taxon overwhelms the Buffalo museum collection. Its prolific nature may be the result of a locally abundant population of an unknown fish or the misidentification of numerous fossils. The specimens of Deinodus are varied in shape, though most possess the characteristic large tubercles reported by Hussakof and Bryant (1918). Those specimens that do not possess tubercles resemble those that do possess tubercles. The great variety of fossils, however, can be reduced to a few basic shapes.

The first Deinodus morphotype is elongate, subrectangular to rounded and gradually tapers into a spine. Tubercles are usually only present on a margin, particularly near the widest point, though it is likely that those regions would have been less susceptible to abrasion and would have retained their tubercles, while elevated areas would have lost theirs. This structure can be quite long, exceeding 16 centimeters in length, yet only be a few centimeters in width. The length-to-width ratio of complete and partial plates always exceeds 3.0.

Specimen E18582 shows that the elongated plate is a spine (Plate 7A). E18582 is the anterior ventrolateral plate and the associated spine of Deinodus bennetti. Specimen E16648 (Plate 7D) is a disarticulated spine. Tubercles would have occurred on the outer margin of the spine. Both the anterior ventrolateral plate and the spine are thickest in the center giving the plates a dorsoventrally compressed appearance in cross-section. As the animal gets larger, the length-to-width ratio of the spine increases so that the largest spines are very long and narrow, and become more rounded in cross-section. Specimens E2466 and E2467 (Plate 7B-C) show cross-sections of a spine with the thick, elliptical character and a spine that has become more rounded, respectively. Specimen E16646 (Plate 7E-F) shows that the spine could have possessed small denticles, though they only appear in this specimen. These denticles may only appear later in life or may be susceptible to abrasion or disarticulation, hence their absence in other specimens. These denticles are not erosional products, and their occurrence has been documented in many other placoderms.

A second plate morphotype is shorter than the spine and rapidly tapers. This plate very closely resembles the dental plates of other Eifelian ptyctodonts. Like the spines, the tubercles are limited to the lower margin and the posterior, though the dorsal surface may also possess them.

There are two sizes of these structures. One specimen, E16639 (Plate 8A-B) is a well-preserved dental plate fragment that has been excised from its matrix. It clearly shows the presence of tubercles on the lower margin and the dorsal surface. The dorsal surface is flattened and tuberculated, making an ideal crushing surface. A prominent ridge parallels the lower margin just above the tubercles. The length-to width ratio of this specimen is $c a .2 .1$. 
A portion of the posterior is missing, but extrapolation suggests that the amount of missing bone is not significant. Specimen E16635 is a much smaller dental plate fragment, but with similar dimensions (Plate 8F).

Specimens E1860, E2471 and E18086 (Plate 8C-E) are all very similar structures. At first glance, they appear to be the posterior portions of spines. However, all three begin to round posteriorly at the same point and to the same degree. The length-to-width ratio is $c a$. 2.8-2.9 for all three. Tubercles are present on the lower margin, but not visible anywhere else and the lateral ridge is not prominent. The specimens are embedded within the matrix so that the dorsal surfaces are not visible.

Many ptyctodonts possess dimetric (of two different sizes) dental plates, the more robust being the upper plate. The two sizes of rounded plates may be the dental plates of Deinodus bennetti. The more robust plate could be the upper dental plate, and the tubercles present on the flattened dorsal side, now considered the ventor, could have served as crushing elements. The lateral ridge could have been a site of muscle attachment. The more elongate plate would have been the lower dental plate. It may have, or had, tubercles on the dorsal side, but any structure is hidden by the matrix. Ptyctodonts possessed a small gape, but had a powerful bite (Denison, 1978).

Alternatively, the dental plates of Deinodus may have elongated with growth. Of the plates from the Buffalo museum and those of a new species of Deinodus from the Cleveland collection, the one with the smallest length-to-width ratio, specimen E16635 (Plate 8F), is also the shortest in length. All of the elongated plates are at least one-third longer than the more robust plates, though only about one-eighth wider.

A third plate resembling the dental plates, E2461 (Plate 9E), appears in Hussakof and Bryant, (1918, plate 42, fig. 1) however, its length-to-width ratio, $c a$. 5.5, is well above the minimum value for spines ( $\mathrm{ca}$. 3.0). The bullet-like, tapering, posterior end is reminiscent of other spines. This specimen, however, was not observed in the Buffalo Museum, but a similar one, E2451 (Plate 9A), was observed. Both possess a side that was flattened and possessed tubercles. A groove near the anterior end may indicate that the element articulated in a way with the anterior ventrolateral plate that allowed some movement independent of the body. Other groups of placoderms, particularly the antiarchs, are thought to have possessed moveable pectoral spines. This specimen does not resemble the other spines, known to be the pectoral spines. However, it could be a dorsal spine, present in many other ptyctodonts (Long, 1997). If the spine could move, it may have provided stability or protection and was only raised when needed. Many modern fishes are capable of doing this (Wheeler, 1975).

A third plate morphotype is rounded and elongate, but with a slight curvature in the center and very little thickness. Its appearance is a combination of the dental plates and the spines, though it is much less common than either. It is similar to the marginal bones of Ctenurella (Janvier, 1998), but its size indicates that it may represent the anterior lateral plate of Deinodus. Specimen E16556 (Plate 9B) is a good example of this morphotype. It is much too long to be a dental plate and too curved to be a spine.

The fourth plate morphotype is nearly perfectly rectangular and is a portion of a spine. These plates possess the characteristic tubercles, but the tubercles are not limited to the lower margin or posterior. Specimens E16650 and E2465 (Plate 9C-D) represent the fourth morphotype. Specimen E2465 was interpreted by Hussakof and Bryant (1918) as a dental plate, possibly due to its similarity to the jaw of Ptyctodus, but it is now clear that it is a portion of a spine. Specimen E16651 (Plate 9F) illustrates how a fracture at a point of 
weakness could result in these plates.

Specimen E16646 (Plate 10) can be broken down into the first and fourth morphotypes. The first segment, E16655, is similar in appearance to the head of the spines. The central region is similar to the rectangular plates such as E16650 and E2465. The tip is very similar to the rounded spines of E2466 and E16644.

Tubercles are a common characteristic of the trunk shields of ptyctodonts (Long, 1997), but not necessarily of the dental plates. The anterior ventrolateral plate of Deinodus was observed in the collection in Buffalo and it, in no way, resembled the jaw elements. The anterior lateral plates of ptyctodonts are the largest bones in the body, and could not possibly be the tuberculated jaws of $D$. bennetti. It is likely that $D$. bennetti possessed tubercles over its entire dermal skeleton, including the jaws. Similar tubercles can be found on the cranial plates of BW-3-322 (Plate 12B), which indicates that tubercles were not limited to the trunk shield.

Very few of the other $D$. bennetti plates can be identified at the anatomical level. Specimen E16654 (Plate 11A) most closely resembles the marginal plates of other ptyctodonts, but its condition is too poor for a reliable identification. In addition, there are no visible tubercles present, making the identification as $D$. bennetti questionable. Specimen E16627 (Plate 11B) is a cranial plate of some kind, though it represents only a portion of the entire plate.

Asterosteus, reported from the Columbus, is another placoderm possessing tubercles, though its tubercles are very distinctly stellate. The tubercles of Deinodus are spherical crowns with striae extending from a raised base. The appearance is more similar to a sea urchin than to a sea star. However, if the elements of Deinodus are worn down, the result is a stellate appearance.

All of the Deinodus specimens at the Buffalo museum came from the Moorehouse, specifically, from the finer, upper areas where laminations and shaly beds occur. This indicates that Deinodus preferred deeper waters, but shallower than the Seneca. Because the dental plates are buried in matrix, it is impossible to know for sure if they were best suited for a crushing or shearing strategy, though most ptyctodonts were durophagous (Maisey, 1996) and Deinodus was probably a ptyctodont.

Two specimens in the Buffalo Museum, one of the genus Cosmodus, the other of the genus Casnodus, were associated with the species name, "bennetti". These specimens are mislabeled Deinodus bennetti spines. Both have been excised from their matrixes.

Five specimens in the Cleveland Museum labeled "Conodus" are almost identical in appearance to the dental plates of Deinodus bennetti (Plate 13). However, the large, obvious tubercles of $D$. bennetti are absent in the "Conodus" specimens and the "Conodus" specimens are much smaller. The length-to-width ratio in four of the five specimens (BW-3117, BW-3-150, BW-3-185 and BW-3-405) is ca. 2.1-2.2, very similar to that of the upper dental plate of Deinodus bennetti. The fifth specimen, BW-3-168, has a length-to-width ratio of $c a$. 2.4, though part of the lower margin appears to be missing.

The prominent ridge on the dental plate of Deinodus bennetti is present in all five of the "Conodus" specimens. The ridge runs along the lower two-thirds of the plate, as it does in $D$. bennetti, though a thickened section may be found about three-quarters of the way to the anterior tip. The diameter of this protuberance is about two-thirds the width of the jaw at the point where the center of the protuberance occurs.

Tubercles are not present on any of the "Conodus" specimens. Small bumps on the 
surface appear to be linked to the vascular canals beneath, but are only visible when magnified under a dissecting scope. These bumps may have aided in sensory reception or may have been the sites for skin or muscle attachment. A second, larger type of bump occurred occasionally and randomly, but may have been the result of the differential erosion of the outer covering. These larger bumps are not nearly as large or numerous as the tubercles of $D$. bennetti, nor do they possess the striated crown of the D. bennetti tubercles.

Specimen BW-3-117 (Plate 13B, F) is formed by two elements. The anterior portion looks identical to the other four specimens thought to be dental elements. Length and width measurements, taken on that portion were found to be consistent with the other four.

The second portion is a very thin, dark, nondescript, partial extension of the anterior piece. Its thin nature would make it seem impossible to support the pressures associated with crushing. However, this posterior addition may be ossified cartilage. Other ptyctodonts possessed ossified cartilage to hinge and anchor the dental battery (Long, 1997).

It seems unlikely that the "Conodus" elements are anything other than dental elements since they so closely resemble other known dental plates, and dental elements dominate the collections of both museums. They do not look like spines or other non-dentary plates and closely resemble the dental elements of $D$. bennetti. Regardless of their interpretation, they are distinct elements of the Columbus Limestone, and they are very similar to fossils of $D$. bennetti. For these reasons, I consider them to be a distinct species and have chosen to place them within the genus "Deinodus" (see formal description below).

All of the "Conodus" specimens were collected in the upper Columbus. This indicates that they may have preferred slightly shallower waters than their piscine peers. The new species may have been smaller that Deinodus bennetti and preferred shallower water. Alternatively, the Ohio fish may be juvenile Deinodus bennetti and the upper Columbus Sea was their nursery area. Tubercles may be an ontogenetic feature. However, the specimens represent distinct elements and the absence of tubercles may warrant the creation of a new form species in the Eifelian of Ohio.

The similarity of the spurious genera Conodus, Cosmodus, and Casnodus may be the result of perpetuating an erroneous genus. The "Conodus" specimens were probably compared to the Buffalo collection containing Cosmodus and Casnodus and referred to as "bennetti" because of their similarities. For some reason, Deinodus was not applied to the fossils even though it was the only genus that had been formalized. The genus was incorrectly written as "Conodus" rather than "Cosmodus" or "Casnodus". A previous worker apparently also noticed the similarities between "Conodus" of the Columbus and Deinodus bennetti of the Onondaga.

The genus "Conodus" is invalid because it has already been applied to a Jurassic amiiform fish, so I have elected to place the specimens within the genus Deinodus as a new species. A spine of Deinodus bennetti, specimen BW-3-468b (Plate 22D), was found in the Columbus Limestone, showing that it also existed there. The specimen is not a shark spine. It is more rounded and its ornamentation is not superficial, as in shark spines (Zangerl, 1981), but is part of the internal structure of the spine. It is almost identical to E2451 and E2461 (Plate 9A, 9E), possibly dorsal spines.

Specimen BW-3-322 may be very important in understanding the taxonomy of the Columbus fishes (Plate 12). It was labeled "Onychodus", but is most certainly the cranial bones of a very small, possibly juvenile, ptyctodont. Plates such as the preorbital, central, nuchal, and postorbital are visible and fully articulated in this specimen. The plates are 
heavily tuberculated and the tubercles are stellate on the anterior tips of the cranium. Stellate tubercles are a character of Asterosteus, but have not been reported in Deinodus. The cranium, however, is not that of Asterosteus, indicating that stellate tubercles may be the result of erosion in Deinodus. It also shows that Deinodus tubercles were not limited to the trunk shield and raises doubt on the occurrence of Asterosteus in the collection of the Cleveland Museum.

Specimens of two other invalid genera may be very similar to the Ohio Deinodus. Specimens of Delphinodus are very similar, but the anterior portions of the dental elements form an upturned point. Specimens BW-3-191, BW-3-151 and BW-3-187 (Plate 11C-E) show the structure well. Specimens of Pulsodus, such as BW-3-107 and BW-3-183 (Plate 11F-G), may also be Deinodus, or a similar ptyctodont. Further research is needed to fully understand these specimens.

The specimens of Deinodus bennetti in the Buffalo museum are most similar to other ptyctodonts, from the same units and from Australia. The long, rounded pectoral spine, however, is more reminiscent of Lunaspis, a petalichthyid from Australia (Long, 1995). Because Lunaspis was not as compressed as other petalichthyids, particularly Macropetalichthys, it superficially resembled a ptyctodont. Lunaspis could have been a ptyctodont-like petalichthyid with a rounded skull, and Deinodus could have been a petalichthyid-like ptyctodont with a long, rounded spine. Considering the close relationship of the two families (Figure 18), Lunaspis and Deinodus could have been transitional forms between the petalichthyids and ptyctodonts.

\section{$\underline{\text { Eczematolepis }}$}

Eczematolepis was first described by Miller in 1892. Its synonyms include Acantholepis and Phlyctaenacanthus (Tables 5, 6). Eczematolepis itself, however, may actually be a synonym of Palaeomylus (Denison, 1978).

In the Eifelian of North America, Eczematolepis is represented by the species, $E$. fragilis. Synonyms for the species include Oracanthus granulatus and O. abbreviatus (Denison, 1978) (Tables 5, 6). In addition, numerous specimens labeled "Acantholepis" can be found in the Cleveland Museum, and are probably Eczematolepis plates. The genus is reported from the Onondaga, though no specimens were found at the Buffalo Museum. The species ranges into the Frasnian, and its plates may be up to $20 \mathrm{~cm}$ in length.

Eczematolepis is a good example of the little knowledge available about North American, Eifelian ptyctodonts. It is a genus known only from isolated plates that "may be broad and thin, or thicker, pointed and spine-like" (Denison, 1978; Page 30). This may be an indication that the genus is a 'garbage can' where various plates are placed in a genus when proper identification is not possible. The fact that Eczematolepis fragilis is the only Eifelian ptyctodont species that ranges into the Givetian is further evidence that the genus may be composed of numerous unrelated taxa.

Eczematolepis and Palaeomylus are the only two placoderms that possess acellular bone. Some of the confusion surrounding the identification of this genus could be cleared up if histological analyses could be conducted on the specimens of the Cleveland and Buffalo museums. It has often been speculated that the plates attributed to the Eczematolepis actually belong to Palaeomylus, a genus only known from dental plates. Indeed, the two forms are often found in association. Denison (1978), however, cautions a permanent placement of 
Eczematolepis among the ptyctodonts until better material is found. It should be noted that the French fish paleontologist, Daniel Goujet, has performed histological analyses on Eczematolepis and does not believe that the genus should be placed within the placoderms (Carr, personal communication).

Eczematolepis is represented by broad, spine-like dermal plates with tubercles that are irregularly or concentrically arranged. The tubercles of Eczematolepis are similar to those of Macropetalichthys, but the plates do not exactly match those of the petalichthyid. Plate 14 shows several specimens labeled as Eczematolepis and a specimen of Macropetalichthys for comparison. All four of the Eczematolepis plates are interpreted as submarginals and all illustrate the organized nature of the tubercles, similar to the ornamented anterior ventrolateral plate of Macropetalichthys (Plate 14A). Palaeomylus may not have possessed tubercles on its dental plates, but the cranial and postcranial bones could have. It is a genus known only from dental plates, so the plates of Eczematolepis could represent the rest of the skeleton.

Most of the distinct specimens of Eczematolepis in the Cleveland Museum of Natural History are from the Delaware, some from the finer-grained upper units. Many less reliable identifications of Eczematolepis are from the Columbus. Like Palaeomylus, Eczematolepis was most common in deeper, open waters, but was also found in the shallower units below. Because of its questionable systematics, however, it should be regarded only as a form genus for the moment. The genus is reported from the Onondaga (Denison, 1978), but those specimens were not well preserved and their placement as Eczematolepis is dubious.

\section{$\underline{\text { Asterosteus }}$}

Asterosteus is a genus of rhenanid that was first described by Newberry in 1875 . The rhenanids are dorsoventrally compressed placoderms with large, tuberculated plates. The flattened body and the heavy armament limited these fishes to a benthic life habit (Denison, 1978). Fossils of this taxon were reported from both the Delaware and the Columbus Limestones.

The presence of numerous stellate tubercles was a very distinct character used to identify Asterosteus. However, ptyctodonts, particularly Deinodus bennetti, have been shown to possess stellate tubercles. The type specimen is a cranium, composed mostly of small elements called tessarae (Denison, 1978), but all of the specimens in the Cleveland Museum are disarticulated plates. BW-3-194 (Plate 15A) and BW-3-113 (Plate 15B) are anterior lateral plates of Deinodus, and BW-3-376 (Plate 15E) is a spine of Macropetalichthys, all plates unknown in Asterosteus.

When compared to BW-3-322 (Plate 12), it becomes obvious that BW-3-417 and BW-3-103 (Plate 15C-D), labeled as Asterosteus are parts of a ptyctodont cranium. Because stellate tubercles were found on specimen BW-3-322, specimens possessing a stellate ornament should not be identified as Asterosteus without further analysis. Specimen BW-3322 is distinctly a ptyctodont, so a stellate tuberculation among Eifelian placoderms in the Columbus Sea is not limited to Asterosteus. Asterosteus was present in the Columbus Sea, but is absent in the collections of the Cleveland Museum.

Specimen BW-3-113 (Plate 15B) possesses the stellate tubercles similar to the tubercles found on Deinodus. The stellate appearance may be the result of a superficial layer of bone that, when eroded away, reveals the crown structure below (Plate 15F). The stellate 
tubercles on specimen BW-3-113 are limited to the most elevated region of the bone, the area most susceptible to abrasion. On specimen BW-3-322, the stellate tubercles are on the margin, also more susceptible to erosion than other areas. Areas where tubercles are stellate are lighter in color, possibly because a superficial, darker layer has been removed. Stellate tubercles only occur in these lighter regions.

Acanthodians

Acanthodians were the first jawed fishes to evolve (Denison, 1979), but they remain one of the more enigmatic groups. Nelson (1994) considers them teleosts and a sister group of the actinopterygians and sarcopterygians. All of the acanthodian specimens labeled in the two museums were spines of Machaeracanthus. It was first described by Newberry (1857) and synonyms include Machaerius and Dinacanthodes (Denison, 1979; Tables 5, 6).

The spines of Machaeracanthus are long, slightly curved and laterally compressed (Plate 16A-B). A ridge runs down each face and the anterior edge is sharp (Denison, 1979). Unfortunately, spines are a universal character of the acanthodians and do not reveal much about the ecology of the organism to which they belonged. Other, better known acanthodians are active swimmers that were either filter-feeders or predators (Long, 1995). A Machaeracanthus tooth from Europe may indicate the genus was a predator (Denison, 1979), possibly a piscivore.

Two species, both described by Newberry in 1857, are found in the Buffalo Museum of Science and the Cleveland Museum of Natural History collections. Machaeracanthus major and M. peracutus are found in both collections. A third species, M. sulcatus is reported from the Columbus Limestone, but was not found in the collections.

Newberry (1873) reports Machaeracanthus spines over 20 inches $(51 \mathrm{~cm})$ in length, but none of the museum specimens reached lengths, or implied lengths, of greater than about 10 inches $(24 \mathrm{~cm})$. Newberry's report of the two species places their lengths within morphometric categories that could easily be attributed to ontogenetic growth. Machaeracanthus major spines are 12-20 inches $(31-51 \mathrm{~cm})$ in length and M. peracutus, 5-6 inches $(13-15 \mathrm{~cm})$. As the fish grew, the spine's edge would become less sharp. The angularity of the ventral and dorsal ridges is identical in both taxa.

Because of a lack of distinction between the two taxa, $M$. major should be considered a synonym of $M$. peracutus. Denison (1979) retains the separate species, but devotes little discussion to the genus, considered as incertae sedis. Machaeracanthus major is the adult form of $M$. peracutus.

Three specimens in the Cleveland museum may represent body parts. Specimen BW3-414 (Plate 16C) was labeled as "cf. Onychodus". However, it more closely resembles the scapula of an acanthodian. BW-3-149 (Plate 16E) is the jaw of an acanthodian and BW-3-95 (Plate 17D) is a portion of an acanthodian tooth whorl. Since Machaeracanthus is the only acanthodian attributed to the Columbus, these specimens should be reassigned to the genus. It seems unlikely that there was only one genus of acanthodian present in the Eifelian seas of North America, but until more and better specimens are described, Machaeracanthus should be assigned to acanthodian material collected from units of the North American Eifelian. The single tooth from Europe may indicate that Machaeracanthus is a member of the Ischnacanthidae, the most predatory of the acanthodians (Denison, 1979). The occurrences of the tooth whorl and the toothed jaw from the Columbus supports that assertion. 
In Ohio, Machaeracanthus is found in the Columbus and Delaware. A spine found in the Delaware of Sandusky is the only fish fragment collected by the author during this study. In the Onondaga, specimens were from the lower and upper Moorehouse and the Seneca. The presence of Machaeracanthus in rocks formed in deeper waters implies that they were pelagic predators. There was no relationship between water depth and spine size.

Onychodontiformes

Onychodus and Strunius are the only taxa within the Onychodontiformes, an order placed within the sarcopterygians (Nelson, 1994), though it may be polyphyletic (Maisey, 1996). They share a number of characteristics with both the crossopterygians and the actinopterygians (Long, 1995; 2001), and may have been transitional between the two groups. Specimens of Onychodus collected in the Eifelian of North America include disarticulated cranial bones and teeth, though more complete specimens have been found in Australia. The genus was described by Newberry in 1857.

The most distinguishing characteristic of Onychodus is the large tooth whorls of the lower jaws (Plates 17, 19). The lower jaw articulated with the upper jaw in a way that when the head was raised, the tooth whorl acted as a dagger, impaling passing prey (Long, 1995). The nearly $2 \mathrm{~m}$ long fish may have lived like a modern eel and snagged fish as they swam by (Long, 1995). The dorsal fins of the Australian form were placed near the tail and the humerus supported large muscles and robust pectoral fins (Long, 1995). These characteristics are best suited to shallow-water ambush predators.

Very few of the bones assigned to Onychodus in the Cleveland Museum of Natural History can be identified. Long (2001) illustrates a fully articulated Onychodus from Australia (Plate 18), but few of the bones of museum specimens can be definitively correlated to those of the Australian form.

Specimens BW-3-410 (Plate 17B) and BW-3-362 (Plate 17C) appear to be the parietal (central cranial) bones, but on opposite sides of the cranium. Specimen BW-3-276 (Plate 18A), and to a lesser degree, specimen BW-3-252 (Plate 18B), resembles an elongate opercle (gill cover) bone. Specimen BW-3-184 (Plate 18C) appears to be a portion of an opercular bone. Specimens BW-3-325 (Plate 18D) and BW-3-368 (Plate 18E) would most likely belong to the shoulder girdle. BW-3-361 (Plate 18F) is a very similar structure.

The subopercles (gill cover) of Onychodus do not look like anything else in the collections. They are rounded with oscillating edges and concentric rings. Specimen BW-3372 (Plate 19A) illustrates the appearance of a small, possibly juvenile onychodontiform fish subopercle.

Unidentified specimens BW-3-452 (Plate 19B) and BW-3-462 (Plate 19C) are very similar to the bones labeled as Onychodus, but cannot be identified. BW-3-498 (Plate 19D) is labeled as Onychodus, but definitely belonged to a ptyctodont.

To fully ascertain the nature of the North American Onychodus, a fully or partially articulated specimen needs to be found. The beautifully preserved Australian specimen gives us an idea of what the North American form may have looked like, but is so different that nothing definitive can be written at this time.

Specimen BW-3-322 (Plate 12B) is labeled as Onychodus, but is a compressed skull of a ptyctodont. The large tubercles are not observed in other Onychodus specimens, but are characteristic of Deinodus, a ptyctodont. In addition, it was collected from the Onondaga 
where Deinodus is prevalent and Onychodus is not common.

Onychodus was present in the Buffalo Museum of Science collection, though in numbers far less than in the Cleveland collection. The specimens of Onychodus from the Buffalo Museum were from the upper Moorehouse and nearly always associated with shaly layers. In the Cleveland Museum, the distinct specimens were nearly always from the Delaware Limestone and very often associated with Tentaculites.

Evidence indicates that the Onychodus of Australia was an ambush predator associated with structural relief (Long, 1995). Strong pectoral fins are good for "crawling" around in shallow water or between coral colonies. Posteriorly placed dorsal fins provide quick and powerful bursts of speed for capturing prey. However, the North American Onychodus was found in units notoriously low in coral diversity and abundance.

Onychodus was common in the deepening facies of the Delaware, but less common in the upper Moorehouse, a facies that may have been similar in depth to the Delaware. The waters of the Onondaga may have been less than ideal for Onychodus, at least as far as habitat or prey availability are concerned. Onychodus may not have been collected from the deeper, upper units of the Seneca because the taxon was never common in New York and few units of the upper Seneca have ever been sampled due to their scarcity.

The Tentaculites of the Delaware possessed heavy, fortified conchs, indicating that they were probably benthic forms (Bergstrom, 1996). The notable presence of these enigmatic forms with the Onychodus of the Delaware, and their scarcity in the Onondaga, may indicate that they preferred the same habitat as the large fish, apparently, deeper, open waters.

Improperly identified or unidentified specimens

There are several specimens in the Cleveland Museum of Natural History labeled as invalid genera. These genera include Bilobodus, Asperichthys, Tanaodus, Delphinodus, Platoditus, Platygnathus, Pulsodus, Gyrtacanthus, Secansodus and Dentichthys. Some of the genera are valid; for example, Platygnathus is a Jurassic crocodile, but none are associated with Eifelian fish in North America. Some of the others are probably misspelled valid genera. Most of the incorrect genera are associated with one, or only a few specimens.

$\underline{\text { Valid Genera assigned to incorrect specimens }}$

Six specimens identified as the antiarch Asterolepis, and three more tentatively assigned to the genus, were found in the Cleveland Museum. However, Denison (1978) does not report the genus, or even the order Antiarchi, from anywhere in the Eifelian of North America. It is impossible to identify most of the plates to form or function. Those plates that can be identified probably belong to Eczematolepis. Many with tubercles were probably thought to be Asterosteus. The misnomers may have resulted from the similar spellings of the genera, Astrolepis (Eczematolepis), Asterolepis and Asterosteus.

Plates of the arthrodires, Coccosteus and Dinichthys are found in both museums, and both genera have been reported from the Eifelian of North America. However, these specimens are in very poor condition or are indistinguishable and should not be designated to those genera. No good arthrodire plates were found in the Eifelian collection at either museum. Considering the rarity of arthrodires in the Eifelian of North America, it is more 
likely that the specimens are the distal portions of Rhynchodus or large Ptyctodus dental plates and the cranial plates of an unknown ptyctodont.

A small portion of a spine labeled as "Gyracanthus" in the Buffalo Museum is actually the basal portion of a Machaeracanthus spine. A specimen of Cyrthacanthus in the Buffalo Museum appears to be the clasper of some species of ptyctodont. A tooth plate of Chirodipterus in the Cleveland Museum, labeled as having been found in the Columbus, was embedded in the same Catskill Delta matrix that encrusted other specimens of the dipnoan.

Dinomylostoma, a genus assigned to a specimen in the Buffalo collection, does not occur in the Eifelian of North America (Denison, 1978). This plate is a well-worn dental plate of Ptyctodus. A specimen labeled as "Cladodus" from the Cleveland Museum of Natural History is likewise misidentified. Cladodus are known only from the Upper Devonian and Lower Carboniferous of Germany as neurocrania or as teeth representing polyphyletic taxa. The "Cladodus" specimen found in the Cleveland collection is a poorly preserved, unidentifiable placoderm plate.

\section{$\underline{\text { Unknown genera }}$}

Asperichthys may be the result of a typographical error. The genus Asterichthys has been associated with a Lower Devonian arthrodire, but the taxon is a nomen nudum (Denison, 1978). Aspidichthys is a large arthrodire of the Upper Devonian. Specimen BW3-199 (Plate 20E) is labeled Asperichthys on the matrix, but the associated card correctly indicates that it is a plate of Acantholepis (Eczematolepis). None of the other specimens are identifiable, though BW-3-171 is a spine of some kind (Plate 20A).

Specimens of Tanaodus and Stenoichthys are spines of an unknown ptyctodont. Specimen BW-3-361 (Plate 20B), suspected to be Stenoichthys by the collector, is probably part of the pectoral girdle of Onychodus as it resembles the cleithrum of teleost fishes. As mentioned above, specimens BW-3-107 (Plate 20D) and BW-3-183 (Plate 20H), identified as Pulsodus, may be the dental plate and spine, respectively, of Deinodus ohioensis.

Cavagnathus specimen BW-3-232 (Plate 20F) represents the anterior lateral plate of a ptyctodont. Specimen BW-3-206 (Plate 20G), identified as Coultraotus delicatus, is a Ptyctodus dentary plate. None of the other specimens of these genera were identifiable.

Nearly all of the specimens labeled as Secansodus are spines of unknown ptyctodonts. Spines are more robust than most other plates, and, therefore, are more likely to be preserved. Specimen BW-3-111 (Plate 20C) is a good example. However, specimen BW-3-342 is a jaw of Rhynchodus and BW-3-328 and BW-3-96 are Ptyctodus dental plates (Plate 20I-K).

\section{$\underline{\text { Unidentified specimens }}$}

Many of the unknown, unidentified specimens at the Cleveland Museum of Natural History are recognizable in function, but not taxon. There are several anterior lateral plates and spines, but the taxa from which they came are unknown. Others, however, can be assigned to genera.

Specimens BW-3-474 and BW-3-31 (Plate 21A-B) are dental plates of Rhynchodus. Specimens BW-3-366 and BW-3-360c (Plate 21C-D) are portions of Machaeracanthus spines. Specimen BW-3-376 (Plate 15E) is a spine of Macropetalichthys. Specimens BW-3- 
390 and BW-3-454 are the anterior ventrolaterals and spines of Macropetalichthys (Plate 21G-H). Specimen BW-3-11471 (Plate 21F; reconstruction 21E) is labeled as a Rhynchodus jaw, but is actually the submarginal plate of a ptyctodont.

Specimen BW-3-456 (Plate 21I) resembles the anterior ventrolateral plate and spine of Macropetalichthys, though the spine is much more elongate. Specimen BW-3-412 (Plate $21 \mathrm{~J}$ ) also resembles the anterior ventrolateral plate and spine of Macropetalichthys, but the articulation of the spine with the anterior ventrolateral plate is much more acute. These specimens do not appear to have been deformed by postmortem processes. They may represent portions of the ventral skeleton of one of the ptyctodonts in the collection known only by dental plates, though they bear little resemblance to the anterior ventrolateral plate and spine of Deinodus bennetti, a ptyctodont.

Specimens BW-3-468a, BW-3-447 and BW-3-240 (Plate 22A-C) are poorly preserved anterior ventrolateral, spine and dental plates, respectively, but they appear very similar to Deinodus bennetti. What appear to be D. bennetti-like tubercles may be present on all three. Specimen BW-3-468b proves that $D$. bennetti occupied the waters of Ohio. It is a spine with well-preserved tubercles (Plate 22D).

Specimens BW-3-377, BW-3-345, BW-3-453, BW-3-355, BW-3-451 and, possibly, BW-3-360 (Plate 23A-F), are plates with a round, flattened posterior end that tapers into a curved, robust, elongated anterior end. These are probably the marginal bones of some ptyctodont.

The unidentified specimens of the Buffalo Museum of Science are fewer and less recognizable. This may reflect the presence of more experienced workers in the Buffalo Museum than at Baldwin-Wallace College, the source of much of the Cleveland collection and the origin of the ' $\mathrm{BW}$ ' portion of the specimen numbers.

Specimen E18094 (Plate 24A) is very similar to plates of Deinodus bennetti and to the robust plates that may represent anterior lateral plates. Both ends of this specimen are rounded, an unlikely arrangement for a marginal plate, so it is more likely an anterior lateral plate, albeit that of a juvenile.

Specimens E22102 and E18115 (Plate 24B-C) are portions of Macropetalichthys spines. Specimen E18440 (Plate 24D) is a tooth of Onychodus, E17940 (Plate 24E) is the dental plate of a very small Ptyctodus and E18223 (Plate 24F) is the jaw of Palaeomylus. Specimen E22106 (Plate 24G) is an unknown plate, but it shows the sculpted pattern of Macropetalichthys.

Specimens E18106, E18112, E18087, E18095 and E18102 (Plate 25A-E) are all plates belonging to Deinodus bennetti. Specimen E18106 is a spine, E18112 is an anterior ventrolateral plate and E18087 is a dental plate. Specimens E18095 and E18102 are unknown plates, but both exhibit the characteristic tubercles of Deinodus bennetti. Specimen E18389 (Plate 25F) is probably an interohyal of a ptyctodont, likely $D$. bennetti, as it was collected from the same horizon in the same quarry.

Formal Description

Deinodus ohioensis n. sp.

\author{
SYSTEMATIC PALEONTOLOGY \\ Class PLACODERMI M'Coy, 1848 \\ Order PTYCTODONTIDA Gross, 1932
}


Family PTYCTODONTIDAE Woodward, 1891

Genus DEINODUS Hussakof and Bryant, 1919

DEINODUS OHIOENSIS n. sp.

Plate $13 \mathrm{~A}-\mathrm{F}$

Diagnosis- Small plates rounded posteriorly and tapering to a tip anteriorly, unornamented, with a ridge running from the median of the tip to the lower $1 / 3$ of the posterior, thickest about 3/4 the distance from the posterior to the tip; tubercles are absent and there is no beak-like projection at the distal tip.

Description- Length $46.3 \mathrm{~mm}$, maximum width $20.8 \mathrm{~mm} 32.3 \mathrm{~mm}$ from the tip; length-to-width ratio 2.2; gradually tapers from maximum depth to tip and to posterior; tip nearly comes to a point, posterior more rounded and depth much greater; dorsal surface level with no evidence of structure.

Holotype- Specimen 50208 (old number BW-3-150; Figure 15A) is deposited at the Cleveland Museum of Natural History (CMNH), Cleveland, Ohio.

Paratypes- Specimens 50207, 50209, 50210 and 50211 (old numbers BW-3-168, BW-3-117, BW-3-185 and BW-3-405, respectively; Figure 15 A-F) are similar in size and length-to-width ratio and are also housed in the CMNH.

Etymology- The name, ohioensis, differentiates this form, found in Ohio units, from the form $D$. bennetti, found in units of New York.

Geographic and stratigraphic position- The holotype of Deinodus ohioensis was originally collected in the area in or around Lakeside, Ohio. Its exact stratigraphic position is unknown, but the surrounding matrix is most similar to the Delhi Member (also known as the Marblehead Member, in part) or the upper Columbus, particularly, the upper most units.

This unit is described as gray to tan, coarse, nearly pure limestone that is very fossiliferous. It is about 20 meters thick and was deposited as a subtidal bank just below wave base in a regressing sea. It is bound below by the Bellepoint Member and above by the Venice Member or the Delaware Limestone (Stauffer, 1957; Sparling, 1988). The rocks characteristic of the matrix are best developed about six meters below the contact of the Columbus and Delaware Limestones in northern Ohio and about eight meters above the contact of the lower and upper Columbus in central Ohio. In this part of the member, water depth at the time of deposition was very shallow. The rocks of the Columbus are very homogenized and the delineation of members can vary at different locations. Therefore, the exact placement of this unit can only be accomplished in the field, and no paleoecological interpretations can be made.

Remarks- Denison (1978) is not confident in placing Deinodus in the order Ptyctodontidae. He places the genus as "incertae sedis" stating, "These could belong to an arthrodire, ptyctodont or possibly to some other placoderm." However, the anterior ventrolateral plate and adjacent spine of specimen E18582 (Plate 7A) in the Buffalo Museum and the cranium of BW-3-322 (Plate 12) from the Cleveland Museum are distinctly ptyctodont. The only other placoderm in which they could belong would be a petalichthyid, and they are clearly not those of Macropetalichthys.

From these anterior ventrolateral plates, a comparison was made with other $D$. bennetti specimens, all possessing diagnostic tubercles. The dental elements easily identified once the specimens representing spines and cranial plates were identified. Denison (1978) 
was probably confusing dental plates and spines as he indicated that the Deinodus fossils were all dental elements. Apparently, he never examined specimen E18582.

Deinodus ohioensis bears a striking resemblance to the dental plates of $D$. bennetti, though there are no tubercles. Deinodus ohioensis is much smaller, though the length-towidth ratio is the same as in the more robust dental plates of $D$. bennetti, and the lateral prominence running the length of the element is similar. The dental plates may become more elongate with age.

The specimens of Deinodus in Ohio are not Deinodus bennetti since they do not possess the characteristic tubercles. Specimen 50212 (old number BW-3-468b) is distinctly a $D$. bennetti spine and possesses well-preserved tubercles. It was found in the same horizon as $D$. ohioensis, eliminating the possibility that $D$. ohioensis is an ecotype that did not possess tubercles. The Ohio specimens are rather well-preserved, and there is no evidence that tubercles were present on the D. ohioensis specimens, but were worn away.

\section{DISCUSSION}

Columbus and Delaware Limestones

The depositional history of the Columbus and Delaware Limestones is very similar to that of the Jeffersonville and North Vernon Limestones in Indiana (Leonard, 1996). In Ohio, the Eifelian began in deep water where energy levels were low. During this time, the lower Columbus was deposited. The Lower Columbus is fine-grained and nonfossiliferous, but is characterized by the presence of very small crinoids and a coral bed near the top. Several authors have reported this bed (Stauffer, 1957; Sparling, 1988), some using it to mark member boundaries (Schuchert, 1943). This bed marks a topographic high in an otherwise deeper sea. Other smaller coral beds are present in the unit, but the one near the top persisted for some time. It is possible that this bed is younger in northern units since it is used to mark contacts in that region, but not further south where it is contained within the lower Columbus. The small crinoids may represent a stunted fauna.

Above the coral bed in Indiana, Leonard (1996) reports a lagoonal setting with gastropods and rugose corals and bound above by a major flooding surface (Figure 16). Above this rests shallow, open-water units. In Ohio, the unit above the coral bed is similar to the unit below, but with more fossils and larger grains. It represents a relative rise in sea level though not one as extreme as the one that occurred in the unit below the coral bed. It is certainly not lagoonal. Above this rests a coarse fossiliferous unit characterized by gastropods and rugose corals.

In Ohio, there is a distinct shallowing trend through the Columbus. The lower units of the upper Columbus contain gastropods and rugose corals, but brachiopods were either not well suited for the deeper waters, or, more likely, were displaced by the other organisms.

The waters were agitated so that rugose corals could survive. Upsection, however, this unit grades into a unit with very few rugose corals and no gastropods, but numerous brachiopods. In the upper units, the substrate may have been inhospitable to corals.

In Indiana, the lagoonal unit represents an area sheltered by a barrier, probably the boundstone, but not necessarily a lagoon. The reef rock would have prevented agitated waters from reaching the back reef, creating an environment where energy is low and mud is 
common. Above this sheltered facies, shallow water conditions prevail and there is a gradation from rugose corals in the lower units to brachiopods near the tops.

The lower unit and the "lagoonal" unit are the same biofacies as the upper units of the lower Columbus and the lower units of the upper Columbus. Sparling (1988) thought that the Marblehead Member, probably correlative with the upper unit of the lower Columbus, was lagoonal, but there was nothing in the units observed in Ostrander, Ohio, to indicate that the section was any different than the unit below the coral, a deeper water deposit.

In Ohio, a flooding surface would have occurred at the top of the coral bed because deep water units rest above the biostrome. The same surface occurs in Indiana atop the barrier unit. Above these rocks, the brachiopod-dominated facies are nearly identical. In both places, the units below the brachiopod facies were dominated by rugose corals, but rugose corals are rare in the unit above the brachiopod facies.

Above the brachiopod-dominated unit, Leonard (1996) reports another major flooding surface and deposition of the North Vernon Limestone, a unit marked by one, possibly two, flooding events. This unit is nearly identical to the Delaware Limestone. However, in Ohio, above the brachiopod-dominated unit, there is a very coarse skeletal hash layer. This represents a shallow-water sand bar or shoal, the top of which is marked by tidalites and scour surfaces, indicating that the waters were shallower in Ohio prior to the Delaware/North Vernon transgression. The units in Indiana were subaerially exposed prior to the transgression.

The Delaware and North Vernon seas were contemporaries (Shaver, 1985), especially if the Tioga Bentonite is reliably interpreted in Indiana. The boundary of the Columbus and Delaware Limestones is marked by the only bone bed that can be traced across the state (Wells, 1947). The bone bed is a transgressive lag, the result of the same flooding that began the deposition of the North Vernon Limestone.

The Delaware Limestone has long been thought to be a shallow-water deposit based on crinoidal sands and bone beds. Wells (1947) was among the first to promote this idea. He reported that the first few centimeters of the Delaware were marked by fish remains, pieces of the Columbus Limestone, and small particles of heavy minerals. He made a point of noting the lack of carbonate material and any sedimentary structure. Above the bone bed, the unit was characterized by small crinoid columnals. He also noticed that within the member, rugose corals were rounded while brachiopods, bryozoans, and fish were in very good shape.

However, it now seems clear that the Delaware was formed by a series of deepening events. Fish remains comprised the majority of fossil material that was deposited in the times following floods because the waters were too deep for calcareous organisms to flourish. The only material available would have been the bones of fishes that lived in the water column and the bones of prey items contained in the feces of predatory fishes.

The accessory minerals were of a size, as Wells (1947) noted, to have been brought in by winds. The limestone fragments of the upper Columbus were rip-up clasts that were incorporated into the Delaware by the flooding event. Above the fish bed, small crinoids indicate shallower waters, and they may represent the same stunted fauna that are found in the deep-water units of the lower Columbus. These tiny crinoids may be deeper water species since they only appear in deeper units, and they would have been the first to colonize the new habitat. The shallowing trend continues in the rocks above where brachiopods and bryozoans occur. 
Rounded corals were ripped from the carbonate units below, were worn during the events, and incorporated into the transgressive rocks. The fact that delicate bryozoans and fish were not harmed indicates that they lived in the benthic or pelagic facies of the Delaware in which they occur and were not exposed to additional abrasion. The waters were probably too deep or too cold for corals to exist.

Wells (1947) also acknowledges the fact that there are no ripple marks or crossbeds to support his claim of a shallow water environment. These features, along with tidalites, were observed at the top of the Columbus.

As mentioned earlier, Westgate and Fischer (1933) also chose to ignore evidence of a deep-water origin. They reported many observations that are indicative of deeper waters, including high concentrations of mud, faunas dominated by a few taxa, pyrite, and shaly partings, in addition to the bone beds that were devoid of anything but phosphatic material and eolian minerals.

Newberry (1889) thought that the bone beds were deep water based on what he thought was abrasion due to mastication. This hypothesis should not be discounted since all of the bone bed material is disarticulated. Well-preserved material appears in the calcareous layers above.

Unfortunately, few, conclusive interpretations can be made from the bone bed. The fauna of the bone bed is limited to agnathans, acanthodians, Ohioaspis, and Onychodus, with Onychodus being the only taxon present as macrofaunal remains. No placoderms other than Ohioaspis have been reported from the bone beds, but they are common in the units above. This discrepancy could mean several things. Onychodus was the only predator in deep waters, preying on benthic agnathans and filter feeding acanthodians. Its own teeth and scales would fall off and become incorporated into the sediment, and its waste products would include the scales of the fish upon which it preyed. However, no other Delaware fishes represented by macroremains are found in the beds, indicating that Onychodus would have only fed on particular species.

Another predator could have been mobile, feeding in one area, but living in another. Its prey could be taxa from another region, but its feces would be expelled in the waters of the Delaware. It may have had a preference for agnathans, acanthodians, and Onychodus, all much less armored than the placoderms. This would explain the uniqueness of the fauna and the absence of more familiar Delaware fishes. However, it seems unlikely that another fish capable of feeding on something as large as Onychodus would escape discovery. In addition, the scales represent form genera, and may belong to only a few species

It is likely that the origin of the bone bed fauna is simply a matter of anatomy and sorting. Placoderms, Onychodus, and Machaeracanthus are represented in the Delaware by bony plates, with agnathans, Onychodus, and acanthodians represented in the bone beds by scales or teeth. The sutures and overlying flesh of the placoderm bones are enough to keep them articulated for some time after death and they are relatively large to begin with. Scales, by nature, are highly deciduous and probably fell off readily or were isolated by the decay of the flesh. Scales are much smaller than bony elements, so were probably washed in by the flooding event. Even the smallest placoderm, Onychodus, and Machaeracanthus bones would have been too heavy to be carried by the currents, the tessarae of the placoderm Ohioaspis being an exception. The agnathan, onychodontid and acanthodian taxa certainly lived along side the placoderms, but the latter are not preserved as microremains because of the nature of their external armament. 
Each bone bed within the Delaware marks a flooding event, though most were probably localized. The limestone was deepening in pulses. This may have begun in the upper portions of the Columbus where at least one bone bed was reported (Wells, 1947), though the fact that the waters remained shallow in the units above may indicate that the bone bed represents a current lag deposit in this instance. Much less research has been conducted on this unit that is not traceable across the state. The deepening of the Delaware continued to the top of the formation. An unconformity there represents the last flooding of the Eifelian, an event that resulted in the deposition of the overlying shales.

Onondaga

In western New York, a similar pattern occurred, though the Onondaga was in deeper waters. Once again, all of the Eifelian units were shallow shelf deposits and terms such as "deep" and "shallow" are relative to surrounding units.

The late Edgecliff was a time of considerable energy. The rocks are coarse-grained with numerous fossil fragments and the upper surface is marked by large ripples. Near the top, tabulate corals are in place, but rugose corals have been overturned. Delicate corals dominate the lower units and would be destroyed by high energy levels. From the lack of delicate corals and the overturning of rugose corals in the upper units, it can be concluded that the Edgecliff was shallowing upwards.

The unit above, the Clarence, is a low energy environment, indicating that atop the Edgecliff there is a major flooding surface. There is nothing to indicate that the member was lagoonal, so a deep environment is assumed. The rugose corals found within the unit were well into the section, indicating that they were not eroded from the Edgecliff, but that the Clarence was shallow enough for a few corals to survive. The presence of a phacopsid trilobite and algae indicate that the unit was within the photic zone.

Koch's (1981) hypothesis that the Nedrow was deposited during a regression does not hold up to further scrutiny. He thought that a sea level lowering would cause a cessation of carbonate production, leaving only shaly material to be deposited. Two lines of evidence eliminate this idea from consideration.

First, there is no evidence of a regression in the Clarence. The unit is fine-grained, but not shaly. In the case of a transgression, units basinward, such as the Nedrow, would be more shaly, but units shoreward, such as the Clarence, would be less shaly. Furthermore, the coral bed within the Clarence represents a topographic high where carbonate production is apparent.

Second, there is no report of subaerial exposure on the tops of the Edgecliff reefs. Reports indicated that the reefs were above wave base, but not at sea level (Lindemann, 1989) and that the Nedrow, and even parts of the Moorehouse, were deposited around the topographically high structures (Van Tyne, 1996). Nor is there any report of subaerial exposure of any contemporaneous units in adjacent states. This hypothesis relied heavily on the correlation of the Nedrow with the Lucas, an idea no longer valid (Rickard, 1984).

The lower and upper units of the Clarence are very similar except for the color of the limestone and the chert. A phytoplankton bloom may have ended in late Clarence time, thus decreasing the amount of organic material available to darken the rocks. The coral bed bisecting the upper Clarence is the result of a topographic high, but it is unrelated to the coral bed in Ohio. The corals in Ohio are Edgecliff age, and those in New York are of upper 
Columbus age. In addition, although it can be traced across the quarry, the bed has not been reported elsewhere. The topographic high disappeared and the unit above the coral zone returned to the conditions below. Because that unit is more fossiliferous, however, in can be concluded that the waters were slightly shallower after the topographic high than they were before.

The lower part of the Moorehouse is a transitional zone between the Clarence and the characteristic Moorehouse. The unit is nearly identical to the upper Clarence below, but grain size is greater and fossils are more numerous. It represents a shallowing that began in the upper Clarence because the unit above, while deeper than the transitional zone, is not as deep as the Clarence and was capable of supporting an abundant and diverse calcareous fauna. The transitional zone's shallow nature and its faunal components were similar to that of the Edgecliff. Mesolella (1978) and Rickard (1981) both noted that the upper units of the Nedrow were starting to return to Edgecliff conditions.

The classic Moorehouse is fine-grained, with dark chert, shaly partings, and pyrite. This marks a gradual migration into deeper waters. The shaly partings and pyrite are more common near the top indicating that the upper section was deeper than the lower section. Presumably, this flooding surface is what Brett and Ver Straeten (1994) referred to as an unconformity.

The deepening continued to the top of the Seneca. The light-colored, coarse-grained base of the member was probably deposited as a sand bar or shoal surrounded by deeper waters. This facies disappears upsection at which time the rock darkens and fossils are more indicative of low-diversity, impoverished faunas. Above the Seneca is an unconformity and deep-water shales. In western New York, the Seneca does not mark a return to Nedrow/Clarence conditions since the lithologies and faunas are different, though their paleobathymetries may have been similar. The differences may be due to the rapidity of the deepening rather than the depth.

There is an obvious mixing of faunas between each subsequent member of the Onondaga. This indicates that the change in energy levels from the Edgecliff to the Nedrow to the Moorehouse was also a gradual one (Oliver, 1956a). Toward the top of the Moorehouse, levels of mud increase (Oliver, 1954), the habitat becomes marginal, and brachiopods become numerous, though not diverse, until the end of the Seneca (Oliver, 1956a). This would support a deepening throughout the time of the late Moorehouse and the early Seneca. The transition from the end of the Onondaga to the beginning of the Marcellus was probably rapid (Oliver, 1956a), though not abrupt, (Oliver, 1954) and interfingering between the two formations may occur (Swartz and Swain, 1941).

Brett and Ver Straeten (1995) provided the most compatible study of the Onondaga. They noted that shales of the upper Nedrow marked the maximum flooding surface of a transgression systems tract that originated at the base of the Edgecliff. Above the surface, the lower Moorehouse shallows before returning to deeper conditions in the upper units. The flooding surface of the second transgression is represented by the bone beds near the top of the Seneca. There are no reports of a bone bed at the Moorehouse-Seneca boundary as there is for the coeval Columbus-Delaware contact.

This fits well with what was observed in western New York. However, facies changes are gradational and faunal turnover is minimal. Large-scale models such as the Transgressive Systems Tract model should not be used to describe such subtle changes within the formation. The use of allo-units to describe these changes seems more 
appropriate. The maximum flooding surface of the upper Nedrow is difficult to place in the Cheektowaga Quarry, however, due to the gradational nature of the Clarence and Moorehouse. The major flooding surface of the lower Onondaga in western New York appeared to have occurred at the base of the Clarence. A shallowing occurred in the lower Moorehouse due to sediment aggradation rather than a drop in sea level. This shallowing trend began in the rocks of the central Nedrow prior to the deposition of the Moorehouse. The subsequent deepening of the upper units was not abrupt and no unconformity was noted in the outcrop. The flooding in the Seneca was not as pronounced as it was in the Delaware because the Seneca was already a deep-water facies.

Eastern New York may have been more stable that western New York. This allowed for continuous sedimentation and the formation of reefs. The eastern units were surrounded by basins, but facies changes were subtle. In the west, there was a gradual slope that originated in the deeper "basinal" units and extended into shallow shelf environments. Minor tectonic changes in the basin caused slight changes in facies. This explains the gradational nature of the Onondaga and the homogeneity of the faunas throughout. Zaphrentids, styliolinids, cephalopods, and gastropods are certainly more common in finer-grained units, but there is considerable overlap among brachiopods and between the assemblages of subjacent units. The overlap indicates that the changes in facies were subtle enough to change some faunal components, but not abrupt enough to change others. It may also reflect the biased nature of Onondaga studies. Brachiopods have been studied extensively, but other faunal constituents are often ignored due to their minor presence in some horizons.

Bryozoans and crinoids are numerous in most units, but are not useful for biostratigraphy due to their highly fragmentary condition.

The presence of calcareous algae nullifies the idea that the Onondaga Sea was a cool water habitat. The algae were found in the Clarence, a deep-water facies, indicating that even the deepest western Onondaga habitat was warm enough and illuminated enough to support algae. This may not be true for the eastern and central units where many studies have occurred. The detection of algae in this study was extremely serendipitous. It is likely that algae occurs in other units but has not been reported from the Moorehouse because it has never been found. It was reported from extremely fossiliferous units of the Edgecliff by Bruner and Smosna (2002). It did not grow in the central units of the Nedrow because the water was too deep. Algae was never found in the Onondaga, apparently, because no one ever looked in the Clarence, a unit that is not too deep but is isolated enough for calcareous algae to survive. If Devonian corals possessed zooxanthellae, they would be further evidence that even the deepest units of the western Onondaga were deposited in a shallow, clear, warm, and well-lit sea, since rugose corals were found in the Clarence.

The idea that the Onondaga Formation was deposited in a warm, shallow sea seems to be the most logical explanation. The deepest units of the formation were shallow enough to support at least a few corals and algae. In addition, the Onondaga of western New York was deposited in an epeiric sea, a body of water characterized by shallow bathymetries. Shallow waters are warmer than deeper bodies. Hunicken et al. (1988) found that conodonts were rare in cold-water faunas of the Eifelian of Gondwana, but abundant in the contemporary units of North America. Ptyctodonts are not found in the cold water Malvinokaffric faunas of Gondwana, but are numerous in North America. This could be due to a preference for warm seas by ptyctodonts, although it may be more related to dispersal barriers. 
Ohio was shallower and slightly closer to the equator than New York. There is an obvious trend in the increase in the abundance and diversity of stromatoporoids closer to the paleoequator. The scarcity of stromatoporoids in the Onondaga, however, may be due to factors other than temperature. The conditions of the Onondaga may have been less than ideal for stromatoporoids, but ideal for corals. The establishment of corals may have prevented the establishment of other taxa. This explains the absence of stromatoporoids in the east, where corals are most prevalent, and their occasional presence in the western part of the state where corals never reach the faunal levels of the eastern section.

Fish

Originally, the fishes from the Buffalo Museum of Science and the Cleveland Museum of Natural History represented 41 taxa. However, most of these were misidentified, synonymized, or possessed invalid nomenclature. At the end of this study, the fish taxa in the two museums had been reduced to nine valid species. The only genus that was not positively identified in both regions was Eczematolepis, a taxon of questionable affinity.

All of the fish examined in the two museums came from the upper Columbus, Delaware, upper Moorehouse, lower Moorehouse or Seneca. In other words, from the uppermost units of the quarries that were mined by hand over 100 years ago. Most likely, the fish occurred in other units, but are never recovered because workers no longer quarry by hand. Large machines rip through rock and workers never get the chance to examine the rock for fossils. The collection of the fossils dates to a time around the start of the quarries when the upper units would have been the first to be quarried, and manual techniques helped to insure that vertebrate fossils were neither destroyed nor overlooked.

Facies changes affected lithologies, but there was a great deal of overlap among invertebrate taxa. The same was probably true for vertebrates. The difference between a shallow-water unit and a deep-water unit may have been insignificant enough that it did not affect the fishes. However, there are some patterns.

The Australian form of Onychodus has been associated with reef structure. However, the North American form was most common in the deeper waters of the Delaware and the upper Moorehouse. Corals are not common in either, certainly not to the point of forming any sort of biostromal complex that would provide a large fish shelter to ambush prey. The upper Moorehouse is characterized by brachiopods, which may have been the prey items of durophagous ptyctodonts. These placoderms, in turn, may have been the prey of Onychodus. Onychodus fossils from this unit are always associated with very thin shale partings. In the Delaware, Onychodus occurs as scales in the bone beds where no carbonate material is found and in the overlying units, as teeth and cranial bones, where corals are rare and crinoids are small. It seems the North America Onychodus was not a shallow-water reef dweller, but a mobile predator capable of moving through environments, more similar to modern sharks than modern eels. This may warrant their placement within a different species as that of the Australia form, though more material must be recovered and properly studied.

The area in which Onychodus lived was still not deep, nor was it the open ocean. The shelf was within the photic zone, but well below wave, and possibly, storm base. Prey items would have been most common in shallower waters. This may explain why Onychodus was more common in the Ohio region than in New York. 
Tentaculites, a benthic form, was almost always found with Onychodus, indicating that it preferred the softer substrates of deeper waters. Tentaculites was found in most of the units of Ohio, particularly the Delaware, but only in the deeper waters of the Onondaga. The occurrence of the tax on in shallow units indicates that the enigmatic organism may have possessed a habitat preference independent or indirectly related to water depth.

Macropetalichthys is found in units associated with shoals, but surrounded by deeper waters. The upper Columbus and Seneca contained shoals, but also underwent deepening events. The lower Moorehouse was the result of a shallowing, but was surrounded by deeper units. The Delaware, where the best fossils were collected, was a deep-water formation. These fossils are incredibly well preserved, so did not travel far. Because no dental plates have ever been recovered, the feeding strategy of petalichthyids is unknown. However, it is evident that Macropetalichthys was a benthic form and benthic forms do not tend to move around much (Wheeler, 1975). It may have lived on the edge of shoals where it could maximize its prey capture. The units in which it is found are usually coarse-grained, even in the Delaware where Tentaculites litters the matrices of the museum specimens.

Macropetalichthys was not a detritus feeder since benthic vertebrates rarely exhibit such a feeding strategy. The placoderm was probably a durophage. Perhaps the dental plates of Ptyctodus, a large, distinctly crushing form, are those of Macropetalichthys.

Machaeracanthus was an open-shelf predator. Its teeth are those of predatory forms and its presence in the rocks of the Delaware, uppermost Moorehouse and Seneca shows a preference for deeper waters, suggesting a fusiform, free-swimming fish.

Ptyctodonts dominated the fish collections at both museums in terms of both numbers and diversity and were most diverse during the Eifelian in the eastern United States. Of the ten described Eifelian species of ptyctodonts, eight occurred in the Onondaga, Columbus and Delaware. The only other Eifelian ptyctodonts occurred in Germany. The faunas of other Eifelian locales and the more recent units of the Middle Devonian are dominated by arthrodires, open water predators. Ptyctodonts are thought to have been benthonic forms (Denison, 1978) preferring shallower waters where prey was abundant and predators rare.

The ptyctodont Deinodus ohioensis is first described in this paper. Deinodus ohioensis is the only ptyctodont that does not occur in deeper-water units. The other taxa, whether their dentition was used for crushing or shearing, probably stayed close to the bottom, but were capable of short trips into the water column. Ptyctodonts possess much less armor than other placoderms, and may have had greater mobility as a result, contrary to earlier hypotheses.

Deinodus ohioensis, however, preferred the shallow waters of the Columbus. This supports the claim that $D$. ohioensis was smaller than the New York species, D. bennetti. The size discrepancy could be the result of ontogeny or phylogeny. The shallower habitat would provide a nursery for juvenile fish, as it does for modern sharks and game fish (Gilbert, 1963; Dodson, 1997), or protection for the smaller species.

\section{Sedimentology and Stratigraphy}

\section{CONCLUSIONS}

Both the Columbus Limestone and the Onondaga Formation are marked by cycles of shoaling upwards and relative sea level rise. Alternating shoaling and flooding events explain how the Columbus can seem like a regressional unit while the Onondaga seems 
transgressional. It seems unlikely that the Columbus could have been regressing while the Onondaga was transgressing.

The base of the Columbus is a deeper water deposit that shallows upward until a significant coral biostrome is formed. A slight rise in sea level drowns the coral bed and conditions were very similar to the way they were before the coral was established. This inundation is probably the same flooding that Leonard (1996) used to mark his first Systems Tract boundary, atop Allo-unit 2.

Throughout the upper Columbus, aggradation continues through a fossil rich zone, to a hash layer with tidalites near the top. The coarse layer at the top of the Columbus in the Warrensburg Quarry, the one resembling the units of the upper Moorehouse, may mark a second, very minor flooding event. Leonard (1996) reported a second flooding event lower in the Jeffersonville that was not observed in the Columbus. However, he indicated possible flooding higher in the section, approximately where the coarse layer of the upper Columbus is located.

The next flooding event, more intense than the first two, floods the Columbus, begins the deposition of the Delaware and deposits the most significant bone bed, the only one traceable across the state. This event also deposited the North Vernon above the Jeffersonville in Indiana (Leonard, 1996). Two more flooding events occur before the Eifelian of Ohio is inundated by the deep waters of the units above.

A similar sequence of events occurred in western New York, but due to a greater range in water depths, the results were more pronounced. The top of the Edgecliff was probably the result of shoaling that had begun at the time of the initial Onondagan transgression. The first flooding event marked the deposition of the deep water Clarence Member. This inundation may be the same relative sea level rise that covered the coral bed in the lower Columbus.

The Clarence aggraded slowly, becoming more fossiliferous, coarser-grained, and lighter in color until a time in the early Moorehouse when a second flooding event formed the fine-grained and darker upper Moorehouse and its shaly partings. This sea level rise would have been very gradual, and it may have affected the upper Columbus, depositing the uppermost coarse layer, or it may not have extended into Ohio at all. A more detailed study at the Sandusky Quarry, where the upper Columbus is more like the Moorehouse, might help to understand the effects of the sea level rise.

The presence of algae in the Clarence indicates that the member was deposited within the photic zone. The lack of algae in the Nedrow may indicate that the Clarence was a shallower water deposit, though algae may be in the former, but not yet discovered.

The shoaling that occurred in the lower Seneca was short-lived because a third flooding event deposited the Seneca bone bed and deeper waters prevailed once again. The shoaling would have been more rapid than the sea level rise at first, but was overtaken with time. This shallowing explains why the Seneca bone bed is higher in section than the major bed of the Delaware even though the bases of the two units are marked by the Tioga Bentonite. The flooding that formed the overlying black shales was the final flooding event.

Throughout the deposition of the Columbus and Onondaga Limestones, sea level rise was very slow and subtle, so the term, 'transgression', usually implying long-lived or quick rises in sea level, may be a bit extreme. The North American Eifelian events may have occurred over a large area, but the seas were shallow enough that the result was not extreme. The change in lithology was extremely gradual, especially in the upper Moorehouse, so that 
considering the flooding a transgression seems misleading. Calling the events 'relative sealevel rises' does not imply the drastic changes usually associated with transgressions.

The Onondaga, Columbus, and Delaware Limestones were deposited at about $35^{\circ}$ south latitude, a region well outside of the tropical range of modern seas. However, the shallowness of the epeiric sea and the lack of polar ice may have kept the waters much warmer than occurs today at such a latitude. The presence of algae, and possibly corals, confirms that the units were within the photic zone and may support this claim of a tropical sea. It seems likely that tropical seas extended to much higher latitudes in the Eifelian, probably well beyond $35^{\circ}$.

\section{Paleoecology}

The lack of identifiable invertebrate fossils associated with the museum specimens limits their utility in paleoecological reconstruction. However, the identification of Acrospirifer duodenaria, Leptaena sp. A and Atrypa "reticularis" in many of the upper Moorehouse specimens were used to verify the placement of the fish in that unit.

Nine valid species of Eifelian fishes were found in the collections of the Buffalo Museum of Science and the Cleveland Museum of Natural History, and eight of the nine taxa occurred in both museums. Most of the fishes of the Onondaga came from the upper Moorehouse with only a few coming from the lower Seneca. This distribution indicates that the fishes of the Onondaga may have been associated with the Atrypa-Megakozlowskiella, Atrypa-Levenea, Leptaena-Megakozlowskiella and Atrypa-Coelospira-Nucleospira biozones of Feldman (1985) and biozones G-I of Oliver (1954). However, there is considerable overlap of invertebrate taxa and no biostratigraphic studies have been conducted on the rocks of western New York.

The fishes collected in the Eifelian units of Ohio were from the upper Columbus and the Delaware. Unfortunately, there are no biozone studies available to assist in the paleoecological interpretations of the fishes.

\section{$\underline{\text { Inferences Based on Depositional Environments }}$}

The Eifelian seas of North America were shallow and warm, and probably around 35 degrees south latitude. The waters were at a latitude represented by a temperate zone in modern seas, but would have been warmer due to the shallowness of the sea and the absence of ice caps. The shallow nature meant that subtle sea level changes lead to facies shifts, but had very little effect on the fauna. The seas of Ohio were slightly shallower than those of New York, and possessed less organic matter. The Onondaga and the Delaware culminated in a flooding event, and their terminal units are overlain by black shales, a facies dominated by arthrodires, open water predators.

The fishes of the Eifelian lived in the deeper water facies, the lone exception being Deinodus ohioensis. The distribution of the fishes was a function of prey availability rather than habitat limitations. Ptyctodonts were the dominant fish form, most feeding by crushing invertebrates, but may have been preyed upon by Onychodus and Machaeracanthus. Macropetalichthys remained close to the bottom and may also have been a prey item for larger fishes. Ptyctodonts such as Rhynchodus may have turned the tables on Onychodus and Machaeracanthus and fed on them. 


\section{Functional Morphology}

The dorsoventrally compressed body form of Macropetalichthys indicates that it spent most of its time on or near the bottom, though its feeding habits are unknown because dentary structures have never been found. The fish could have been a filter or detrital feeder with reduced jaws, or, more likely, the jaws belong to one of the ptyctodont form species known only from jaw parts.

Because they were durophages, Palaeomylus and Ptyctodus probably stayed close to the bottom. Presumably, this would be where most of the prey lived. In contrast, Rhynchodus, which resemble Palaeomylus, was a shearer and would have preyed on softbodied invertebrates and other fishes. Relative to the arthrodires, all of the ptyctodonts stayed in shallow waters.

The feeding habits of the two Deinodus species and Eczematolepis cannot be determined. The Deinodus dental surfaces could not be viewed and Eczematolepis is a questionable taxon. Deinodus was definitely a shelf form because it only occurs in the Eifelian rocks of Ohio and New York. Deinodus was probably a ptyctodont and was probably a durophage. However, it is worth considering that Deinodus may have been a transitional form between the ptyctodonts and the petalichthyids.

Machaeracanthus and Onychodus were the two large predators of the North American Eifelian and moved back and forth between deeper and shallower waters in search of prey. Both were extremely large for Eifelian fishes and both possessed elongate jaws with large teeth that terminated in a tooth whorl designed for snagging passing prey. They were mobile predators because there were no reefs or bioherms enabling them to ambush prey. The identification of the Machaeracanthus tooth whorl validates their placement within the Ischnacanthidae family of Ischnacanthiformes.

\section{Comparison with other Fish Faunas}

It is difficult to compare the Eifelian fish faunas of eastern North America to those of other areas. All of the fish fossils were found in horizons deposited toward the end of the stage after provincial boundaries were eliminated, but the species are apparently unique to the region. Figure 5, a paleogeographic map of the Eifelian, shows that eastern North America was isolated by the Appalachian Mountains and deep seaways, prohibiting or inhibiting the migration of species.

The genera present in the Eifelian are found in other regions and other stages (Denison, 1978), but the species of the Onondaga, Columbus, and Delaware Limestones are unique to those units. The exceptions to this are Eczematolepis fragilis and Onychodus sigmoides, the latter a species that occurs in Australia, also. Eczematolepis fragilis extends into the Frasnian, but the taxon is so poorly defined that more research needs to be conducted to determine if this is a true geologic range. The teeth and tooth whorls of the North American and Australian Onychodus are very similar, but due to such a wide separation and unique habitat preferences, it seems likely that the two forms are different species. Palaeomylus, Rhynchodus, and Ptyctodus have all been reported from the North Evans Limestone (Frasnian), located just to the southwest of Buffalo, New York, and may represent 
the descendents of the Eifelian forms. The North Evans is called the Conodont bed in earlier literature and is now considered part of the Genesee Group of the Givetian/Frasnian.

The Jeffersonville Limestone has been shown to be very similar in its lithology and depositional history to the Columbus, Delaware, and Onondaga Limestones, and the four formations are correlative. Therefore, it makes sense that the Jeffersonville fish fauna is similar to the other North American Eifelian fish faunas. Macropetalichthys sullivanti and Rhynchodus sp. were found in that unit (Denison, 1978). Macropetalichthys sullivanti is only found in the Eifelian of North America, and the Rhynchodus is likely R. secans, the only form found in the United States during the stage (Denison, 1978). Ohioaspis tumulosus is also found in both Indiana and Ohio, though it was not found in this study. Wells (1944) reported that bone beds within the Jeffersonville were the same as those of the Columbus and Delaware. The Grand Tower Formation of Missouri and Illinois is the same age and lithology as the Jeffersonville (Devera and Fraunfelter, 1988), but has not yet produced any fish (Denison, 1978).

Other parts of the world, particularly north-central Asia, produce a diverse Eifelian fauna of arthrodires, a taxon relatively rare in the coeval units of eastern North America. Presumably, the shallower waters of the Onondaga, Columbus and Delaware seas were better suited for ptyctodonts, Macropetalichthys, and Onychodus, forms that probably remained close to the sea floor, than they were for arthrodires, forms that were more likely open water predators (Denison, 1978). Machaeracanthus, the only deeper-water predator of the North American Eifelian fishes, was mobile and sought prey in shallow waters.

\section{$\underline{\text { Taxonomic Revision }}$}

Numerous taxonomic revisions resulted from this study. Because Macropetalichthys rapheidolabis is a nomen nudum, Macropetalichthys sullivanti is now the only valid species of petalichthyid in the Eifelian of North America. There was no character that distinguished Machaeracanthus major and $M$. peracutus other than size. Due to a lack of a diagnostic character, M. major is considered a junior synonym of M. peracutus. Machaeracanthus is formally placed within the Ischnacanthidae and the Ischnacanthiformes.

It seems unlikely that the Onychodus sigmoides of Australia is the same Onychodus sigmoides of North America. Better, more complete specimens need to be found to reevaluate the North American form. Until such material is found, the North American variety shall continue to be identified as $O$. sigmoides.

The numerous species of Rhynchodus found on museum specimen labels have been placed in the species, Rhynchodus secans. This is not of much consequence, however, since none of the other species were ever formalized. This is the case for many of the spurious taxa that appear on the specimen cards of the Cleveland Museum.

The genus Deinodus is considered to be a ptyctodont and formally placed in the family, Ptyctodontidae. This is based on the ptyctodont-like anterior ventrolateral plates and dental elements. The spines of Deinodus are very similar to that of some petalichthyids, a group for which dental elements have never been found, indicating that Deinodus may be a transitional form between the two groups. Deinodus ohioensis is described as a small form genus from the Columbus Limestone of Ohio.

This study presents new information on the paleoecology and diversity of Eifelian fishes in eastern North America. More work needs to be conducted Eifelian fishes from 
other North American localities. In addition, well-preserved, fully articulated specimens would help to identify the function and taxonomy of many of the remaining unidentified specimens. However, the present study provides information on the habitat and bathymetry preference of the North American Eifelian fishes and helps the Buffalo Museum of Science and the Cleveland Museum of Natural History to correctly identify many erroneous and unknown specimens.

\section{References Cited}

Bailey, J.B. 1983. Middle Devonian Bivalvia from the Solsville Member (Marcellus Formation), central New York State. Bulletin of the American Museum of Natural History 174(3): 193- 325.

Baschnagel, R.A. 1942. Some microfossils from the Onondaga chert of central New York. Bulletin of the Buffalo Society of Natural Sciences 17(3): 1-8.

Bassler, R.S. 1941. Ostracoda from the Devonian (Onondaga) chert of western Tennessee. Journal of the Washington Academy of Sciences 31(1): 21-27.

Bentley, R. 1988. Fish fauna from the second Middle Devonian bone bed of central Ohio (Eiffelian [sic]). Senior Thesis, Ohio State University Geological Sciences.

Bergstrom. S. M. 1996. Tentaculitoids. In: Feldman, R.M. Fossils of Ohio. Ohio Division of Geological Survey, Bulletin 70, Columbus. 577 pages.

Blieck, A., E. Mark-Kurik, and T. Marrs. 1988. Biostratigraphical correlations between Siluro- Devonian invertebrate-dominated and vertebrate-dominated sequences in the east Baltic example. In: McMillan, N.J., A.F. Embry and D.J. Glass. Devonian of the World, vol. III: Paleontology, paleoecology and biostratigraphy. Canadian Society of Petroleum Geologists, Calgary, AB. pp. 579-588.

Boucot, A.J. 1988. Devonian biostratigraphy: an update. In: McMillan, N.J., A.F. Embry and D.J. Glass. Devonian of the World, vol. III: Paleontology, Paleoecology and Biostratigraphy. Canadian Society of Petroleum Geologists, Calgary, AB. pp. 211228.

Brett, C. and C. Ver Straeten. 1994. Stratigraphy and facies relationships of the Eifelian Onondaga Limestone (Middle Devonian) in western and west central New York State. Field Trip Guidebook, New York State Geological Association, 66th Annual Meeting, pp. 221-270.

Brett C. E. and C.A. Ver Straeten. 1995. Middle Devonian (Eifelian) carbonates, northern and central Appalachian Basin; sequence stratigraphic framework. American Association of Petroleum Geologists Bulletin 79(9): 1410-1411.

Bruner, K and R. Smosna. 2002. Cherty sponge reefs in the Devonian Onondaga Limestone: newly discovered gas reservoir in Pennsylvania. Northeastern Geology and Environmental Sciences. 7 pages.

Buehler, E.J. and I.H. Tesmer. 1963. Geology of Erie County, New York. Buffalo Society of Natural Sciences Bulletin 21(3): 118 pp.

Carr, R.K. 1995. Placoderm diversity and evolution. Bulletin of the Museum of Natural History, Paris 17(1-4): 85-125.

Clarkson, E.N.K. 1986. Invertebrate Palaeontology and Evolution. Chapman and Hall, London. 434 pages. 
Cooper, G.A., C. Butts, K.E. Caster, G.H. Chadwick, W. Goldring, E.M. Kindle, E. Kirk, C.W. Merriam, F.M. Swartz, P.S. Warren, A.S. Warthin, and B. Willard. 1942. Correlation of the Devonian Sedimentary Formation of North America Geological Society of America Bulletin 53: 1729-1794.

Dennison, J.M. 1961. Stratigraphy of Onesquethaw Stage of Devonian in West Virginia and bordering states. West Virginian Geologic Survey Bulletin 22. 87 pages.

Denison, R. 1978. Placodermi. In: Schultze, H.P. ed. Handbook of Paleoichthyology vol. 2. Gustav Fischer Verlag, Stuttgart. 128 pages.

Denison, R. 1979. Acanthodii. In: Schultze, H.P. ed. Handbook of Paleoichthyology vol. 5. Gustav Fischer Verlag, Stuttgart. 62 pages.

Devera, J.A. and G.H. Fraunfelter. 1988. Middle Devonian paleogeography and tectonic relationships east of the Ozark Dome, southeastern Missouri, southwestern Illinois and parts of southwestern Indiana and western Kentucky. In: McMillan, N.J., A.F. Embry, and D.J. Glass. Devonian of the World, vol. II: Paleontology, Paleoecology and Biostratigraphy. Canadian Society of Petroleum Geologists, Calgary, AB.

Dineley, D.L. and E.J. Loeffler. 1993. Biostratigraphy of the Silurian and Devonian gnathostomes of the Euramerican Province In: Long, J.A. Palaeozoic Vertebrate Biostratigraphy and Biogeography. Johns Hopkins Press, Baltimore, Maryland. 370 pages.

Dodson, J.J. 1997. Fish Migration: An Evolutionary Perspective. In: Godin, J-G. J. Behavioral Ecology of Teleost Fishes. Oxford University Press, Oxford. 384 pages.

Dutro, J.T. 1981. Devonian brachiopod biostratigraphy of New York State. In: Oliver, W.A. and G. Klapper. Devonian Biostratigraphy of New York; part 1, text. pp. 6782.

Fagerstrom, J.A. 1966. Biostratigraphic significance of rhipidomellid brachiopods in the Detroit River Group (Devonian). Journal of Paleontology 40(5): 1236-1238.

Fagerstrom, J.A. 1961. The fauna of the Middle Devonian Formosa reef limestone of southwestern Ontario. Journal of Paleontology 35(1): 1-48.

Feldman, H.R. 1980. Level-bottom brachiopod communities in the Middle Devonian of New York. Lethaia 13(1): 27-46.

Feldman, H.R. 1985. Brachiopods of the Onondaga Limestone in central and southeastern New York. Bulletin of the American Museum of Natural History 179(3): 293-377.

Feldman, H.R. 1994. Brachiopods of the Onondaga Formation, Moorehouse member (Devonian, Eifelian), in the Genesee Valley, Western New York Bulletins of American Paleontology 107(346): 56 pages.

Forsyth, J.L. 1988. The uniqueness of the Devonian Columbus Limestone of Ohio. Ohio Journal of Science 88(2): 14.

Friedman, G.M. 1995. Onondaga pinnacle reefs in New York State. American Association of Petroleum Geologists Bulletin 79(9): 1413

Friedman, G.M. 1985. Devonian reefs of New York. Northeastern Geology 7(2): 117-125.

Fritz, M.A. 1940. Aparchites canadensis, a new Devonian ostracode from the Onondaga of Ontario. Journal of Paleontology 14(1): 77-78.

Geological Society of America. 1999. Geologic Time Scale. Geological Society of America, Denver, CO. 1 page.

Gilbert, P.W. 1963. Sharks and Survival. D.C. Heath and Co., Boston. 578 pages.

Gurney, G.G. and G.M. Friedman. 1987. Burial history of the Devonian Cherry Valley 
carbonate sequence, Cherry Valley, New York. Northeastern Geology 9(1): 1-11

Gurney, G.G. and G.M. Friedman. 1986. Transgressive-regressive cycles in vertical sequences; an example from Devonian carbonates in Cherry Valley, New York. Northeastern Geology 8(4): 201-217.

Hasson, K.O. and J. M. Dennison. 1988. Devonian shale lithostratigraphy, central Appalachians, USA. In: McMillan, N.J., A.F. Embry and D.J. Glass. Devonian of the world, vol. III: Paleontology, paleoecology and biostratigraphy. Canadian Society of Petroleum Geologists, Calgary, AB. pp. 157-177

Hayward, W.C. 1984. Subsurface stratigraphy of Upper Cambrian through Carboniferous rocks in western and central Pennsylvania. American Association of Petroleum Geologists Bulletin 68(12): 1920.

Hess, H., W.I. Ausich, C.E. Brett and M.J. Simms. 1999. Fossil Crinoids. Cambridge University Press. 275 pages.

Hill, D. 1956. Rugosa. In: Moore, R.C. Treatise on Invertebrate Paleontology: Part F, Coelenterata (Cnidaria). Geological Society of America, University of Kansas Press, Lawrence. 498 pages.

Hoare, R.D. 1989. Taxonomy and paleoecology of Devonian rostroconch molluscs from Ohio. Journal of Paleontology 63(6): 838-846.

House, M.R. 1962. Observations on the ammonoid succession of the North American Devonian. Journal of Paleontology 36(2): 247-284.

Hunicken, M.A., J.H. Goncalves de Melo and V. Brasil Lemos. 1988. Devonian conodonts from the upper Amazon Basin, northwestern Brazil. In: McMillan, N.J., A.F. Embry, and D.J. Glass. Devonian of the World, vol. III: Paleontology, Paleoecology and Biostratigraphy. Canadian Society of Petroleum Geologists, Calgary, AB. pp. 479484.

Hussakof, L. and W.L. Bryant. 1918. Catalog of fossil fishes in the Museum of the Buffalo Society of Natural Sciences. Bulletin of the Buffalo Society of Natural Sciences 17:18-22. Janvier, P. 1998. Early Vertebrates. Oxford University Press, Oxford. 393 pages.

Jenkins, W.A.M. and J.A. Legault. 1979. Stratigraphic ranges of selected Chitinozoa. Palynology 3: 235-264.

Kent, D.V. 1979. Paleomagnetism of the Devonian Onondaga Limestone revisited. Journal of Geophysical Research 84(B7):3576-3588.

Kent, D.V. and N.D. Opdyke. 1977. Discordant Devonian and Mississippian paleomagnetic poles for North America as evidence for two Paleozoic plates. Eos 58(8): 745.

Kindle, E.M. 1912. The Onondaga Fauna of the Alleghany region. United States Geological Survey Bulletin 508. 116 pages.

Kindle, E.M. 1913. The unconformity at the base of the Onondaga Limestone in New York and its equivalent west of Buffalo. Journal of Geology pp. 301-319.

Kirchgasser, W.J., G.C. Baird, and C.E. Brett. 1988. Regional placement of Middle/Upper Devonian (Givetian-Frasnian) boundary in western New York state. In: McMillan, N.J., A.F. Embry, and D.J. Glass. Devonian of the World, vol. III: Paleontology, Paleoecology and Biostratigraphy. Canadian Society of Petroleum Geologists, Calgary, AB. pp. 113-117.

Klapper, G. 1981. In: Oliver, W.A. and G. Klapper. Devonian biostratigraphy of New York; part 1, text. pp. 33-36. 
Koch, W.F. 1981. Brachiopod community paleoecology, paleobiogeography and depositional topography of the Devonian Onondaga Limestone and correlative strata in eastern North America. Lethaia 14(2): 83-103.

Koch, W.F. 1982. Brachiopod community paleoecology, paleobiogeography and depositional topography of Devonian Onondaga Limestone in eastern North America. American Association of Petroleum Geologists Bulletin 66(8): 1170.

Leibe, R.M. and T.X. Grasso. 1990. The Devonian stratigraphy of Cherry Valley, New York. Northeastern Geology 12(1-2): 7-13.

Leonard, K.W. 1996. Sequence stratigraphy of the lower part of the Muscatatuck Group (Middle Devonian) in southeastern Indiana. In: Witzke, B.J., G.A. Ludvigson, and J. Day eds. Paleozoic Sequence Stratigraphy: Geological Society of America Special Paper 306. pp. 243-257.

Lindemann, R.H. 1995. Magnitude of early diagenetic compaction in the Onondaga Limestone of central and eastern New York. American Association of Petroleum Geologists Bulletin 79(9): 1416.

Lindemann, R.H. 1989. The Leroy Bioherm, Onondaga Limestone (Middle Devonian), Western New York In: Geldsetzer, H.H.J., N.P. James, and G.E. Tebutt eds. Reefs, Canada and Adjacent Area. Canadian Society of Petroleum Geologists Memoir 13, pp. 487-491.

Lindemann, R.H. and E.L. Yochelson. 1984. Styliolines from the Onondaga Limestone (Middle Devonian) of New York. Journal of Paleontology 58(5): 1251-1259.

Lindholm, R.C. 1969a. Detrital dolomite in Onondaga limestone (Middle Devonian) of New York; its implications to the 'dolomite question'. American Association of Petroleum Geologists Bulletin 53(5): 1035-1042.

Lindholm, R.C. 1969b. Carbonate petrology of the Onondaga Limestone (Middle Devonian), New York; a case for calcisiltite. Journal of Sedimentary Petrology 39(1): 268-275.

Liu, H., J. Wang, S. Bai and Z. Bai. 1988. Preliminary study on paleomagnetism of the lower-middle Devonian boundary beds from Guangxi, South China. In: McMillan, N.J., A.F. Embry and D.J. Glass. Devonian of the World, vol. III: Paleontology, Paleoecology and Biostratigraphy. Canadian Society of Petroleum Geologists, Calgary, AB. pp. 137-140.

Long, J.A. 1995. The Rise of Fishes. Johns Hopkins University Press, Baltimore, MD. 223 pages.

Long, J.A. 1997. Ptyctodontid fishes (Vertebrata, Placodermi) from the Late Devonian Gogo Formation, Western Australia, with a revision of the European genus Ctenurella Orvig, 1960. Geodiversitas 19(3): 515-555.

Long, J.A. 2001. On the relationships of Psarolepis and the onychodontiform fishes. Journal of Vertebrate Paleontology 12(4): 815-820.

Maisey, J. G. 1996. Discovering Fossil Fishes. Henry Holt, New York. 223 pages.

McGregor, D.C. 1979. Devonian miospores of North America. Palynology 3: 31-52

Mesolella, K.J. 1978. Paleogeography of some Silurian and Devonian reef trends, central Appalachian Basin. American Association of Petroleum Geologists Bulletin 62(9):1607-1644.

Mesolella, K.J. 1966. Collophane associated with the unconformity at the base of the Devonian Onondaga Limestone in New York State. Journal of Sedimentary 
Petrology 36(1): 260- 262.

Nelson, J.S. 1994. Fishes of the World. John Wiley and Sons, New York. 602 pages. New York State Geological Society. 1931. New York State Museum Handbook 10. Handbook of paleontology for beginners and amateurs part 2: the formations. University of the State of New York, Albany. 488 pages.

Newberry, J. S. 1873. Descriptions of Fossil Fishes. pp. 247-358. In: Report of the Geological Survey of Ohio volume 1, part II.. Columbus. 596 pages.

Newton, C.R. 1979. Biofacies patterns in the Needmore Shale: paleoenvironments and paleobathymetry complications. pp. 77-82. In: Avary, K.L. Devonian Clastics in West Virginia and Maryland, Field Trip Guide. American Association of Petroleum Geologists Meeting Bulletin 1979. Morgantown, WV.

Oliver, W.A. 1954. Stratigraphy of the Onondaga Limestone (Devonian) in central New York. Geological Society of America Bulletin 65(7): 621-652.

Oliver, W.A. 1956a. Stratigraphy of the Onondaga Limestone in eastern New York. Geological Society of America Bulletin 67(11): 1441-1474.

Oliver, W.A. 1956b. Tornoceras from the Devonian Onondaga Limestone of New York. Journal of Paleontology 30(2): 402-405.

Oliver, W.A. 1958. Significance of external form in some Onondagan rugose corals; Part 1, compression and depression in some Onondaga corals; Part 2, individual variation in Metriophyllum (Aemulophyllum) exiguum (Billings). Journal of Paleontology 32(5): 815-837.

Oliver, W.A. 1976. Noncystimorph colonial rugose corals of the Onesquethaw and Lower Cazenovia Stages (Lower and Middle Devonian) in New York and adjacent areas. Geological Survey Professional Paper 869, Washington, D.C. 156 pages +108 plates.

Oliver, W.A. 1981. The Middle Devonian rugose coral Prismatophyllum conjunctum (Davis) and the age of the "Columbus" Limestone at Ingersoll, Ontario. Geological Society of America Bulletin 92(11): I 873-I877.

Oliver, W.A. and J.E. Sorauf. 1983. Devonian rugose corals of New York. In: Sorauf, J.E. and W.A. Oliver (eds). Silurian and Devonian corals and stromatoporoids of New York; International Association for the study of Fossil Cnidaria. pp. 35-51.

Patchen, D.G., K.L. Avary and R.B. Erwin. 1985. Northern Appalachian Region. Correlation of Stratigraphic Units of North America (COSUNA) Project. American Association of Petroleum Geologists.

Prosser, C.S., E.M. Kindle and C.K. Swartz. 1913. In: Maryland Geological Survey. Middle and Upper Devonian text. 720 pages.

Prothero, D.R. 1998. Bringing Fossils to Life. WCB McGraw-Hill, Boston. 457 pages.

Reger, D.B. 1924. Mineral and Grant Counties. West Virginia Geological Survey. 866 pages.

Richardson, E.S. 1950. A middle Devonian octactinelled sponge from New York. Fieldiana: Geology 10(10): 79-88.

Rickard, L.V. 1981. The Devonian system of New York State. In: Oliver, W.A. and G. Klapper. Devonian biostratigraphy of New York; part 1, text. pp. 5-21.

Rickard, L.V. 1984. Correlation of the subsurface Lower and Middle Devonian of the Lake Erie region. Geological Society of America Bulletin 95(7): 814-828. 
Rzhonsnitskaya, M.A. 1988. Biostratigraphic scheme of the Devonian of the Russian Platform. In: McMillan, N.J., A.F. Embry, and D.J. Glass. Devonian of the World, vol. III: Paleontology, Paleoecology and Biostratigraphy. Canadian Society of Petroleum Geologists, Calgary, AB. pp. 691-702.

Sarnecka, E. 1988. Tabulata from the uppermost Emsian and the Eifelian of Poland. In: McMillan, N.J., A.F. Embry, and D.J. Glass. Devonian of the world, vol. III:

Paleontology, paleoecology and biostratigraphy. Canadian Society of Petroleum Geologists, Calgary, AB. pp. 425-430.

Savage, T.E. 1910. The Grand Tower (Onondaga) Formation of Illinois and its relation to the Jeffersonville beds of Indiana. Transactions of the Illinois State Academy of Science pp.116-132.

Schuchert, C. 1943. Stratigraphy of the eastern and central United States. John Wiley and Sons, New York. 1013 pages.

Scotese, C.R. 2002. Paleogeography of the Middle Devonian (Eifelian). www.scotese.com.

Selleck, B.W. 1985. Chert and dolomite in the Onondaga Limestone (Devonian) of New York State. Northeastern Geology 7(3-4): 136-143.

Shaver, R.H. 1985. Midwestern basin and arches region. Correlation of Stratigraphic Units of North America (COSUNA) Project. American Association of Petroleum Geologists.

Sparling, D.R. 1983. Conodont biostratigraphy and biofacies of lower Middle Devonian limestones, north-central Ohio. Journal of Paleontology 57(4): 825-864.

Sparling, D.R. 1988. Middle Devonian stratigraphy and conodont biostratigraphy, northcentral Ohio. Ohio Journal of Science 88(1): 12-18.

St. Jean, J. 1983. Stromatoporoid biostratigraphy; a case history. American Association of Petroleum Geologists Bulletin 67(3): 552-553.

St. Jean, J. 1986. Lower Middle Devonian Stromatoporoidea from Empire Beach, southern Ontario, Canada. Journal of Paleontology 60(6): 1147-1158.

Stauffer, C.R. 1957. The Columbus Limestone. Journal of Geology 65(4): 376-383.

Stewart, G.A. 1938. Middle Devonian corals of Ohio. Geological Society of America Special Paper 8. 120 pages.

Stukalina, G.A. 1988. Position of the lower/middle Devonian boundary from the viewpoint of crinoid evolution. In: McMillan, N.J., A.F. Embry, and D.J. Glass. Devonian of the World, vol. III: Paleontology, Paleoecology and Biostratigraphy. Canadian Society of Petroleum Geologists, Calgary, AB. pp. 131-136.

Swain, F.M. and M.A. Rogers. 1966. Stratigraphic distribution of carbohydrate residues in Middle Devonian Onondaga beds of Pennsylvania and western New York Geochimica et Cosmochimica Acta 30(5): 497-509.

Swartz, F.M. and F.M. Swain. 1941. Ostracodes of the Middle Devonian Onondaga beds of central Pennsylvania. Geological Society of America Bulletin 52(3): 381-457.

Taylor, A.E. and M.J. Camp. 1986. A biostratigraphic investigation of the Columbus Limestone at Marblehead, Ohio. Ohio Journal of Science 86(2): 9.

Thomson, K.S. 1977. The pattern of diversification among fishes. In: Hallam, A. Patterns of evolution. Elsevier, Amsterdam. pp.377-404.

Thomson, K.S. 1980. The ecology of Devonian lobe-finned fishes. In: Panchen, A.L. The 
Terrestrial Environment and the Origin of Land Vertebrates. Academic Press, London. pp. 187-222.

Tillman, J.R. 1984. Ostracodes of the superfamilies Beyrichiacea and Drepanellacea from Middle Devonian rocks of central Ohio. Journal of Paleontology 58(1): 234-253.

Tillman, J.R. and S.E. Murphy. 1978. Ostracodes of the superfamily Hollinacea from Middle Devonian rocks of central Ohio. Journal of Paleontology 52(2): 411-439.

Van Tyne, A.M. 1996. Middle Devonian Onondaga Limestone Reef Play. In: Roen, J.B. and J.B. Walker, eds. The Atlas of Major Appalachian Gas Plays. pp. 100-102.

Warters, H.R. 1972. Pinnacle reefs of Middle Devonian Onondaga Limestone, upstate New York and northern Pennsylvania. American Association of Petroleum Geologists Bulletin 56(3): 660.

Wells, J.W. 1944. Middle Devonian bone beds of Ohio. Geological Society of America Bulletin, 55: 273-302.

Wells, J.W. 1947. Provisional paleoecological analysis of the Devonian rocks of the Columbus Region. Ohio Journal of Science 47(3):119-126.

Wells, J.W. 1957. Coral Reefs. Treatise on Marine Ecology and Paleoecology, Geological Society of America Memoir 67(1): 609-631.

Westgate, L.G. and R.P. Fischer. 1933. Bone beds and crinoidal sands of the Delaware Limestone of central Ohio. Geological Society of America Bulletin 44: 1161-117.

Wheeler, A. 1975. Fishes of the World. Macmillan Publishing, New York. 366 pages.

Wicander, R. and R.P. Wright. 1983. Organic-walled microphytoplankton abundance and stratigraphic distribution from the Middle Devonian Columbus and Delaware Limestone of the Hamilton Quarry, Marion County, Ohio. Ohio Journal of Science 83(1): 2-13.

Willard, B. 1936. The Onondaga Formation in Pennsylvania. Journal of Geology 44(5): 578-603.

Williams, J.W. 1995. Factors controlling the formation of fossiliferous beds in the Devonian Columbus Limestone at Marblehead Quarry, Marblehead, Ohio. The Ohio Journal of Science 95(5): 325-330

Williams, L.A. 1980. Community succession in a Devonian patch reef (Onondaga Formation, New York); physical and biotic controls. Journal of Sedimentary Petrology 50(4): 1169-1185.

Wolosz, T.H. 1982. A model for faunal succession and reef growth in Edgecliff bioherms (Middle Devonian Onondaga Formation). American Association of Petroleum Geologists Bulletin 66(8): 1176-1177.

Wolosz, T.H. 1995a. A Middle Devonian temperate water limestone; isotopes, stromatoporoids and shallow water facies. American Association of Petroleum Geologists Bulletin 79(9): 1420.

Wolosz, T.H. 1995b. Edgecliff bioherms; patterns distribution and basinal controls. American Association of Petroleum Geologists Bulletin 79(9): 1420

Wolosz, T.H. 1991. Edgecliff reefs; Devonian temperate water carbonate deposition. American Association of Petroleum Geologists Bulletin 75(3): 696.

Wolosz, T.H. 1992. Patterns of reef growth in the Middle Devonian Edgecliff Member of the Onondaga Formation of New York and Ontario, Canada, and their ecological significance. Journal of Paleontology 66(1): 8-15.

Wolosz, T.H. and D.E. Paquette. 1988. Middle Devonian reefs of the Edgecliff Member of 
the Onondaga Formation of New York. In: McMillan, N.J., A.F. Embry, and D.J. Glass. Devonian of the World, vol. III: Paleontology, Paleoecology and Biostratigraphy. Canadian Society of Petroleum Geologists, Calgary, AB. pp. 531539.

Woodward, H.P. and P.H. Price. 1943. Devonian system of West Virginia. West Virginia Geological Survey vol. 15. Morgantown, WV. 654 pages.

Zangerl, R. 1981. Chondrichthyes I. In: Schultze, H.P. ed. Handbook of Paleoichthyology vol. 3a. Gustav Fischer Verlag, Stuttgart. 115 pages.

Zenger, D.H. 1967. Coloration of the 'Pink Chonetes" (brachiopod) of the Onondaga Limestone New York. Journal of Paleontology 41(1): 161-166. 
Table 1: Onondaga biozones of Oliver (1954) and Feldman (1985) in western New York germane to this study. $(E)=E d g e c l i f f$ Member, $(N)=N e d r o w$ Member, $(\mathrm{M})=$ Moorehouse Member and $(\mathrm{S})=$ Seneca Member.

\section{Oliver}

\section{Zone G-(M)}

Brachiopod facies

Aulopora sp.

Ceratopora sp.

Amplexiphyllum hamiltonae

Heterophrentis sp. A

H. sp. B

H. sp. C

Heliophyllum sp. A

Synaplophyllum sp. A

Bryozoa spp.

Fenestrella sp.

Lingula desiderata

L. $s p$.

"Discina" minuta

Pentamerella arata

Camarotoechia billingsi

C. tethys

Atrypa reticularis

A. spinosa

Coelospira camilla

Anoplotheca acutiplicata

Elytha fimbriata

Fimbrispirifer bivaricata

"Spirifer" duodenarius

" $S$ ". raricosta

Ambocoelia umbonata

Nucleospira concinna

Meristella doris

M. nasuta
M. sp.

Pentagonia unisulcata

Athyris spiriferoides

Megastrophia concava

Cymostrophia patersoni

Stropheodonta demissa

S. inequiradiata

Leptostrophia perplana

Pholidostrophia nacrea

Leptaena rhomboidalis

Schuchertella pandora

Chonetes deflectus

C. mucronatus

Productella navicella

Strophalosia? sp.

Levenia lenticularis

Rhipidomella sp.

Isorthis propinqua

Centronella glansfagea

Cypricardella sp. A

Euomphalus cf. clymenoides

Platyostoma lineata

P. turbinata

Styliolina fissurella

Goldringia trivolvis

breviconic cephalopod

Echinolichas eriopis

Phacops cristata

Odontocephalus selenurus

ostracods 
Table 1: cont.

\section{Coral facies (M)}

Arachnocrinus bulbosus

Favosites basalticus

$F$. canadensis

F. emmonsi

F. turbinatus

Coenites sp.

Syringipora sp.

Amplexiphyllum hamiltoniae

Heterophrentis prolifica

H. sp. A

H. sp. $B$

Siphonophrentis gigantea

Breviphrentis yandelli

Bethanyphyllum robustum

Blothrophyllum promissum

Heliophyllum sp. A

Cylindrophyllum elongatum

Synaptophyllum simcoense

Cystiphylloides americanum

C. sulcatum

Bryozoa spp.

Camarotoechia tethys

Pentamerella arata

Atrypa reticularis

A. spinosa

Coelospira camilla

Paraspirifer acuminatus

Elytha fimbriata

"Spirifer" duodenarius
"S". grieri

"S". macer

"S". raricosta

"S". varicosa

Meristella doris

M. nasuta

M. sp.

Athyris spiriferoides

Pentagonia unisulcata

Megastrophia concava

$M$. hemisphaerica

Stropheodonta demissa

S. inequiradiata

Leptostrophia perplana

Pholidostrophia nacrea

Leptaena rhomboidalis

Schuchertella pandora

Chonetes deflectus

C. mucronatus

Productella navicella

Levenia lenticularis

Isorthis propinqua

Amphigenia elongata

"Pleurotomaria" delicatula

"P". sp.

Euomphalus decewi

"Orthoceras" sp.

Goldringia trivolvis

Phacops cristata

Odontocephalus selenurus 
Table 1: cont.

\section{Zone I (S)}

Heterophrentis sp. $B$

Lingula sp.

Pentamerella arata

Camarotoechia tethys

Atrypa reticularis

A. spinosa

Coelospira camilla

Anoplotheca acutiplicata

"Spirifer" duodenarius

Pentagonia unisulcata

Athyris spiriferoides

Leptostrophia perplana

Leptaena rhomboidalis

Schuchertella pandora

Chonetes deflectus

C. mucronatus

Levenia lenticularis

Isorthis propinqua

Coleolus crenatocinctum

\section{Zone J (S)}

Pink Chonetes

Camarotoechia tethys

Atrypa reticularis

A. spinosa

Coelospira camilla

Anoplotheca acutiplicata

Elytha fimbriata

"Spirifer" duodenarius

Meristella nasuta
Pentagonia unisulcata

Athyris spiriferoides

Schuchertella pandora

Chonetes lineatus

C. mucronatus

Levenia lenticularis

Odontocephalus selenurus

Zone K (S)

Western facies

Ceratopora sp.

Lingula sp.

Camarotoechia tethys

Atrypa reticularis

A. spinosa

Coelospira camilla

Meristella doris

Stropheodonta demissa

S. inequiradiata

Leptaena rhomboidalis

Chonostrophia reversa

Chonetes mucronatus

Levenia lenticularis

Platyostoma lineata

Platyceras carinatum

Odontocephalus selenurus

Pentamerella arata

Romingeria $s p$. 
Table 1: cont.

Feldman

Atrypa-Megakozlowskiella (E-M)

Atrypa reticularis

Megakozlowskiella raricosta

Schizophoria cf. multistriata

Pentagonia unisulcata

Orthotetacids indet.

Lavenea sp. A

Pentamerella arata

Leptaena aff. 'rhomboidalis'

Nucleospira aff. ventricosa

Stropheodonta cf. demissa

Dalejina sp. A

Athyris sp. A

Megastrophia sp.

Coelospira camilla

'Mucrospirifer' sp.

Acrospirifer duodenaria

Chonetes sp.

Cyrtina hamiltonensis

Elytha fimbriata

Gypidula sp.

Pacificocoelia acutiplicata

Rhipidomella?

Aulopora

Favosites

Amplexiphyllum

Heterophrentis

Acinophyllum

Breviphrentis

cf. Syringaxon

\section{Atrypa-Levenea (M)}

Atrypa reticularis

Lavenea sp. A

Pentagonia unisulcata

Megakozlowskiella raricosta

Coelospira camilla

Orthotetacids indet.

Nucleospira aff. ventricosa

Dalejina sp. A

Leptaena aff. 'rhomboidalis'

Megastrophia sp.

Cupularostrum sp. A

Athyris sp. A

Schizophoria cf. multistriata

Stropheonella cf. punctulifera

Gypidula sp.

Pentamerella arata

Cyrtina hamiltonensis

Elytha fimbriata

Favosites

Aulopora

Acinophyllum

Heliophyllum

cf. Amplexiphullum

Breviphrentis

'Heterophrentis'

cf. Syringaxon

\section{Leptaena-Megakozlowskiella}

(N-M)

Leptaena aff. rhomboidalis

Megakozlowski raricosta 
Table 1: cont.

Pacificocoelia acutiplicata

Orthotetacids indet

Atrypa 'reticularis'

Pentamerella arata

Megastrophia so.

Athyris sp. A

Dalejina sp. A

Levenea sp. A

Coelospira camilla

Gypidula sp.

Meristina cf. nasuta

stropheodontids indet

Stropheodonta cf. demissa

Trematospira sp.

Charionoides aff. doris

Syringipora

Aulopora

Favosites

Amplexiphyllum

'Heterophrentis'

Acinophyllum

Straparollus

Liospira?

Ecculiomphalus

Foordites

Phacops cristata

Odontocephalus

cf. Dechenella

Dalmanitid frags

Camarate columnals

\section{Atrypa-Coelospira-Nucleospira}

(M)

Atrypa reticularis

Coelospira camilla

Nucleospira aff. ventricosa

Acrospirifer duodenaria

Megakozlowski raricosta

Pentagonia unisulcata

Cupulorostrum sp. A

Schizophoria cf. multistriata

Dalejina sp. A

Pentamerella arata

'Mucrospirifer'sp.

Cyrtina hamiltonensis

Elytha fimbriata

Athyris sp. A

orthotetacids indet.

stropheodontids indet

Ambocoelia sp.

Cupulorostrum sp. B

Megastrophia sp.

Stropheodonta cf. demissa

athyridaceans indet.

Athyris sp. A

eospiriferid? Iindet.

Lavenea sp. A

Schuchertella sp.

Atribonium halli

Cyrtina sp. A

Dalejina sp. $B$

Leptaena aff. 'rhomboidalis' 
Table 1: cont.

Meristina cf. nasuta

Rhipidomella?

Rhychospirina sp.

Chonetes

'Chonetes' aff. lincata

Megakozlowski raricosta

Leptaena aff. 'rhomboidalis'

Megastrophia sp.

orthotetacids indet.

Athyris sp. A

Atrypa 'reticularis'

Pentamerella arata

Heterophrentis?

Amplexiphyllum?

Euomphalacean frags

Phacops cristata

Odontocephalus

camarate columnals 
Table 2: Thin sections taken from various locations through the Columbus and Onondaga Limestones.

\begin{tabular}{|c|c|}
\hline Number & $\begin{array}{l}\text { Formation } \\
\text { Columbus Limestone }\end{array}$ \\
\hline 1 & Lower Columbus-near the base \\
\hline 2 & Lower Columbus-coral zone \\
\hline 3 & Lower Columbus-a meter above coral layer \\
\hline 4 & Upper Columbus-fossil zone 4 meters above coral layer \\
\hline 5 & Upper Columbus- 6 meters above coral bed \\
\hline 6 & Upper Columbus-hash layer \\
\hline 7 & Upper Columbus-hash layer \\
\hline 8 & $\begin{array}{l}\text { Onondaga Formation } \\
\text { Edgecliff-quarry floor }\end{array}$ \\
\hline 9 & Clarence-near the base \\
\hline 10 & Clarence- 1 meter above base \\
\hline 11 & Clarence-at the base of the lighter zone \\
\hline 12 & Clarence- 1 meter into the lighter zone \\
\hline 13 & Clarence-coral layer \\
\hline 14 & Clarence-lighter zone above coral layer \\
\hline 15 & Moorehouse-darker zone transitional with the Clarence \\
\hline $16 \mathrm{~A}$ & Moorehouse- 2 meters above the Nedrow \\
\hline $16 \mathrm{~B}$ & Moorehouse- 2 meters above the Nedrow \\
\hline 17 & Moorehouse- 2 meters below the Tioga \\
\hline 18 & Seneca- 1 meter above Tioga \\
\hline
\end{tabular}


Table 2: cont.

Comments

very fine-grained, no fossils.

large corals.

similar to the basal unit, but a bit coarser.

grainstone with tentaculitids, bryozoans, crinoids, ostracods and brachiopods

packstone with bryozoans, brachiopods, ostracods and crinoids.

hash layer with crinoids, bryozoans, corals, tentaculitids, brachiopods and trilobites.

hash layer with crinoids, brachiopods, bryozoans, gastropods and tentaculitids.

grainstone with crinoids, trilobites, brachiopods, bryozoans and ostracods.

fine-grained with rare crinoids, trilobites and bryozoans.

similar to previous section, but with more fossils

including brachiopods and gastropods.

muddy, large crinoids and smaller bryozoan pieces, several encrusting algae.

packstone with crinoids, trilobites, brachiopods,

bryozoans, corals and ostracods.

infilled and recrystallized coral colony.

packstone with crinoids, trilobites, brachiopods,

bryozoans and tabulate corals.

very-fined grained, rare crinoids and a trilobite spine, but many ostracods.

grainstone with large crinoids, trilobites, brachiopods and bryozoans.

grainstone with large crinoids, trilobites, brachiopods and bryozoans.

grainstone with crinoids, trilobites, bryozoans and tentaculitids.

grainstone with trilobites, brachiopods and phosphatic material. 
Table 3: Specimens from the Buffalo Museum of Science that have been reassigned to a new taxon or identified by plate (bone) name. $\mathrm{AVL}=$ anterior ventrolateral plate, $\mathrm{AL}=$ anterior lateral plate, $\mathrm{IH}=$ interohyal. All Buffalo specimens begin with the letter, 'E'.

\begin{tabular}{|c|c|c|c|}
\hline Museum identification & Number & Plate & Reclassification or body part \\
\hline Acanthaspis & E18439 & & Macropetalichtys sullivanti \\
\hline Acanthaspis armata & E18062 & & Macropetalichtys sullivanti \\
\hline Acanthaspis armata & E18067 & & Macropetalichtys sullivanti \\
\hline Acanthaspis armata & E18430 & & Macropetalichtys sullivanti \\
\hline Acanthaspis armata & E17951 & & Macropetalichtys sullivanti \\
\hline Coccosteus & E22157 & & Unidentified \\
\hline Deinodus bennetti & E2451 & $12 \mathrm{~A}$ & Dorsal? spine \\
\hline Deinodus bennetti & E16635 & $11 \mathrm{~F}$ & Dental plate \\
\hline Deinodus bennetti & E16639 & $11 \mathrm{~A}, 11 \mathrm{~B}$ & Dental plate \\
\hline Deinodus bennetti & E16627 & 14B & Cranial plate \\
\hline Deinodus bennetti & E16651 & $12 \mathrm{~F}$ & Spine \\
\hline Deinodus bennetti & E16650 & $12 \mathrm{C}$ & Spine \\
\hline Deinodus bennetti & E16656 & & AL? \\
\hline Deinodus bennetti & E1860 & $11 \mathrm{C}$ & Dental plate \\
\hline Deinodus bennetti & E2467 & $10 \mathrm{C}$ & Spine \\
\hline Deinodus bennetti & E2471 & $11 \mathrm{D}$ & Dental plate \\
\hline Deinodus bennetti & E2465 & $12 \mathrm{D}$ & Spine \\
\hline Deinodus bennetti & E16646 & $10 \mathrm{E}, 10 \mathrm{~F}$ & Spine \\
\hline Deinodus bennetti & E16648 & $10 \mathrm{D}$ & Spine \\
\hline Deinodus bennetti & E16644 & 13 & Spine \\
\hline Deinodus bennetti & E2466 & $10 \mathrm{~B}$ & Spine \\
\hline Deinodus bennetti & E18582 & $10 \mathrm{~A}$ & Spine and AVL \\
\hline Deinodus bennetti & E16654 & $14 \mathrm{~A}$ & Unidentified \\
\hline Dinichthys & E18429 & & Unidentified \\
\hline Machaeracanthus peracutus & E18318 & & Machaeracanthus major \\
\hline Machaeracanthus peracutus & E1854 & & Machaeracanthus major \\
\hline
\end{tabular}


Table 3: cont.

\begin{tabular}{|c|c|c|c|}
\hline Museum identification & Number & Plate & Reclassification or body part \\
\hline Machaeracanthus sullivanti & E22335 & & Machaeracanthus major \\
\hline Machaeracanthus major & E1847 & & Machaeracanthus major \\
\hline Machaeracanthus major & E6855 & & Machaeracanthus major \\
\hline Machaeracanthus major & E17941 & & Machaeracanthus major \\
\hline Machaeracanthus peracutus & E18448 & & Machaeracanthus major \\
\hline Machaeracanthus peracutus & E2650 & & Machaeracanthus major \\
\hline Machaeracanthus peracutus & E1853 & & Machaeracanthus major \\
\hline Machaeracanthus peracutus & E1851 & & Machaeracanthus major \\
\hline Machaeracanthus peracutus & E1850 & & Machaeracanthus major \\
\hline Macropetalichtys rapheidolabis & E17945 & & Ptyctodus; dental plate \\
\hline Paleomylus frangens & E7765 & $7 \mathrm{~A}$ & Dental plate \\
\hline Paraptyctodus reimanni & E12203 & 6 & Ptyctodus reimanni \\
\hline Unidentified & E18087 & $25 \mathrm{C}$ & Deinodus bennetti; dental plate \\
\hline Unidentified & E18086 & $11 \mathrm{E}$ & Deinodus bennetti; dental plate \\
\hline Unidentified & $\mathrm{E} 22102$ & $24 \mathrm{~B}$ & Macropethalichthys; spine \\
\hline Unidentified & E22106 & $24 \mathrm{G}$ & Macropetalichthys \\
\hline Unidentified & E18095 & $25 \mathrm{D}$ & Deinodus bennetti \\
\hline Unidentified & E18102 & $25 \mathrm{E}$ & Deinodus bennetti \\
\hline Unidentified & E18106 & $25 \mathrm{~A}$ & Deinodus bennetti; spine \\
\hline Unidentified & E17940 & $24 \mathrm{E}$ & Ptyctodus dental plate \\
\hline Unidentified & $\mathrm{E} 18440$ & $24 \mathrm{D}$ & Onychodus; tooth \\
\hline Unidentified & E18223 & $24 \mathrm{~F}$ & Palaeomylus; dental plate \\
\hline Unidentified & E18115 & $24 \mathrm{C}$ & Macropethalichthys; spine \\
\hline Unidentified & E18094 & $24 \mathrm{~A}$ & Deinodus bennetti?; AL? \\
\hline Unidentified & E18112 & $25 \mathrm{~B}$ & Deinodus bennetti; AVL \\
\hline Unidentified & E18389 & $25 \mathrm{~F}$ & Deinodus bennetti?; IH? \\
\hline
\end{tabular}


Table 3: cont.

244 specimens were examined.

in Cleveland

163 specimens were examined in Buffalo.

41 taxa was reduced to 9 valid taxa. 
Table 4: Specimens of the Cleveland Museum of Natural History that have been assigned to a new taxon or identified by plate name. $\mathrm{AVL}=$ anterior ventrolateral plate, $\mathrm{AL}=$ anterior lateral plate, $\mathrm{IH}=$ interohyal. Specimens with the prefix, "BW" were from the Baldwin College Collection, those with the prefix, "OC" were from the Oberlin College

Collection and the one with the prefix, "PF" was from the Field Museum in Chicago.

\begin{tabular}{|c|c|c|c|}
\hline Museum identification & Number & Plate & Reclassification or body part \\
\hline Acanthaspis & BW-3-412 & $21 \mathrm{~J}$ & Macropetalichtys sullivanti \\
\hline Acanthaspis & BW-3-363 & & Macropetalichtys sullivanti \\
\hline Acanthaspis & BW-3-517 & & Macropetalichtys sullivanti \\
\hline Acanthaspis & BW-3-80 & & Macropetalichtys sullivanti \\
\hline Acanthaspis & BW-3-397 & & Macropetalichtys sullivanti \\
\hline Acanthaspis & $\mathrm{BW}-3-254$ & & Macropetalichtys sullivanti \\
\hline Acanthaspis & BW-3-337 & & Macropetalichtys sullivanti \\
\hline Acanthaspis & BW-3-1? & & Macropetalichtys sullivanti \\
\hline Acanthaspis & BW-3-83 & & Macropetalichtys sullivanti \\
\hline Acanthaspis & OC7903 & & Macropetalichtys sullivanti \\
\hline Acanthaspis & OC7899 & & Macropetalichtys sullivanti \\
\hline Acanthaspis & PF632FMNH & & Macropetalichtys sullivanti \\
\hline Acantholepis & BW-3-175 & & Macropetalichtys sullivanti \\
\hline Acantholepis & BW-3-246 & & Eczematolepis fragilis \\
\hline Acantholepis & BW-3-426 & & Eczematolepis fragilis \\
\hline Acantholepis & BW-3-239 & & Eczematolepis fragilis \\
\hline Acantholepis & BW-3-381 & & Eczematolepis fragilis \\
\hline Acantholepis & BW-3-175 & & Eczematolepis fragilis \\
\hline Acantholepis sustulosus & BW-3-459 & & Eczematolepis fragilis \\
\hline Acantholepis & BW-3-245 & & Eczematolepis fragilis \\
\hline Asperichthys linearius & BW-3-199 & $20 \mathrm{E}$ & Eczematolepis fragilis \\
\hline
\end{tabular}


Table 4: cont.

\begin{tabular}{|c|c|c|c|}
\hline Museum identification & Number & Plate & Reclassification or body part \\
\hline Asperichthys lineatus & BW-3-171 & $20 \mathrm{~A}$ & Ptyctodont spine \\
\hline Asterosteus & BW-3-113 & $18 \mathrm{~B}$ & Deinodus bennetti; AVL \\
\hline Asterosteus & BW-3-322 & 15 & Deinodus bennetti; cranium \\
\hline Asterosteus & BW-3-417 & $18 \mathrm{C}$ & Deinodus bennetti; cranium \\
\hline Asterosteus & BW-3-194 & $18 \mathrm{~A}$ & Deinodus bennetti; AVL \\
\hline Asterosteus & BW-3-103 & $18 \mathrm{D}$ & Deinodus bennetti; cranium \\
\hline Cavagnathus & BW-3-232 & $20 \mathrm{~F}$ & Ptyctodont AL \\
\hline Delphinodus (cf.) & BW-3-187 & $14 \mathrm{E}$ & Deinodus ohioensis? \\
\hline Asterosteus (cf.) & BW-3-376 & $18 \mathrm{E}$ & Macropetalichthys sullivanti; spine \\
\hline Onychodus (cf.) & BW-3-252 & $2 \mathrm{~B}$ & Opercle? \\
\hline Secansodus (cf.) & BW-3-111 & $20 \mathrm{C}$ & Ptyctodont spine \\
\hline Conodus & BW-3-185 & $16 \mathrm{C}$ & Deinodus ohioensis \\
\hline Conodus & BW-3-150 & $16 \mathrm{~A}$ & Deinodus ohioensis \\
\hline Conodus & BW-3-405 & $16 \mathrm{D}$ & Deinodus ohioensis \\
\hline Conodus & BW-3-117 & $16 \mathrm{~F}$ & Deinodus ohioensis \\
\hline Conodus & BW-3-168 & $16 \mathrm{E}$ & Deinodus ohioensis \\
\hline Coultraotus delicatus & BW-3-206 & $20 \mathrm{G}$ & Ptyctodus; dental plate \\
\hline Delphinodus acutus & BW-3-151 & $14 \mathrm{D}$ & Deinodus ohioensis? \\
\hline Delphinodus elegans & BW-3-191 & $14 \mathrm{C}$ & Deinodus ohioensis? \\
\hline Onychodus & BW-3-362 & $1 \mathrm{C}$ & Parietal \\
\hline Onychodus & BW-3-184 & $2 \mathrm{C}$ & Opercle? \\
\hline Onychodus & BW-3-410 & $1 \mathrm{~B}$ & Parietal \\
\hline Onychodus (cf) & BW-3-276 & $2 \mathrm{~A}$ & Opercle? \\
\hline Onychodus sigmoides & BW-3-359 & & Unidentified \\
\hline Ptyctodus curtus & BW-3-448 & & Unidentified \\
\hline
\end{tabular}


Table 4: cont.

\begin{tabular}{llll} 
Museum identification & Number & Plate & Reclassification or body part \\
\hline Pulsodus & BW-3-183 & 14G & Deinodus ohioensis? \\
Pulsodus & BW-3-107 & 14F & Deinodus ohioensis? \\
Rhynchodus & BW-3-210 & 9F & Deinodus? \\
Rhynchodus longatus & BW-3-195 & 9E & Palaeomylus? dental plate \\
Rhynchodus minor & BW-3-144 & 9C & Ptyctodont dental plate \\
Rhynchodus minor & BW-3-179 & 9B & Deinodus ohioensis?; dental plate \\
Rhynchodus tenius & BW-3-84 & 9D & Ptyctodont AL \\
Secansodus & BW-3-422 & & Ptyctodont spine \\
Secansodus & BW-3-167 & & Ptyctodont spine \\
Secansodus & BW-3-424 & & Ptyctodont spine \\
Secansodus & BW-3-96 & 20K & Ptyctodus; dental plate \\
Secansodus & BW-3-328 & 20J & Ptyctodus; dental plate \\
Secansodus & BW-3-190 & & Ptyctodont spine \\
Secansodus & BW-3-260 & & Ptyctodont spine \\
Secansodus & BW-3-465 & & Ptyctodont spine \\
Secansodus & BW-3-469 & & Ptyctodont spine \\
Secansodus & BW-3-342 & 20I & Rhynchodus; dental plate \\
Unidentified & BW-3-474 & 21A & Rhynchodus; dental plate \\
Unidentified & BW-3-366 & 21C & Machaeracanthus; spine \\
Unidentified & BW-3-452 & 3B & cf. Onychodus \\
Unidentified & BW-3-345 & 23B & Ptyctodont marginal \\
& & & \\
\hline SW & & &
\end{tabular}


Table 4: cont.

\begin{tabular}{|c|c|c|c|}
\hline Museum identification & Number & Plate & Reclassification or body part \\
\hline Unidentified & BW-3-360a & $23 \mathrm{~F}$ & Ptyctodont marginal \\
\hline Unidentified & BW-3-372 & $3 \mathrm{~A}$ & Onychodus sigmoides; subopercle \\
\hline Unidentified & BW-3-390 & $21 \mathrm{G}$ & Macropetalichthys; spine and AVL \\
\hline Unidentified & BW-3-504 & $8 \mathrm{C}$ & Rhynchodus secans \\
\hline Unidentified & BW-3-418 & $8 B$ & Rhynchodus secans \\
\hline Unidentified & $\mathrm{BW}-3-31$ & $21 \mathrm{~B}$ & Rhynchodus secans; dental plate \\
\hline Onychodus & BW-3-498 & $3 \mathrm{D}$ & Ptyctodont \\
\hline Unidentified & BW-3-325 & $2 \mathrm{D}$ & "cf Onychodus" cliethrum?, \\
\hline Unidentified & BW-3-240 & $22 \mathrm{C}$ & Deinodus? \\
\hline Unidentified & BW-3-447 & $22 \mathrm{~B}$ & Deinodus? \\
\hline Unidentified & BW-3-377 & $23 \mathrm{~A}$ & Ptyctodont marginal \\
\hline Unidentified & BW-3-376 & $18 \mathrm{E}$ & Macropetalichthys; spine \\
\hline Unidentified & BW-3-468b & $22 \mathrm{D}$ & Deinodus bennetti; dorsal? spine \\
\hline Unidentified & BW-3-364 & $8 \mathrm{E}$ & Rhynchodus secans \\
\hline Unidentified & BW-3-343 & & Machaeracanthus spine \\
\hline Unidentified & BW-3-355 & $23 \mathrm{D}$ & Ptyctodont marginal \\
\hline Unidentified & BW-3-454 & $21 \mathrm{H}$ & Macropetalichthys; spine and AVL \\
\hline Unidentified & BW-3-468a & $22 \mathrm{~A}$ & Deinodus? \\
\hline Unidentified & BW-3-451 & $23 \mathrm{E}$ & Ptyctodont marginal \\
\hline Unidentified & BW-3-466 & $8 \mathrm{~F}$ & Rhynchodus secans \\
\hline Unidentified & BW-3-462 & $3 \mathrm{C}$ & cf Onychodus \\
\hline Unidentified & BW-3-453 & $23 \mathrm{C}$ & Ptyctodont marginal \\
\hline Unidentified & BW-3-456 & $21 \mathrm{I}$ & Macropetalichthys?; spine and AVL \\
\hline Unidentified & BW-3-368 & $2 \mathrm{E}$ & Onychodus (cf.); shoulder girdle? \\
\hline Unidentified & BW-3-361 & $2 \mathrm{~F}$ & Onychodus (cf.); shoulder girdle? \\
\hline Unidentified & BW-3-95 & 19D & Acanthodian tooth spiral \\
\hline
\end{tabular}


Table 5: A list of valid specimens, including those taxa that have been reclassified. The taxa are placed in alphabetical order for easy reference. Specimens are from the collections of the Buffalo Science Museum and the Cleveland Museum of Natural History and combined into a single, comprehensive list.

\begin{tabular}{|c|c|c|}
\hline Genus & Comments & Valid Genus \\
\hline Acanthaspis armata & & Macropetalichthys sullivanti \\
\hline Acantholepis & & Eczematolepis fragilis \\
\hline Agassichthys & & Macropetalichthys sullivanti \\
\hline Asperichthys & genus not valid & various \\
\hline Asterolepis & not valid in collections & \\
\hline Asterosteus & not valid in collections & \\
\hline Aulacosteus & & Ptyctodus reimanni \\
\hline Bilobodus & genus not valid & various \\
\hline Casnodus & & Deinodus bennetti \\
\hline Cavagnathus & genus not valid & various \\
\hline Chirodipterus & not valid in collections & \\
\hline Coccosteus & not valid in collections & \\
\hline Conodus & not valid in collections & Deinodus ohioensis \\
\hline Cosmodus & & Deinodus bennetti \\
\hline Coultraotus delicatus & genus not valid & various \\
\hline Cyrthacanthus & genus not valid & various \\
\hline Delphinodus & genus not valid & various \\
\hline Dentichthys & genus not valid & various \\
\hline Dinacanthodes & & Machaeracanthus major \\
\hline Dinichthys & not valid in collections & \\
\hline Dinomylostoma & not valid in collections & \\
\hline Gyrtacanthus & genus not valid & various \\
\hline
\end{tabular}


Table 5: cont.

\begin{tabular}{|c|c|c|}
\hline \multirow{2}{*}{\multicolumn{2}{|c|}{$\frac{\text { Genus }}{\text { Heintzaspis }}$}} & Valid Genus \\
\hline & & Macropetalichthys sullivanti \\
\hline \multicolumn{2}{|c|}{ Machaeracanthus peracutus } & Machaeracanthus major \\
\hline \multicolumn{2}{|l|}{ Machaerius } & Machaeracanthus major \\
\hline \multicolumn{2}{|c|}{ Macropetalichthys rapheidolabis } & Macropetalichthys sullivanti \\
\hline \multicolumn{2}{|l|}{ Ohiodorulites } & Macropetalichthys sullivanti \\
\hline \multicolumn{2}{|l|}{ Oracanthus abbreviatus } & Eczematolepis fragilis \\
\hline \multicolumn{2}{|l|}{ Oracanthus granulatus } & Eczematolepis fragilis \\
\hline Palaeomylus crassus & not found in collections & Palaeomylus crassus \\
\hline \multicolumn{2}{|l|}{ Palaeomylus frangens } & Palaeomylus frangens \\
\hline \multicolumn{2}{|l|}{ Paraptyctodus reimanni } & Ptyctodus reimanni \\
\hline \multicolumn{2}{|l|}{ Phlyctaenacanthus } & Eczematolepis fragilis \\
\hline \multicolumn{2}{|l|}{ Physichthys } & Macropetalichthys sullivanti \\
\hline Platoditus & genus not valid & various \\
\hline Platygnathus & not valid in collections & \\
\hline Pulsodus & genus not valid & various \\
\hline Ramphodus & & Rhynchodus secans \\
\hline Rhamphodontus & & Rhynchodus secans \\
\hline Rhamphodopsis & not found in collections & Rhynchodus secans \\
\hline Rhamphodus & & Rhynchodus secans \\
\hline Rhychodontus & & Rhynchodus secans \\
\hline Rhychosteus & & Rhynchodus secans \\
\hline Rhynchodus elegatus & species not valid & Rhynchodus secans \\
\hline Rhynchodus longatus & species not valid & Rhynchodus secans \\
\hline Rhynchodus minor & species not valid & Rhynchodus secans \\
\hline Rhynchodus pygmaeus & species not valid & Rhynchodus secans \\
\hline Rhynchodus tenius & species not valid & Rhynchodus secans \\
\hline Rhynchognathus & & Rhynchodus secans \\
\hline Ringinia & & Rhynchodus secans \\
\hline Rinodus & & Ptyctodus reimanni \\
\hline Secansodus & genus not valid & various \\
\hline Stenoichthys & genus not valid & various \\
\hline Tanaodus & genus not valid & various \\
\hline
\end{tabular}


Table 6: The occurrence of fish taxa and their trophic modes within the members of the Onondaga,

Columbus and

Delaware limestones.

\begin{tabular}{|c|c|c|c|c|c|}
\hline & Lower Moorehouse & Upper Moorehouse & Seneca & Columbus & Delaware \\
\hline Deinodus bennetti-durophagy? & & $\mathrm{x}$ & & $\mathrm{x}$ & \\
\hline Deinodus ohioensis-durophagy? & & & & $\mathrm{x}$ & \\
\hline Eczematolepis-? & & & & $\mathrm{x}$ & $\mathrm{x}$ \\
\hline Machaeracanthus-piscivore & $\mathrm{x}$ & $\mathrm{x}$ & $\mathrm{x}$ & $\mathrm{x}$ & $\mathrm{x}$ \\
\hline Macropetalichthys-? & $\mathrm{x}$ & $\mathrm{x}$ & $\mathrm{x}$ & $\mathrm{x}$ & $\mathrm{x}$ \\
\hline Onychodus-predator & & $\mathrm{x}$ & & & $\mathrm{x}$ \\
\hline Palaeomylus-durophagy & & $\mathrm{x}$ & & $\mathrm{x}$ & $\mathrm{x}$ \\
\hline Ptyctodus-durophagy & & $\mathrm{x}$ & & & \\
\hline Rhynchodus-predator & & $\mathrm{x}$ & & $\mathrm{x}$ & $\mathrm{x}$ \\
\hline
\end{tabular}




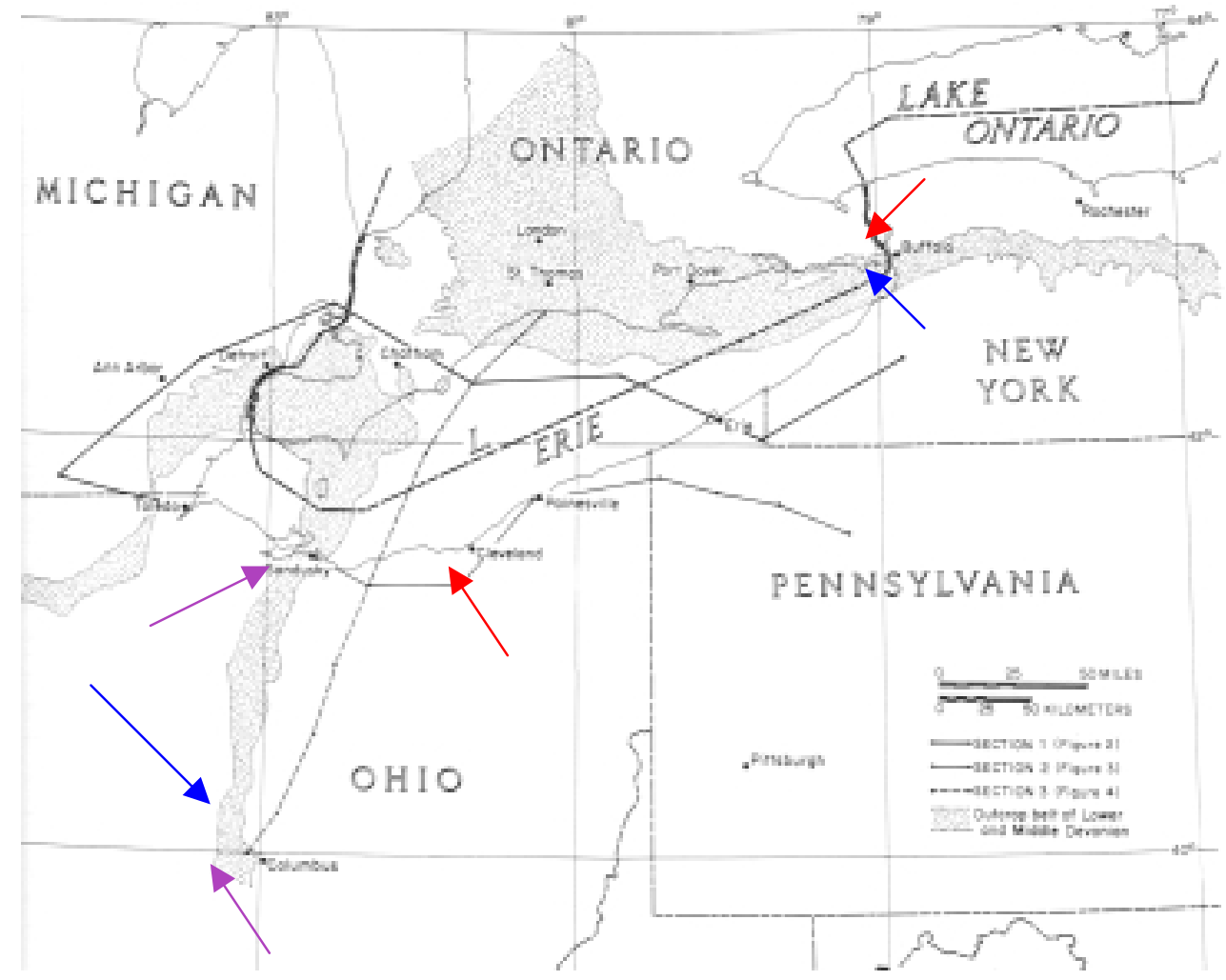

Figure 1A: Outcrop belt of the Eifelian in New York and Ohio (Rickard, 1984). Blue arrows indicate primary study sites, and red arrows indicate museum locations. The purple arrows indicate the secondary sites in Columbus and Sandusky, Ohio.

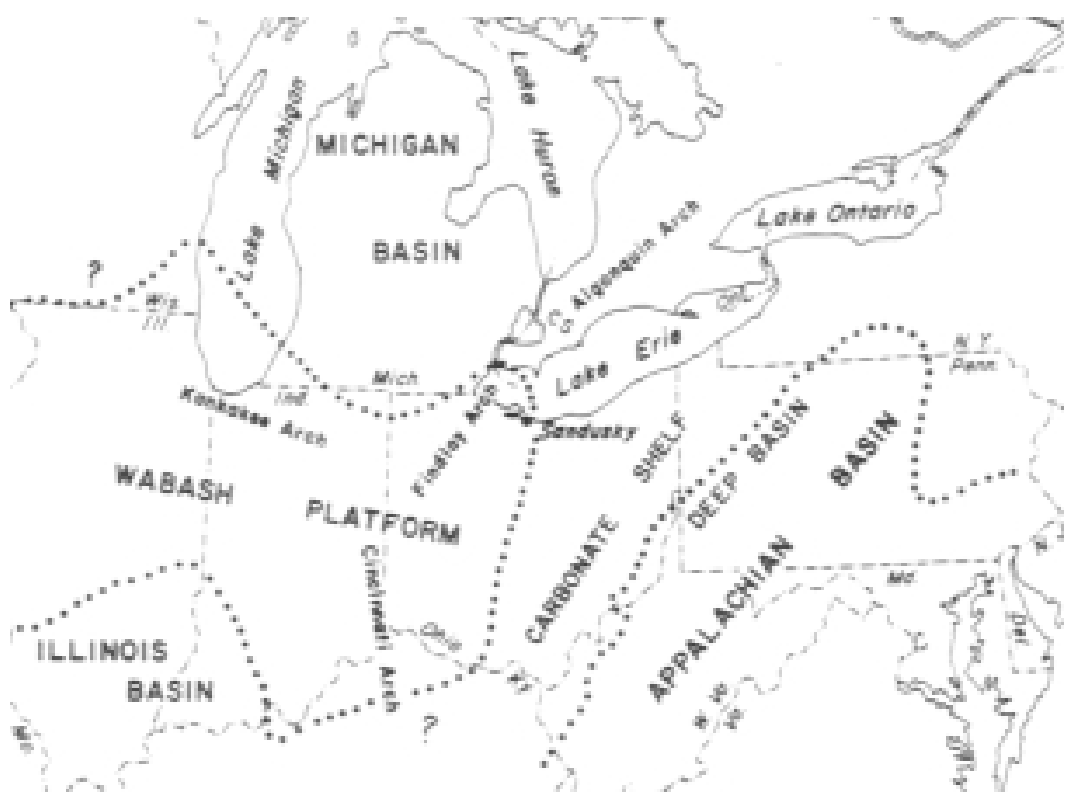

Figure 1B: Paleoenvironments of the Eifelian (Sparling, 1988). 


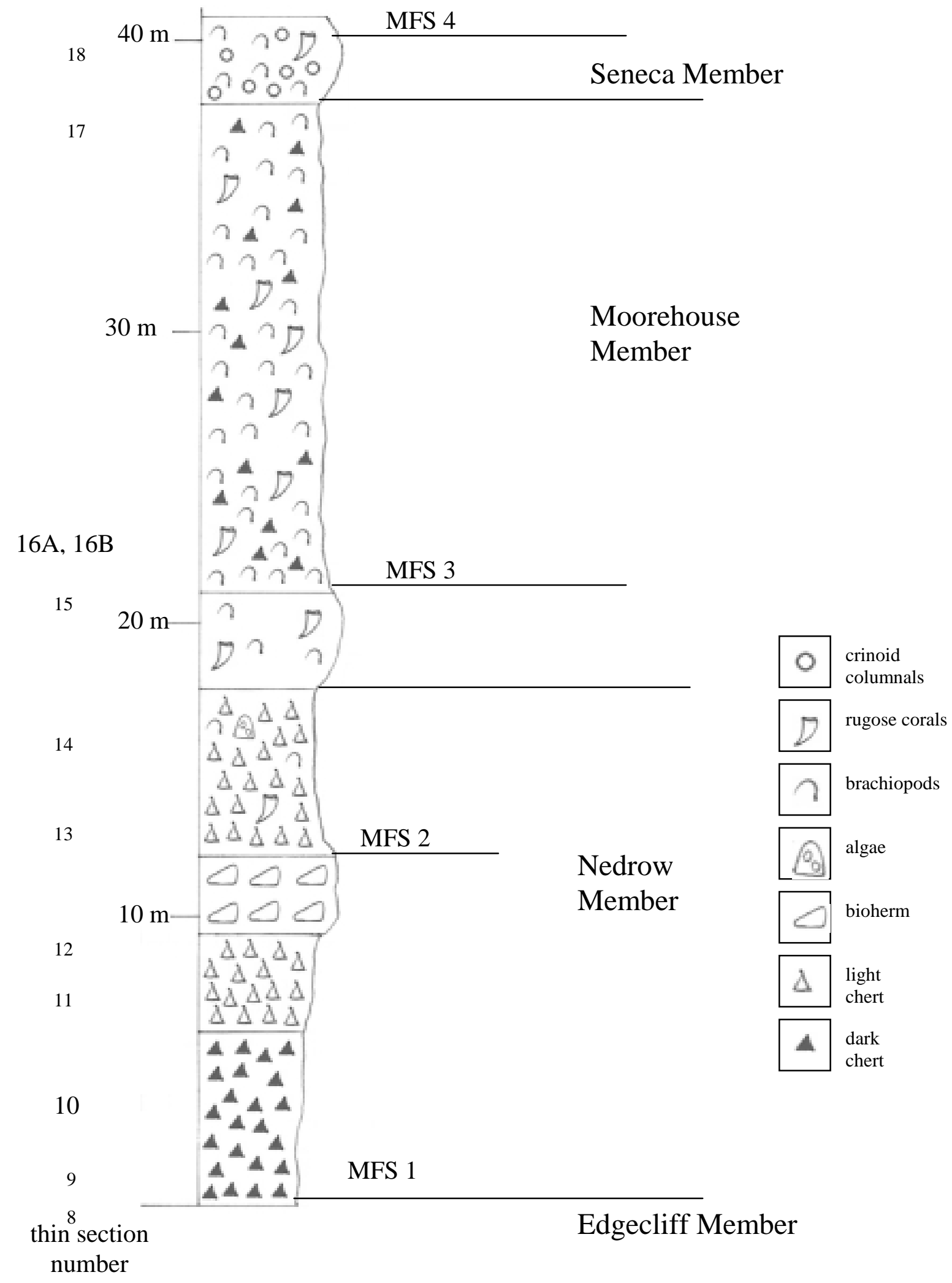

Figure 2: Stratigraphic section of the Onondaga Formation at the Cheektowaga Quarry near Buffalo, New York. The four members are show as they appear at the quarry. Maximum flooding surfaces are designated by 'MFS'. Thin section numbers are provided to the left of the column. 


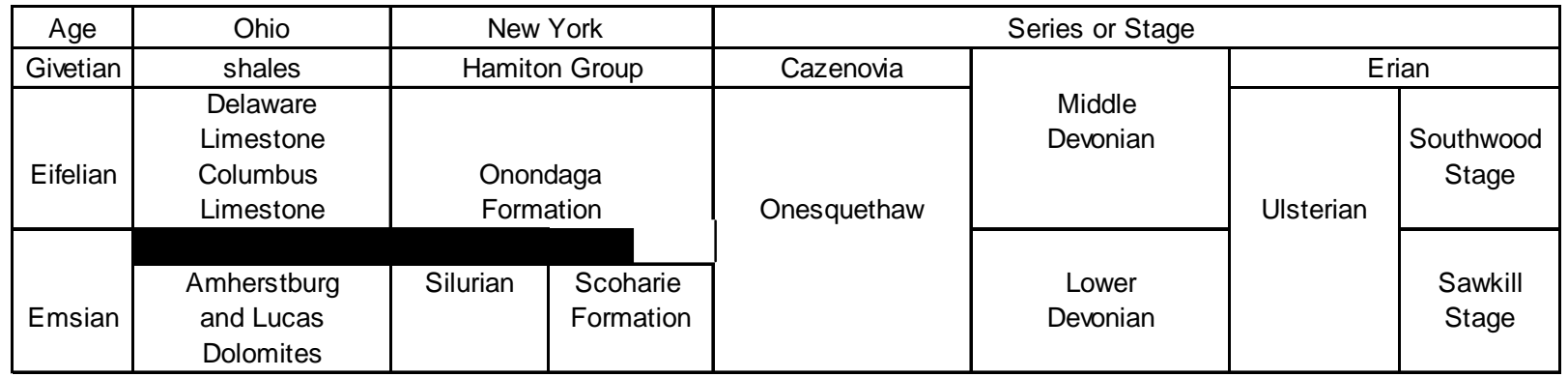

Figure 3A: Time divisions proposed for the Eifelian. Dark areas represent unconformities.
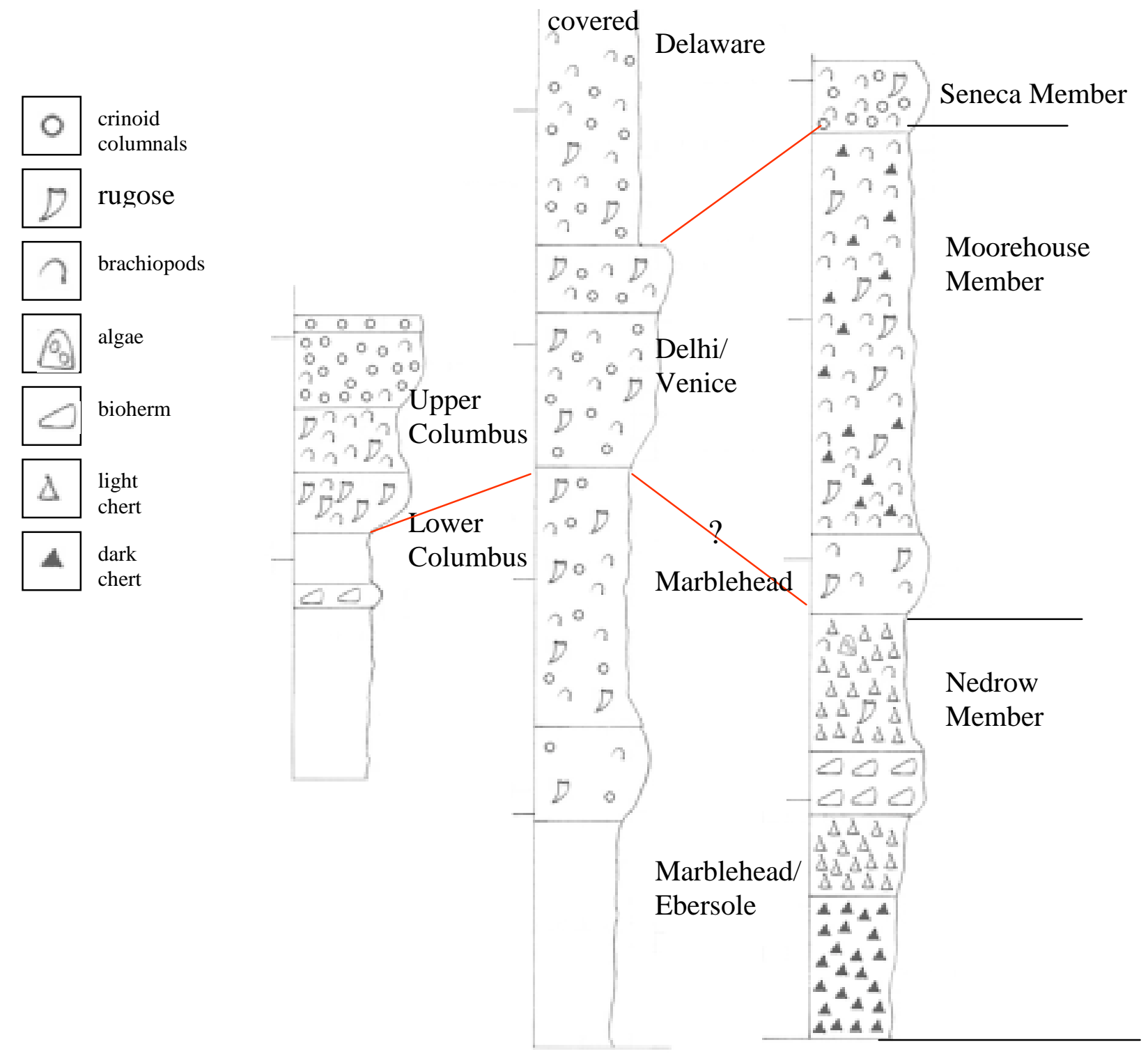

Figure 3B: Correlation chart of the Columbus and Delaware Limestones in Ohio and the Onondaga Formation in western New York. From left to right, the columns represent sections from Warrensburg, Ohio, Sandusky, Ohio and Cheektowaga, New York. 

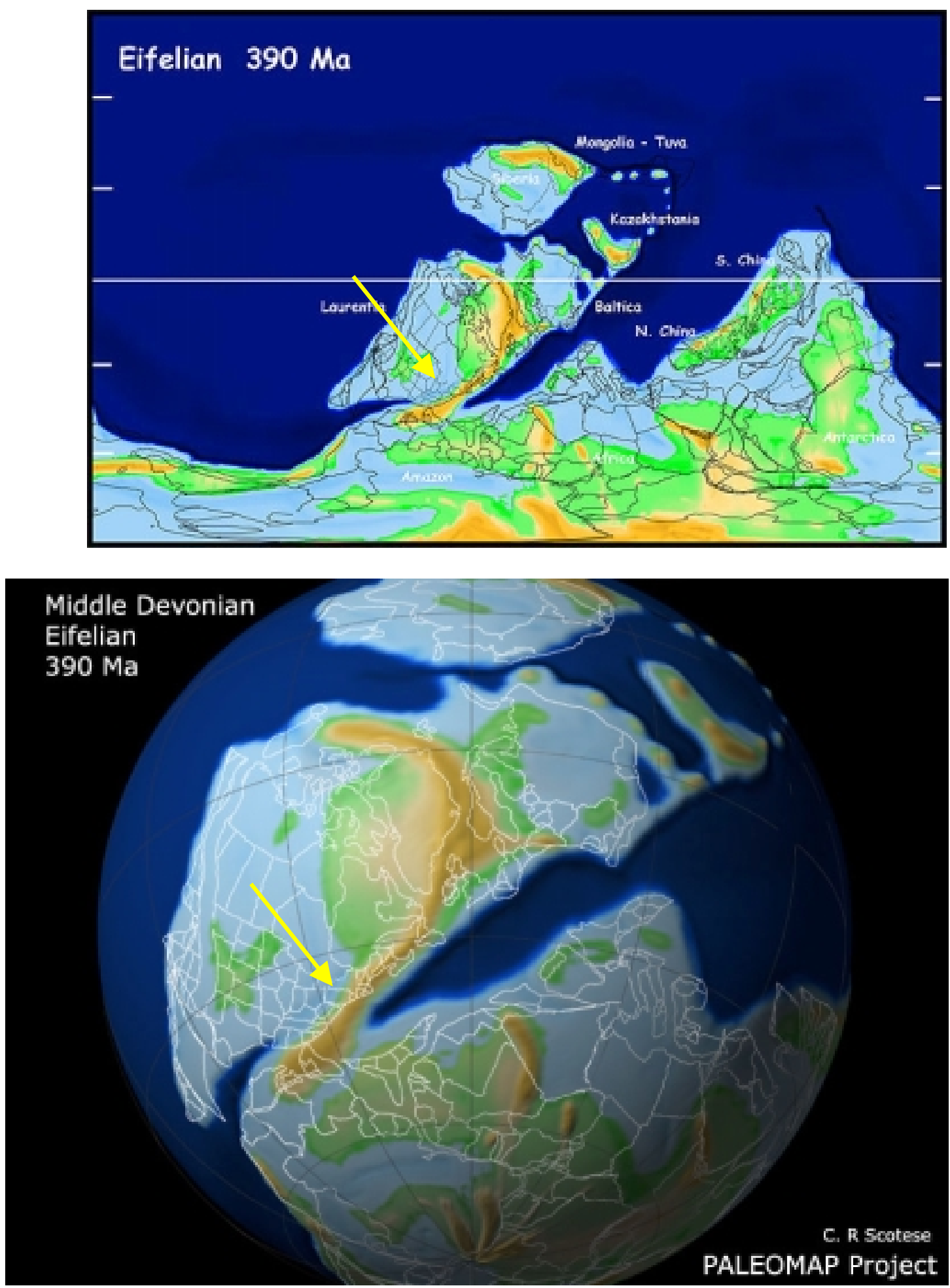

Figure 4: Paleogeography of the Eifelian (Scotese, 2002). Notice the position of New York and Ohio (arrow) at about 35 degrees south latitude. A thin sliver of deeper water occurs in New York but not central and northern Ohio. 


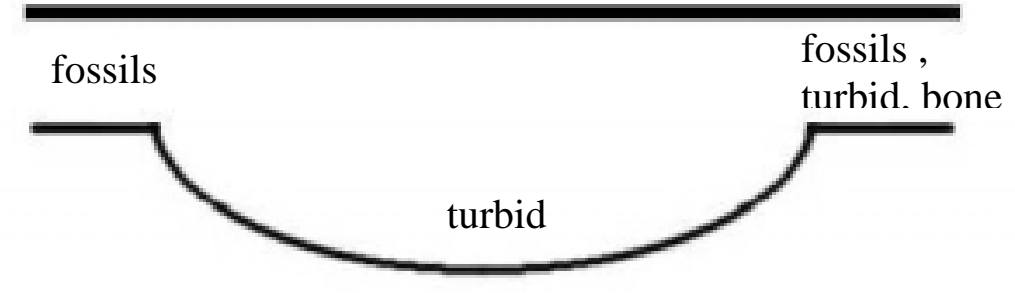

Moorehouse
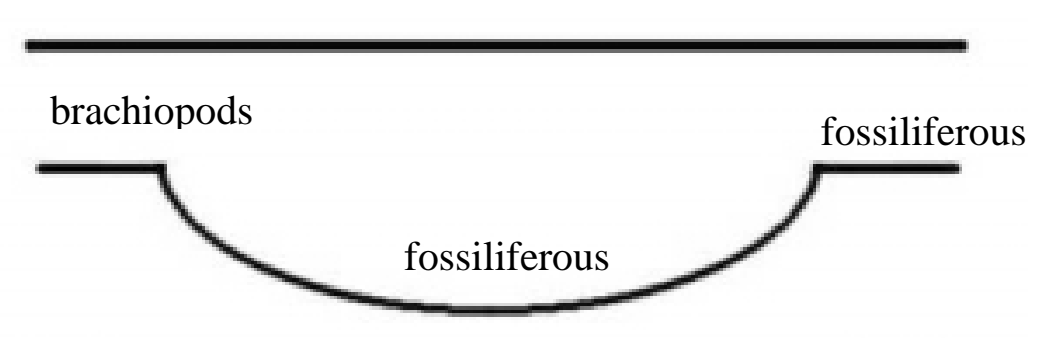

Clarence

bioherms

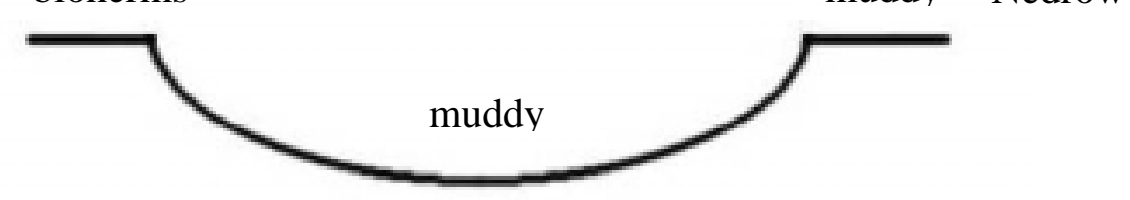

Edgecliff

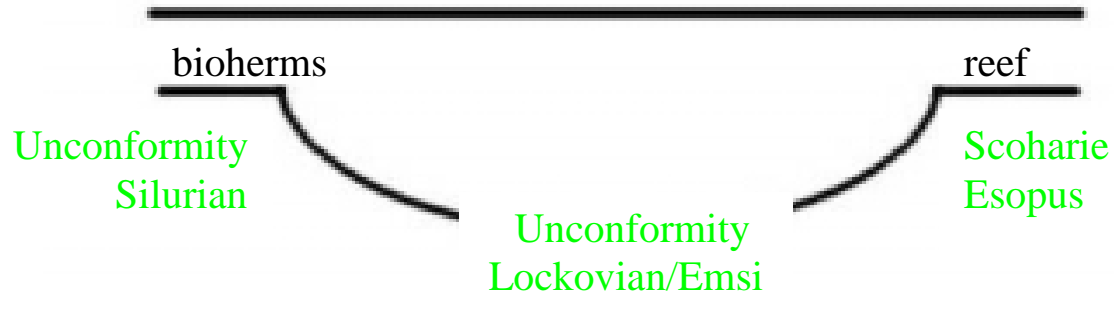

TST

West

East

Figure 5: Depositional environments of the Onondaga Formation, from eastern New York to the Buffalo area in western New York. 


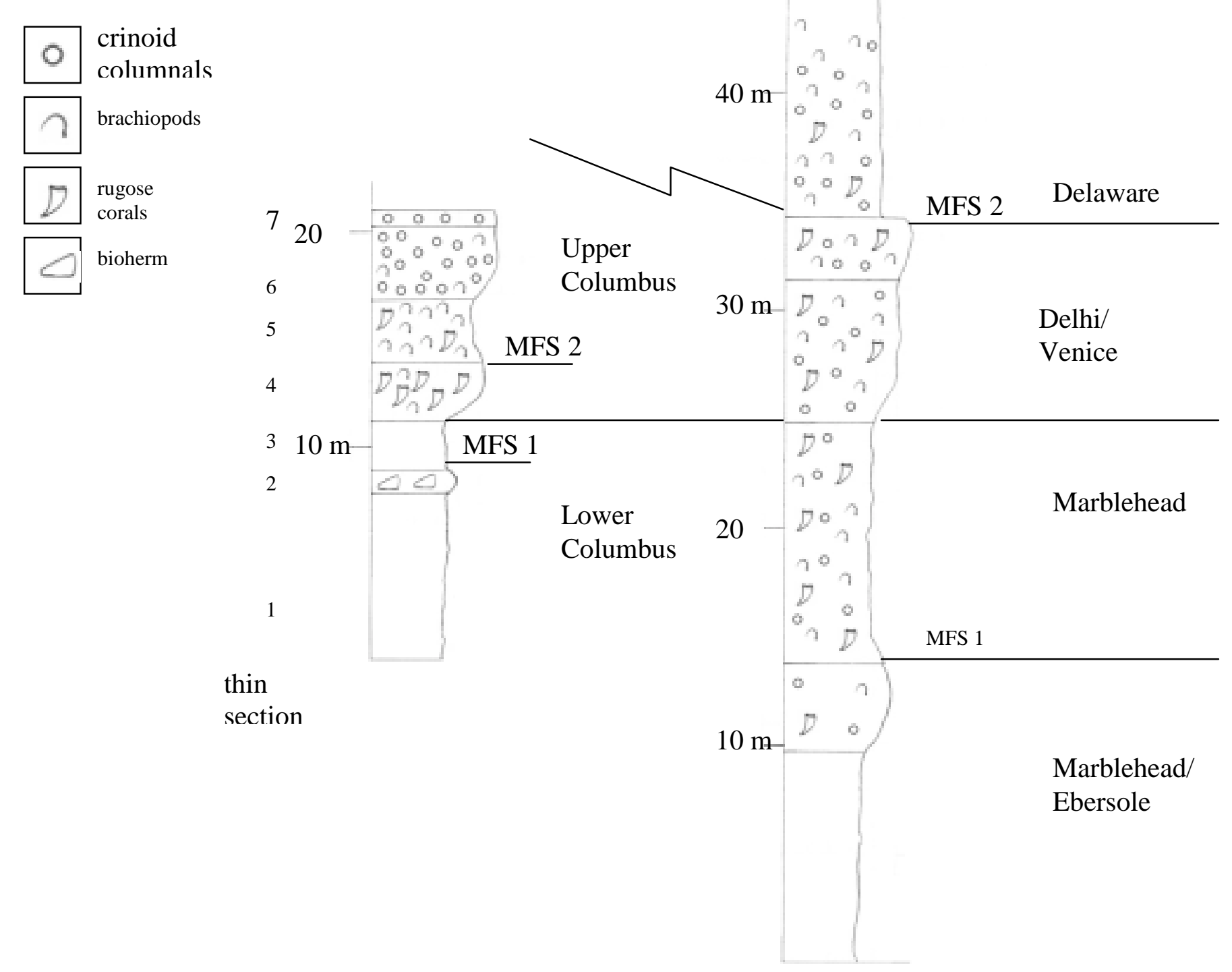

Figure 6: Stratigraphic sections of the Columbus and Delaware Limestones at the Warrensburg Quarry near Delaware, Ohio, and the Martin Marietta Quarry in Sandusky, Ohio. Maximum flooding surfaces are designated by 'MFS'. Thin section numbers are provided to the left of the Warrensburg column. 


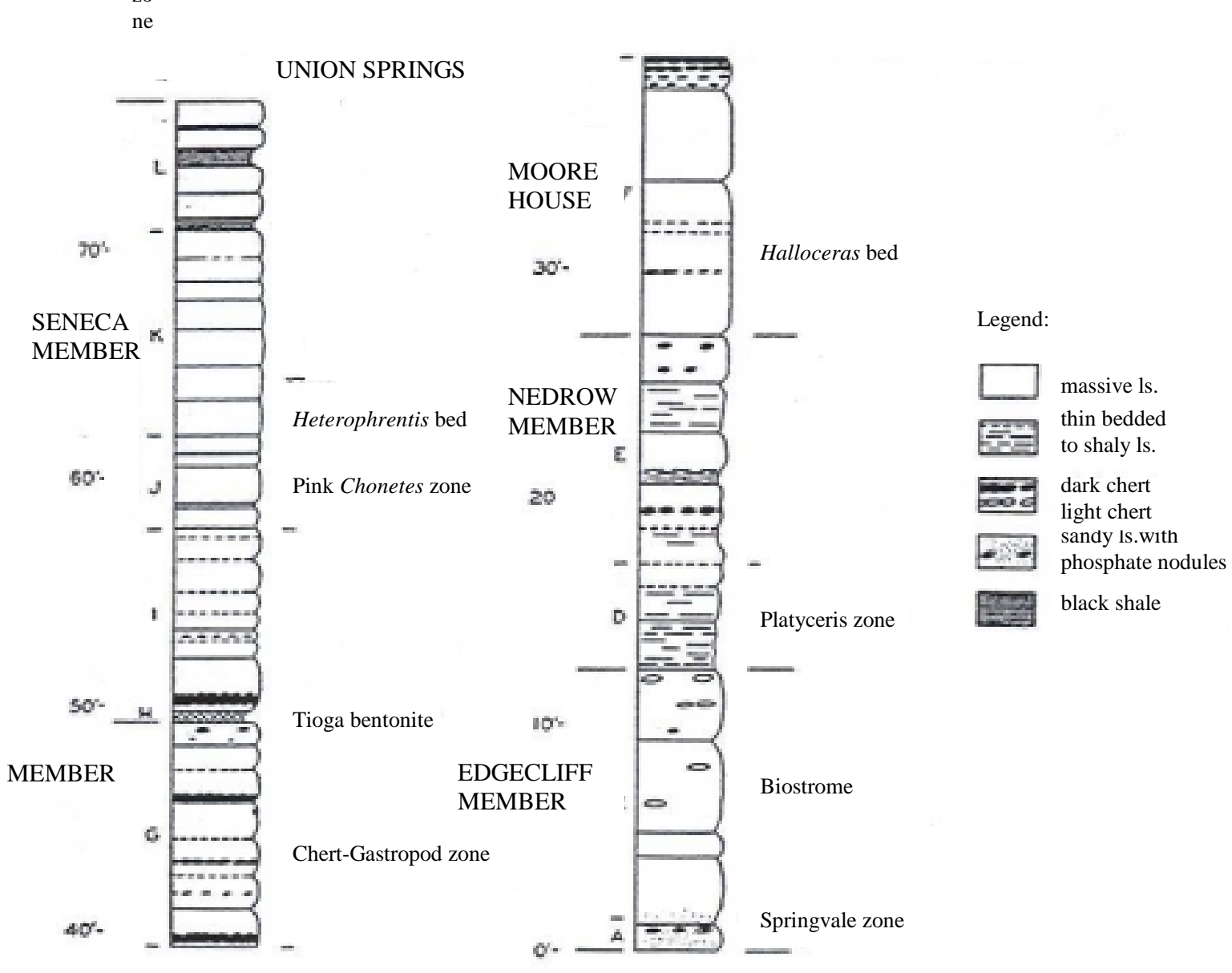

Figure 7: Stratigraphic column of Oliver (1954; Figure 2, modified) and the biozones within the members of the Onondaga. 


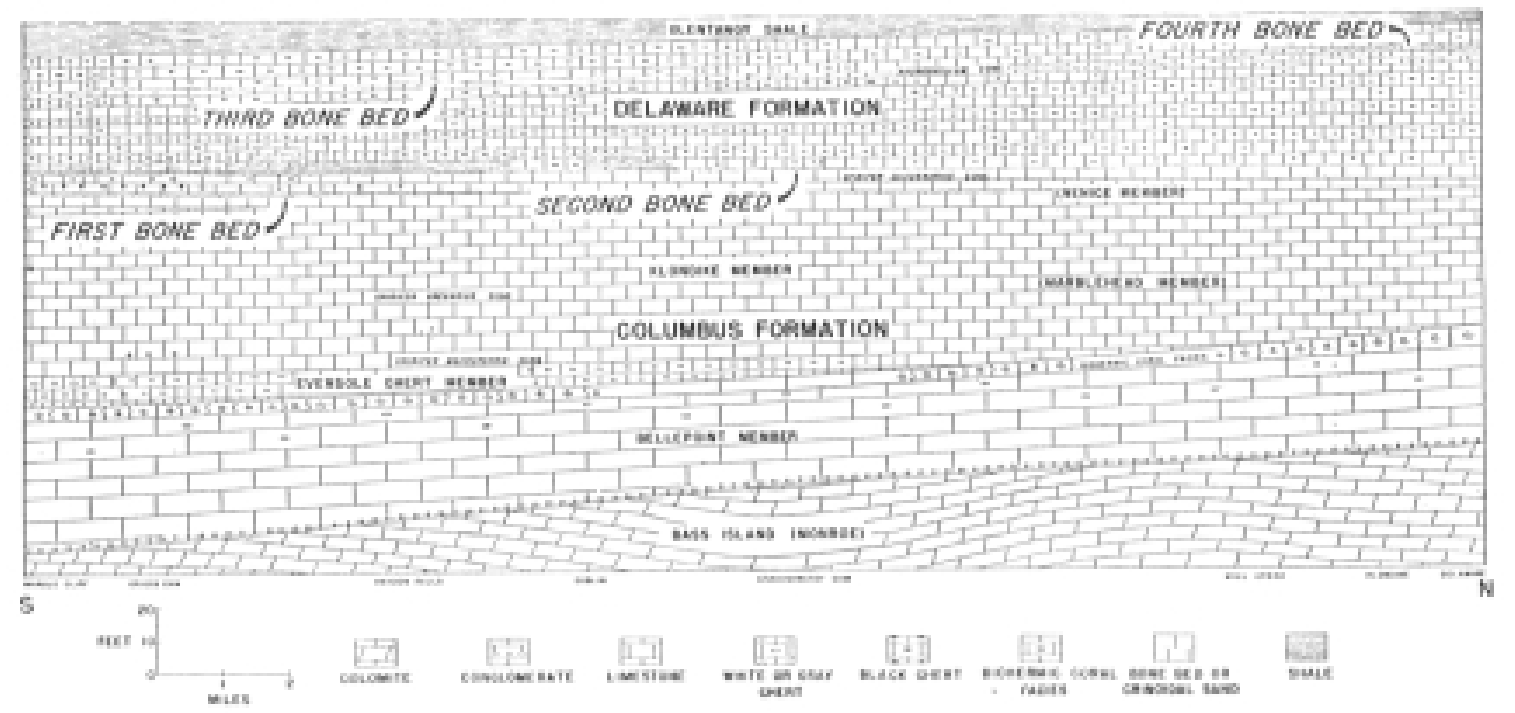

Figure 8A: Wells' (1947, Figure 1) identification of the location of bone beds within the Columbus and Delaware Limestones in central Ohio.

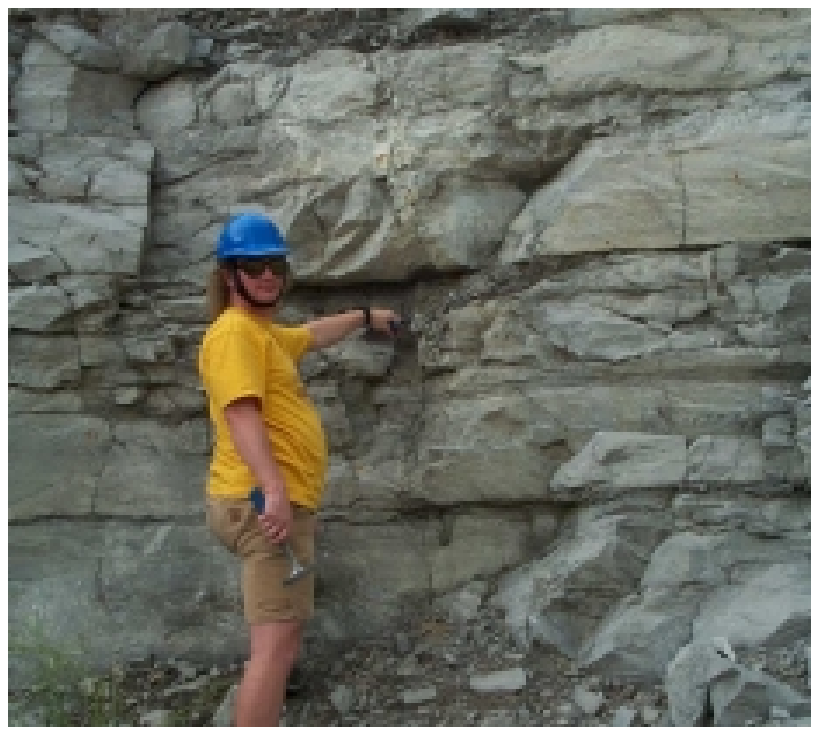

Figure 8B: Contact between the Columbus and Delaware Limestones at Sandusky, Ohio. Bone beds were not observed, but phosphatic material was present. 

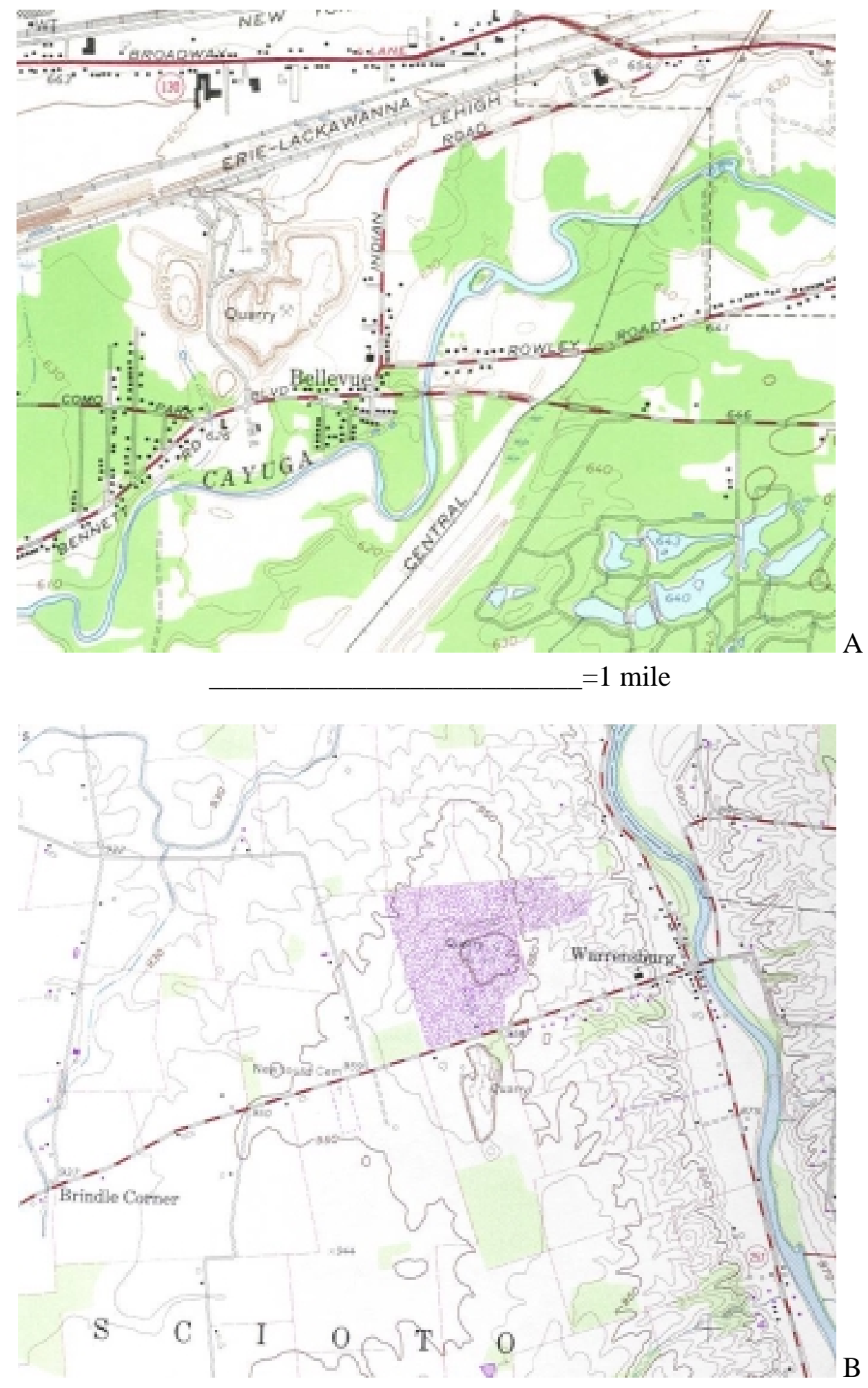

Figure 9A: Location of the Cheektowaga Quarry in the southwestern section of the USGS Lancaster 7.5' Quadrangle south of the town of Cheektowaga, New York. 9B: The location of the Warrensburg Quarry in the central portion of the Warrensburg 7.5' Quadrangle west of the town of Warrensburg, Ohio, and the Scioto River. 


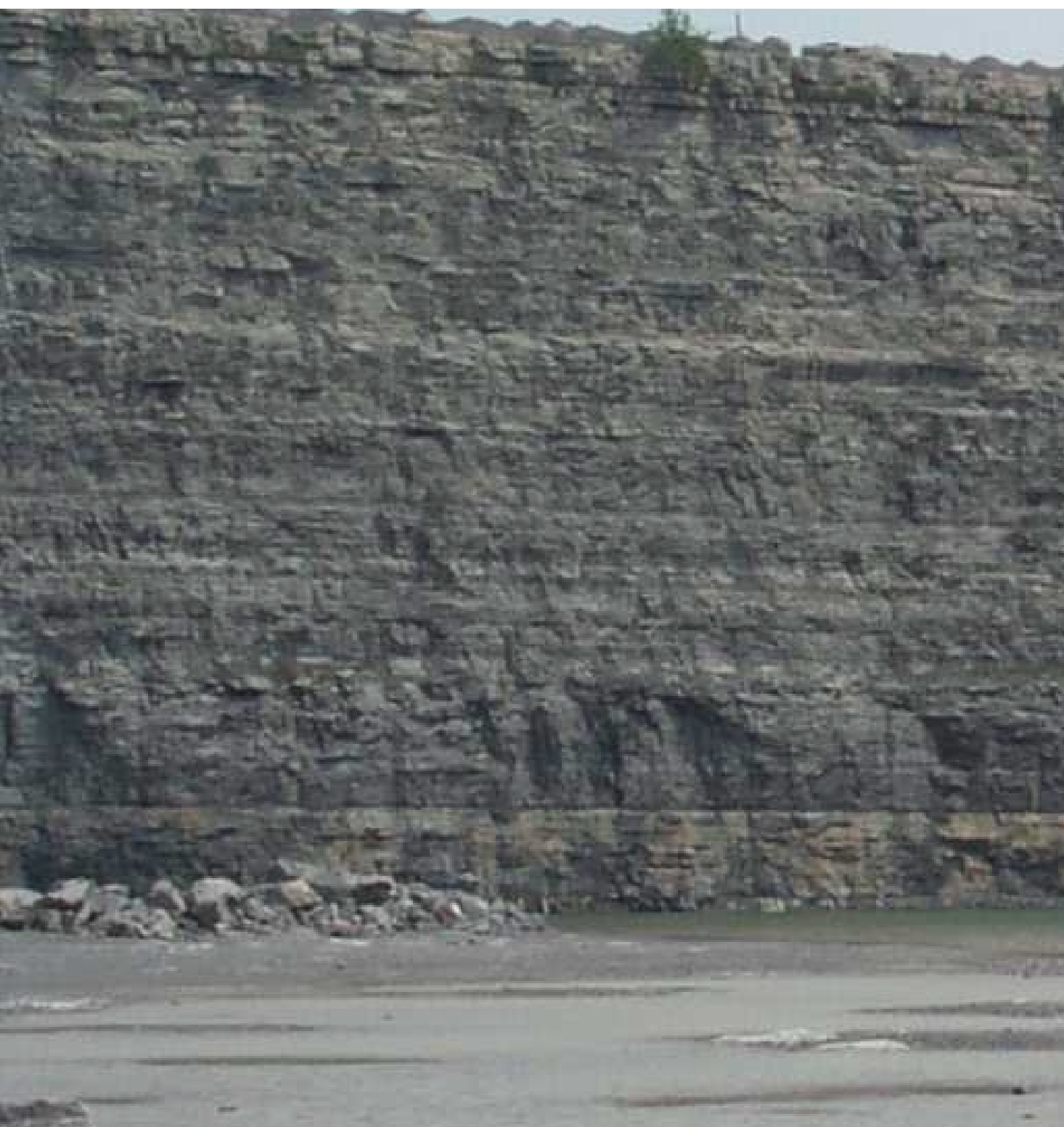

\section{Transition zone}

Light unit with bioherm

Moorehouse

Figure 10: Members of the Onondaga Formation exposed at the Cheektowaga Quarry. 


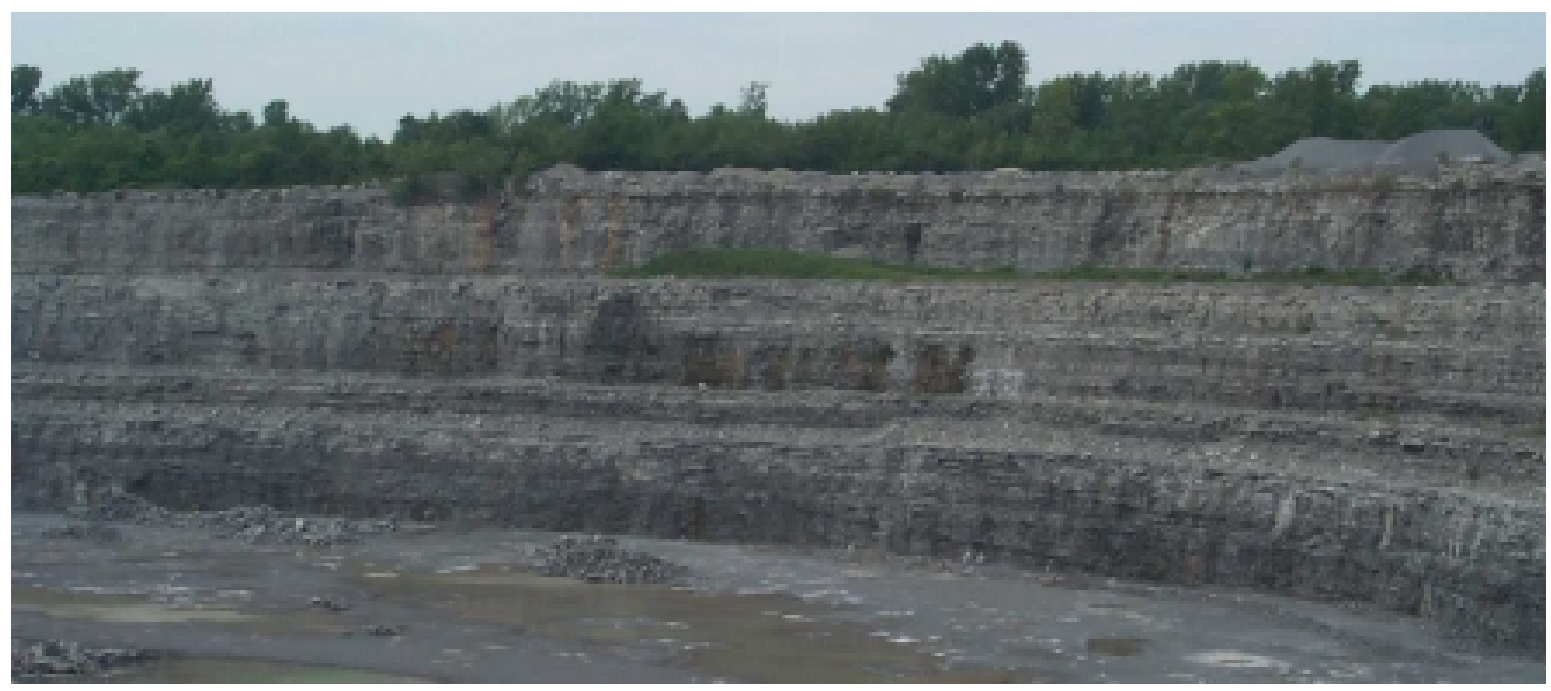

Figure 11A: Terraces at the Cheektowaga Quarry approximate member boundaries. The Seneca is visible on the north side of the quarry as a 2 meter unit resting above the Tioga Bentonite at the top of the section. The base of the Moorehouse Member begins at the top of the first terrace from the bottom. The entire wall is about 40 meters in height.

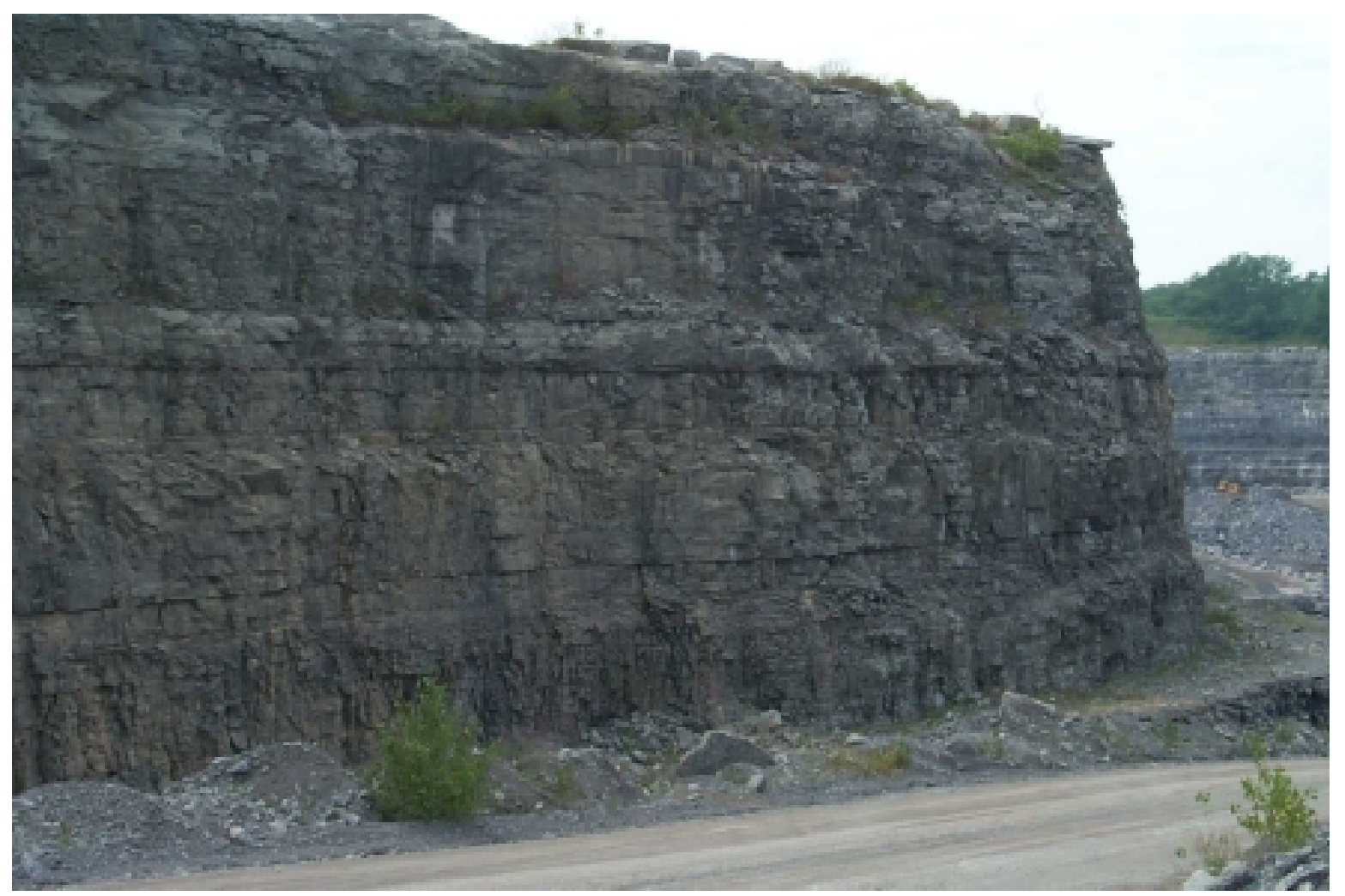

Figure 11B: Full exposure of the Moorehouse Member on the south side of the Cheektowaga Quarry. The Clarence bioherm is exposed just below the terrace in the right side of the photo. This coral layer is traceable across the quarry and is best developed on the west side, seen in the background of this photo. 

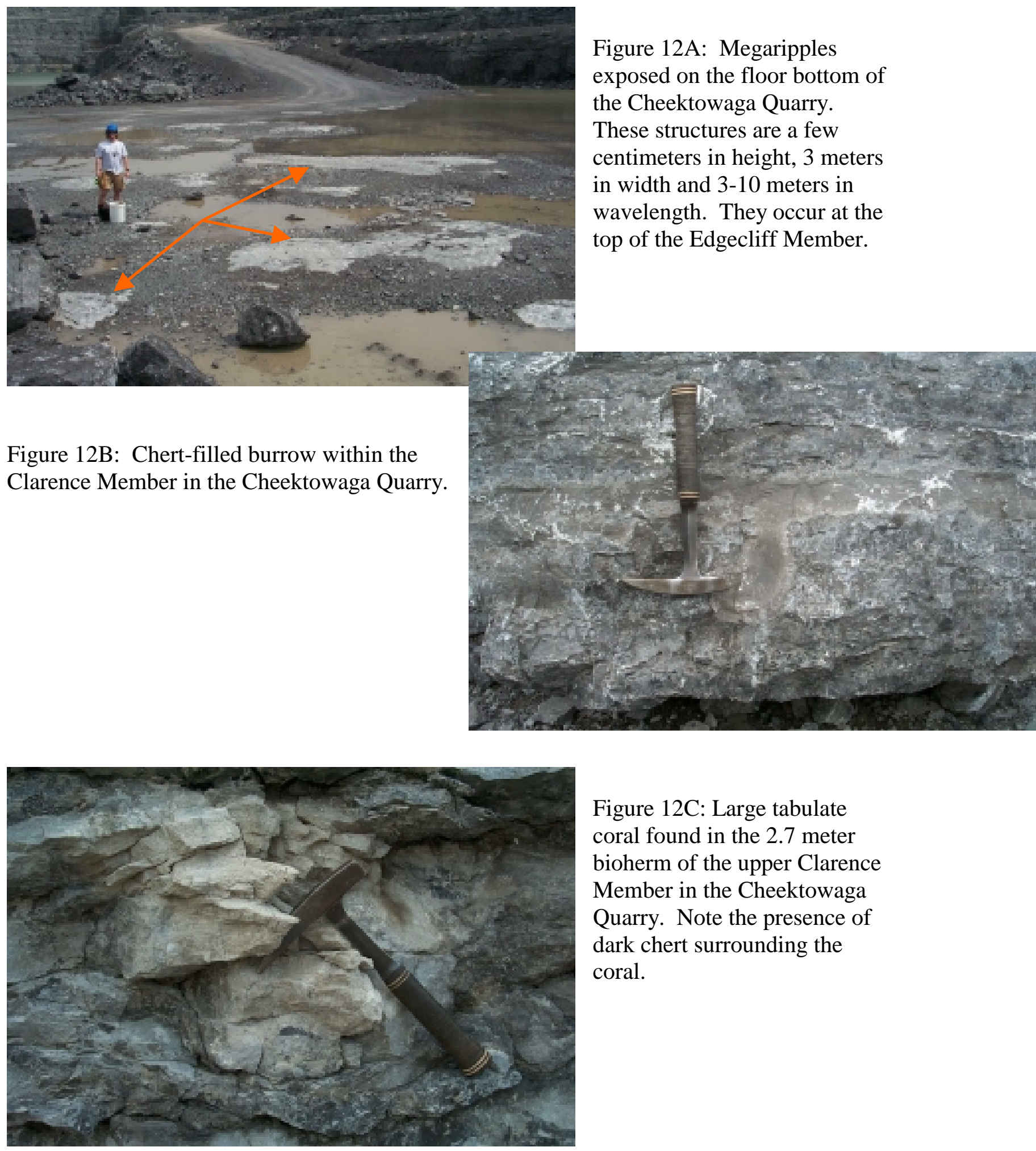

Figure 12C: Large tabulate coral found in the 2.7 meter bioherm of the upper Clarence Member in the Cheektowaga Quarry. Note the presence of dark chert surrounding the coral. 


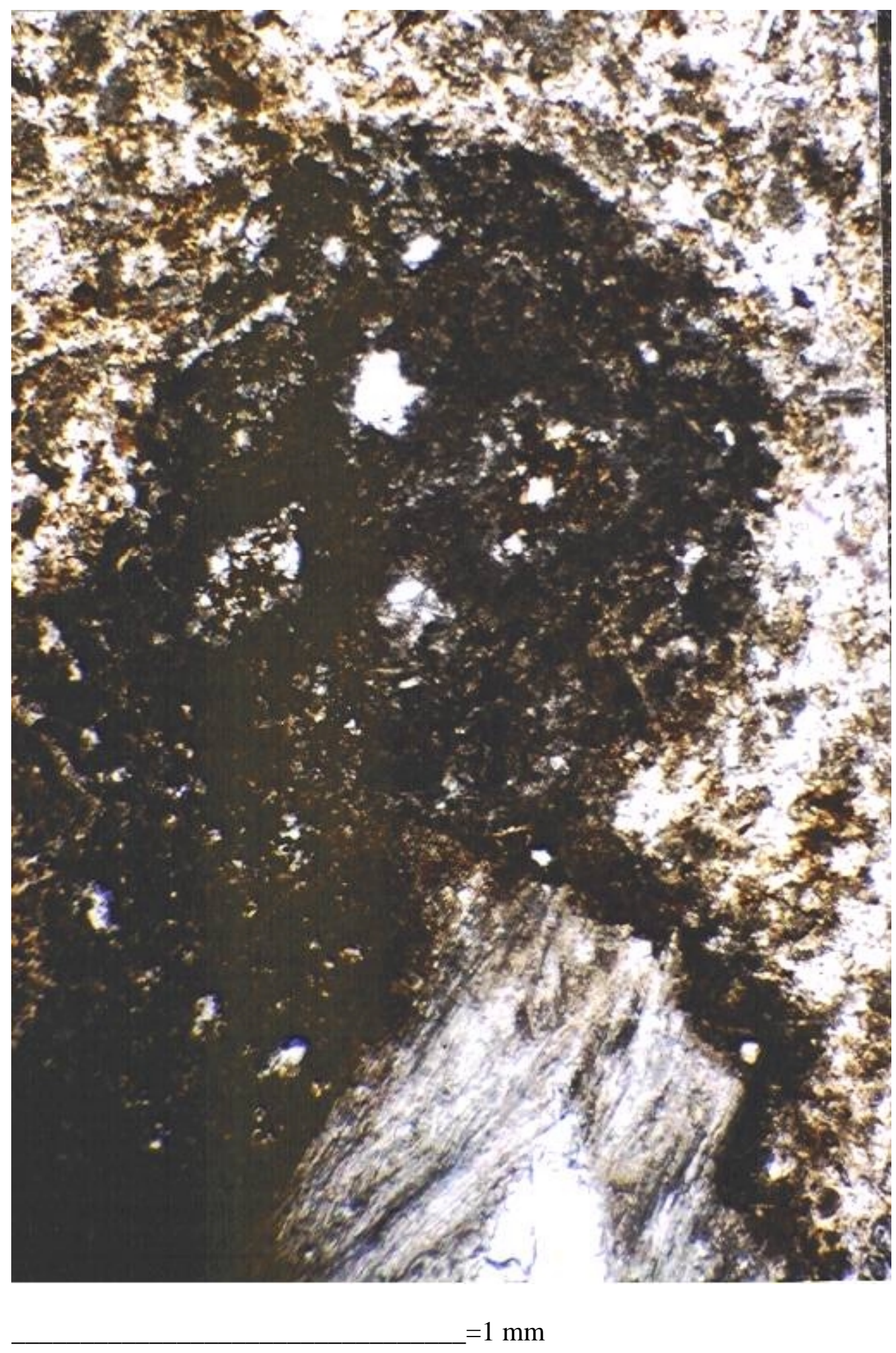

Figure 13: Calcareous algae found within the upper units of the Clarence Member. The algae is encrusting a large brachiopod. The field-of-view is about $2.5 \mathrm{~mm}$ in height. The image was photographed from a thin section in polarized light. 

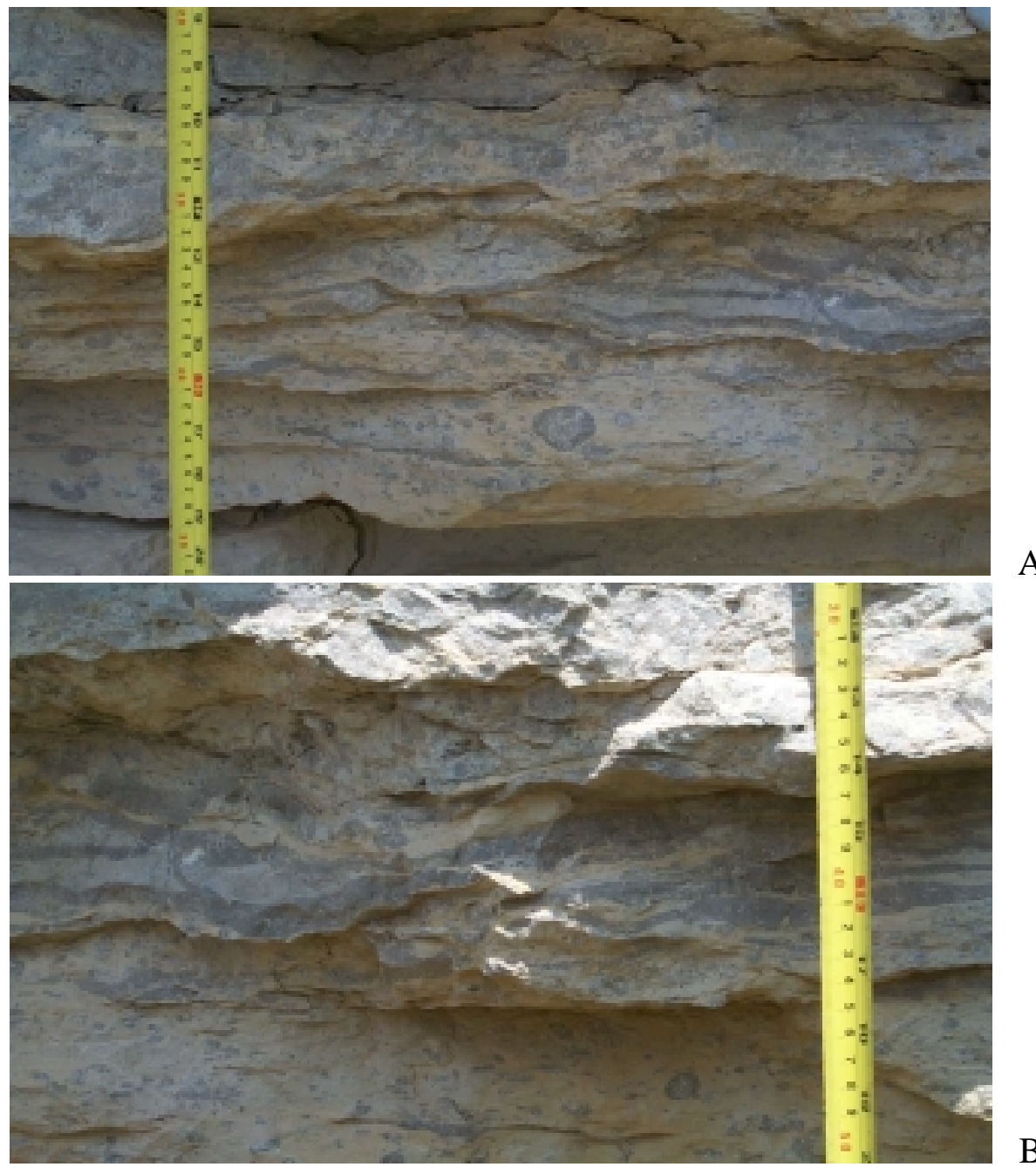

A
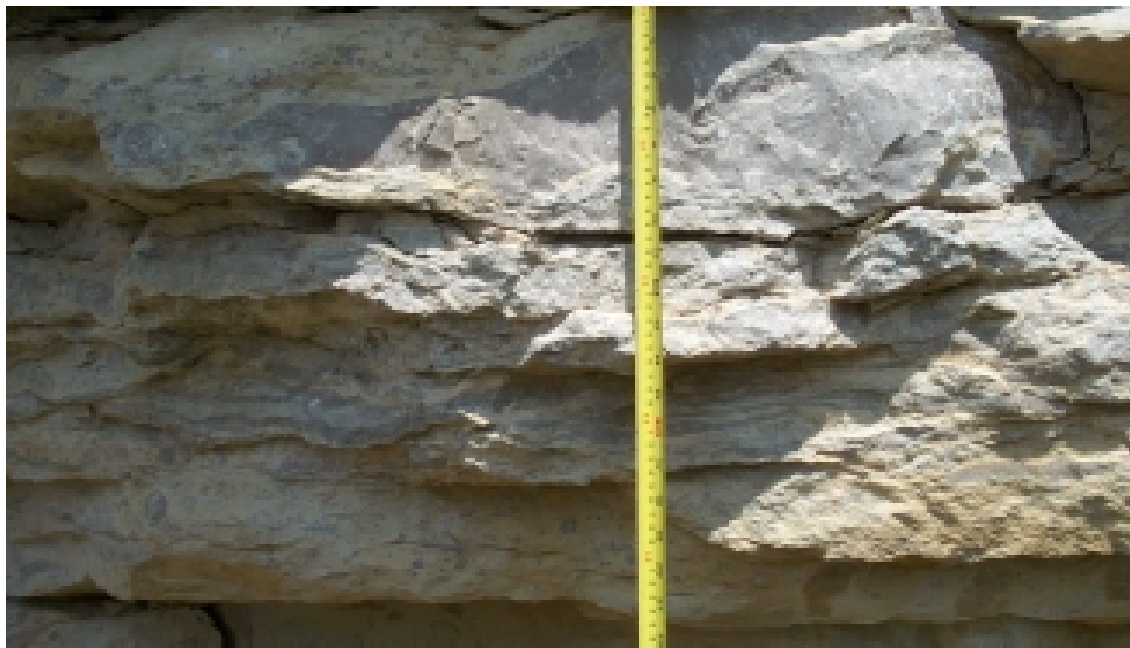

B

Figure 14A-C: Coral bed within the lower Columbus Limestone at the Warrensburg Quarry. 12A shows overturned rugose corals with stromatoporoids above. 12B shows a close-up of the stromatoporoid layer. $12 \mathrm{C}$ is a wider view that shows stromatoporoids and rugose corals. The stromatoporoids are in growth position, but the corals have been displaced. Units on the right of the tape are inches; units on the left are centimeters. 

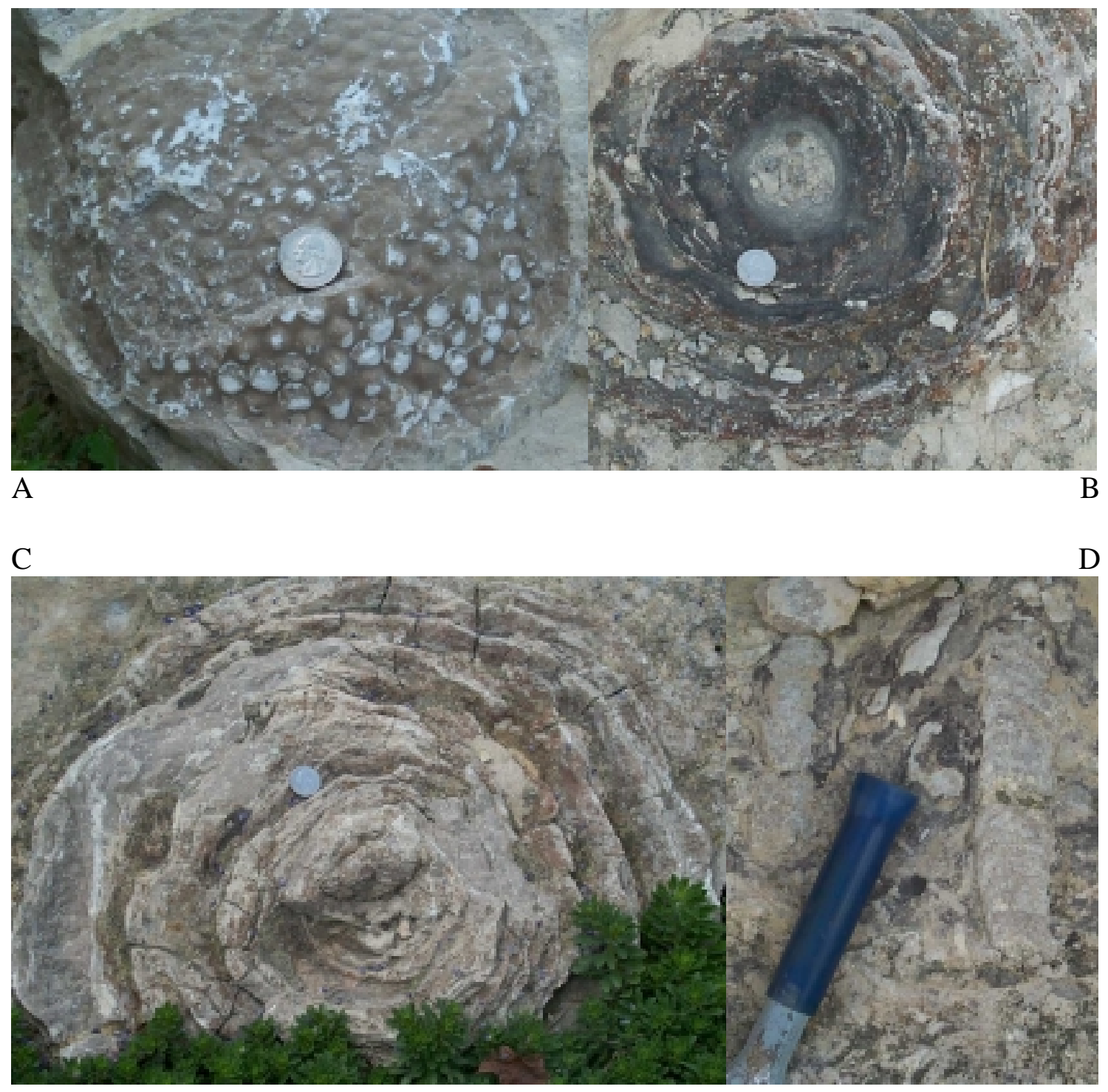

Figure 15: Stromatoporoids from the Warrensburg Quarry. Photographs A-C show stromatoporoids found in the rock garden surrounding the quarry office. All three were found in the quarry, probably from the bioherm of the upper units of the lower Columbus Limestone. Photograph, D, shows a cystiphylloid coral common within the bioherm. The coin in each photo is an American quarter dollar $(24 \mathrm{~mm})$. 


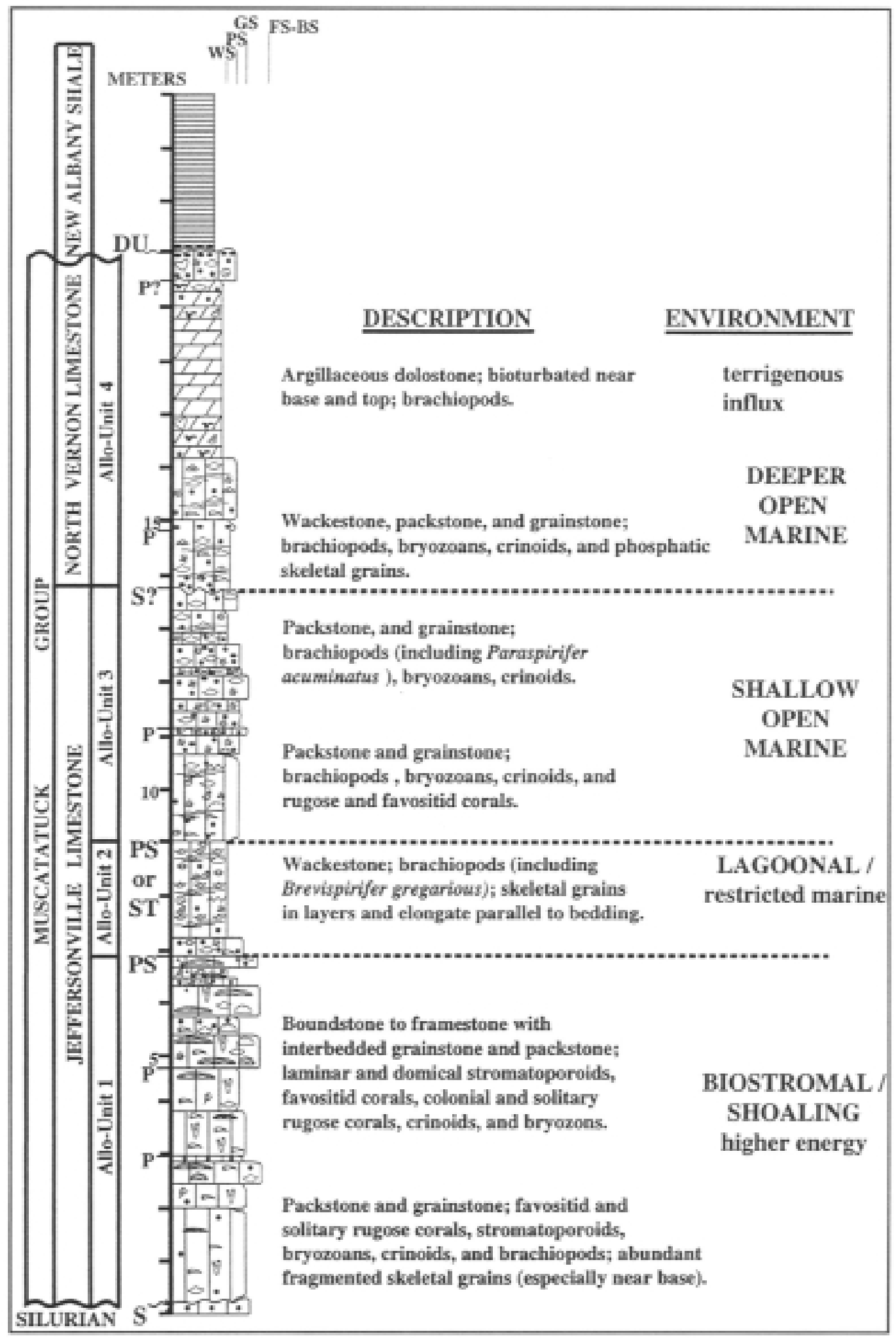

Figure 16: Stratigraphic section of Leonard (1996; Figure 5) from outcrops in southern Indiana. P=Flooding surfaces, PS=Parasequence boundaries, $\mathrm{ST}=$ Systems Tract boundaries. The Jeffersonville Limestone is correlative with the Columbus Limestone and the North Vernon Limestone is correlable with the Delaware Limestone. 

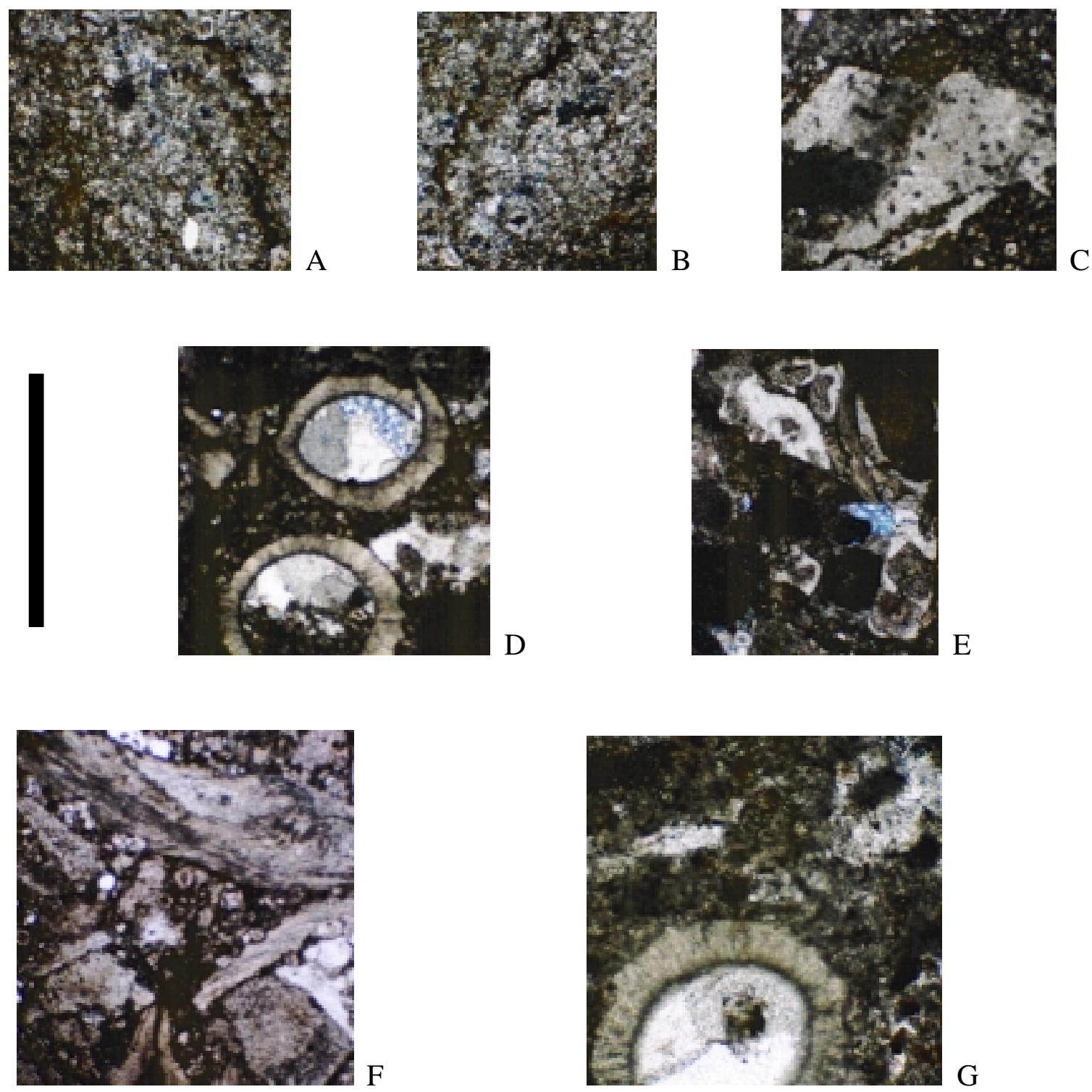

Figure 17: Thin sections of the units of the Columbus Limestone at theWarrensburg Quarry. Sections A and B (thin section 1) come from the fine-grained, deeper water units that are nonfossiliferous. Section $\mathrm{C}$ (thin section 2 ) shows a highly bored brachiopod from the coral zone. Sections D and E (thin section 4) are from the fossiliferous zone at the base of the upper Columbus. Section F (thin section 5) is from the same fossil zone, but higher in the section. Section $\mathrm{G}$ is from the fossil hash layer near the top of the Columbus (thin section 6). The scale bar to the left of $15 \mathrm{D}$ represents one millimeter. 


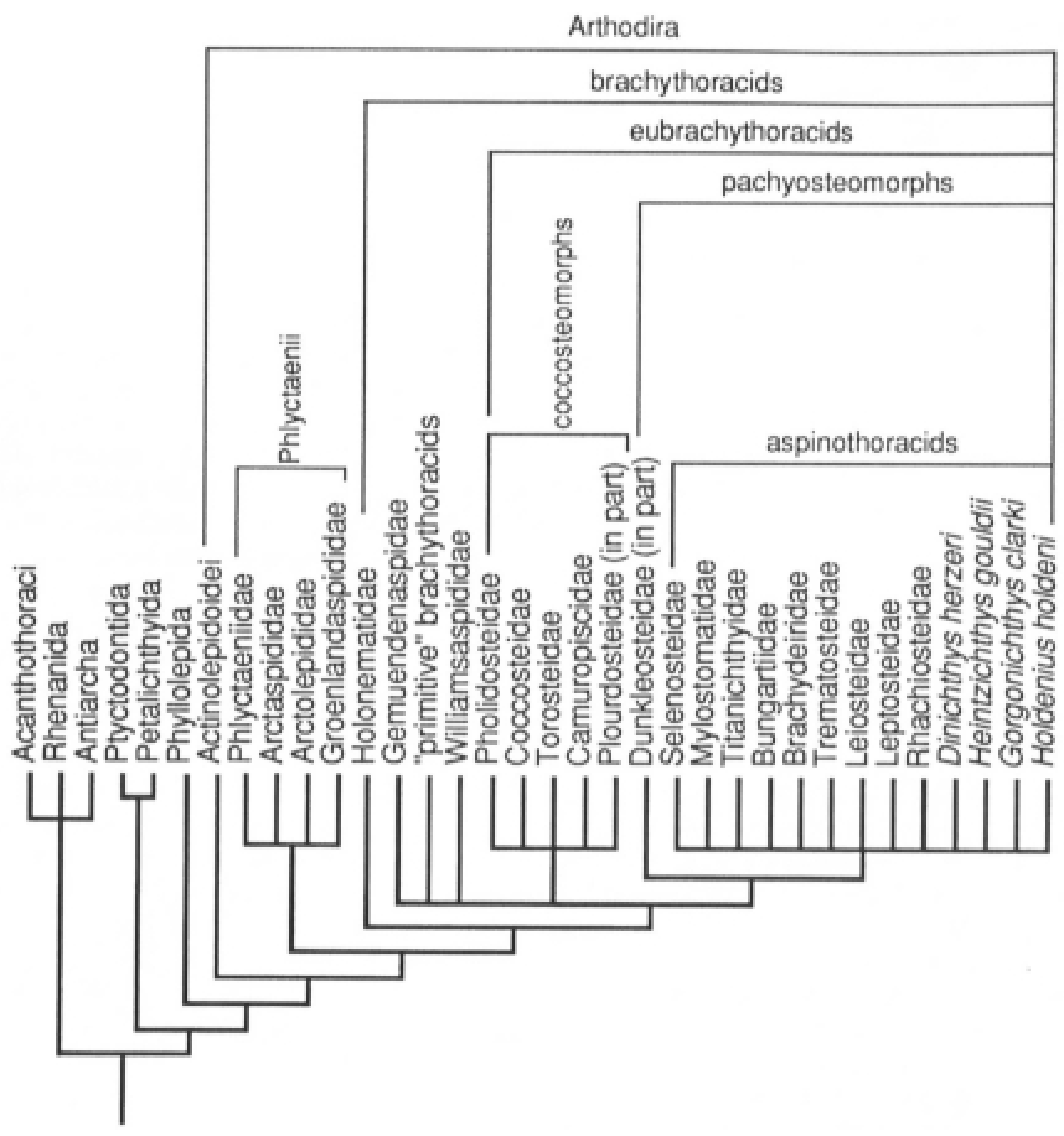

Figure 18: Recent cladogram showing the modern theory of placoderm interrelationships (Carr, 1995; Figure 4). Notice that the ptyctodonts and petalichthyids are sister groups, and represent an early outgroup to phyllolepids + arthrodires. 

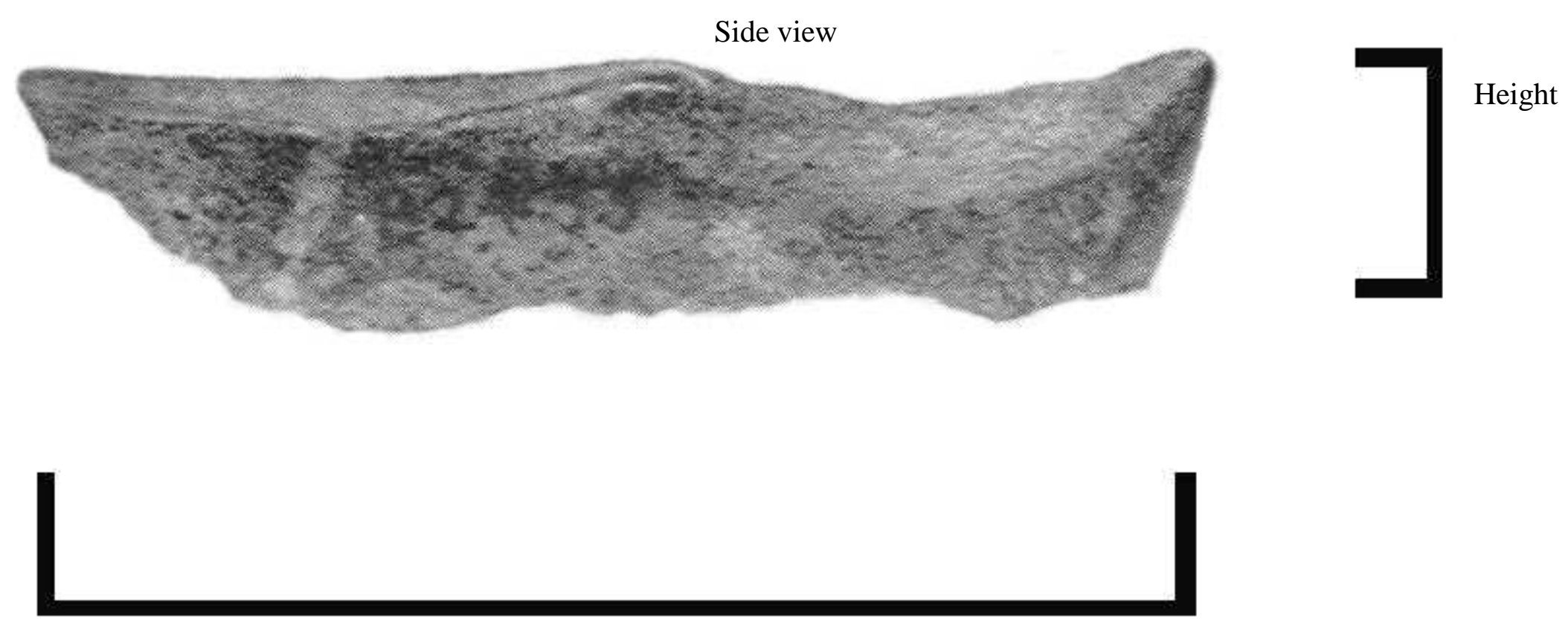

Length

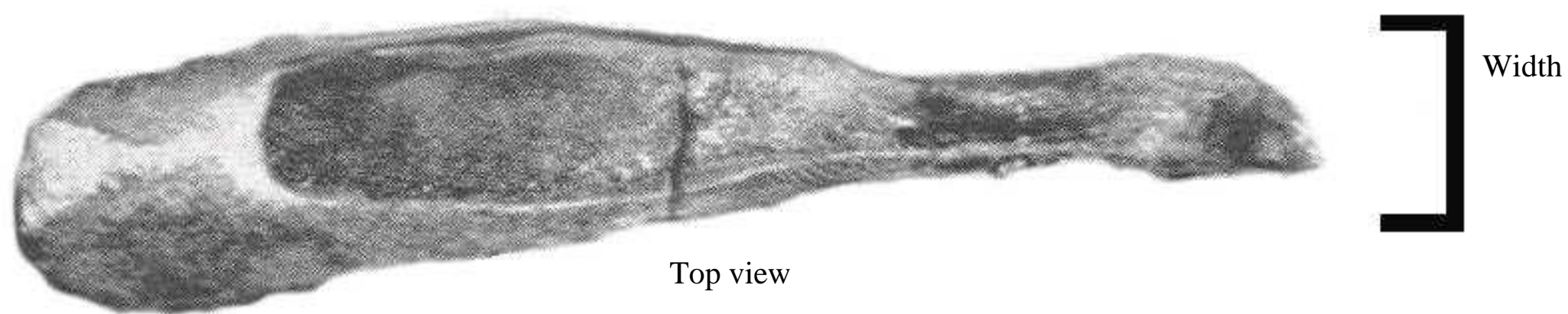

Figure 19: Dimensions of a ptyctodont dental element as described in the text. For descriptive purpose, the masticating surface is referred to as the dorsal surface. 


\section{Plates}

Plates contain images of specimens discussed in the text.

Scale bars represent one centimeter $(1.0 \mathrm{~cm})$. Specimens associated with the prefix, BW-3 are from the Baldwin-Wallace Collection at the Cleveland Museum of Natural History and those with the prefix OC are from the Oberlin College collection, also at the Cleveland

Museum. Those with the letter, 'E', are from the Buffalo Museum of Science. Most specimens are imbedded in matrix so that the exact orientation of the fossil is impossible to decipher. 
Plate 1: Macropetalichthys sullivanti Norwood and Owen (1846).
A: Lateral reconstruction (from Denison, 1978; Figure 5).
B: Dorsal reconstruction (from Denison, 1978; Figure 25).
C: Anterior lateral (top) and anterior ventrolateral/spine plates (Denison, 1978; Figure 27).
D. Lunaspis, a petalichthyid from Australia (Denison, 1978; Figure 26) 


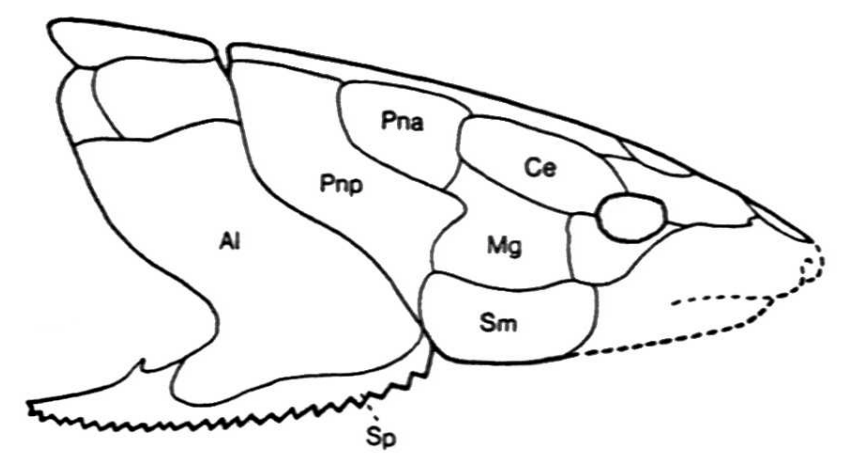

A

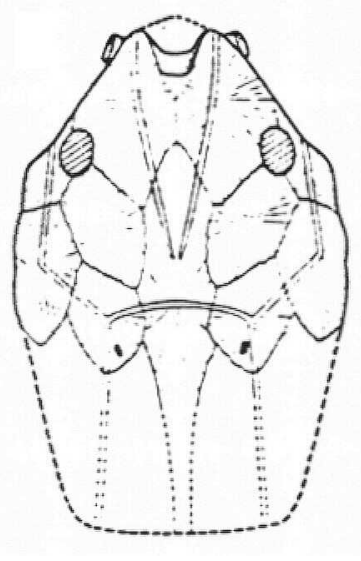

B
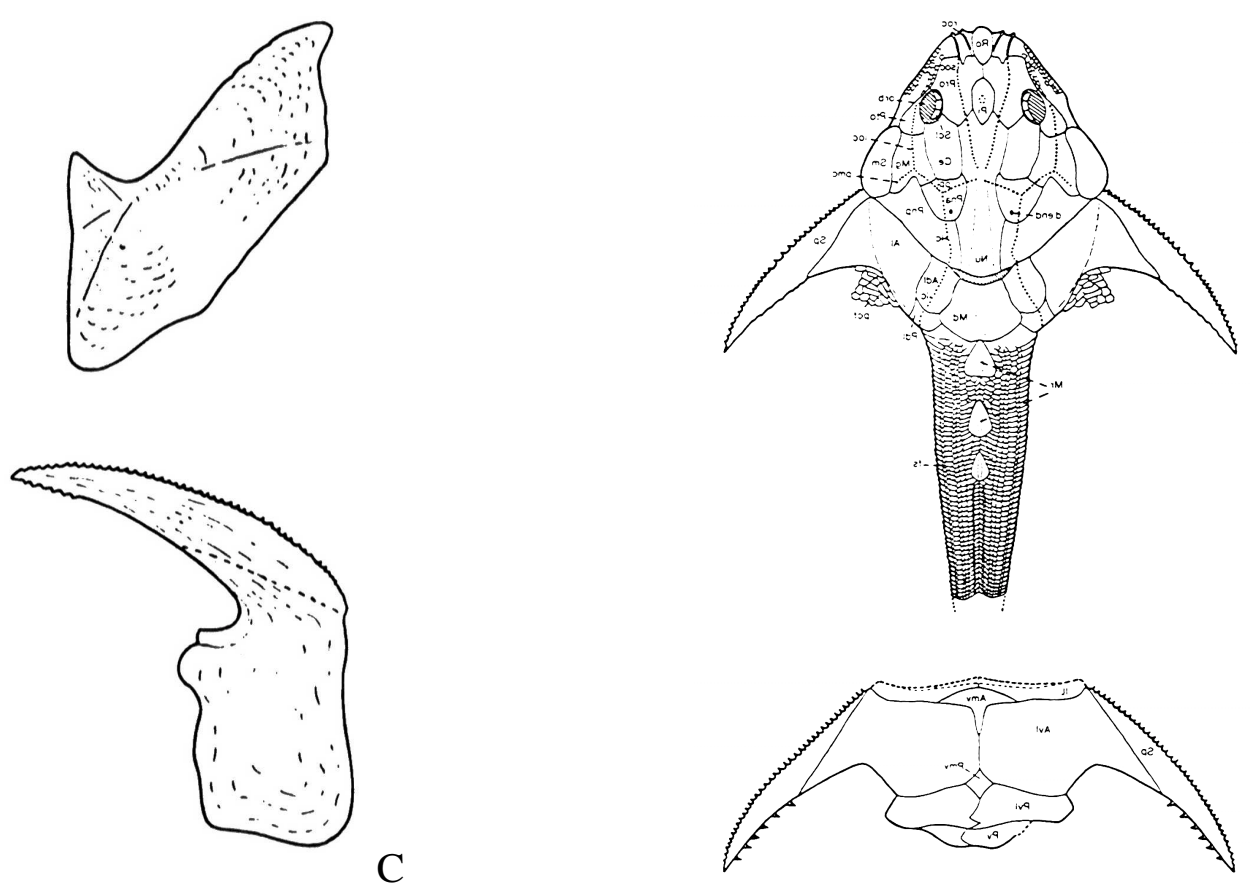

D 
Plate 2: Ptyctodonts and an extant chimera.

A: Reconstruction of ptyctodont heads (from Denison, 1978; Figure 17).

B: Cranial bones of a ptyctodont (from Denison, 1978; Figure 16).

C. Callorhynchus, modern chimera for comparison (from Long, 1995; page 83).

D: Campbellodus, a Devonian ptyctodont from Australia (from Long, 1995; page 110).

E: Ischyodus, a Carboniferous chimera (from Maisey, 1996; Plate 34). 

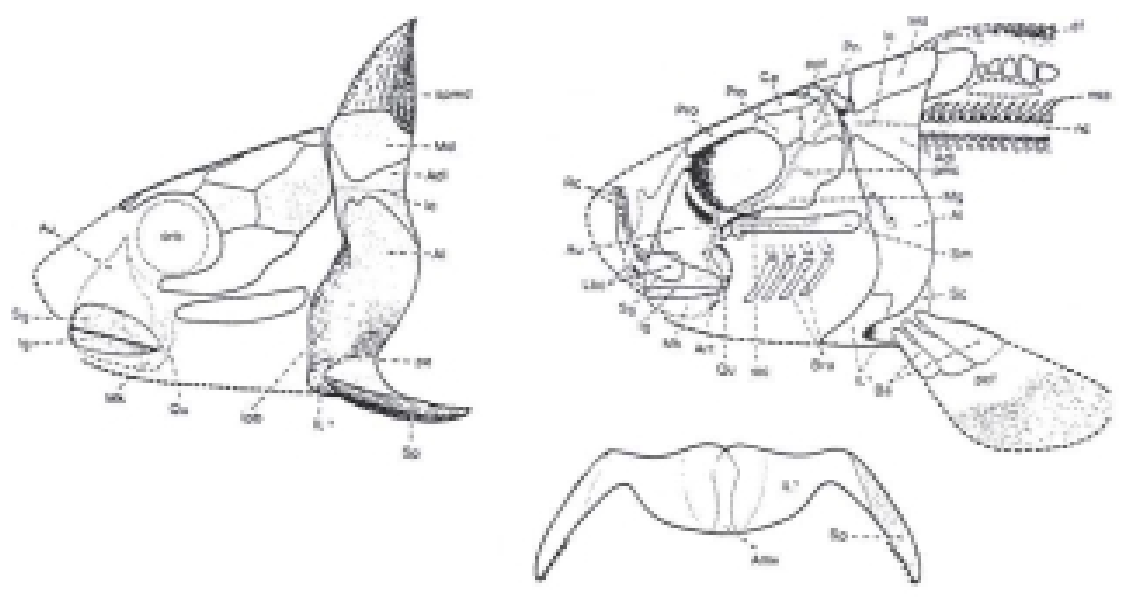

A
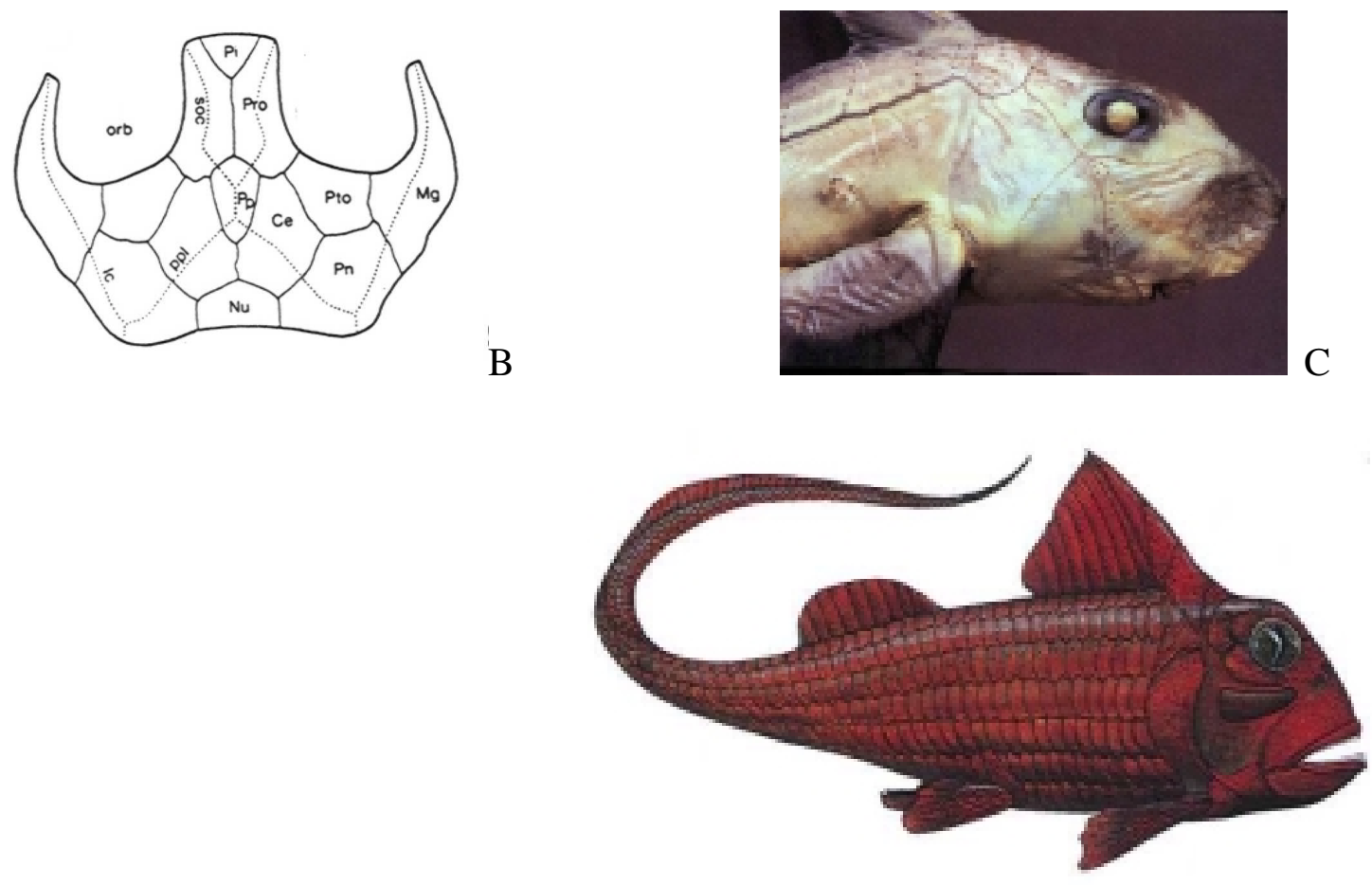

D

E

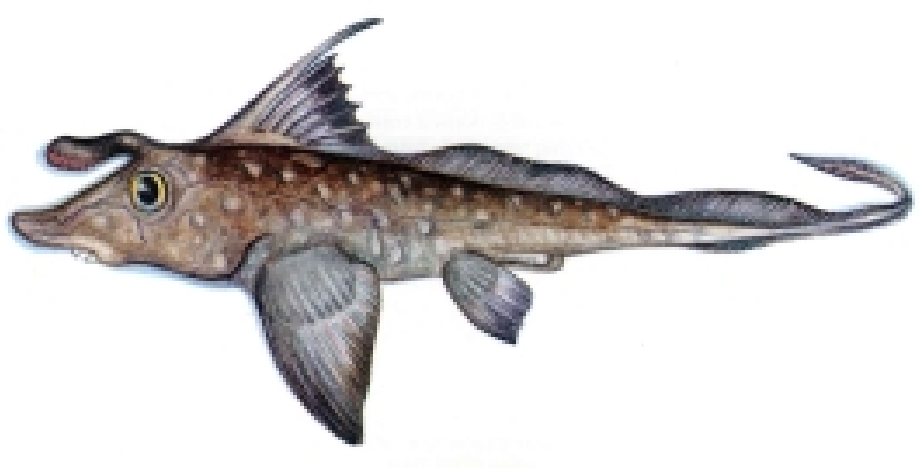


Plate 3: Ptyctodus Pander (1858). Scale bar=1 cm.

A: Labial view of a right, lower Ptyctodus dental element (from Hussakoff and Bryant, 1918; Plate 36, Figure 11).

B: Lingual view of a well-worn, right, lower dental element (from Hussakoff and Bryant, 1918; Plate 34, Figure 3).

C: Dorsal crushing surface of a left, lower Ptyctodus dental element (from Hussakoff and Bryant, 1918; Plate 34, Figure 1).

D. E12203, formerly labeled as Paraptyctodus; Probably the right, lower dental element. E. E17945, formerly labeled as Macropetalichthys. 


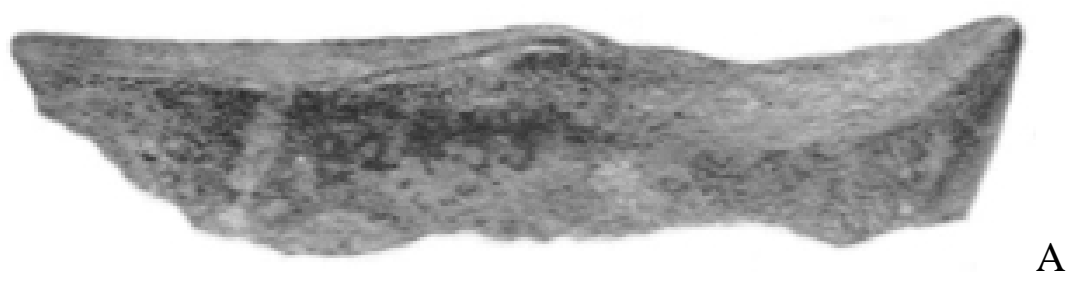

A
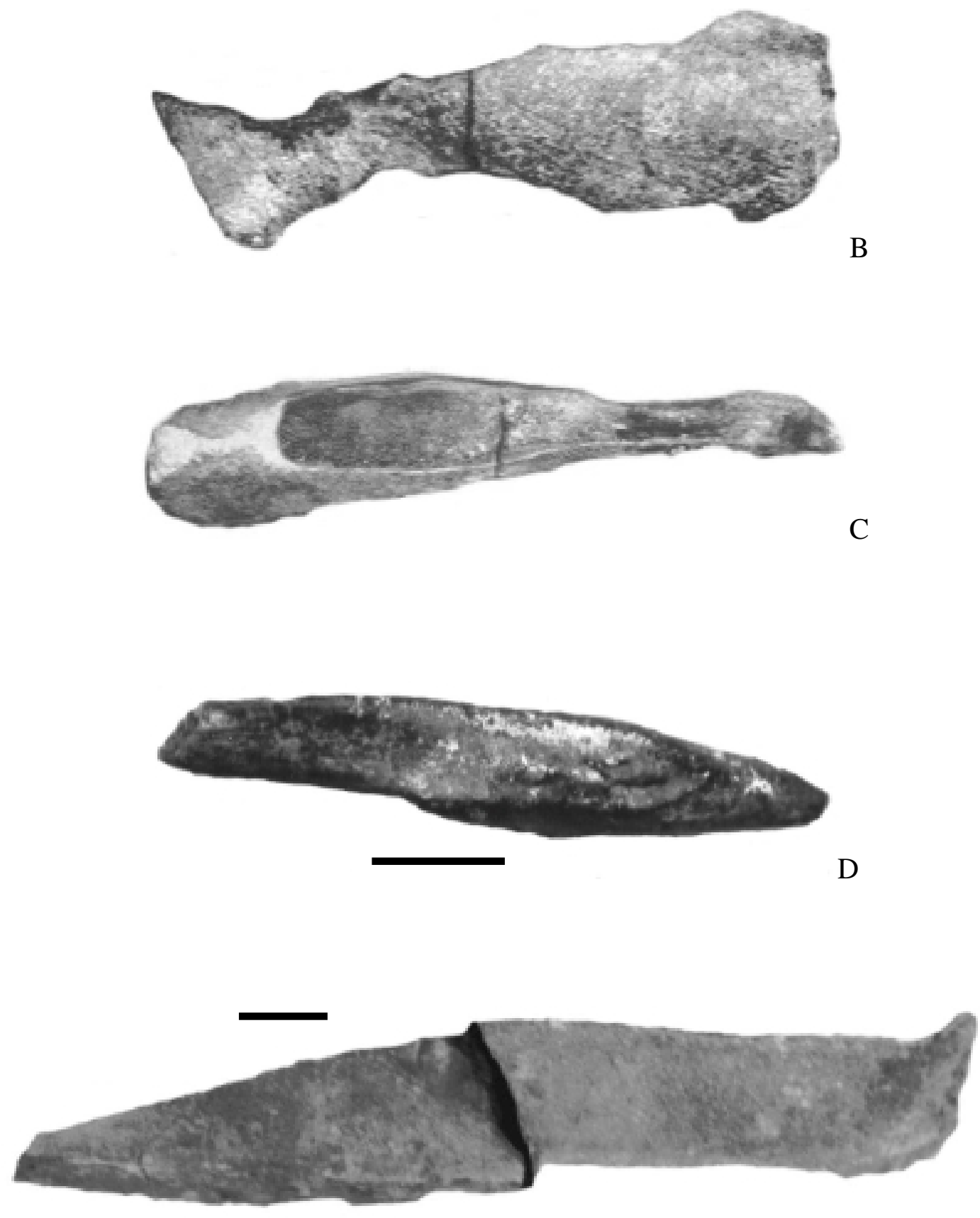

E 
Plate 4: Palaeomylus Woodward (1891). Scale bar=1 cm.

A: E7765; Notice that the tritoral surface possesses three cusps. Upper?, left? dental element.

B: E18223; Labeled as Rhynchodus frangens, but it is Palaeomylus frangens.

C. Line drawing of the upper? dental plate of Palaeomylus. 

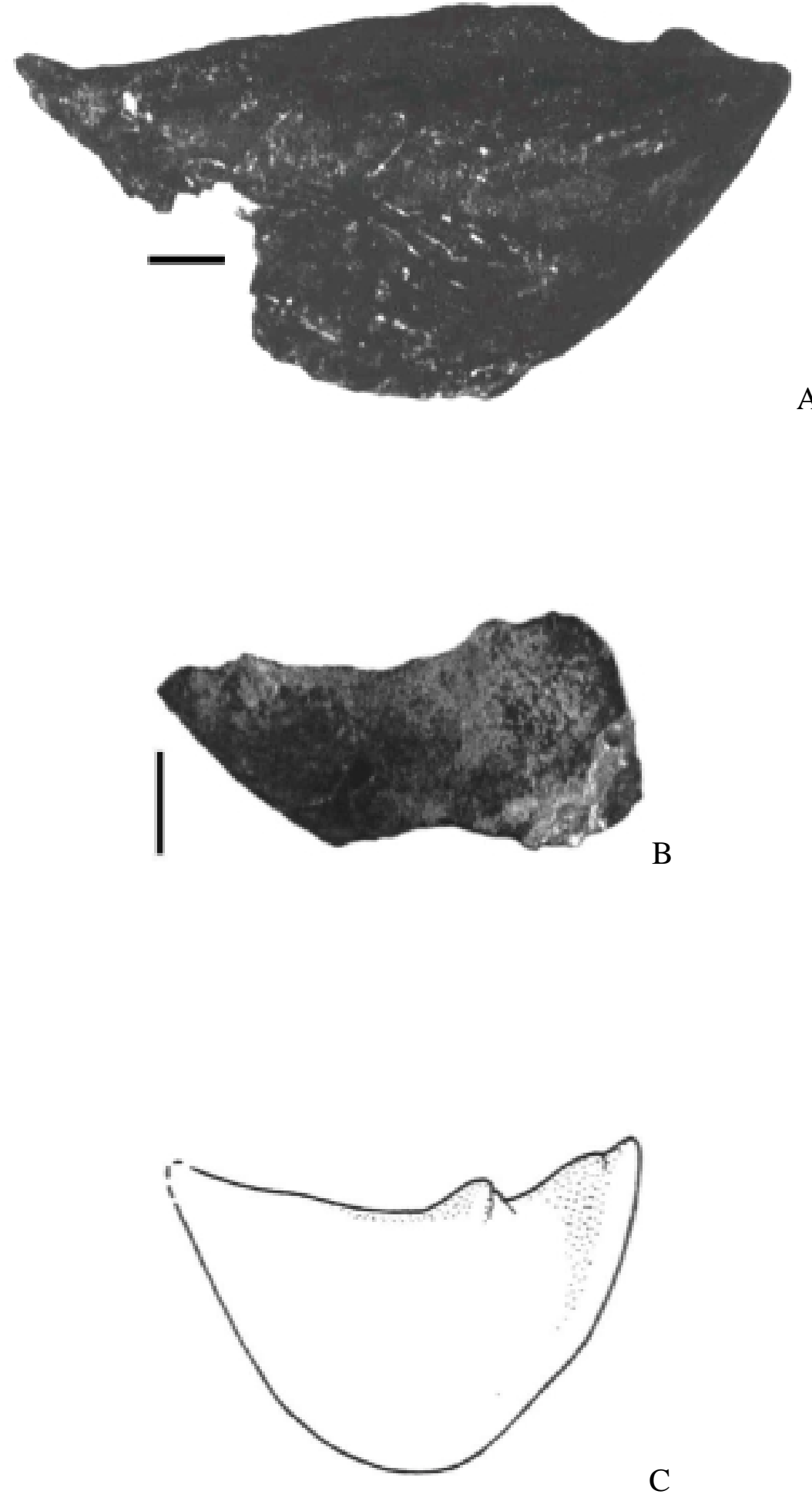

119 
Plate 5: Rhynchodus Newberry (1873). All specimens are lower? dental plates. Scale bar=1 $\mathrm{cm}$.
A: BW-3-155.
B: BW-3-418.
C. BW-3-504.
D: BW-3-31; right side.

E: BW-3-364.

F: BW-3-466.

G. Line drawing of Rhynchodus showing the upper ( $\mathrm{Sg}=$ superognathal) and lower (Ig= inferognathals) dental plates (Dennison, 1978; Figure 18). 


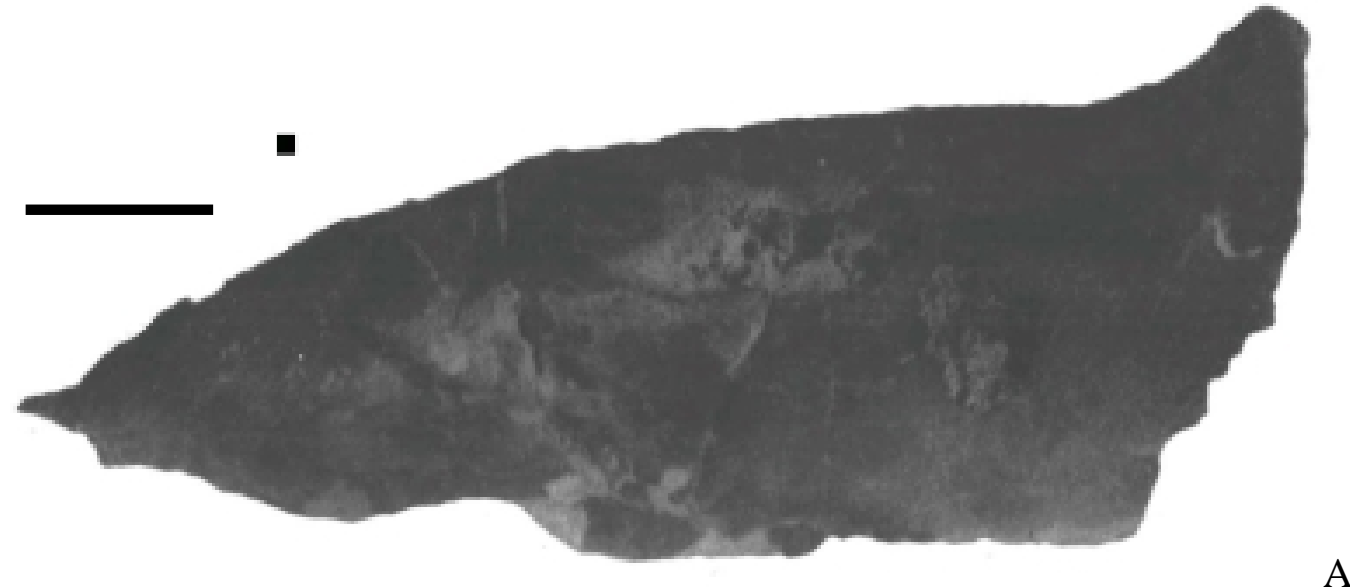

A
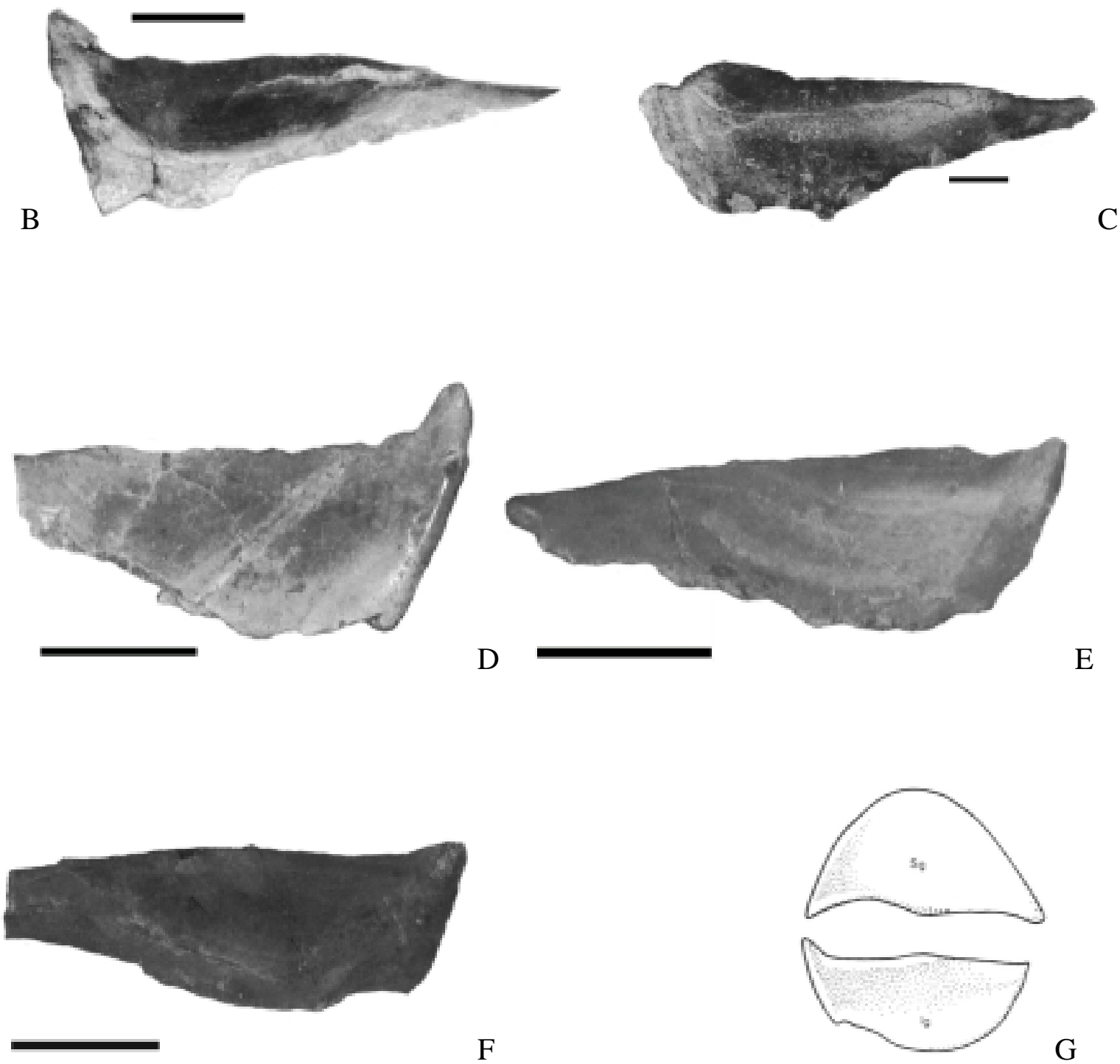
Plate 6: Specimens misidentified as Rhynchodus. Scale bar=1 cm.

A: BW-3-106; possesses tubercles reminiscent of Deinodus bennetti.

B: BW-3-179; similar to the dental plates of Deinodus ohioensis.

C: BW-3-144; probably the anterior lateral plate of some ptyctodont, though not necessarily Rhynchodus.

D: BW-3-84; probably a ptyctodont dental plate, but not Rhynchodus.

E: BW-3-195; may be a partial dental plate of Palaeomylus.

F: BW-3-210; may be a marginal plate of Deinodus bennetti. 

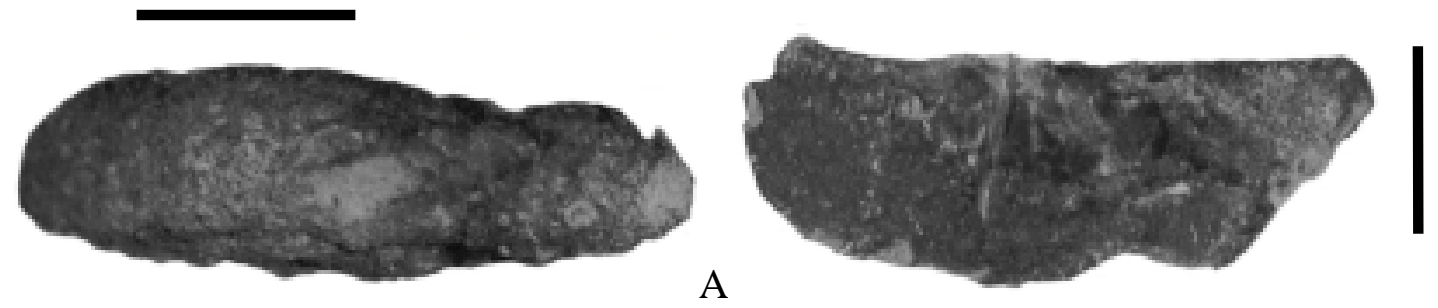

A

B
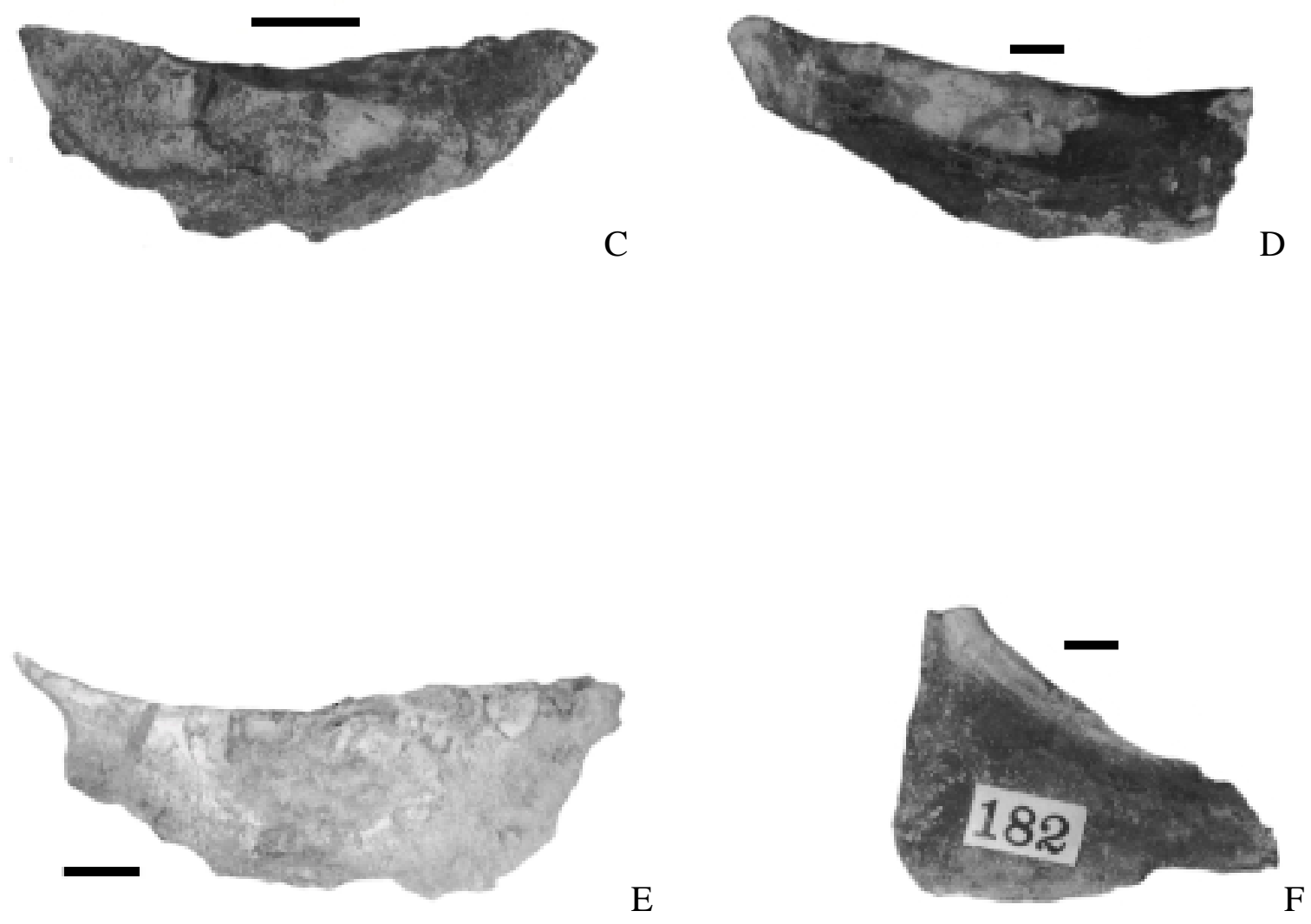
Plate 7: Deinodus bennetti Hussakof and Bryant (1919). Scale bar=1 cm

A: E18582; external view left anterior ventrolateral plate and spine.

B: E2466 showing cross-section of spine.

C: E2467 showing cross-section of mature spine.

D: E16648; spine.

E: E16646; spine.

F: E16646; close-up of spine teeth. 


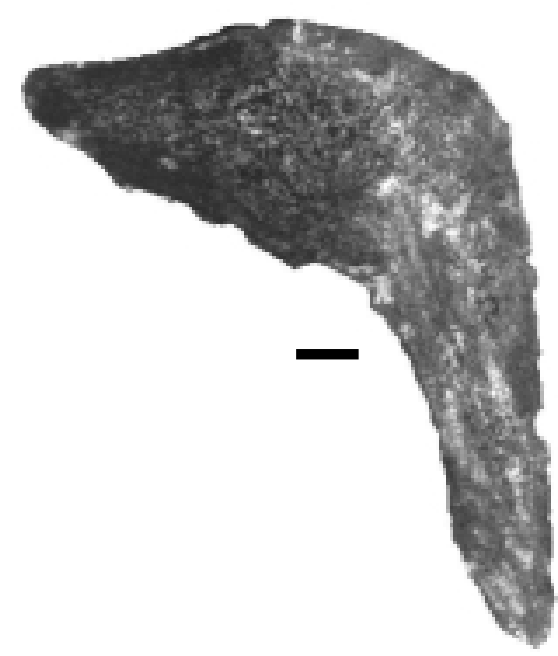

A
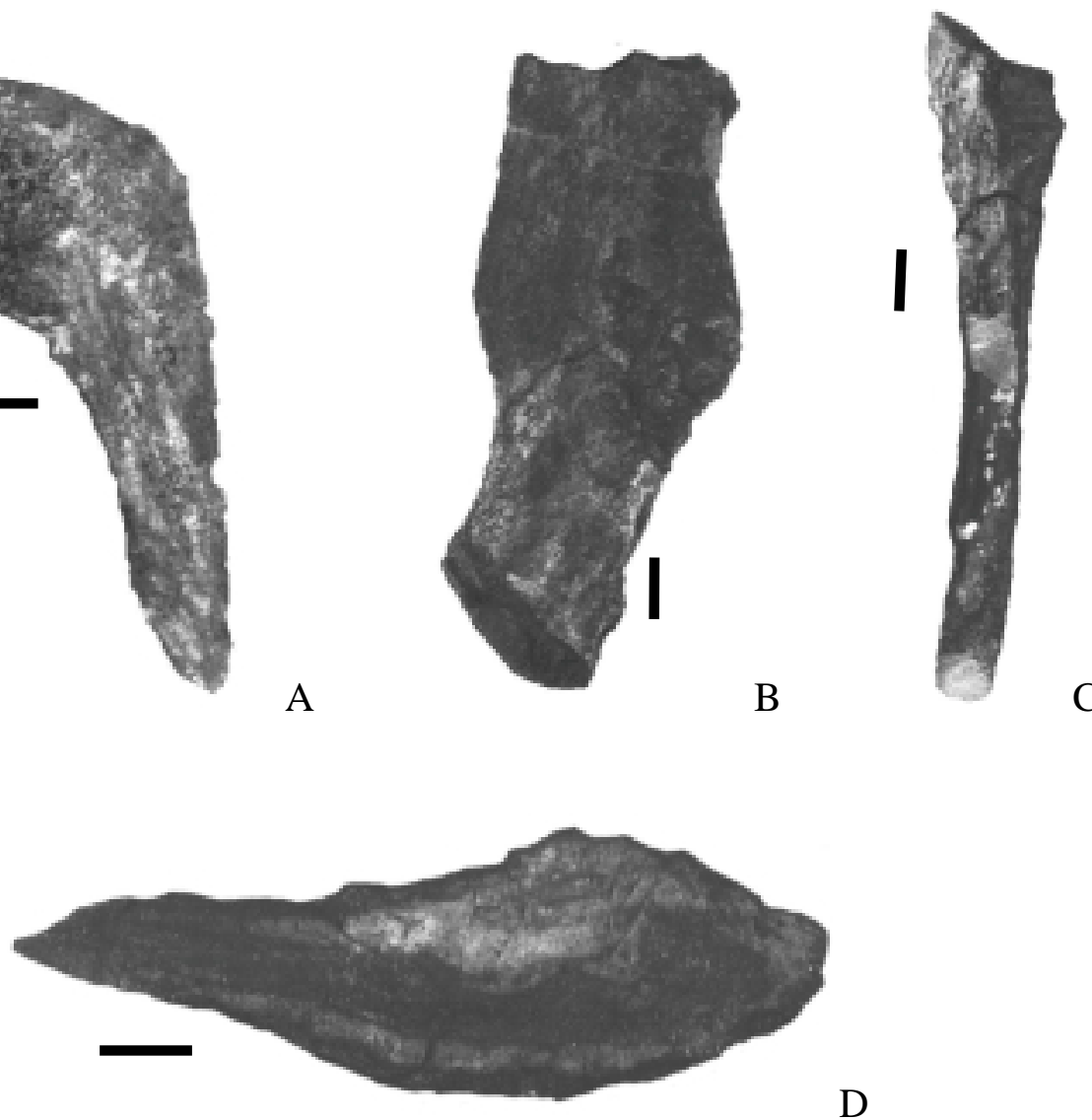

D
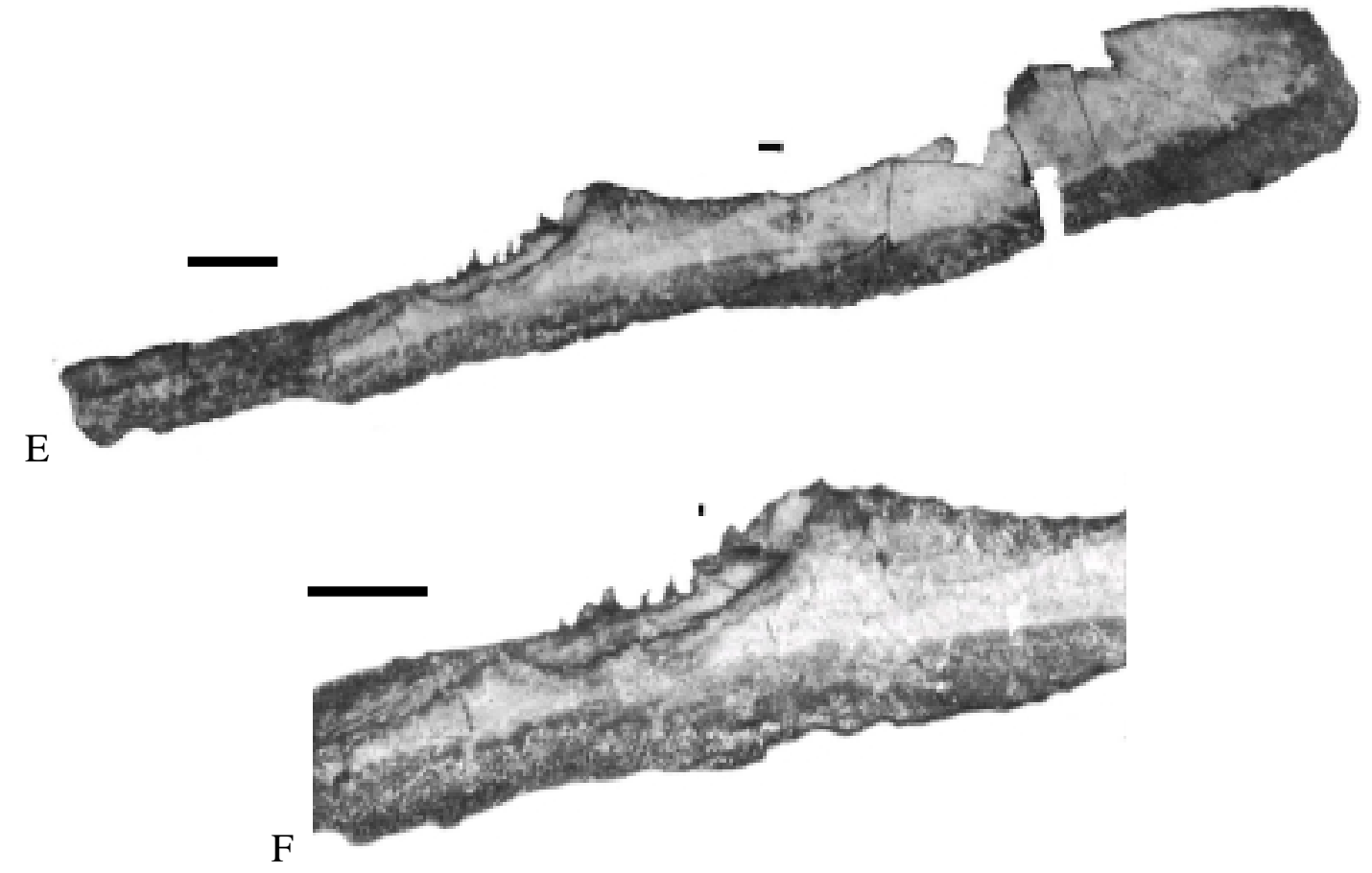
Plate 8: Deinodus bennetti Hussakof and Bryant (1919). All are interpreted as dental plates. Scale bar=1 cm.
A: E16639-labial view of a left? dental plate.
B: E16639-lingual view of a left? dental plate.
C: E1860.
D: E2471.

E: E18086.

F: E16635; left? lower? dental plate in lingual view. 

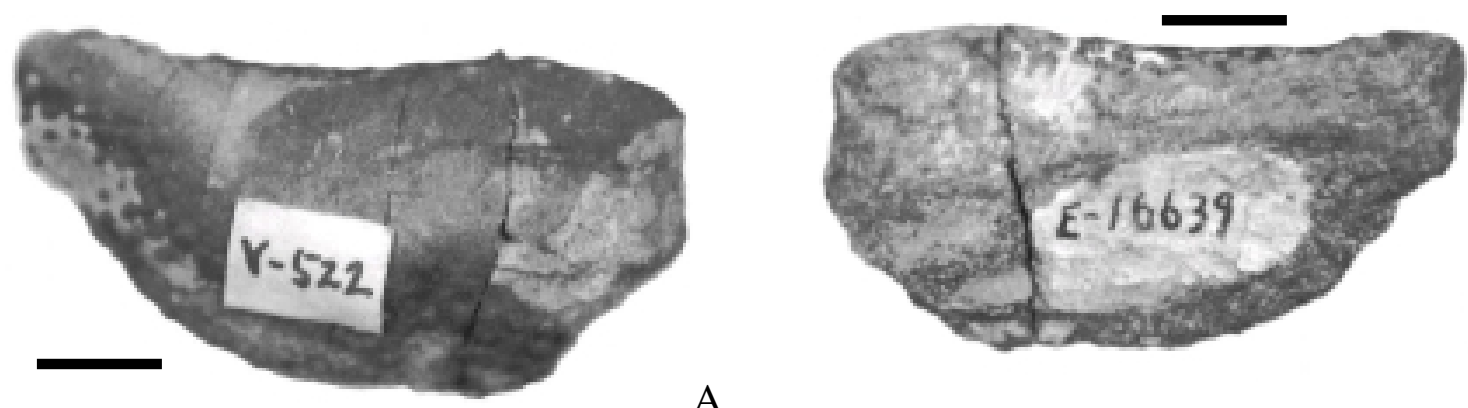

A

B
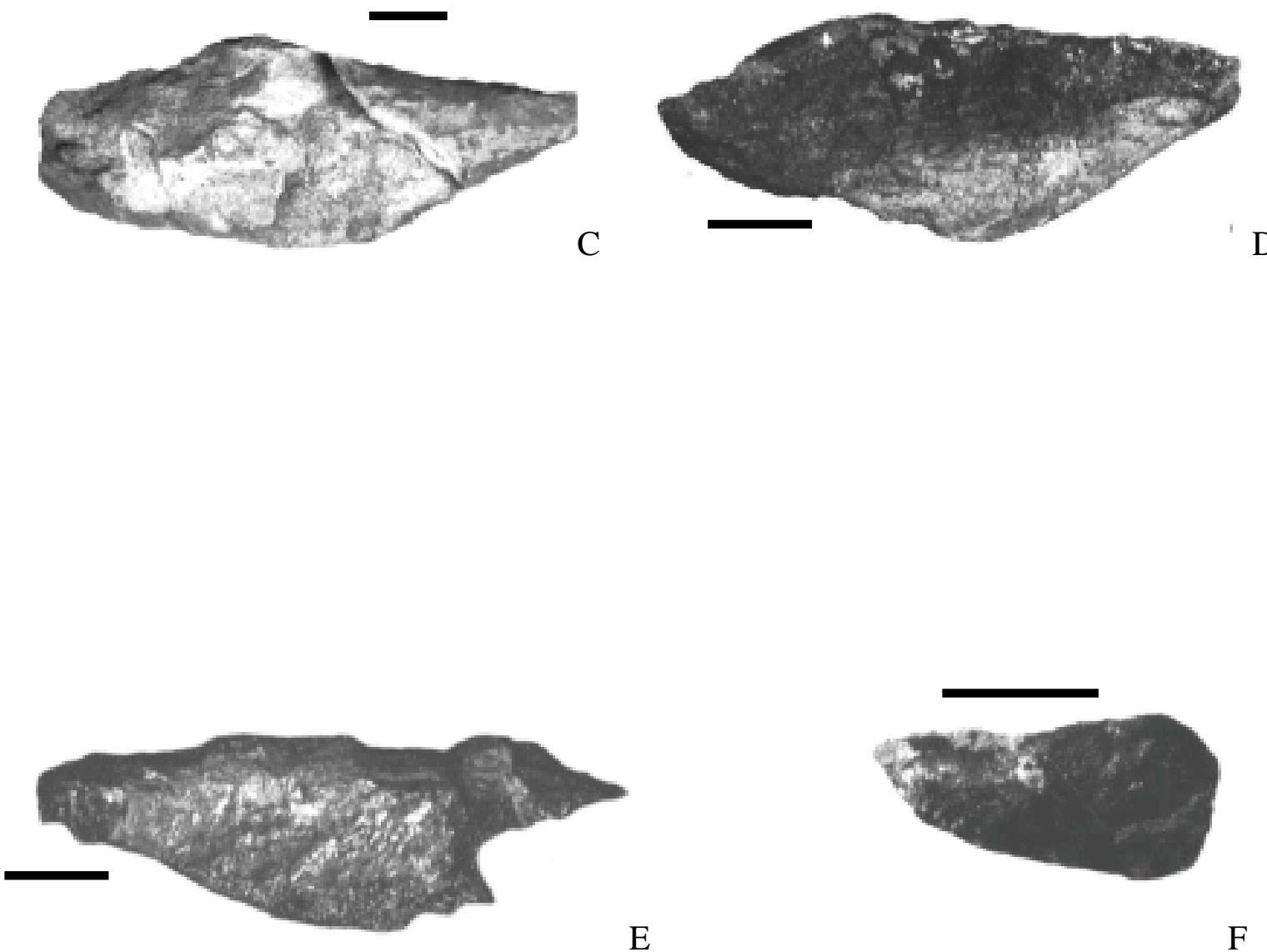

E

F 
Plate 9: Deinodus bennetti Hussakof and Bryant (1919). Scale bar=1 cm

A: E2451; a spine, possibly the dorsal spine.

B: E16556; possible anterior lateral plate.

C: E16650; portion of a spine.

D: E2465; portion of a spine.

E: E2461; a spine, possibly the dorsal spine (Hussakof and Bryant 1919; Plate 42, Figure 2).

F: E16651; portion of a spine. 

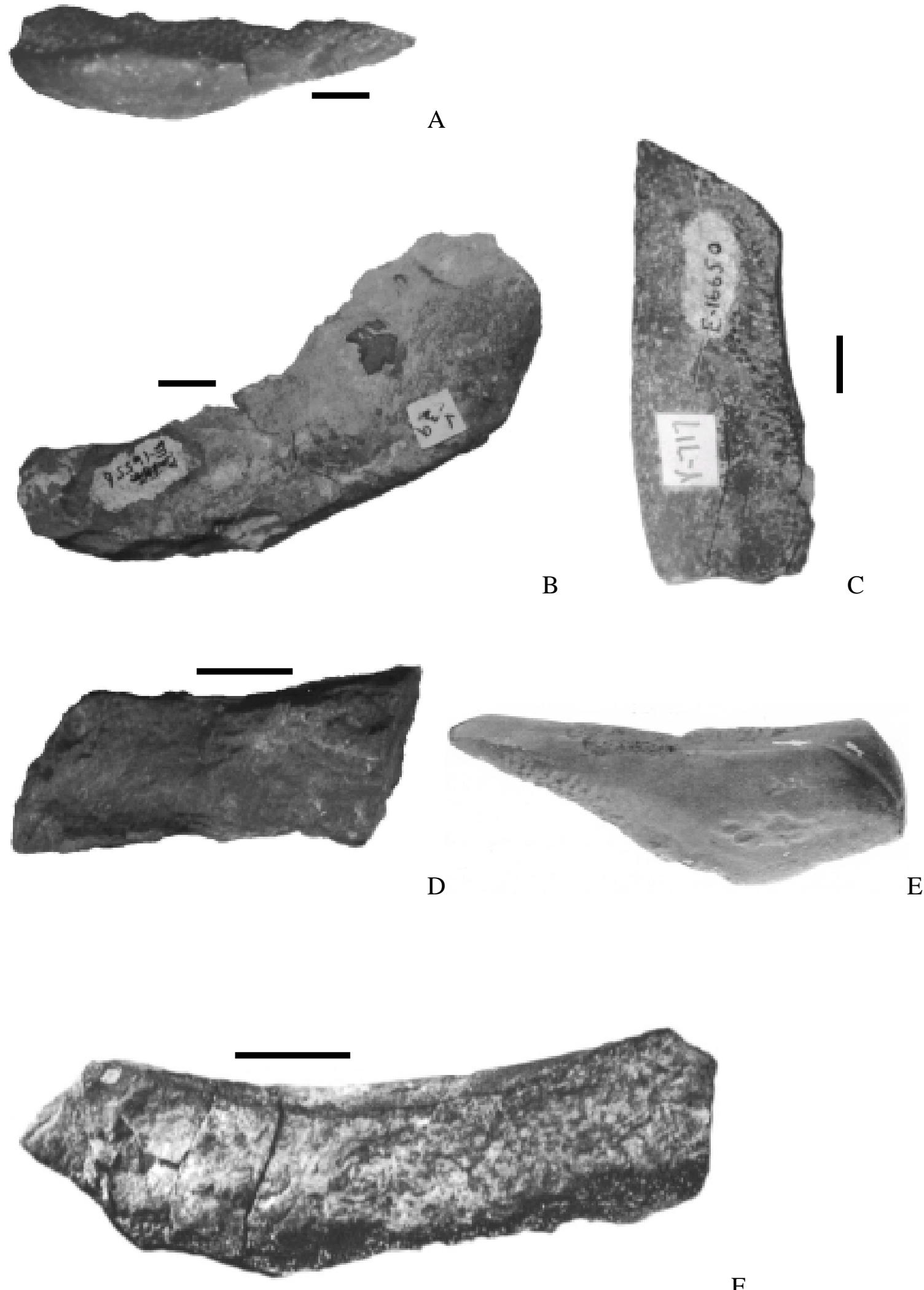
Plate 10: Deinodus bennetti, Hussakof and Bryant (1919).

E16646 shows how a spine may break apart into what appear to be other bones or plates. 


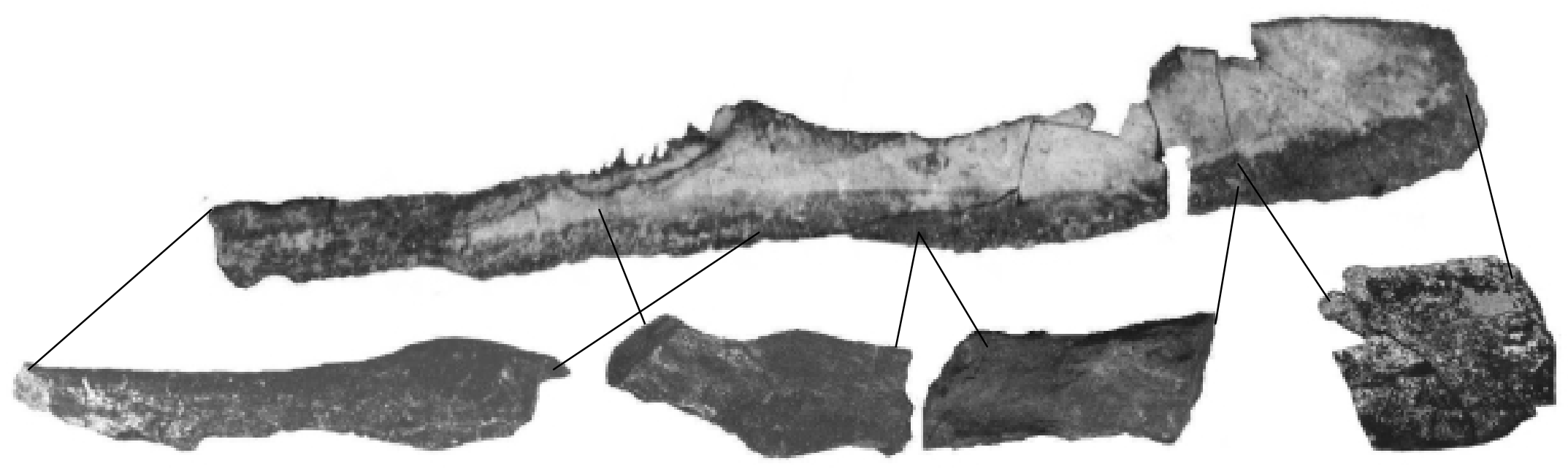


Plate 11: Deinodus bennetti Hussakof and Bryant (1919). Scale bar=1 cm

A: E16654; Unknown function, though it resembles a marginal plate.

B: E16627; Portion of a cranial plate.

C: BW-3-191; Labeled as the spurious genus, Delphinodus, though it may be a dental plate of Deinodus ohioensis.

D: BW-3-151; Labeled as the spurious genus, Delphinodus, though it may be a dental plate of Deinodus ohioensis.

E: BW-3-187; Labeled as the spurious genus, Delphinodus, though it may be a dental plate of Deinodus ohioensis.

F: BW-3-107; Labeled as the spurious genus, Pulsodus, though it may be an unknown plate of Deinodus based on the presence of characteristic tubercles.

G: BW-3-183; Labeled as the spurious genus, Pulsodus, though it may be a spine of Deinodus. 

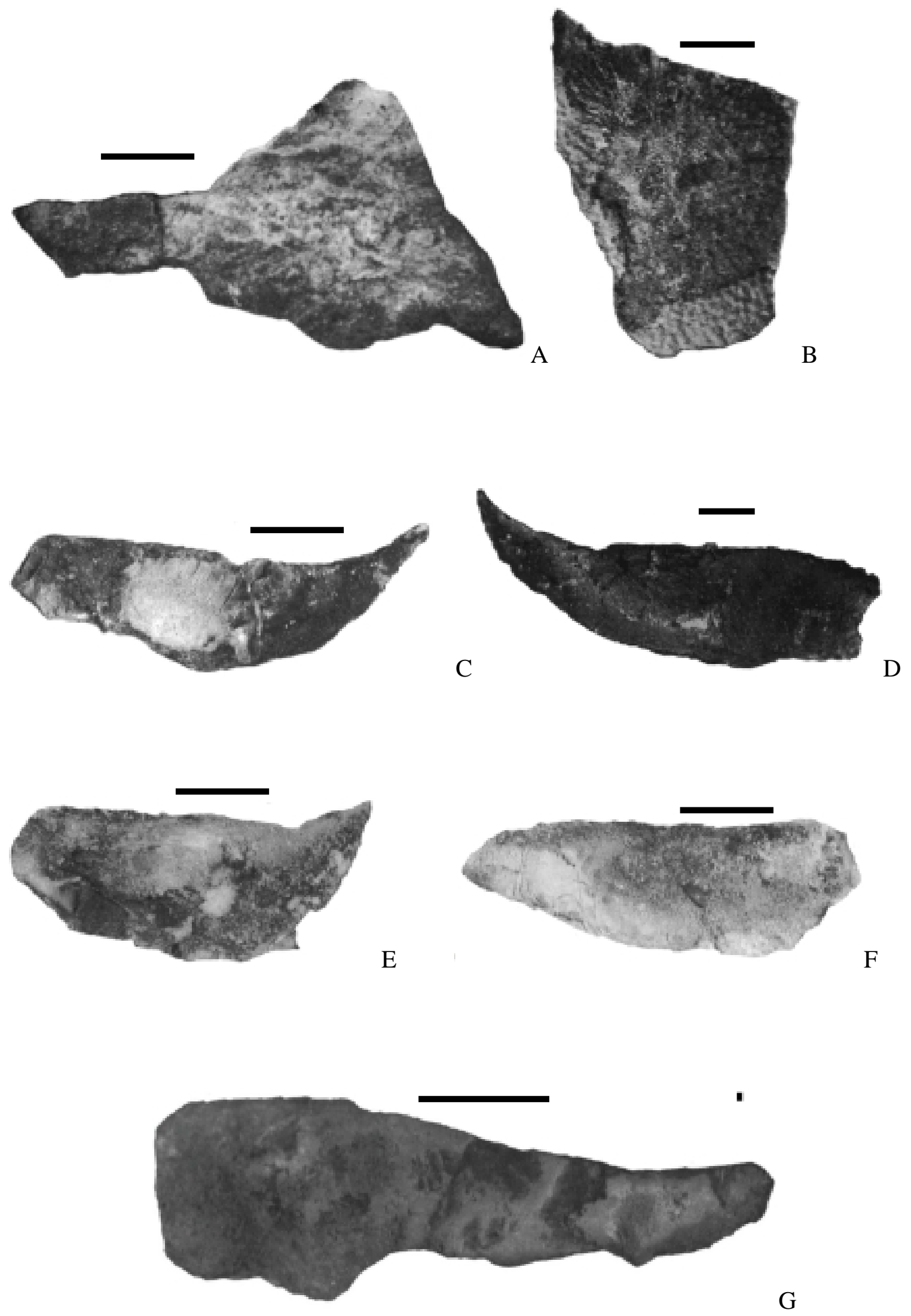
Plate 12: Deinodus bennetti Hussakof and Bryant (1919) cranium. Scale bar=1 cm.

A: Cranium from (Long, 1996; Figure 2).

B: BW-3-322; A juvenile D. bennetti cranium from the Onondaga Limestone of New York.

C: Bones of $D$. bennetti shown in 'B'. 

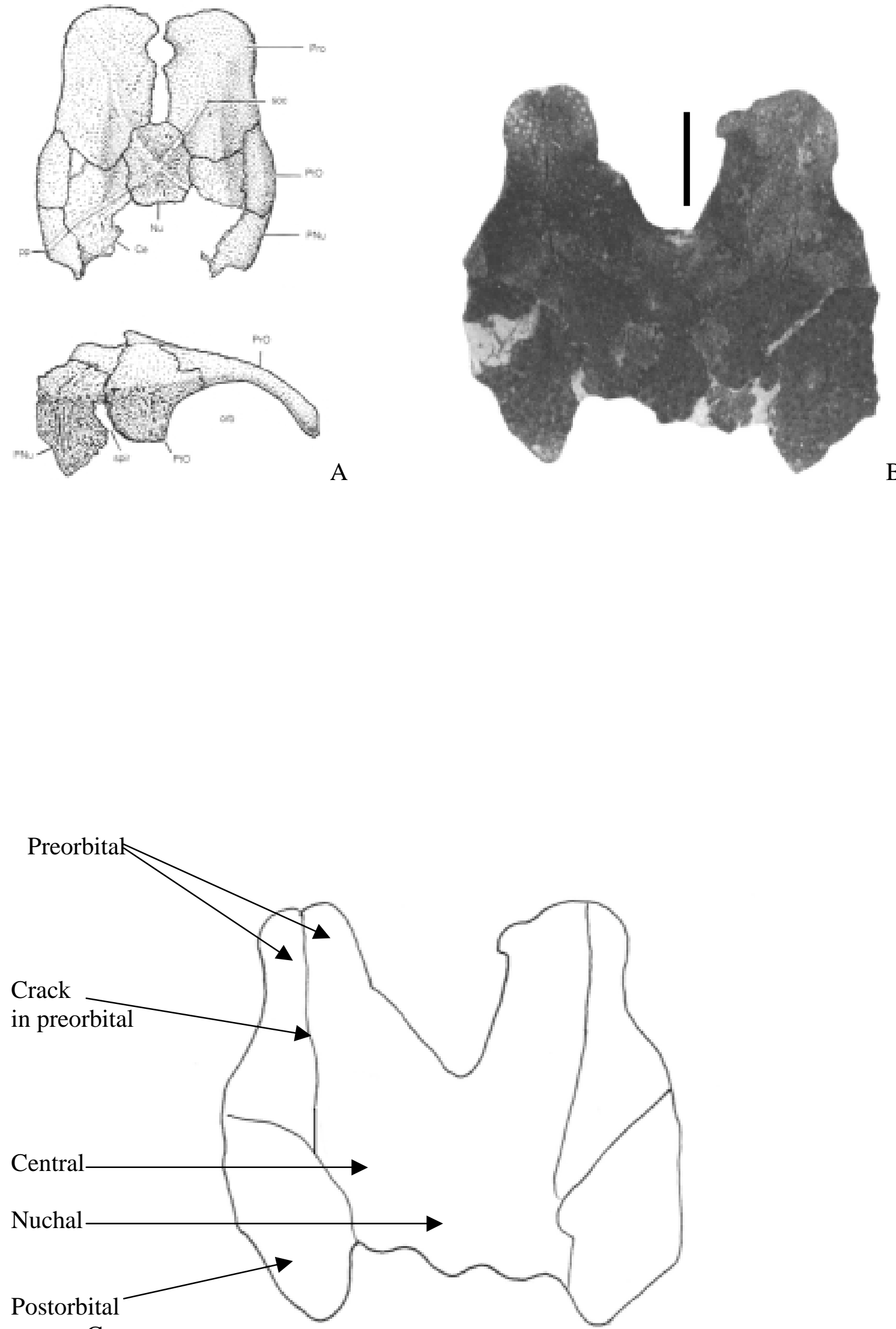

C. 
Plate 13: Deinodus ohioensis Martin (n. sp.). All represent dental plates. Scale bar=1 cm.

A: BW-3-150; lower? right dental plate.

B: BW-3-117; anterior portion of right dental plate.

C: BW-3-185

D: BW-3-405; lower? left dental plate.

E: BW-3-168; left dental plate

F: BW-3-117-whole specimen 

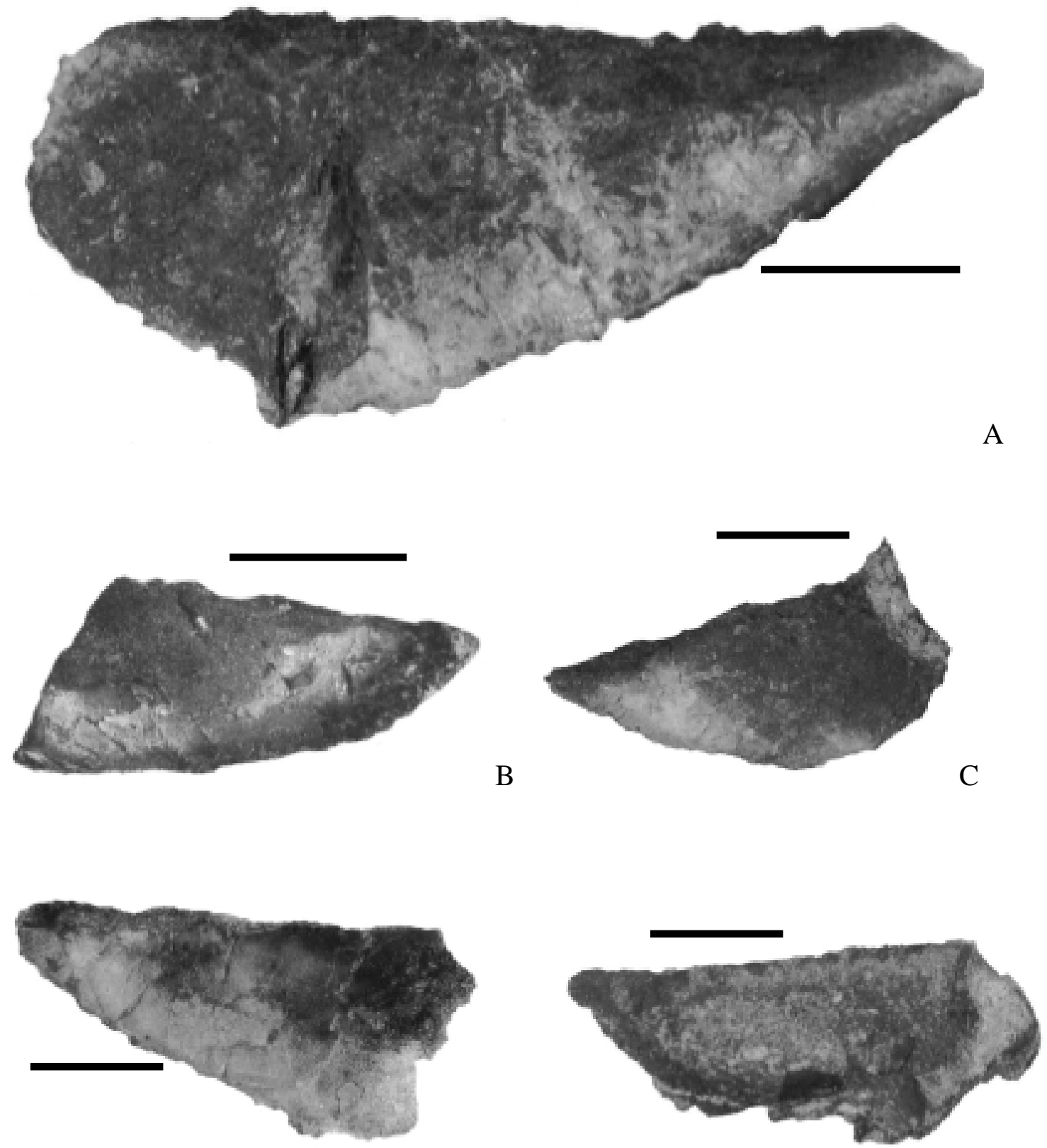

D

E

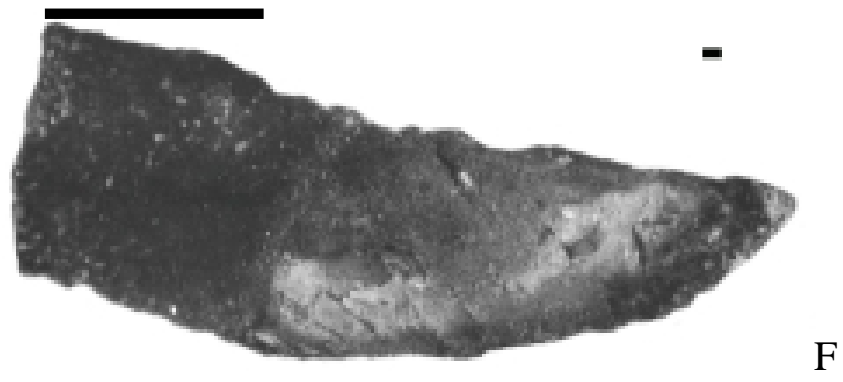


Plate 14: Eczematolepis Miller (1892). Scale bar=1cm.

A: Tubercle pattern on a Macropetalichthys anterior ventrolateral plate for comparison (OC7899).

B. BW-3-173; Submarginal? plate of Eczematolepis with a similar tubercle pattern.

C. BW-3-238; Marginal? of Eczematolepis with similar tubercles.

D. BW-3-331; Marginal? of Eczematolepis with similar tubercles.

E. BW-3-453; Marginal? of Eczematolepis with similar tubercles. 

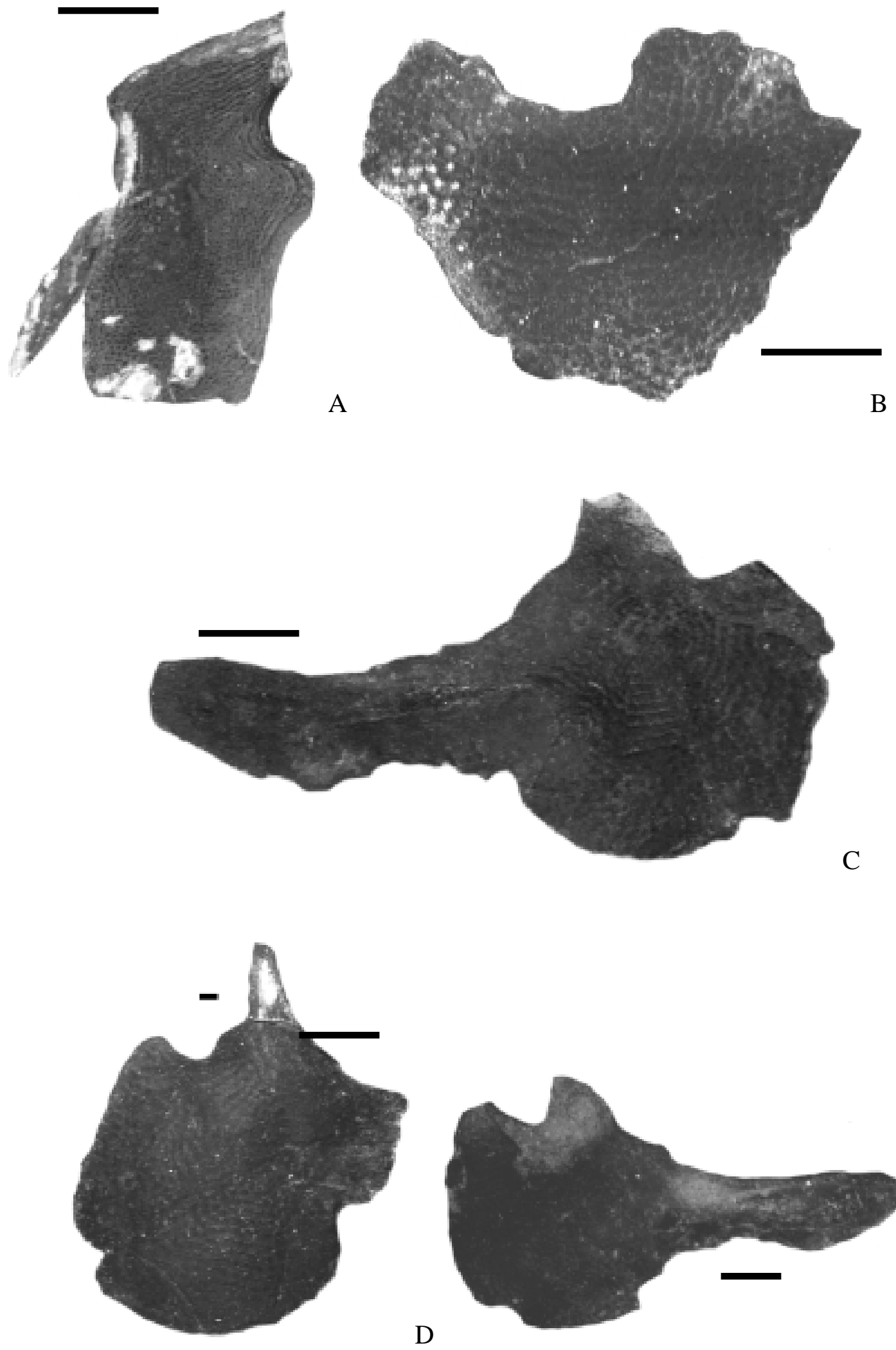

E 
Plate 15: Specimens misidentified as Asterosteus Newberry (1875). Scale bar=1 cm A: BW-3-194; anterior lateral plate of Deinodus.

B: BW-3-113; anterior lateral plate of Deinodus.

C: BW-3-103; cranial bones of Deinodus.

D: BW-3-417; cranial bones of Deinodus.

E: BW-3-376; spine of Macropetalichthys.

F. Close up of tubercles of BW-3-194 showing worn stellate pattern. 

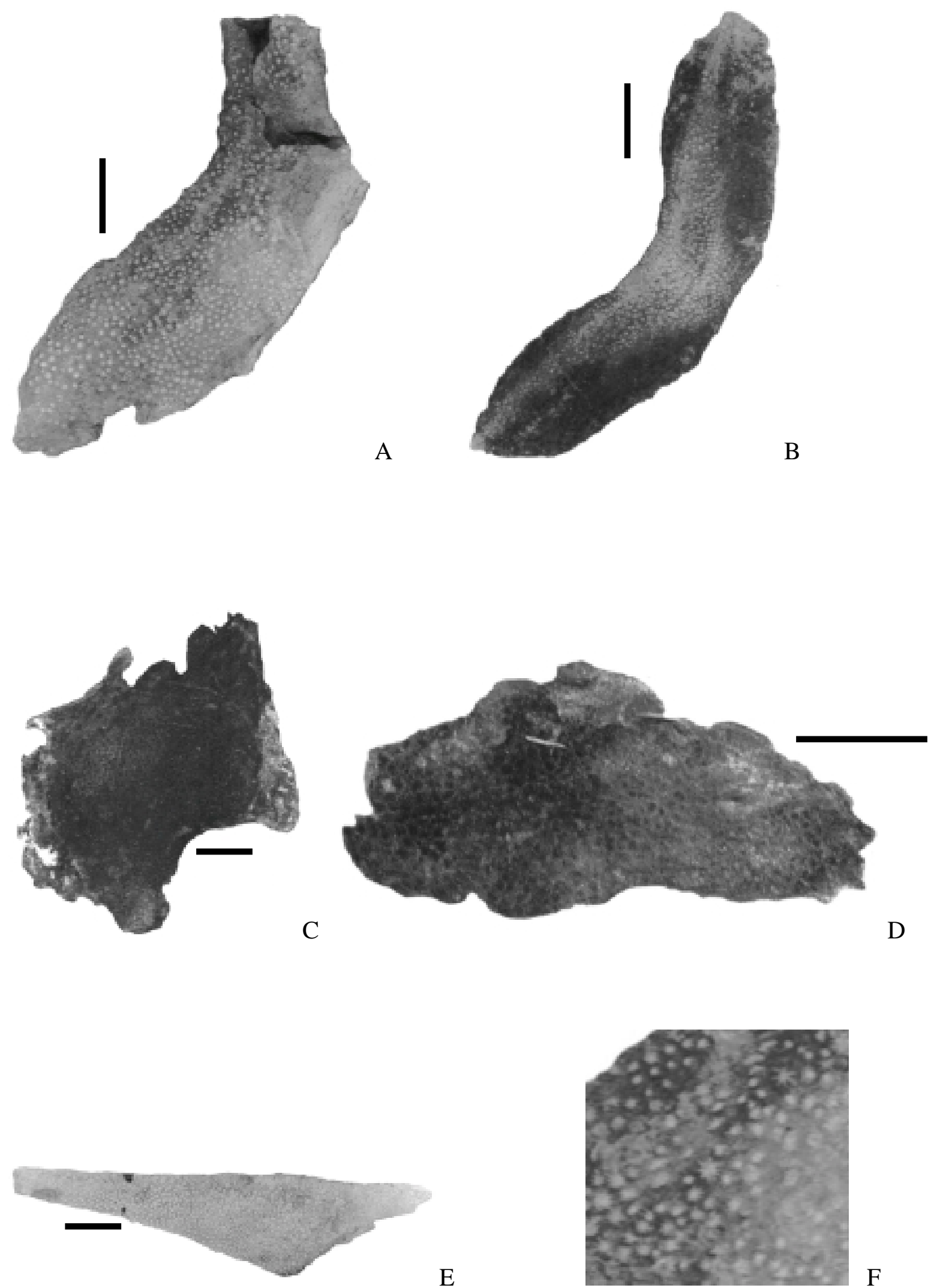
Plate 16: Machaeracanthus Newberry (1857). Scale bar=1 cm

A: E12204; ventral view of right spine.

B: E12204; dorsal view of left spine.

C: BW-3-414; clavicle.

D: BW-3-95; tooth whorl.

E: BW-3-149; dental plate fragment. 

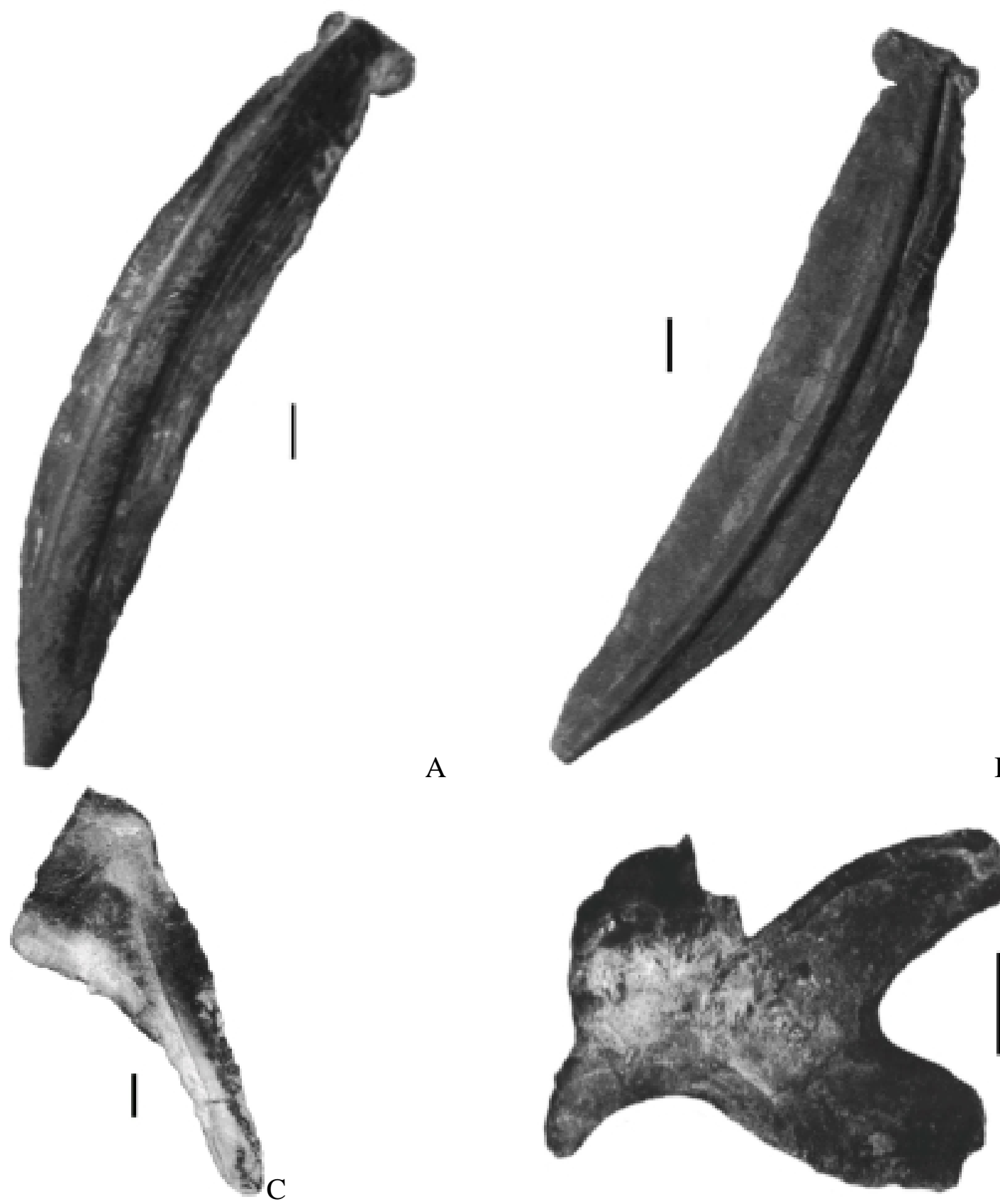

A

B
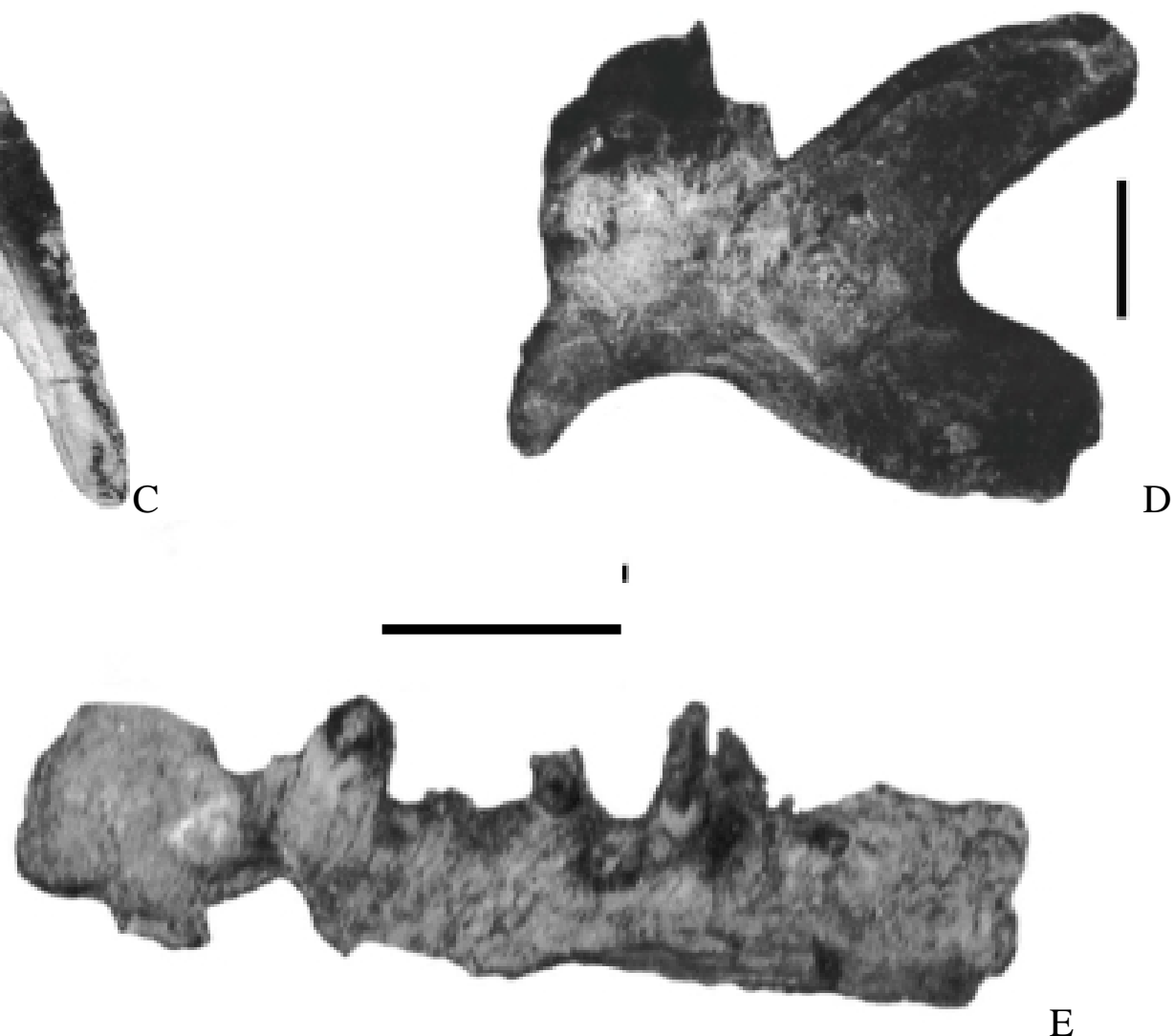
Plate 17: Onychodus sigmoides Newberry (1857).

A: Reconstruction of the Australian form (Long, 2001; Figure 1).

B: Right parietal, dorsal view (BW-3-362).

C: Left parietal, dorsal view (BW-3-410). 

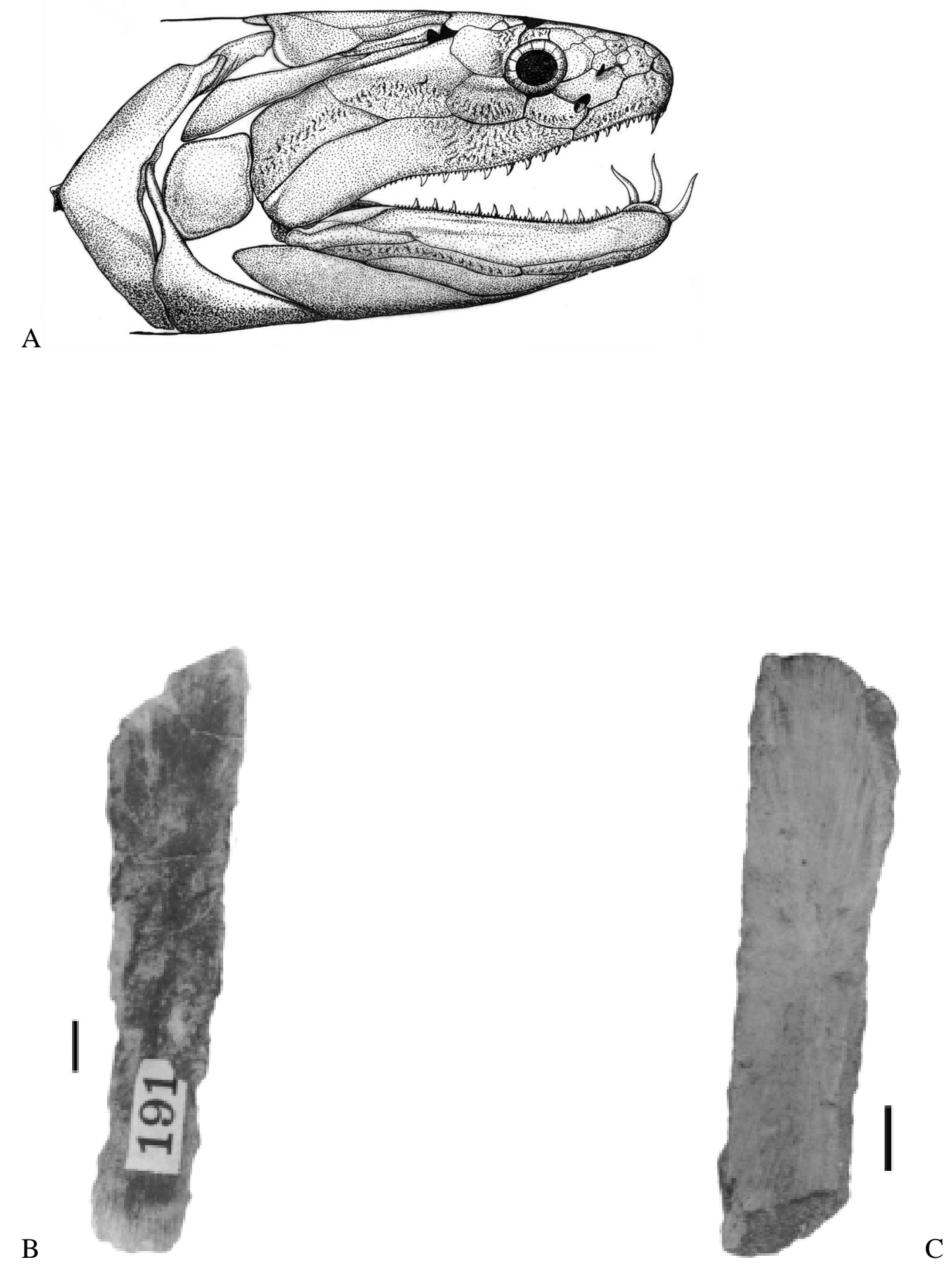
Plate 18: Onychodus sigmoides Newberry (1857). Scale bar=1 cm A: BW-3-276; resembles an opercle bone.

B: BW-3-252; resembles an opercle bone.

C: BW-3-184; resembles an opercle bone.

D: BW-3-325; resembles a pectoral girdle bone.

E: BW-3-368; resembles a pectoral girdle bone.

F: BW-3-361; resembles a pectoral girdle bone. 


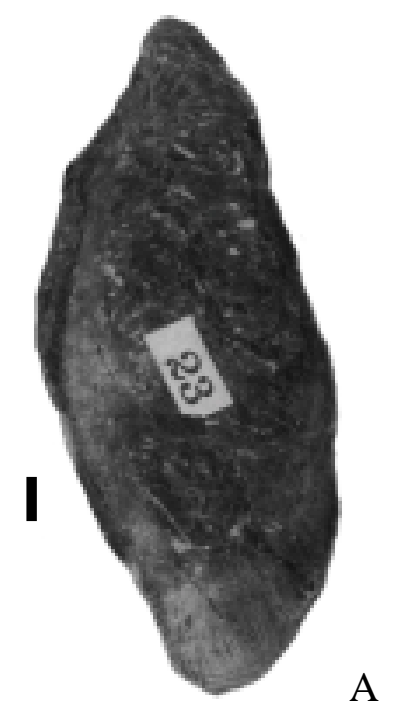

A

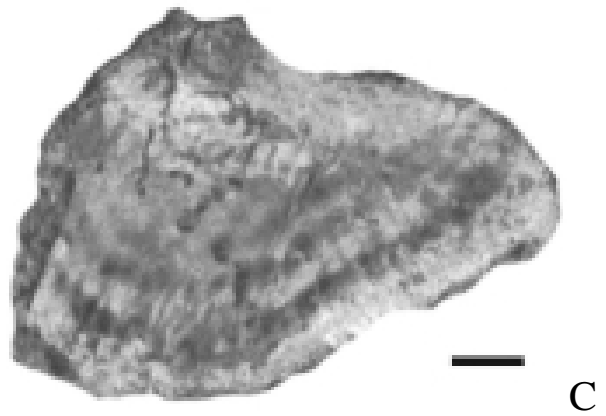

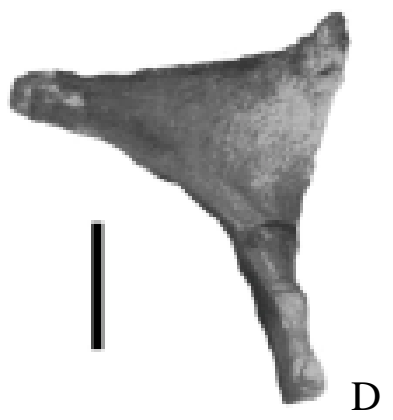

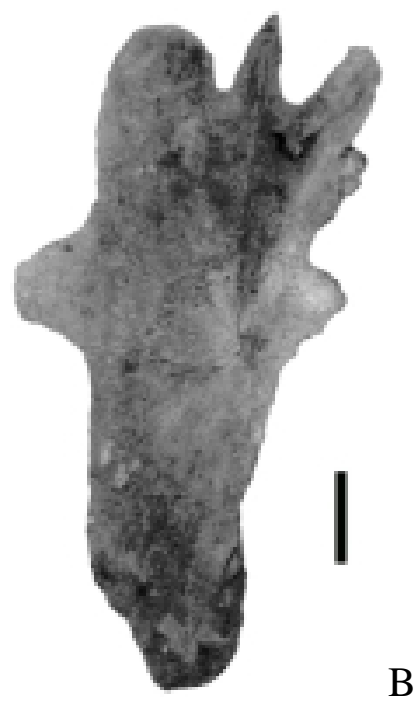

B

D
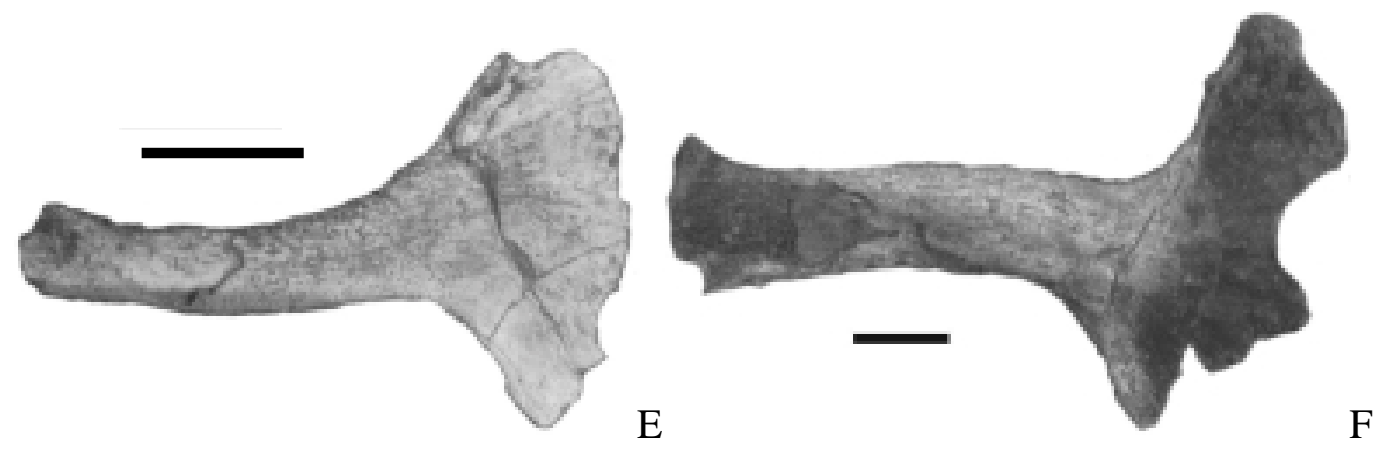
Plate 19: Onychodus sigmoides Newberry (1857). Scale bar=1 cm A: BW-3-372; a left subopercle bone.

B: BW-3-452; bone is unknown.

$\mathrm{C}$ : BW-3-462; bone is unknown.

D: BW-3-498; an unknown ptyctodont plate labeled, Onychodus.

E: Tooth whorl (from Newberry, 1873).

F: Left jaw (from Newberry, 1873). 

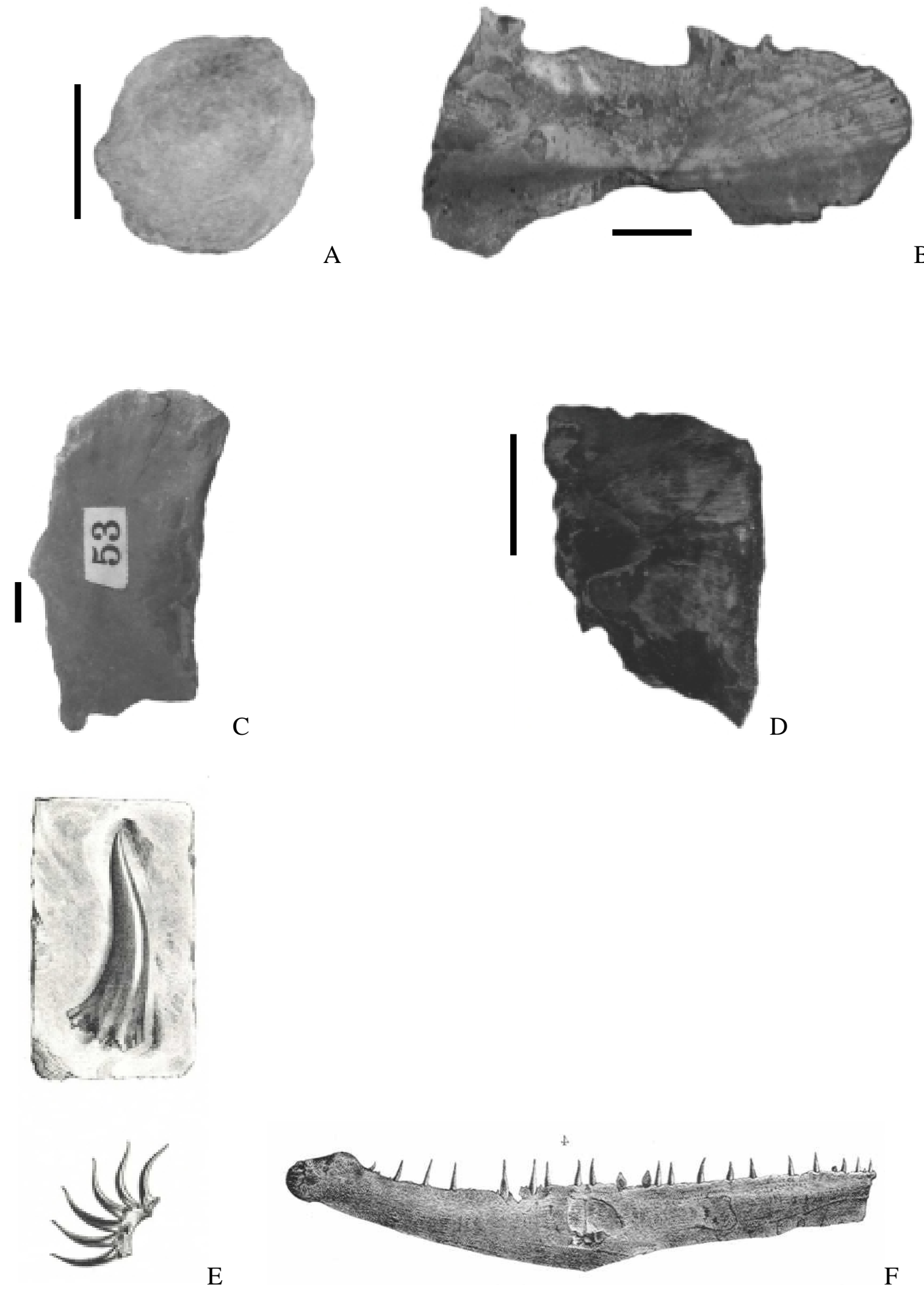

E 
Plate 20: Unknown or previously identified incorrect genera.

A: BW-3-171; Asperichthys; probably a spine of some ptyctodont.

B: BW-3-361; Stenoichthys; probably the cleithrum of Onychodus.

C: BW-3-111; Secansodus; spine of a ptyctodont.

D: BW-3-107; Pulsodus; may be a dental element of Deinodus.

E: BW-3-199; Asperichthys; a plate of Eczematolepis.

F: BW-3-232; Cavagnathus; anterior lateral plate of a ptyctodont.

G: BW-3-206; Coultraotus delicatus; ptyctodus dental plate.

H: BW-3-183; Pulsodus; may be a spine of Deinodus.

I: BW-3-342; Secansodus; dental element of Rhynchodus.

J: BW-3-328; Secansodus; dental element of Ptyctodus.

K: BW-3-96; Secansodus; dental element of Ptyctodus. 

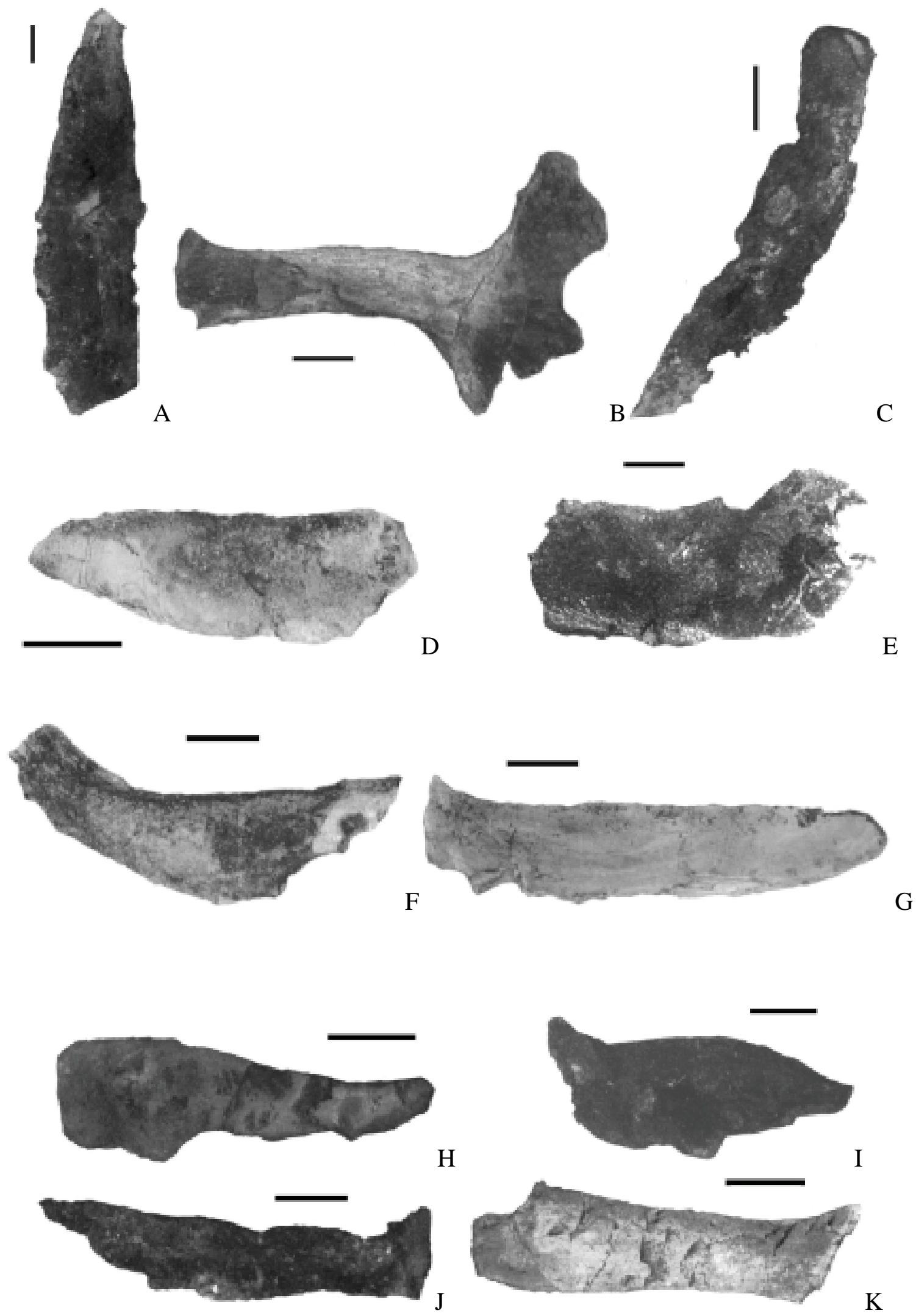
Plate 21: Previously unidentified specimens.

A: BW-3-474: dental plate of Rhynchodus.

B: BW-3-31: dental plate of Rhynchodus.

C: BW-3-366; portions of Machaeracanthus spines.

D: BW-3-360c; portions of Machaeracanthus spines.

E: Submarginal plate from Long (1996).

F: BW-3-11471; submarginal plate of an unknown ptyctodont incorrectly labeled as a Rhynchodus dental element.

G: BW-3-390; anterior ventrolateral plate and spine of Macropetalichthys.

H: BW-3-454; anterior ventrolateral plate and spine of Macropetalichthys.

I: BW-3-456; anterior ventrolateral plate and spine of Macropetalichthys?.

J: BW-3-412; anterior ventrolateral plate and spine of Macropetalichthys?. 

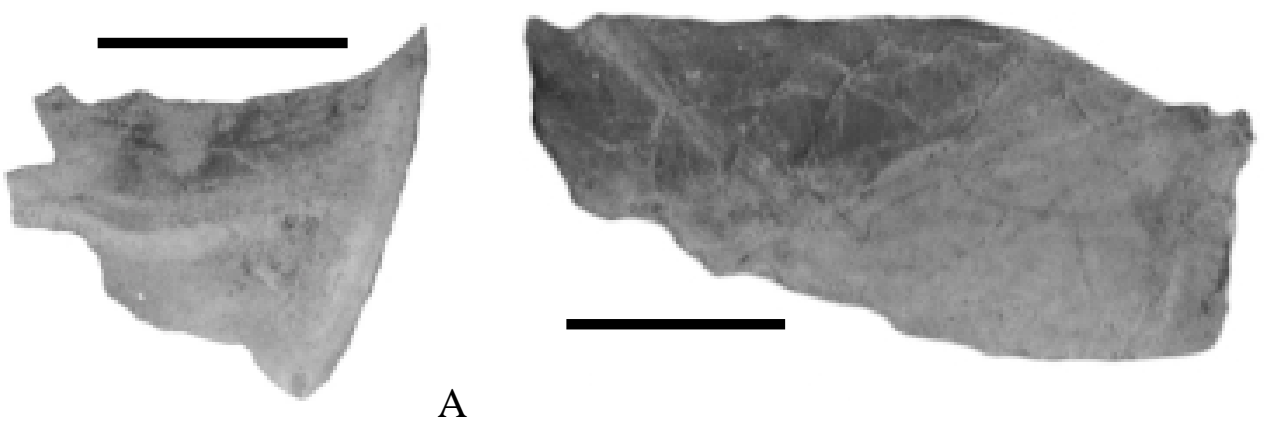

A

B
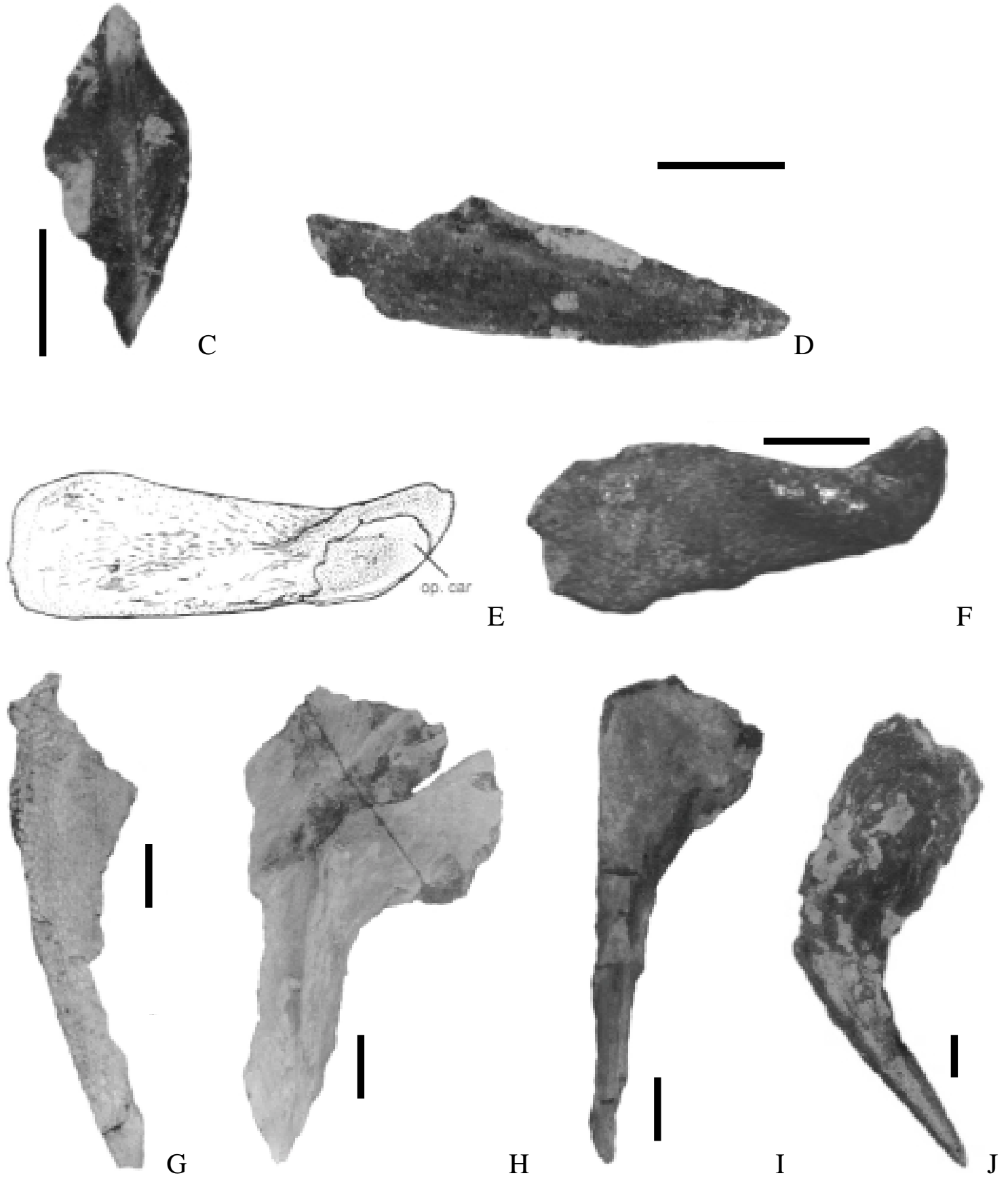
Plate 22: Previously unidentified specimens. Scale bar=1 cm.

A: BW-3-468a; probably the anterior lateral plate of a ptyctodont.

B: BW-3-447b; probably the spine of a ptyctodont.

C: BW-3-240; probably the dental plate of a ptyctodont.

D: BW-3-468b; spine of Deinodus bennetti. 

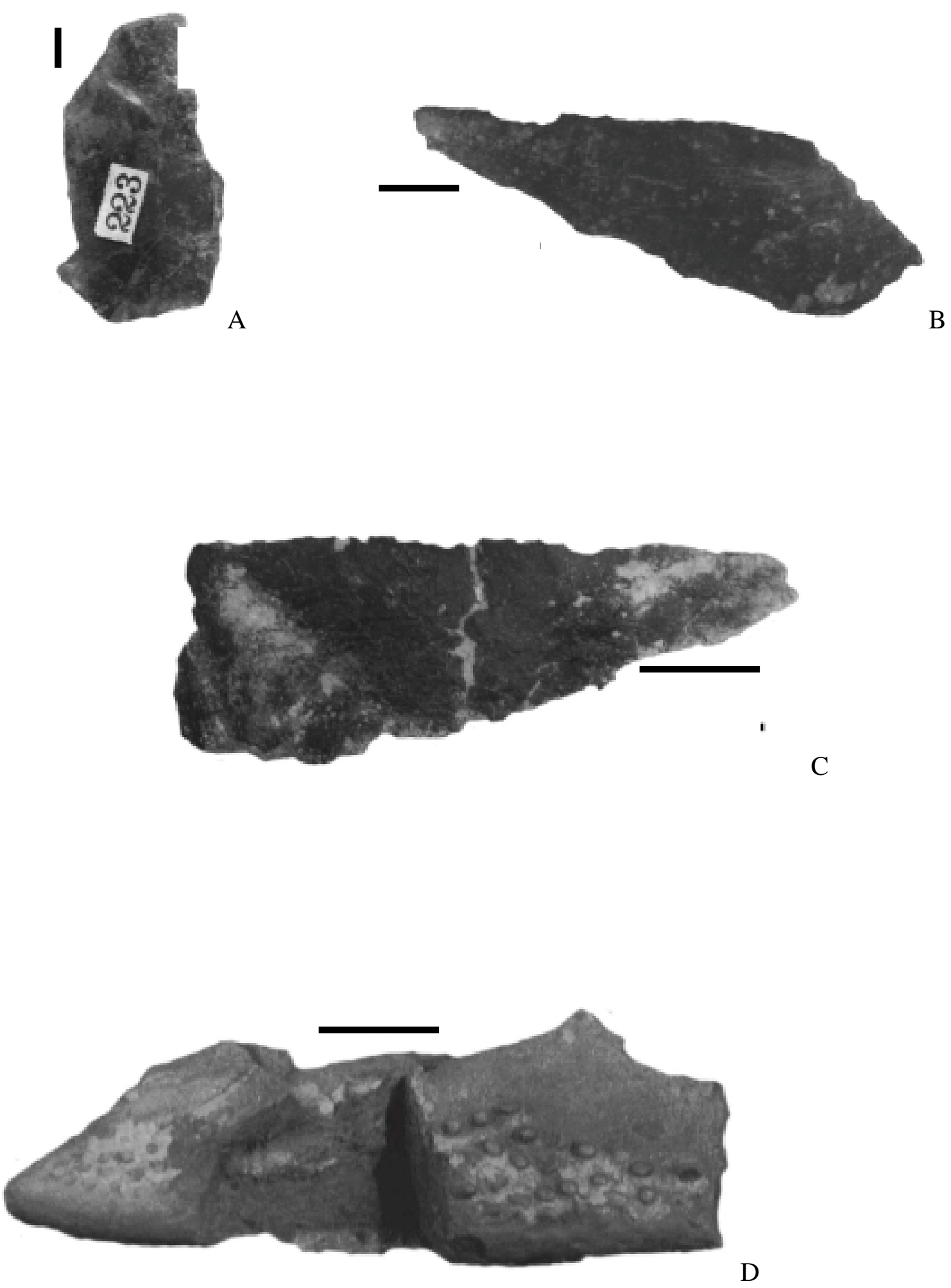
Plate 23: Previously unidentified specimens; All are identified as the submarginal plates of an unknown ptyctodont. Scale bar=1 cm.
A: BW-3-377.
B: BW-3-345.
C: BW-3-453.
D: $\mathrm{BW}-3-355$.
E: BW-3-451.
F: BW-3-306. 

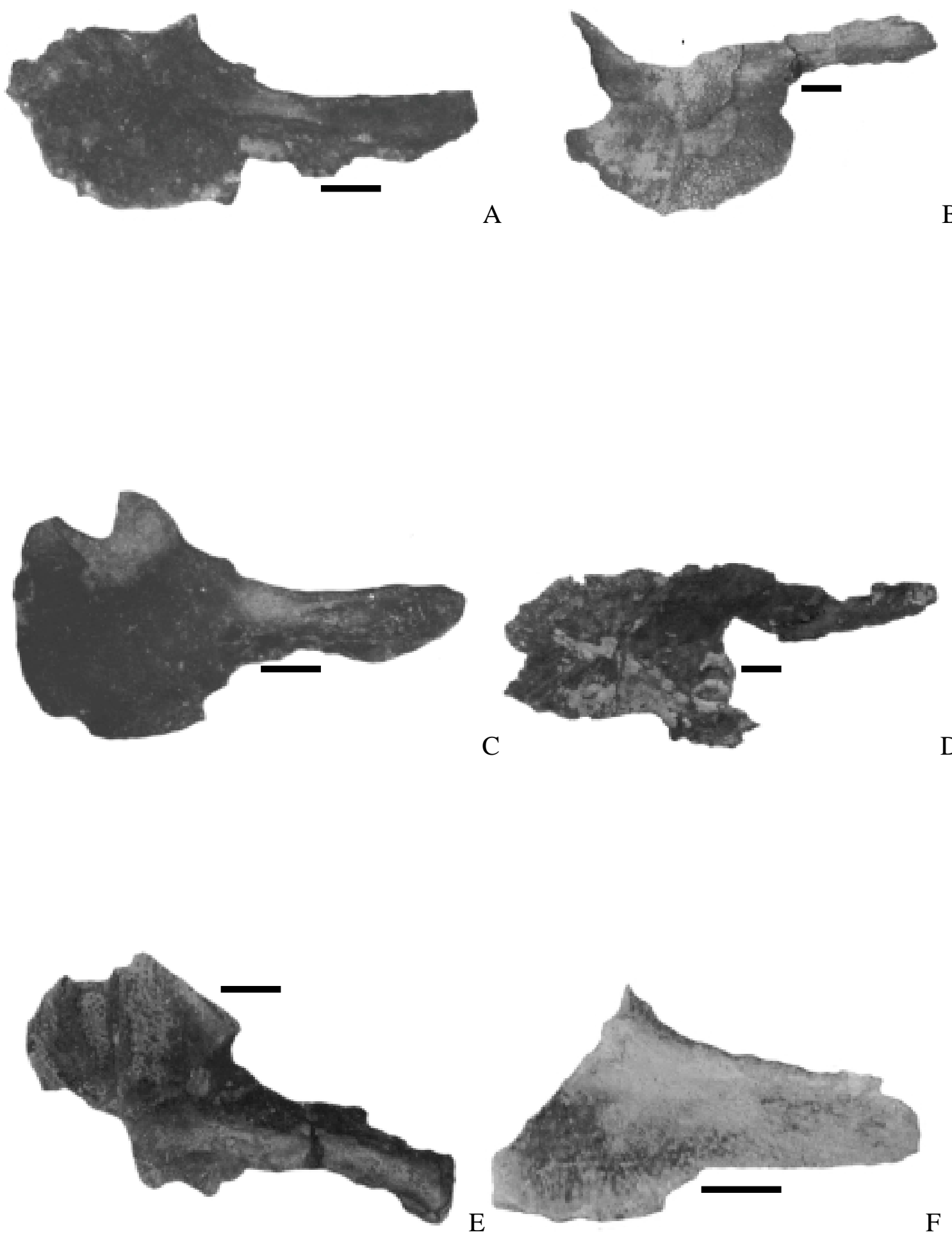
Plate 24: Previously unidentified specimens. Scale bar=1 cm.

A: E18094; may be the anterior lateral plate of a juvenile Deinodus bennetti.

B: E22102; portion of a Macropetalichthys spine.

C: E18115; portion of a Macropetalichthys spine.

D: E18440; tooth of Onychodus.

E: E17940; dental plate of a juvenile Ptyctodus.

F: E18223; upper? right? dental plate of a juvenile Palaeomylus.

G: E22106; plate of Macropetalichthys?. 

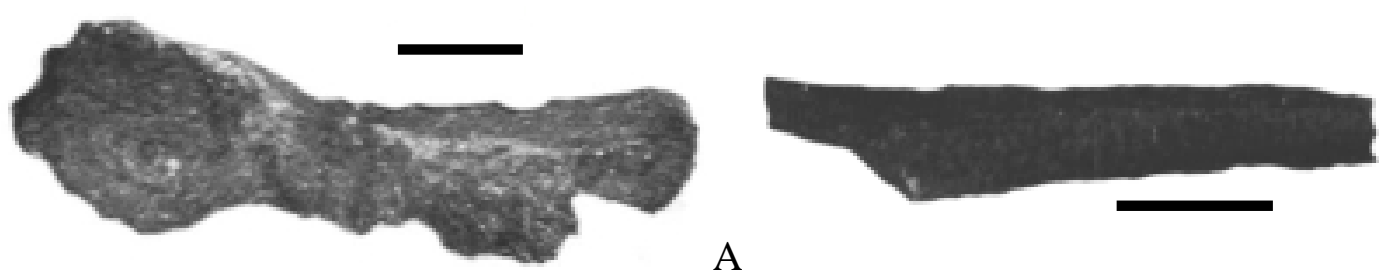

A

B
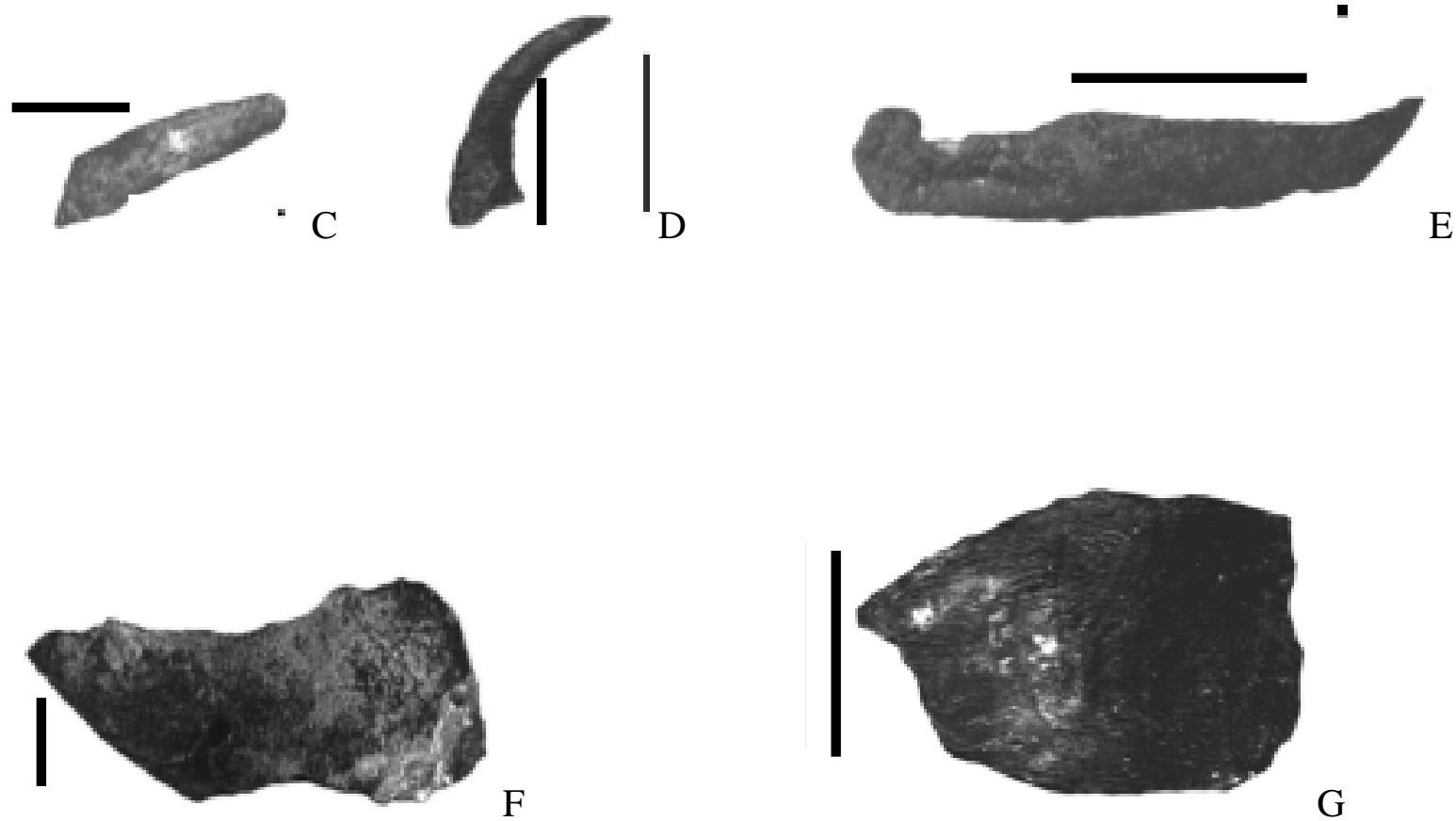
Plate 25: Previously unidentified specimens. Scale bar $=1 \mathrm{~cm}$.
A: E18106; spine of Deinodus bennetti.
B: E18112; anterior ventrolateral plate of Deinodus bennetti.
C: E18087; dental plate of Deinodus bennetti.
D: E18095; unknown plate of Deinodus bennetti.
E: E18102; unknown plate of Deinodus bennetti.
F: E18389; may be the interohyal of Deinodus bennetti. 


$$
20
$$


Appendix 1: Catalog of taxa reported from the Onondaga. Members are not delineated. Data from Baschnagel (1942), Dutro (1981),

Feldman (1980), Hoare (1989), House (1962), Jenkins (1979), McGregor (1979), New York Geological Society (1931), Oliver and Sorauf (1983),

Oliver (1956b, 1958), Richardson (1950) and Rickard (1981)

\section{Corals}

Acervularia sp.

Acinophyllum mclareni

Acinophyllum seregatum

Acrophyllum oneidaense

Amplexiphyllum

Amplexiphyllum cf. hamiltoniae

Aulacophyllum sp.

Aulopora

Breviphrentis sp.

Ceratopora (=Aulocystis)

cf. Amplexiphullum

cf. Syringaxon

Coenites

Cyathocylindrium opulens

Cyathocylindrium $\mathrm{sp}$.

Cyathophyllum robustum

Cylindrophylum deearium

Cystiphylloides americanum

Disphyllum stummi

Emmonsia

Eridophyllum aulodokum

Eridophyllum corniculum

Eridophyllum seriale

Favosites

Favosites basalticus

Favosites emmonsi

Favosites epidermatus

Favosites hemisphericus

Guerichiphyluum sp. cf. echoense

Hadrophyllum orbignyi

\section{Brachiopods}

Acrospirifer duodenaria

Ambocoelia umbonata
Heliophyllum

Heliophyllum cf. proliferum

Heliophyllum halli

Heterophrentis davisana

Heterophrentis sp.

Kionelasma mammiferum

Lecfedites

Lecfedites canadensis

Metiophyllum exiguum

Metiophyllum exiguum var. elongatum

Phillipsastraea sp.

Prismatiophyllum conjunctum

Prismatiophyllum sp.

Prismatiophyllum truncata

Prismatophyllum ovoideum

Romingera

Siphonophrentis gigantea

Siphonophyrentis cf. halli

Stereolasma linneyi

Stereolasma ungulum

Synaptophyllum arundinaceum

Synaptophyllum kladion

Syringipora

Zaphrentis corniculum

Zaphrentis gigantea

Zaphrentis prolifica

\section{Crinoids}

Arachnocrinus bulbosus

Craterocrinus ruedemanni

Dolatocrinus speciosus

Leptostrophia perplana

Levenea lenticularis

Levenea sp. A

\section{Cephalopods}

Agoniatites vanuxem

Agoniatites vanuxemi floweri

Agoniatites vanuxemi intermedius

Agoniatites vanuxemi nodiferus

Agoniatites vanuxemi vanuxemi

Cabrieroceras plebeiforme

Cyrtoceras eugenium

Dawsonoceras thoas

Foordites buttsi

Gyroceras (Halloceras) paucinodum

Gyroceras matheri

Gyroceras undulatum

Gyrocerass (Rhyticeras) trivolve

Holzapfeloceras croyi

Orthoceras pelops

Orthoceras thoas

Orthoceras zeus

Parodiceras discoiduem

Poterioceras examium

Subanarcestes cf. macromphalus

Tornoceras buttsi

Tornoceras cf. buttsi

Tornoceras mithrax

Trochoceras clio

Trochoceras eugenium

\section{Sponges}

Astraeospongia claua

Astraeospongia onodagae

\section{Miospores}

Acinoporites lindlarensis

Acinosporites macrospinosus

\section{Pelecypods}

Aviculopecten parilis

Conocardium cuneus

Goniophora perangulata

Lyriopecten dardanus

Megambonia cardiformis

Panenka dichotoma

Plethomytilus ponderosa

\section{Gastropods}

Bellerophon pelops

Diaphorostoma lineatum

Ecculiomphalus

Euomphalus decewi

Liospira?

Phanerotinus laxus

Platyceras dumosum

Platyceras symmetricum

Platyceras undatum

Pleurotomaria arata

Pleurotomaria decewi

Straparollus

\section{Algae (Diatoms)}

"Ceratium"

Chroococcaceae

Desmidiaceae

Nostocaceae

Oocystaceae

Ulotrichaceae

\section{Trilobites}

Calymene platys

Dalmanites anchiops 
Amphigenia elongata Athyris reticularis

Athyris sp. A

Athyris spinosa

Athyris spiriferoides

Atrypa impressa

Atrypa reticularis

Camarotoechia? limitare

Centronella glansfagea

Charionella scitula

Charionoides aff. doris

Charionoides doris

Chonetes deflectus

Chonetes hemisphericus

Chonetes lineatus

Chonetes sp.

Chonostrophia reversa

Coelospira camilla

Costistrophonella ampla

Cupularostrum sp. A

Cyrtina hamiltonensis

Dalejina sp. A

Delthyris raricostata

Duryeella macra

Elytha fimbriata

Fimbrispirifer divaricatus

Fimbrispirifer grieri

Gypidula sp.

Isorthis propinqua

Kayserella? sp.

Lavenea sp. A

Leptaena aff. rhomboidalis
Levenea sp. B

Longispina mucronata

Mediospirifer manni

Megakozlowskiella raricosta

Megastrophia hemisphaerica

Megastrophia sp.

Meristella nasuta

Nucleospira aff. ventricosa

Nucleospira concinna

Pacificocoelia acutiplicata

Paraspirifer acuminatus

Pentagonia unisulcata

Pentamerella arata

Protoleptostrophia perplana

Rhipidomella alsa

Schizophoria cf. multistriata

Schuchertella? pandora

Spinatrypa spinosa

Spinulicosta navicella

Spirifer acuminatus

Spirifer divaricatus

Spirifer duodenarius

Spirifer varicosus

Stropheodonta demissa

Stropheodonta hemispherica

Stropheonella cf. punctulifera

Strophonella ampla

Trematospira sp.

Truncalosia truncata

Tentaculitiods

Tentaculites scalariformis
Anapiculatisporites petilus

Ancyrospora ancyrea

Ancyrospora eurypterota/?eurypterota

Apiculatisporis microconus

Apiculiretusispora plicata

Calyptosporites proteus

Corystisporites multispinosis

Densosporites devonicu/orcadensis

Dibolisporites echinaceus

Dibolisporites eifeliensis

Emphanisporites annulatus

Grandispora douglastownense

Grandispora mammillata

Grandispora velata

Grandispora? macrotuberculata

Grandispora? naumouii cf. naumouii

Perotrilites bifurcatus

Retusotriletes distinctus/cf. distinctus

Retusotriletes rugulatus

Rhabdosporites langii

Tholisporites chulus

Verruciretusispora multituberculata

\section{Chitinozoans}

Alpenachitina eisenacki

Ancyrochitina langei

Angochitina devonica

Angochitina globosa

Angochitina implicationsis

Angochitina mourai

Eisenackitina castor

Hoegishaera glabra
Dalmanites calypso

Humboldtensis

Lichas (Conolichas) eriops

Odontocephalus aegeria

Odontocephalus selenurus

Odontocephalus sp.

Phacops cristata

Proetus crassimarginatus

Proetus crassimarginatus

Terataspis grandis

cf. Dechenella

\section{Rostroconchs}

Hippocardia cunea

Hippocardia ohioense

\section{Stromatoporoids}

Stromatoporella granulata

S. selwyni

S. tuberculatum

S. perannulata

Stictostroma excellens

Appendix 2: Taxa of the Moorehouse Member. Data from Feldman (1980), Klapper (1981) and Oliver (1954).

\section{Brachiopods}

"Chonetes" aff. lineata

"Discina" minuta

"Discina" minuta
Cupularostrum sp. A

Cupularostrum sp. $B$

Cymostrophia patersoni

Cyrtina hamiltonensis
Pentagonia unisulcata Pentamerella arata

Pholidostrophia nacrea

Productella navicella
Corals

Amplexiphyllum hamiltonae

Aulopora sp.

Bethanyphyllum robustum
Conodonts

Polygnathus linguiformis

Polygnathus trigonicus 
"Pacificocoelia" acutiplicata

"Schuchertella" sp.

"Spirifer" duodenarius

"Spirifer" grieri

"Spirifer" macer

"Spirifer" macrus

"Spirifer" raricosta

"Spirifer" varicosa

Acrospirifer duodenaria

Ambocoelia sp.

Ambocoelia umbonata

Amphigenia elongata

Anoplotheca acutiplicata

Athyridacean ident.

Athyris cf. vitata

Athyris sp. A

Athyris sp. $B$

Athyris spiriferoides

Atribonium halli

Atrypa reticularis

Atrypa spinosa

Camarotoechia billingsi

Camarotoechia tethys

Centronella glansfagea

Chonetes deflectus

Chonetes hemisphericus

Chonetes lineatus

Chonetes mucronatus

Coelospira camilla
Cyrtina sp. A

Dalejina aff. alsa

Dalejina sp. A

Discomyorthis? sp.

Elytha fimbriata

Eospiriferid? ident.

Fimbrispirifer bivaricata

Fimbrispirifer divaricatus

Gypidula sp.

Isorthis propinqua

Leptaena rhomboidalis

Leptostrophia perplana

Levenea aff. subcarinata

Levenea lenticularis

Lingula desiderata

Lingula sp.

Megakozlowskiella raricosta

Megastrophia concava

Megastrophia hemisphaerica

Megastrophia sp.

Meristella doris

Meristella nasuta

Meristella sp. A

Meristella? sp. juvs

Meristina nasuta

Mucrospirifer cf. macra

Nucleospira aff. ventricosa

Nucleospira concinna

Paraspirifer acuminatus
Protoleptostrophia perplana

Rhipidomella sp.

Rhynchospirina sp.

Schizophoria cf. multistriata

Schuchertella pandora

Strophalosia? sp.

Stropheodonta demissa

Stropheodonta inequiradiata

Strophonella ampia

\section{Pelecypods}

Aviculopecten ignotus

Cypricardella sp. A

Paracyclas cf. lirata

\section{Trilobites}

"Proetus" sp.

Echinolichas eriopis

Odontocephalus bifidus

Odontocephalus selenurus

Odontocephalus $s p$.

Phacops cristata

Phacops pipa

Phacops sp.

\section{Tentaculitoids}

Hyolithes cf. striatus

Styliolina fissurella

Tentaculites scaleriformis
Blothrophyllum promissum

Breviphrentis yandelli

Ceratopora sp.

Coenites sp.

Cylindrophyllum elongatum

Cystiphylloides americanum

Cystiphylloides sulcatum

Favosites basalticus

Favosites canadensis

Favosites emmonsi

Favosites sp.

Favosites turbinatus

Heliophyllum sp. A

Heterophrentis prolifica

Heterophrentis sp.

Heterophrentis sp. A

Heterophrentis sp. $B$

Heterophrentis sp. $C$

Pleurodictyum convexa

Siphonophrentis gigantea

Synaplophyllum sp. A

Synaptophyllum simcoense

Syringopora $s p$.

\section{Crinoids}

Dolatocrinus marsh

Eutaxocrinus? sp.

Nucleocrinus verneuili

Schultzicrinus? sp.

\section{Gastropods}

"Pleurotomaria" delicatula

"Pleurotomaria" sp.

"Pleurotomaria" sp.

Bellerophon sp.

Coleolus crenatocinctum

Euomphalus cf. clymenoides

Euomphalus decewi

Loxonema sicula

Loxonema sp.

$P$ turbinata

Platyceras carinatum

Platyceras dumosum

Platyceras fornicatum

Platyceras sp.

Platystoma lineatum

Platystoma sp. juvs

Platystoma turbinatum

\section{Cephalopods}

Goldringia citum?

Goldringia trivolvis

Halloceras undulatum

Ovoceras sp.

Striacoceras typum

\section{Sponges}

Hindia sp.

Botryllopora cf. socialis 
Appendix 3: Taxa of the Seneca Member. Data from Feldman (1980) and Schuchert (1943).

\section{Brachiopods}

Pentamerella arata

"Chonetes" aff. lineata

"Spirifer" duodenarius

"Spirifer" grieri?

"Spirifer" varicosus

Anoplotheca acutiplicata

Athyris sp. A

Athyris spiriferoides

Atrypa reticularis

Atrypa spinosa

Camarotoechia billingsi

Camarotoechia tethys

Chonetes deflectus

Chonetes lineatus

Chonetes mucronatus

Chonostrophia reversa

Coelospira camilla

Elytha fimbriata

Isorthis propinqua

Leptaena rhomboidalis

Leptostrophia perplana

Levenia lenticularis

Lingula sp.

Megakozlowskiella raricosta

Megastrophia sp.

Meristella doris

Meristella nasuta

Pentagonia unisulcata

Pentamerella arata

Protoleptostrophia perplana

Schuchertella pandora
Stropheodonta demissa

Stropheodonta inequiradiata

Strophonella ampla

\section{Trilobites}

Odontocephalus selenurus

Phacops cristata

\section{Corals}

Ceratopora sp.

Heterophrentis sp. $B$

\section{Gastropods}

Coleolus crenatocinctum

Platyceras carinatum

Platyceras erectum

Platyostoma lineata

Platyostoma? sp. 
Appendix 4: Taxa from the Eifelian of Ohio. Data from Schuchert (1943), Sparling (1988), Tillman and Murphy (1978), Tillman (1984) and Wicander (1983).

\section{Conodonts}

Marblehead

Polygnathus cooperi cooperi

Icriodus orri

Polygnathus linguiformis bultyncki

Icriodus latericrescens robustus

Polygnathus aff. trigonicus

Polygnathus imatus robustus

Venice

Polygnathus linguiformis linguiformis Icriodus stephensoni

Tortodus kockelianus australis

Polygnathus costatus costatus

Polygnathus aff. trigonicus

Polygnathus pseudofoliatus

Polygnathus linguiformis alingulatus

Delaware

Polygnathus linguiformis linguiformis Icriodus angustus

Polygnathus augustipennatus

Polygnathus intermedius

Prioniodina tortoides

Polygnathus pseudofoliatus

Icriodus stephensoni

Icriodus orri

\section{Pelecypods}

Conocardium cuneus

Glyptodesma erectum
Organic-walled microphytoplankton Tyligmasoma alargadum

Polyedryxium cf. ambitum

Micrhystridium sp. A

Micrhystridium sp. $B$

"Micrhystridium paucispinum"

Pterospermella cf. hermosita

Pterospermella sp.

Dasypilula sp.

Palacanthus ledanoisi

Ozotobrachion furcillatus

Diexallophasis simplex

Cymatiosphaera cornifera

Veryhachium europaeum

Veryhachium trispinosum

Veryhachium pastoris

Veryhachium lairdi

Mulitplicisphaeridium ramusculosum

Hapsidopalla chela

Hapsidopalla exornata

Duvernaysphaera tenuicingulata

Cymatiophaera canadensis

Cymatiophaera sp.

Polyedryxium pharaonis

Polyedryxium bathyaster

Polyedryxium fragosulum

Ozotobrachion dactylos

Pterospermella reticulata

Estiastra rhytidoa

Navifusa bacillum
Hollina sp. aff. labrosa

Exochoderma arca

Dictyotidium variatum

Dictyotidium cohora

Polyedryixium embudum

Arkonites bilixus

Goniolopadium prolixum

\section{Ostracods}

Abditoloculina filaloculina

Abditoloculina pusilla

Abditoloculina quinqueloculina

Abditoloculina repanda

Abditoloculina septiloculina

Abditoloculina sp. (tecnomorphs)

Adelphobolbina papillosa

Aechmina choanobasota

Aechmina longioroidea

Bollia aequitivelata

Bollia obesa

Bollia stewartae

Cornigella sp.

Ctenoloculina elongata

Ctenoloculina platyca

Cubitosulcus typicus

Falsipollex delawarensis

Falsipollex sp.

Flaccivelum directisegmentum

Hibbardia nodosa
Hollina sp. aff. magnilobata

Hollina stewartae

Hollina vegrandis

Jonesites? sp.

Kirkbyella bellipuncta

Kirkbyella stewartae

Marginisulcus vadosus

Parabolbina sp.

Parabolbinoides quinqueportica

Phlyctiscapha rockportensis

\section{Rimabollia bella}

Stictobollia paucifoveata

Subligaculum avitum

Subligaculum proclivisulcatum

Tetrasacculus absindoloculatus

Ulrichia concinna

Ulrichia conradi

\section{Trilobites}

Chasmops calypso

Coronura diurus

Phacops rana

\section{Gastropods}

Euomphalus decewi

Platyceras dumosum

Pleurotomaria lucina

\section{Brachiopods}

Brachyspirifer audaculus

Brachyspirifer macronotus

Camarotoechia prolifica

Camarotoechia sappho

Chonetes coronatus

Chonostrophia reversa

Crispella gregaria

Delthyris consobrina

Delthyris raricosta

Isorthis propinqua

Leiorhychus laura

Leiorhychus limitare

Nucleocrinus verneuili

Paraspirifer acuminatus

Pentamerella arata

Spirifer? divaricatus

Spirifer? macrothyris 
Grammysia bisulcata

Paracyclas ohioensis

\section{Sponges}

Astraeospongia ohioensis
Stellinium octoaster

Murativacea munificus

Induoglobus sp.

Tunisphaeridium tentaculaferum

Gorgonisphaeridium inflatum
Hollina ephippiata

Hollina luxilobota

Hollina rectisegmentata

Hollina senticosa

Hollina sp.
Turbo shumardi

Cephalopods

Gyroceras cyclops 